Universidade de São Paulo

Faculdade de Filosofia, Letras e Ciências Humanas

Departamento de Letras Modernas

Programa de Estudos Linguísticos, Literários e

Tradutológicos em Francês

\title{
Humanismo Satírico em Lima Barreto e Anatole France
}

Versão corrigida

Milene Suzano de Almeida

Tese apresentada ao Programa de Estudos Linguísticos, Literários e Tradutológicos em Francês do Departamento de Letras Modernas da Faculdade de Filosofia, Letras e Ciências Humanas da Universidade de São Paulo, para obtenção do Título de Doutor em Letras.

Orientação: Profa. Dra. Regina Maria Salgado Campos

São Paulo

2013 
Ao meu pai Hélio de Sá Almeida, in memoriam. 


\section{Agradecimentos}

De forma geral, agradeço a todos aqueles que nestes quatro anos deram apoio, direta ou indiretamente, à finalização do texto que agora segue caminho próprio.

Em primeiro lugar, agradeço à minha orientadora, professora Regina Campos, pela confiança depositada em mim para a realização deste trabalho. Agradeço também ao Departamento de Letras Modernas que acolheu o meu projeto e ao Conselho Nacional de Desenvolvimento Científico e Tecnológico (CNPQ) que me ofereceu as condições financeiras necessárias para a sua realização. Agradeço também à Edite Mendes Pi e Valdemiro Júnior pelo auxílio nas questões institucionais.

Na pesquisa realizada na Biblioteca Nacional, agradeço aos préstimos de Anna Naldi, da Divisão de Informação Documental, assim como dos funcionários que, apesar das difíceis condições de trabalho à época, mostraram-se sempre solícitos.

Agradeço ao professor Antonio Arnoni Prado pelo auxílio precioso em todo o andamento da pesquisa, colocando gentilmente à minha disposição materiais bibliográficos de difícil acesso.

Agradeço a todos os amigos que participaram deste processo, às companheiras literárias Marina Bedran e Ludmilla Mendes Lima, à amiga Mariana Chaguri pela leitura sempre atenta e gentil, e aos colegas nas disciplinas que, com seus projetos e dúvidas, também me ajudarm a traçar meu caminho.

Agradeço enfim à minha família, minha mãe Luzia, pelo apoio incondicional; minha filha Isadora, pela sua presença ao meu lado e ao meu marido Eugênio, pelo apoio emocional e intelectual. Sem eles, qualquer tarefa seria muito mais difícil. 
ALMEIDA, Milene Suzano. Humanismo Satírico em Lima Barreto e Anatole France. 2013. 256f. Tese (Doutorado). - Faculdade de Filosofia, Letras e Ciências Humanas, Universidade de São Paulo, São Paulo, 2013.

O presente estudo comparativo buscou traçar os rastros de semelhança na escrita literária do escritor brasileiro Lima Barreto (1881-1922) e do francês Anatole France (1844-1924). A despeito de eventuais diferenças, o que se observou foi um trajeto semelhante no conjunto das duas obras, ancorado numa visão de mundo compartilhada e essencialmente humanista.

Neste trajeto, partiu-se da presença de um novo tipo de herói, o herói intelectual, em grande parte o elemento responsável pelo tom reflexivo e digressivo dos romances e pela redução da esfera da ação nas obras. Nos romances Recordações do Escrivão Isaías Caminha, de 1909, La Rôtisserie de la Reine Pédauque e Les Opinions de M. Jérôme Coignard, de 1893, além da configuração de uma escrita colada aos acontecimentos políticos, sociais e culturais da Belle Époque, observou-se um processo de caricaturização que acompanha a obra de ambos e surge como ponto de partida para o estudo das sátiras Os Bruzundangas, publicado postumamente em 1923, e L'Ille des Pingouins, de 1908. Em meio a este traçado de caricaturização nos romances, observamos ainda a semelhança na trajetória peripatética dos personagens de Jérôme Coignard e Gonzaga de Sá, cujo itinerário se mescla às transformações pelas quais as cidades do Rio de Janeiro e Paris passam.

De forma geral, encontramos nos romances de Lima Barreto e Anatole France uma ironia de aspecto moral e salvacionista que vai, no decurso de alguns romances, colocando em questão a viabilidade deste gênero tão volátil. Diante da intenção corretiva do satirista, o narrador romanesco cede espaço ao modo de imaginação satírica. E no caminho do narrador ao satirista, o herói intelectual vai também perdendo espaço em prol da função última da sátira, de correção de um mundo injusto.

Palavras-chave: Literatura Comparada, Anatole France, Lima Barreto, Ironia, Sátira. 
ALMEIDA, Milene Suzano. Satirical Humanism in Lima Barreto and Anatole France. 2013. 256f. Tese (Doutorado). - Faculdade de Filosofia, Letras e Ciências Humanas, Universidade de São Paulo, São Paulo, 2013.

This comparative study aims to delineate similarity traces between the literary writings of the Brazilian author Lima Barreto (1881-1922) and the French writer Anatole France (1844-1924). Despite eventual variations, we noted a similar path in their works, anchored in a shared worldview, substantially humanist.

To trace this path, we departed from the presence of a new kind of hero, the intellectual hero, which bestows a reflexive and digressive tone to their novels, minimizing the plot. In the novels Recordações do Escrivão Isaías Caminha, from 1909, La Rôtisserie de la Reine Pédauque e Les Opinions de M. Jérôme Coignard, both from 1893, besides setting up a sort of writing attached to the political, social and cultural events of the Belle Époque, we observed a caricaturing process that follows both literary works. This process emerges as the base line to the study of their satire: Lima Barreto's Os Bruzundangas, published posthumously in 1923, and Anatole France's L'Île des Pingouins, from 1908. Along this caricatural process, we also found another similarity, concerning the trajectory of the peripatetic characters of Jérome Coignard and Gonzaga de Sá. Their itinerary is mixed with their cities, Rio de Janeiro e Paris, both in remaking processes.

Generally speaking, we discovered in Lima Barreto and Anatole France's novels a kind of moral and rescuer irony that, during some of their novels, questions the feasability of this changeable literary genre. Against the corrective intention of the satirist, the novel storyteller gives way to the satiric mode of imagination. And in the path from the storyteller to the satirist, the intellectual hero also loses his significance to the ultimate function of satire, the correction of an unfair world.

Keywords: Comparative Literature, Anatole France, Lima Barreto, Irony, Satire. 


\section{Résumé}

ALMEIDA, Milene Suzano. L'Humanisme satirique chez Lima Barreto et Anatole France. 2013. 256f. Tese (Doutorado). - Faculdade de Filosofia, Letras e Ciências Humanas, Universidade de São Paulo, São Paulo, 2013.

Dans cette étude comparative, nous avons essayé d'indiquer les ressemblances entre la production littéraire de l'écrivain brésilien Lima Barreto (1881-1922) et le français Anatole France (1844-1924). Malgré quelques variations, nous avons trouvé un chemin pareil dans l'ensemble de leurs oeuvres. Ce chemin est centré sur un même regard sur le monde, un regard essentiellement humaniste.

De ce point de vue, nous avons commencé par la proposition d'un nouveau type de héros, le héros intellectuel. En grande partie, ce héros apporte des digressions et un ton réflexif aux romans de ces deux écrivains, ainsi comme une réduction de l'action dans leurs oeuvres. Au-delà d'une écriture serrée aux évènements politiques, sociaux et culturels de la Belle Époque, dans les romans Recordações do Escrivão Isaías Caminha, de 1909, La Rôtisserie de la Reine Pédauque et Les Opinions de M. Jérôme Coignard, de 1893, nous avons trouvé un processus caricatural qui les accompagne, constituant en même temps le point de départ pour l'étude des satires Os Bruzundangas, publié en 1923, après la mort de Lima Barreto, et L'Île des Pingouins, de 1908. Le long de ce trajet caricatural que nous avons découvert dans les romans, nous avons trouvé aussi une ressemblance entre les parcours péripatétiques des deux personnages, Jérôme Coignard et Gonzaga de Sá, dont l'itinéraire se mêle aux villes en travaux de Rio de Janeiro et Paris.

En général, nous avons trouvé dans les romans de Lima Barreto et Anatole France, un type d'ironie morale et salvatrice que, au cours de quelques romans, tient en échec la validité d'un genre aussi changeant que le roman. Vis-à-vis du projet correctif $\mathrm{du}$ satiriste, le narrateur du roman recule devant le mode d'imagination satirique. Et dans ce chemin du narrateur au satiriste, le héros intellectuel s'affaiblit face à l'ultime fonction de la satire, la correction d'un monde injuste.

Mots-clés: Littérature Comparée, Anatole France, Lima Barreto, Ironie, Satire. 


\section{Anatole France}

DJS - Les désirs de Jean Servien

RRP - La Rôtisserie de la reine Pédauque

OJC - Les Opinions de M. Jérôme Coignard

OM - L'Orme du mail

MO - Le manequin d'osier

AA - L'anneau d'améthyste

MBP - M. Bergeret à Paris (1901)

PN - Pierre Nozière

IP - L'Île des pingouins

$\mathrm{Cr}$ - Crainquebille

JE - Le Jardin d'Épicure

LR - Les Lys rouge

CSB - Le Crime de Sylvestre Bonnard

Le Livre - Le Livre de mon amie (1885)

SPB - Sur la Pierre Blanche (1905)

\section{Lima Barreto}

IC - Recordações do escrivão Isaías Caminha

HS - Histórias e Sonhos

TC1 - Toda Crônica, volume 1

TC2 - Toda Crônica, volume 2

PS - Prosa Seleta

Coleção Brasiliense (1956):

IC - Recordações do escrivão Isaías Caminha (v. I)

PQ - Triste fim de Policarpo Quaresma (v. II)

GS - Vida e Morte de M. J. Gonzaga de Sá (v. IV)

HS - Histórias e Sonhos (v. VI)

Bru - Os Bruzundangas (v. VII)

CRJ - Coisas do reino do Jambon (v. VIII)

Bag - Bagatelas (v. IX)

FM - Feiras e Mafuás (v. X)

VU - Vida Urbana (v. XI)

Marg - Marginália (v. XII)

IL - Impressões de Leitura (v. XIII)

CAP1 - Correspondência ativa e passiva, tomo I (v. XVI)

CAP2 - Correspondência ativa e passiva, tomo II (v. XVII)

${ }^{1}$ Optamos por usar as siglas para facilitar a citação de trechos das obras. Nas referências no corpo do texto, indicaremos a obra de acordo com essas siglas, o ano de publicação e a página. 
RÉSUMÉ

SIGLAS

SUMÁRIO 8

APROXIMAÇÕES 10

PARTE 1: PARATEXTOS 22

1. AMBIÊNCIA 23

2. HeRói INTELECTUAL 42

O percurso de SeRVIen e o descolamento de Caminha 45

CRIADOR E CRIATURA 48

ROMANCES TOLSTOÍSTAS

52

3. "POÉTICA" 60

PARTE 2 : ROMANCES 71

1. UM LEITOR-MODELO 72

PEQUeNA E GRANDE HISTÓRIA 78

NARRADORES-ENGANADORES 81

NOTA SOBRE RECORDAÇÕES DO ESCRIVÃo ISAÍAS CAMINHA 84

2. O JORNALÍSTICO 93

PASTICHE MELODRAMÁTICO E ELIMINAÇÃO DA INTRIGA 99 


\section{O POÉTICO}

"LE JARDIN SECRET"

SONHOS UTÓPICOS E ESTRUTURA REFLEXIVA

LA Cité et la VILle

RESÍDUO CARICATURAL

4. O MORALISTA

O EXótico e o caricatuRAL EM BeRgeret E GonZAga de SÁ

Os TRUBLIONS E A ESCOLA DE JAVA

IDEALIDADES POSSÍVEIS

1. o SAtírico

SORRISO MELANCÓLICO

VISADA SATÍRICA 176

MÉTOdo de JULGAMENTO 181

CONTEXTO DE PUBLICAÇÃO 185

LOCAL E UNIVERSAL

2. humanismo Satirico

ESTÓRIAS EXEMPLARES

L'AFFAIRE DES QUATRE-VINGT MILLE BOTTES DE FOIN

O MUNDO FUTURO

O HUMANISMO SATÍRICO 


\section{Aproximações}

"Les martyrs manquent d'ironie et c'est là un défaut impardonnable, car sans l'ironie le monde serait comme une forêt sans oiseaux; l'ironie c'est la gaieté de la réflexion et la joie de la sagesse." (Anatole

France)

"Rio, 18-5-1909.

Querido Antônio.

Recebi hoje a tua carta e o teu cartão. Vieram no mesmo paquête e chegaram aqui com o Anatole France. O Veríssimo, o Medeiros e os insuportáveis estudantes (não estava o Lacerda) consagraram-no a valer. O barão convidou-o a almoçar no Itamarati e a academia deu uma sessão em honra a êle. O Rui falou, falou com aquela pretensão e aquela falta de visão que lhe são peculiares, durante hora e tanto, tentando fazer crítica à obra do Jérôme Coignard ou Sylvestre Bonnard, como quiseres. Disse que era vice-presidente do Senado e se batia pela paz universal. [...] Como já está consagrado, o grande homem andou aqui, pelas ruas, em procissão, acompanhado de repórteres, de fotógrafos, tôda essa raça vil e bêsta de Gasparonis e Castelares. E assim passou êle e eu não o vi, nem de longe." (CAP1, 1956, p. 75)

"Certa noite, estava France, em companhia de Veríssimo e outros paredros da Academia, fazendo um passeio pela Avenida, quanto teve a atenção atraída pelo cinema que o Pascoal Segreto instalara ao lado do seu cabaret, em frente à Americana. Dirigia-se para lá, quando do grupo escandalizado partiu a advertência de que se tratava de um cinema livre. Anatole deu a ombros, e entrou. Os filmes - diga-o quem uma vez assistiu a essas exibições - eram tão horrendos na sua abjeção canalha, que mais pareciam cartazes de propaganda contra o perigo das moléstias venéreas. France, que aceitava tudo por princípio de ética, sorria. E Lima Barreto, ao me contar o episódio, ria, ria muito, não de Anatole, mas do Veríssimo e do cortejo que, transido de vergonha, se via forçado a participar da incontinência do Mestre ..." (Barbosa, 2012, p. 217) 
Os dois trechos acima dizem respeito à visita de Anatole France ao Brasil em 1909. Na primeira, Lima Barreto escreve ao amigo Antônio Noronha dos Santos comentando a passagem do "grande homem" pelas ruas do Rio de Janeiro. Na segunda, é Noronha dos Santos que reproduz as palavras de Barreto zombando da reação dos acompanhantes de France ao interesse do escritor francês pelo "cinema livre". Os dois trechos trazem à tona duas facetas de Lima Barreto: o ponto de vista crítico em relação aos seus contemporâneos e o tom d'anecdote e trocista por meio do qual ele descreve os acontecimentos. São estes dois aspectos, curiosamente, que o aproximaram de Anatole France, diferentemente de seus pares, que viam no criador de Sylvestre Bonnard somente o sensualista da "ironie et pitié".

Anatole France, nascido em 16 de abril de 1844 em Paris e falecido na mesma cidade em 12 de outubro de 1924 foi, para Afonso Henrique de Lima Barreto, nascido 40 anos depois, em 13 de maio de 1881 , e falecido dois anos antes, em $1^{\circ}$ de novembro de 1922, um escritor militante. Leitura peculiar de um escritor admirado por aqui como o sensualista, de linguagem límpida, parnasiano. Talvez porque Anatole France foi um pouco de tudo: parnasiano, dreyfusard, socialista? Talvez porque Barreto tinha uma forma peculiar de leitura? Talvez uma forma de Barreto se opor aos seus pares e desafetos? Estas são as primeiras perguntas que vêm à mente ao aproximarmos dois autores tão distantes, ao mesmo tempo tão próximos. Pois é desta relação que trataremos aqui, dos pontos de contato entre as duas obras, de Barreto e France, e entre duas formas de estar no mundo destes dois homens que viveram intensamente suas épocas, seus meios literários, suas cidades.

De origem simples, Anatole France viveu sua infância e juventude em meio aos livros do sebo de seu pai. A consagração literária, desacreditada pelo pai, foi conquistada na eleição para a Academia Francesa de Letras, em 1896. Mas, uma reviravolta iria alterar a sua carreira literária, os acontecimentos do "affaire Dreyfus", caso que dividiu a França nos últimos anos do século XIX. Num clima de pós-guerra com a Alemanha, o capitão judeu, Alfred Dreyfus, foi condenado injustamente por crime de traição à pátria em fins de 1894. O caso, porém, só adquiriu a dimensão que conhecemos hoje com a publicação, em 13 de janeiro de 1898, de J'accuse, carta aberta de Émile Zola ao presidente da República, Félix Faure, em defesa de Dreyfus. É a partir deste momento que a França se divide em dois campos de batalha: os dreyfusards, partidários da revisão do processo contra Dreyfus e os antidreyfusards, preocupados 
antes de tudo com a segurança do Estado, mesmo que ao custo de uma injustiça. A despeito da posição confortável que ocupava no mundo das letras, Anatole France se opôs à grande maioria de seus pares que acreditava na culpabilidade do capitão judeu e apoiou a revisão do processo. Apoiou Zola, quando este publicou o libelo no jornal l'Aurore e devolveu sua Légion d'Honneur, quando a mesma foi retirada de Zola, que foi processado, condenado e exilou-se na Inglaterra. Foi, dizendo o mínimo, um homem de pensamento crítico e independente.

Anatole France seria novamente consagrado em 1921 com o Prêmio Nobel pelo romance Le Crime de Sylvestre Bonnard² (CSB), de 1881. Gunner Ahlström (1963), num texto de admirador exaltado, conta a história da premiação e a ida do já octogenário escritor para as terras frias da Suécia. O nome de Anatole France já havia sido proposto anteriormente em 1904, 1910 e 1916, mas a sua figura contraditória provocava nos membros da academia sueca algumas ressalvas. Em 1904, o relatório do Dr. Wirsén dizia: "Há nos seus escárnios, no gelo de seus sarcasmos, algo de estéril, de desesperador até ...” (Ahlström, 1963, p. 12). A desconfiança em relação a France tenderia a aumentar com a sua adesão ao socialismo e com o apoio às causas revolucionárias na Rússia. Mesmo assim, com o aval de três suecos, ele ganhou o prêmio em 1921, deixando para trás nomes como os de Bernard Shaw, H.G. Wells, W. Yeats e Henri Bergson.

Lima Barreto não chegou perto da consagração do escritor francês ${ }^{3}$, apesar das sucessivas e frustradas candidaturas à Academia Brasileira de Letras ${ }^{4}$. Carregou desde o

\footnotetext{
${ }^{2}$ Este romance foi anunciado pela Bibliographie de la France em abril de 1881, mas o texto desta edição foi bastante modificado em 1902. Em uma nova edição de 1922, France corrigiria ainda algumas disparidades cronológicas. Pierre Frondaie fez uma peça em três atos do romance, representada em 1916 e em 1931. A obra também foi adaptada para o cinema pelo diretor André Berthomieu. Essas e outras informações sobre boa parte das obras de Anatole France estão disponíveis nas notas da edição da Bibliothèque de la Pléiade [Gallimard, 1984; 1987; 1991; 1994], organizada pela crítica Marie-Claire Banquart.

${ }^{3}$ Em uma introdução ao livro de Coelho Neto, José Maurício Gomes de Almeida discorda dessa posição, pelo menos no que se refere à recepção da obra de Barreto posterior à sua morte em 1922. Diz o prefaciador de $O$ Morto (1898) que o "prestígio quase mítico" que cercava a figura de Lima Barreto nos anos 1930 foi uma das razões do ostracismo de Coelho Neto. De fato, Coelho Neto foi um escritor muito criticado por Barreto como representante das forças literárias mais tradicionais, porém, não é consenso que o prestígio do criador de Policarpo Quaresma tenha contribuído para tal situação. Ver Coelho Neto (1994).

${ }^{4}$ Lima Barreto se candidatou três vezes a uma vaga na Academia. Em 1917, ele enviou uma carta a Rui Barbosa informando de sua candidatura à vaga de Sousa Bandeira. Porém, essa primeira candidatura nem foi considerada, por não ter sido apresentada dentro dos cânones acadêmicos. Em 1919, Barreto concorreu para a vaga de Emílio de Meneses tendo tido alguns poucos votos e, segundo Barbosa, contado com o apoio de João Ribeiro e Afonso Celso. A última tentativa foi em 1921, mas Barreto acabou desistindo por motivos pessoais.
} 
início até o final da vida a pecha de escritor maldito e marginal. Também de origem humilde, viu o mundo das letras como um outsider e fez da sua palavra uma arma de batalha. Apesar de buscar a consagração literária, haja vista o insistente desejo de se tornar um imortal, o custo de seu inconformismo parece ter sido mais alto, pois logo no momento em que debutava no mundo das letras, escolheu para romance de estreia, Recordações do escrivão Isaías Caminha ${ }^{5}(\mathrm{IC})$, de 1909, obra na qual atacava exatamente aqueles que poderiam lhe dar um primeiro acesso ao Olimpo Literário: a imprensa. Além disso, sua curta carreira literária foi interrompida primeiramente pela loucura do pai que impediu a continuidade dos estudos do jovem escritor, e, em seguida, pelas internações do próprio autor no hospício, em função do alcoolismo. Como poderiam trajetórias tão distintas, apesar da origem humilde de ambos, traduzirem-se em semelhanças? Uma das chaves de comparação é a posição de passagem ou de transição de ambos. Enquanto Lima Barreto é classificado como um pré-modernista, Anatole France, segundo o crítico francês, Albert Thibaudet, pelo seu estilo, pelas suas paródias, cadências e imitações, “... a posé un curieux point final, provisoirement final, à la littérature classique" (Thibaudet, 2007, p. 457).

Nesta posição limiar entre movimentos literários, os dois autores nos parecem confrontar a visão do novo e a permanência do velho. Antonio Arnoni Prado (1974; $1989^{6}$ ) examinou a trajetória da atitude crítica em Lima Barreto, desde como se formou a posição crítica do escritor em face da literatura oficial de sua época e até que ponto essa atitude abalou as bases de uma literatura em transição para o moderno. Prado escapa da interpretação corrente que vê em Barreto somente um autor no qual se chocam o novo e o velho e segue no exame mais profícuo das direções, alcances e limites do seu inconformismo, examinando toda a obra do autor de 1904 até a sua morte

${ }^{5} \mathrm{O}$ romance As recordações do escrivão Isaías Caminha teve sua primeira parte publicada na revista Floreal em 1907. As duas edições publicadas ainda durante a vida do autor foram a da Livraria Classica Editora de Portugal, de 1909 e a da Azevedo \& Costa Editores, de 1917, com prefácio recuperado da Floreal. Há ainda a edição de 1956, volume I da coleção da Brasiliense. Encontramos inúmeras edições da obra, como: de 1943 pelo Livro de Bôlso, de 1949 pela Mérito, de 1966 pelo Clube do Livro, de 1990 pela Ática, de 1997 pela Ediouro e Publifolha, de 2002 pela Rideel, de 2004 pela Companhia Nacional, de 2005 pela Germape, de 2007 pela Escala, e de 2010 pela Martin Claret e Penguin/Companhia das Letras. Utilizamos essa última no presente trabalho. A sigla das citações será IC e usaremos a forma simplificada Isaías Caminha para nos referirmos ao romance.

${ }^{6}$ No texto de qualificação, utilizamos a edição de 1976. Para a escrita da tese, só conseguimos a edição revisada de 1989 ao final do período de escrita. Essa edição incorpora pesquisas posteriores de Prado que tiveram o intuito de recompor as afinidades intelectuais de Lima Barreto na sua filiação ideológica à esquerda, com os anarquistas, e à direita, com as elites e literatos. A filiação a Anatole France recupera de certa maneira essas dualidades. Durante o texto, utilizamos mais a edição de 1976, porém, nas conclusões, incorporamos os elementos desenvolvidos no texto de 1989, para melhor situal as contribuições do presente estudo comparativo para a investigação das dualidades limabarretianas. 
em 1922. No encalço desse inconformismo, o crítico apontou elementos importantes como o abalo da mímesis pelo uso caricatural da linguagem ou a denúncia do falseamento do real no rebuscamento dos literatos brasileiros. Ao fim, porém, chega à conclusão de que seu protesto se dá pela exclusão e não pela consciência história da ordem em crise; isso porque ao lado do radicalismo de seu projeto estético, Prado percebe uma utopia do projeto político. Toda a análise do crítico, com outras minúcias, acompanhará a nossa compreensão da obra limabarretiana. Ao final, porém, buscaremos apontar algumas outras possibilidades para a interpretação do projeto político do autor, à luz das comparações desenvolvidas no correr da tese.

As primeiras buscas na direção dessa aproximação já foram realizadas anteriormente. O sociólogo Sergio Miceli aproximou Anatole France e Lima Barreto no seu "estudo clínico dos anatolianos", de 1977, grupo estruturado a partir do que o sociólogo chamou de "protótipo dos anatolianos" : “... aquele para cujo êxito têm o mesmo peso a figura do 'dândi', [...] e uma obra poética que registra 'estados d'alma', ambos os planos marcados pela contrafacção dos modelos parisienses" (Miceli, 1977, p. 77) $)^{8}$. Para Miceli, “criador" e obra estariam ligados de tal forma nos anatolianos que o sucesso literário seria equivalente ao mundanismo do autor-criador. Ainda que algumas das características apresentadas por Miceli sejam de fato comuns entre Barreto e France, como é o caso do ofício público ou do trabalho nos jornais ${ }^{9}$, a ideia de handicap social e a sugestão do mundanismo e do dandismo parecem-nos questionáveis no que diz respeito a ambos. O que se vê nessa relação é uma adesão, de um lado, à interpretação de France como o "bon chic, bon genre", o tradicionalista burguês marcado pela crítica surrealista, e, de outro, a visão de Barreto como um escritor menor na história literária brasileira.

Posição diferente aparece no retrato da Belle Époque tropical para o historiador americano Jeffrey Needell (1993). Para Needell, France e Barreto estão dispostos em polos opostos na configuração do mundo literário da época. Ao construir um quadro do

${ }^{7}$ Os anatolianos, segundo Miceli, são: Humberto de Campos Véras, Afonso Henrique de Lima Barreto, Jonathas Archanjo da Silveira Serrano, Hermes Floro Bartolomeu Martins de Araújo Fontes, Vivaldo Coaracy, Manuel Carneiro de Souza Bandeira, Paulo Setúbal, Gilberto de Lima Azevedo Souza Ferreira Amado de Faria e José Maria Bello.

${ }^{8}$ No quadro dos anatolianos, formado a partir de informações biográficas, apenas dois escritores nos são familiares hoje, o próprio Lima Barreto e o poeta Manuel Bandeira.

${ }^{9}$ France trabalhou na biblioteca do Senado e Barreto foi amanuense no Ministério da Guerra. Quanto ao trabalho nos jornais, é importante lembrar que grande parte da atividade de Barreto nos jornais deu-se nos pequenos e desconhecidos periódicos da sua época, diferentemente de France, que publicou nos grandes veículos da imprensa francesa. 
mundo literário da Belle Époque carioca, Needell opõe Barreto a escritores como Olavo Bilac, Coelho Neto, João do Rio, Elísio de Carvalho e Afrânio Peixoto - aos quais ele atribui a influência mais forte de Anatole France -, e o situa como um crítico destes círculos sociais, juntamente com Euclides da Cunha, Silvio Romero e José Veríssimo. Essa configuração proposta pelo historiador americano é também um retrato da primazia da recepção de France parnasiano, sensualista, em nada semelhante à leitura limabarretiana. Ainda assim, esse quadro sugere a necessidade de um olhar mais arguto sobre o momento literário brasileiro e francês.

Seguindo com algumas modificações o mapa literário de Needel, o historiador Nicolau Sevcenko (2003) estuda a relação entre as obras de Barreto e Euclides da Cunha. Porém, ainda que o foco do historiador seja esta relação específica, logo nas primeiras páginas do livro, Sevcenko sugere a aproximação entre Lima Barreto e Anatole France. Para ele, Barreto é, no Brasil, quem melhor realiza a "ironia redentora" do escritor francês. A obra limabarretiana é construída, para Sevcenko, como um espaço de resistência à literatura da Belle Époque, literatura esta identificável por um "repertório limitado de clichês", ao qual sucumbem também o público e a crítica.

Seguindo a mesma linha do inconformismo de Prado, Barreto, juntamente com Euclides da Cunha, incorporaria a resistência na literatura pré-modernista, ainda que escritores de gerações anteriores, como o crítico José Veríssimo, já tivessem iniciado essa vertente. O historiador atribui a Veríssimo a filiação a um viés irônico diferente do machadiano: “... à ironia amarga e cética de Machado de Assis, Veríssimo prefere aquela de cunho social e reforçadora da solidariedade humana, como em Anatole France, e que encontraria o seu melhor realizador no Brasil em Lima Barreto." (Sevcenko, 2003, p. 124).

A oposição à escritura machadiana por Barreto é um dos aspectos levantados por Carlos Nelson Coutinho, que situa a relevância da obra de Lima Barreto frente ao "formalismo parnasiano que domina quase inteiramente o romance brasileiro da época imediatamente pós-machadiana" (Coutinho, 1974, p. 17). Barreto se posicionaria, segundo Coutinho, em oposição ao distanciamento superior de Machado de Assis, à perspectiva subjetivista dos românticos e ao ambiente determinante dos naturalistas, trazendo para o centro de sua obra a ênfase no desajuste entre a realidade social e o 
mundo estético tradicional das letras ${ }^{10}$. Seguindo esse viés mais ideológico da relação, a aproximação entre Liev Tolstoi e Lima Barreto por Robert Oakley (2011) parece sugestiva. Nela, o crítico inglês parte da concepção de arte desenvolvida na conferência de Mirassol ${ }^{11}$, uma espécie de manifesto literário do escritor brasileiro. São nos textos escritos ao final da vida que Tolstoi desenvolve a concepção de arte utilizada por Barreto no texto de Mirassol. Para Tolstoi, a arte é "une forme de l'activité humaine consistant, pour un homme, a transmettre à autrui ses sentiments [...] il est un moyen d'union parmi les hommes, les rassemblant dans un même sentiment" (Tolstoi, 1918, p. $58)^{12}$. Esse poder de contágio é apontado por Barreto no texto de Mirassol, para quem a arte literária se apresentaria com “... um verdadeiro poder de contágio que a faz facilmente passar de simples capricho individual, para traço de união, em força de ligação entre os homens" (IL, 1956, p. 62). Essa força de ligação concorreria para a concretização de uma harmonia entre os homens, "orientada para um ideal imenso em que se soldem as almas, $[\ldots]$ como semelhantes no sofrimento da imensa dor de serem humano"13.

Apesar da forte ligação ao texto de Tolstoi, proporemos aqui que o viés humano e idealista de Barreto tem sua origem, em grande parte, na literatura militante de France. Neste mesmo texto de Mirassol, inclusive, o escritor francês aparece citado duas vezes. $\mathrm{Na}$ primeira alusão, há um gracejo sobre a beleza física necessária ao conferencista e Barreto comenta que “... em Anatole, achamos eu e alguns amigos um belo homem; mas não da beleza que fere as mulheres" (IL, 1956, p. 52). A beleza, mais do que a consistência de ideias, é o que concederia o sucesso ao gênero, segundo o irônico Lima Barreto. Na segunda alusão, ele cita o conto Crainquebille como grande obra, ao lado de outras como Dom Quixote e As Viagens de Gulliver. Veremos mais detalhadamente a

${ }^{10}$ Tratando do folhetim "O Subterrâneo do Morro do Castelo", publicado em 1905 no Correio da Manhã, Beatriz Resende marca esse rompimento com os padrões parnasianos na escrita limabarretiana acompanhado pela preocupação social e política e o desejo de ser a voz dos segregados. Ver Barreto (1997).

${ }^{11}$ Lima Barreto foi para Mirassol a convide de Ranulfo Prata que, vendo a condição degradante do amigo, busca retirá-lo do Rio de Janeiro em 1921. Os amigos de Prata promovem uma conferência de Barreto em Rio Preto, mas, apesar de escrevê-la, Barreto desaparece e é encontrado bêbado por Prata. O texto foi publicado na Revista Sousa Cruz e depois na coletânea Impressões de leitura, volume XIII das obras completas (1956).

12 Consultamos primeiramente a edição da Penguin, porém vimos que não havia ali o texto completo, somente os capítulos V e XV da obra completa, sem nenhuma explicação do porquê da seleção dos capítulos. Passamos a utilizar então a edição francesa de 1918.

${ }^{13}$ Quando não repetirmos o número da página e a fonte, considerar a referência imediatamente anterior. 
leitura de Tolstoi por Barreto, problematizando a apropriação e interpretação do escritor brasileiro. Também Anatole France escreve sobre Tolstoi e se corresponde com o escritor, muito provavelmente levado pelo seu apreço pelos movimentos revolucionários russos. A leitura particular do russo por France também será objeto de análise a partir da coletânea de textos reunidos em Vers les temps meilleurs (VTM) ${ }^{14}$.

Além do texto de Mirassol, são recorrentes as referências de Barreto a France, seja ao autor, à obra ou a suas personagens. France aparecia na Limana ${ }^{15}$ com as obras Le Lys Rouge (1885), Pierre Nozière (1899), Crainquebille e Au Petit Bonheur. Porém, a despeito de serem as únicas na biblioteca particular, muitas referências aos personagens ou situações da obra de France fogem ao escopo da "limana anatoliana". O conto Crainquebille, foi apreciado não somente por Barreto, mas também por modernistas como Oswald de Andrade que o definiu como "conto social". O poeta Carlos Drummond de Andrade também revelou sua forte ligação com Anatole France, criticada pelo modernista Mário de Andrade ${ }^{16}$. De fato, havia uma mania anatoliana naquele período. Augusto Meyer falaria alguns anos depois do anatolismo da época, uma moda, uma coqueluche de seu tempo, curiosamente descrita pelo escritor:

"Todo mundo usava então no cocoruto das idéias um barrete de vovô irônico; mal o amigo mais escanhoado abria a boca para falar, cresciathe do queixo uma barbicha de fauno, e deslizavam todas as frases com uma cautela fofa de pantufas pisando em tapete. Meninos de quinze anos, ainda cheirando a cueiros, lançavam sobre o vasto mundo um olhar desiludido e, entre dois gestos displicentes, citavam Pirro; senhoras respeitáveis, pondo uma insídia de serpe nas suas graças maduronas, aludiam discretamente ao Jardim de Epicuro, esse evangelho da ironia e da piedade." (Meyer, 1956, p. 98).

Certamente, não foi essa leitura corrente de Anatole France que atraiu a atenção de Lima Barreto. De qualquer maneira, ingressar neste anatolismo do período significa desvendar um período da história literária no Brasil, período esse repleto de polaridades, debates, ideologias, utopias. É este o trabalho que nos propomos aqui, um mergulho no anatolismo peculiar de Lima Barreto. Pois se o anatolismo fosse somente uma moda, será que Barreto, o grande inimigo do senso comum e das ideias prontas, haveria de

\footnotetext{
${ }^{14}$ Trata-se de uma coletânea em quatro volumes com os textos de intervenção de Anatole France, organizada por Claude Aveline (VTM1, 1949; VTM2, 1953; VTM3, 1963; VTM4, 1973).

15 Trata-se da coleção de livros catalogados por Lima Barreto e descrita na biografia de Francisco de Assis Barbosa (1959; 2012). Consultamos primeiramente a edição de 1959; porém, durante a escrita da tese, foi publicada uma nova edição revisada.

${ }^{16}$ Ver Gledson (2003)
} 
segui-la? O que o atraia em Anatole France? Certamente, a faceta militante de ambas as obras. Mas como ela se configura? Quais as suas peculiaridades?

Para nos aproximarmos um pouco mais do projeto literário de ambos, a proposição da figura do herói intelectual por Robert Oakley, particularmente do personagem-narrador errante de Vida e Morte de Gonzaga de Sá (GS), de $1919^{17}$, foi de grande valia. Oakley compara Machado ao personagem anatoliano do Monsieur Bergeret, figura central na série Histoire Contemporaine ${ }^{18}$. O crítico ressalta o tipo de "trajetória peripatética" explorada pelo escritor francês e, segundo ele, semelhante ao modelo do romance limabarretiano. Essa relação entre os dois personagens é a que mais se aproxima de um procedimento propriamente literário no quadro das influências e relações propostas até aqui.

\section{$* * * *$}

A tese está dividida em três partes.

$\mathrm{Na}$ primeira, dividida em três capítulos, abordaremos aspectos mais genéricos e contextuais do estudo comparativo. No primeiro capítulo, buscaremos traçar algumas linhas gerais do mapa literário do Rio de Janeiro e de Paris à luz da relação entre Lima Barreto e Anatole France. Na Belle Époque e na Belle Époque tropical, o intuito inicial é recuperar os debates correntes à época em que France e Barreto estiveram diretamente ligados às respectivas produções literárias locais. A intenção deste capítulo é, mais do que compor um quadro estático, estabelecer a complexidade de cada contexto e apontar diálogos possíveis entre os ambientes literários e culturais de Paris e Rio de Janeiro.

No segundo capítulo da primeira parte, trataremos da configuração do herói intelectual a partir do livro de Victor Brombert (1961). Para Brombert, o século XX na França foi invadido por uma geração de intelectuais diretamente ligados à crise do humanismo e da ciência, herdeira do legado de Hippolyte Taine e Ernest Renan. Essa experiência foi filtrada pelos romancistas que deram aos seus heróis uma figuração na qual as ideias, os debates e as ideologias estiveram à frente da ação ou do enredo. Num

${ }^{17}$ Esse romance sai primeiramente na Revista do Brasil, de 1919, lançada no mesmo ano pela Editôra Mérito, edição acrescida de contos. Além da edição da Brasiliense, de 1956, volume IV, há ainda uma de 1943 da editora O livro de Bolso, uma de 1986 da Ediouro, uma de 1990, da Garnier e outra de 1997 (classificado como infanto-juvenil) da editora Ática. A sigla das citações será GS e usaremos a forma simplificada Gonzaga de Sá para nos referirmos ao romance.

${ }^{18}$ Série em de quatro volumes: L'Orme du mail (OM, 1897), Le Mannequin d'osier (MO, 1897), L'Anneau d'améthyste (AA, 1899) e M. Bergeret à Paris (MBP, 1901), todos eles compostos de coletâneas de textos publicados na imprensa por France em meio aos acontecimentos do caso Dreyfus. 
contexto de alta escolaridade e de grandes paixões ideológicas, o herói intelectual será abordado aqui a partir de dois romances, Les Désirs de Jean Servien ${ }^{19}$ (DJS), de 1882 e Isaías Caminha.

Enfim, no último capítulo desta parte inicial, trataremos do estatuto dos prefácios como parte integrante das obras e como texto síntese de uma "poética" particular. No caso de Lima Barreto e Anatole France, as velhas regras poéticas cedem espaço para um projeto humanista, no qual encontramos muito mais regras éticas de composição do que propriamente elementos estilísticos ou regras de gênero a serem seguidas. Mais do que subverter a forma dos romances, a intenção destes narradores é, principalmente, a comunicação com o leitor.

$\mathrm{Na}$ segunda parte, partiremos para o exame dos romances em quatro direções. Primeiramente, na fixação do lugar de Barreto como leitor-ideal da obra anatoliana, seguida de uma breve digressão acerca da interpretação corrente de Isaías Caminha. Em seguida, trataremos do aspecto jornalístico no romance de estreia de Barreto e em dois romances anatolianos protagonizados pelo personagem do abade Jérôme Coignard, $L a$ Rôtisserie de la reine Pédauque ${ }^{20}$ (RRP) e Les Opinions de M. Jérôme Coignard $^{21}(\mathrm{OJC})$. No terceiro capítulo desta segunda parte, abrimos espaço para a poesia das obras na relação muito próxima que se forma entre os personagens dos romances de Gonzaga de Sá e na série do senhor Bergeret com as suas respectivas cidades. Estes dois "irmãos literários”, como sugere Amoroso Lima, travam com as cidades do Rio de Janeiro e Paris uma relação de profunda simbiose. Por fim, no último capítulo, retomaremos o percurso da literatura militante, particularmente no que algumas das narrativas de Lima Barreto e Anatole France apresentam como concepção moral do mundo.

${ }^{19} \mathrm{O}$ romance foi publicado pela editora Lemerre em abril de 1882, precedido de um prefácio suprimido por France em 1898, na quinta edição, em função da crítica aí contida a Émile Zola. A Calmann-Lévy edita o romance a partir de 1907. Nas referências, utilizaremos a sigla DJS e simplificaremos o título para Jean Servien.

${ }^{20}$ Encontramos uma tradução dessa obra no Brasil pela editora Vecchi, de 1947, intitulada $A$ Rotisseria da Rainha Pedauque. Quanto à sua publicação na França, os capítulos saíram primeiramente em folhetim em L'Écho de Paris de outubro a dezembro de 1892, editados em volume depois pela Calmann-Lévy em 21 de março de 1893, com reedição em 1921. Consultamos a edição da Pléiade (Gallimard, 1987). Utilizaremos o título reduzido Rôtisserie ao tratar da obra. A sigla da obra usada nas citações é RRP.

${ }^{21}$ Não encontramos nenhuma tradução desse romance para o português. A obra foi publicada inicialmente em folhetim em L'Écho de Paris e em Le Temps e a edição original pela Calmann-Lévy saiu em outubro de 1893. Uma nova edição corrigida foi publicada em 1923. A sigla nas referências é OJC e consta no mesmo volume de Rôtisserie. Usaremos a redução Opinions para tratar da obra. 
Os dois últimos capítulos desta segunda parte, "O Poético" e "O Moralista", podem ser lidos como complementares, pois muitos dos assuntos tratados no primeiro são retomados no segundo, sob outra perspectiva. Neste último, buscaremos dar prosseguimento ao estudo do elemento caricatural nos romances de Bergeret e Coignard, no ensejo de traçar a linha que foi iniciada nos dois primeiros capítulos desta segunda parte, enquanto no primeiro, proporemos uma digressão na configuração do que chamamos de Humanismo Satírico, exatamente como um entreato ou intervalo teatral, um momento de pausa na construção do nosso objeto, mas necessário para sutilizar a análise.

$\mathrm{Na}$ última parte da tese, concentraremos as atenções no objeto de análise inicial deste trabalho: as sátiras. Dividida em dois capítulos, essa parte final buscará integrar o que foi desenvolvido anteriormente, concluindo uma espécie de linha satírica que se vislumbra em vários momentos das obras de Anatole France e Lima Barreto. Mais do que um gênero, a sátira nos parece ser um caminho encontrado na literatura para traçar um retrato do mundo pela literatura, sem se isentar da participação ativa na vida social de seu tempo. $O$ humanismo satírico se configurará, ao final, como um olhar particular para a arte e para vida de dois autores que nunca se eximiram do difícil papel de homens públicos e artistas.

Alguns pontos nortearão a nossa busca. Em primeiro lugar, uma compreensão do tipo de ironia que aparece na obra dos dois autores e que Sevcenko designou "ironia redentora". Em segundo lugar, a problematização da leitura que Lima Barreto faz de Anatole France como um escritor militante, opondo-se à leitura corrente do escritor francês no Brasil. Em terceiro lugar, a opção pela literatura nos dois autores envolve uma compreensão particular de escrita, na qual os processos satíricos vão colocando em questão a viabilidade do romance como gênero possível para uma literatura militante. Neste quadro de satirização, a própria presença do herói intelectual será questionada, já que a função de corrigir um mundo injusto irá se sobrepor à criação literária.

Por fim, considero fundamental um breve testemunho do percurso de trabalho que resultou nesta tese. No projeto inicial de doutorado, constavam duas epígrafes que poderiam representar o ponto de partida deste trabalho. Na primeira, o narrador de L'Île des Pingouins $^{22}$ (IP) dizia: "Une pratique constante de l'Église contribua sans doute à maintenir cette heureuse communion des fidèles: on brûlait immédiatement tout Pingouin qui pensait

${ }^{22}$ As crônicas que compõem a sátira dos pinguins saem primeiramente no New York Herald, de 1905 a 1907, com diferentes títulos. A edição completa do livro com o título de L'Ŷle des Pingouins sai publicada um ano depois, em 1908, pela Calmann-Lévy. Faz parte do volume IV da Pléiade. 
autremente que les autres" (IP, 1994, p. 133). Na segunda, temos o narrador de Os Bruzundangas $^{23}$ (Bru) afirmando que: "Um país como Bruzundanga precisava ter os seus heróis e as suas heroínas para justificar aos olhos do seu povo a existência fácil e opulenta das facções que a têm dirigido." (Bru, 1956, p. 90). Na primeira citação, o anticlerical fervoroso Anatole France transfere para o mundo dos pinguins uma das lutas que travou durante sua vida, pela separação definitiva entre Estado e Religião. Na segunda, o satirista Lima Barreto usa toda a verve de sua crítica à estrutura social injusta deste simulacro do Brasil. Em ambos, a busca por uma linguagem artística capaz de denunciar e corrigir o real, de uma escrita em sintonia com o seu tempo e pautada pelos assuntos mais relevantes de seu contexto.

Foram estes dois satíricos, críticos de suas respectivas sociedades, a inspiração inicial da tese. A partir deste primeiro ambiente de similitudes, o trabalho se voltou para a leitura das obras de France e Barreto, no intuito de observar outros pontos de contato entre as obras e aprofundar o conhecimento de cada um deles particularmente. Esta fase de leituras dos romances, contos e outros textos de intervenção - complementada pelas disciplinas cursadas no primeiro ano de doutorado - foi fundamental para traçar o percurso satírico que foi se construindo na interpretação destas duas obras em estudo comparativo. A partir do exame de qualificação, em novembro de 2011, como sugestão da banca, incorporei ao trabalho novos elementos dos contextos literário, político e social destes dois escritores, com a finalidade de ancorar as questões levantadas com a leitura das obras na sua concretude. Este estudo contextual reestruturou toda a pesquisa, uma vez que colocou em movimento uma gama de escritores, debates, contextos, semelhanças e dissonâncias. A estrutura da tese é resultado desta movimentação contextual de um primeiro embate textual. O humanismo satírico é o resultado desta movimentação entre obra e contexto de produção. De um lado, uma forma de ver o mundo, de outro, uma forma de representá-lo.

${ }^{23}$ Publicado postumamente pelo editor Jacinto Ribeiro dos Santos em 1923, tem uma segunda edição em 1930. Consta ainda uma edição da Mérito, de 1952 e a da Brasiliense, volume VII das obras completas, de 1956 e 1961. Há ainda edições pela Ediouro, Ática, LPM, DCL, Fortaleza e Martin Claret. Consultamos a edição da Prosa Seleta (Editora Nova Fronteira), a edição de bolso da LPM e a da Brasiliense, de 1956. As primeiras crônicas sobre a República das Bruzundangas são publicadas em 1911 na Gazeta da Tarde com o título Império das Bruzundangas. Porém, a maioria dos textos aparece em 1917, no semanário A.B.C., sob o título de República dos Estados Unidos da Bruzundanga. O prefácio é de setembro deste mesmo ano. 


\section{Parte 1: Paratextos}

"On a beau chercher, on ne trouve jamais que soi-même” (Anatole France)

A começar por Anatole France, a grande literatura tem sido militante. (Lima Barreto) 


\section{Ambiência}

Ao tratar de um autor ou de uma obra literária, é fundamental recompor a sua ambiência. No caso da literatura comparada, o estudo desse meio de produção exige alguns esforços extras do pesquisador. Como se não fosse amplo suficiente o escopo de tratar de dois universos literários, a pesquisa nessa área não pode prescindir de um olhar, ainda que breve, sobre o universo social e político do qual deseja se aproximar. A amplitude dos estudos literários sempre foi, inclusive, uma das grandes críticas a essa disciplina literária sem método próprio, excessivamente abrangente, mas, talvez por todas as dificuldades, sempre instigante e certamente imprescindível.

De fato, os estudos de literatura comparada estão em crise desde os primeiros anos do século $\mathrm{XX}^{24}$. Mas, foi somente em sua conferência no $2^{\circ}$ Congresso da ICLA (International Comparative Literature Association), de 1958, que René Wellek se referiu à primeira grande crise da literatura comparada. Wellek propôs naquele ano, em oposição à concepção factualista e positivista de um dos iniciadores do que fícou conhecido como "escola francesa", Paul Van Tieghem, e ao novo humanismo ingênuo de Fernand Baldensperger, uma reorientação nos estudos de literatura comparada, cujo foco retornaria ao problema da "literariedade" abandonada, segundo ele, por uma motivação ligada ao nacionalismo cultural e por um conceito mecanicista de fontes e influências. Esse foi só o início de longos debates que até hoje se fazem relevantes no âmbito da literatura comparada, e o objeto de estudo escolhido para essa tese, certamente, não foge a todas as questões colocadas na polêmica história da disciplina.

No caso da relação entre Lima Barreto e Anatole France, as referências explícitas de Barreto ao escritor francês não tornam mais fácil a tarefa crítica e comparativa. Isso porque, apesar da relação aparecer sugerida não só pelo autor brasileiro como por críticos, os dois escritores se distanciam não somente do ponto de vista geográfico, como também geracional. Em função dessa situação de partida para os estudos, não poderíamos nos furtar ao exame mais detalhado de seus respectivos

\footnotetext{
${ }^{24}$ Os franceses Claude Pichois e André Rousseau marcaram o nascimento da disciplina por volta de 1830, tendo como eventos decisivos um curso de Abel François Villemain em 1828 e o primeiro curso oficial de "literatura comparada" ministrado na Sorbonne por Jean-Jacques Ampère. Esse como os outros textos aqui citados acerca da literatura comparada foram traduzidos e publicados na coletânea de Coutinho \& Carvalhal (2011).
} 
ambientes literários, até mesmo porque, como já vimos, o historiador Jeffrey Needel, ao propor um quadro da Belle Époque carioca, situa Barreto e France em lados opostos no mapa de influências e grupos literários do período. Também no andamento do trabalho essa retomada se mostrou fundamental, mesmo após o início dos estudos dos elementos textuais de semelhança encontrados nos romances, contos e nas crônicas de ambos. $\mathrm{O}$ exame isolado dos procedimentos revelou-se, na ausência de uma contextualização mais ampla, um tanto ingênuo e parafrástico.

Dois motivos concorrentes podem ser elencados na problematização dessa dupla contextualização: de um lado, e apesar da inquestionável presença francesa no Brasil, estamos tratando de diferentes gerações: France nasceu em 1844 e viveu até 1924, enquanto Barreto nasceu em 1881, falecendo em 1922; de outro, as trajetórias desses dois escritores não podiam ser mais distantes: da França, temos aquele que foi lembrado como o símbolo do tradicionalismo, principalmente em função da crítica dos surrealistas $^{25}$; do Brasil, trata-se do escritor rebelde, mulato e louco. Essa classificação reducionista, porém, nos parece construída a partir de pontos de vista estagnados. Isso acontece, muito provavelmente, devido ao reduzido estudo desse momento da vida literária nacional que não seja pela lente dos escritores consagrados. Porém, a despeito das dissonâncias entre os dois autores e de uma certa aura mística, positiva ou negativa, criada em torno deles, a crítica brasileira não deixou de apontar, em diferentes momentos, algumas semelhanças entre estes dois autores, como na ironia redentora de Nicolau Sevcenko ou nos anatolianos de Sérgio Miceli.

Comecemos então pelo lado francês dessa relação. Anatole France começou a publicar seus primeiros artigos na imprensa num momento no qual a censura imposta pelo Segundo Império, de Napoleão III, ainda se fazia presente. Foi nas revistas eruditas que os textos do jovem escritor começaram a ser publicados, revistas mais tradicionais e intelectualizadas que acabavam aceitando artigos de teor mais liberal: "sous pretexte de rendre compte d'un livre, on y exprimait tout ce que l'Empire interdisait" (Bancquart, 1984a, p. 60). Foi nessa mesma década que o escritor começou a frequentar o grupo dos parnasianos, tendo auxiliado na preparação do primeiro volume de poemas do grupo, o primeiro Parnasse Contemporain, tornando-se editor do terceiro volume, em 1876. A seleção das obras para o terceiro Parnasse rendeu a France algumas célebres inimizades

${ }^{25}$ Em 1924, os surrealistas publicaram um texto coletivo, Le cadavre, no qual celebram a morte de Anatole France, representante, segundo eles, da tradição francesa mais deplorável. 
que seriam definitivas para a recepção de sua obra póstuma ${ }^{26}$. A despeito da crítica e do esquecimento póstumos, esse filho do livreiro Noël France alcançou em vida não somente a consagração literária, como influenciou fortemente a sua geração, não somente na França como em muitos outros países pelo mundo, dentre eles certamente o Brasil.

O círculo dos parnasianos, meio no qual France iniciou sua carreira literária, era formado por escritores mais velhos, como Leconte de Liste e Louis Ménard, e pelo grupo dos vinte e poucos anos, dentre eles Sully-Prudhomme, Hérédia, François Coppée, Mallarmé, Verlaine e o próprio France. Apesar de se agruparem sob o rótulo parnasiano, as divergências entre os membros eram muitas. Diante do primor técnico compartilhado pelo grupo, os escritores parnasianos oscilavam do mais completo refúgio literário ao ativismo político. Um dos mais velhos escritores do grupo, Leconte de Lisle, fora um quarante-huitard e se desesperou com o Segundo Império, refugiando-se "dans une antiquité pleine de grandeur" (Bancquart, 1984a, p. 61). Coppée, como outros mais jovens, não aceitou a reclusão e resignação, e escolheu falar da atualidade, ainda que fazendo uso de temas da antiguidade como pretexto para suas alusões antigovernamentais.

Esse foi também o caminho percorrido por France, que se ligou a Louis-Xavier Ricard, um dos escritores mais militantes do grupo, com quem ele concebeu o projeto de uma Encyclopédie de la Révolution ${ }^{27}$. Estamos, porém, ainda muito longe do escritor engajado do caso Dreyfus, pois ainda eram muito tênues o radicalismo e o republicanismo anatoliano no seu período parnasiano. $\mathrm{O}$ radicalismo anatoliano estava restrito até esse momento aos limites da liberdade de expressão para o exercício do pensamento e da reflexão; um engajamento livresco, poder-se-ia dizer.

No período parnasiano, paralelamente aos artigos na imprensa, France publicou também duas coletâneas de poemas. Em 1873, Les Poèmes Dorés, e em 1876, Les

${ }^{26}$ Ele foi o algoz da rejeição dos versos apresentados por Stéphane Mallarmé e Paul Verlaine, alegando, em suma, a obscuridade dos poemas. Ainda que tenha escrito outros textos elogiosos a ambos posteriormente, na sua coluna La vie littéraire, no jornal Le Temps, Paul Valéry, em nome dos antecessores rejeitados, não chegou nem mesmo a citar o nome de France na sua posse na Academia de Letras, em 1925, exatamente para a vaga do criador de Sylvestre Bonnard.

${ }^{27}$ Há uma alusão a um projeto grandioso e frustrado do mesmo tipo no romance autobiográfico Le Livre de mon amie (Le Livre), de 1885. O romance foi publicado em jornais e revistas entre $1879 \mathrm{e}$ 1885, saindo pela Calmann-Lévy em março de 1885. Fora anteriormente anunciado no L'Univers Illustré, de novembro de 1884 com o título Les Aventures de Pierre Noziére. Uma nova edição revisada pelo autor foi publicada em 1901. A experiência frustrada de France no grupo dos parnasianos pode ter inspirado a metáfora de Teutobochus, título de um dos capítulos do livro. 
Noces Corinthiennes, um "poème scénique violemment antichrétien", nas palavras de Bancquart $^{28}$. Não nos ateremos nesse estudo à obra poética do autor, mas ela é fundamental no que diz respeito à utilização de um procedimento literário compartilhado pelo grupo dos parnasianos e que se tornaria um elemento chave na obra de France: a incorporação de temas e textos antigos na narrativa em prosa. A despeito da pouca relevância de sua produção em verso, foi a publicação de Les Noces Corinthiennes e a coluna no jornal Le Temps que marcaram o início da ascensão literária do autor que, a partir de então, ingressa definitivamente no mundo literário, envolvendo-se nas querelas literárias da época e também recebendo apoios de autores consagrados como George Sand e Hypollite Taine ${ }^{29}$.

As agitações políticas ainda estavam longe de estar no centro de suas preocupações. A vida nos salões, o casamento com Valérie Guérin de Sauville em 1877, o nascimento de sua filha Suzanne em 1881; todos esses acontecimentos, juntamente com o sucesso financeiro e o crescente acesso aos círculos literários da época, fortemente marcados pelas soirées nos salões, fazem parte dos passos iniciais rumo à ascensão de Anatole France. No mesmo ano do nascimento de sua filha, foi publicado o romance Le Crime de Sylvestre Bonnard. Mesmo que ainda não se possa perceber nesta obra o tom político e social, já é possível ver nesse primeiro romance não somente a presença das querelas literárias, como dos debates científicos da época: “... elle va contre les présupposés de la littérature naturaliste: confiance en la science, description sans concession de tristesses, des platitudes, des misères sociales” (Bancquart, 1984a, p. 115). Aparece também aqui outro elemento constitutivo da sua obra, as "marcas da piedade anatoliana", uma espécie de simpatia autoral resultante de uma percepção aguçada da miséria humana, marca definidora da ironia redentora sugerida por Sevcenko. Em 1882, sai publicado o romance Les Désirs de Jean Servien, segundo Bancquart, mais doloroso e amargo que os anteriores, percepção também enfatizada por Maurice Barrès, escritor pouco mais jovem que France, cuja obra é marcada pelo forte conteúdo nacionalista:

Il réveille en moi l'admirable et précieuse tristesse de l'Éducation sentimentale. Il y a là une sincérité poignante, je ne sais quel air autobiographique, une âpreté qui n'est que la réalité, tout un ensemble enfin qui en feront, si je ne me trompe, le bréviaire de plus d'un de

${ }^{28}$ Denise Fraga (2007) lembra ainda de Idylles et légendes. Nenhuma destas obras poéticas figura na edição da Pléiade.

${ }^{29}$ As querelas literárias e os detalhes desse período estão em Bancquart (1984a;1994a). 
nos contemporains. (Barrès apud Bancquart, 1984a, p. 119).

Servien é, como Frederic Moreau, um personagem em formação e sua trajetória pode ser lida como uma espécie de síntese de uma geração que transita entre uma origem burguesa simplória e os desejos de grandeza despertados pela convivência com as classes mais altas. Mas, mais do que uma educação sentimental, o que torna o personagem de Jean Servien interessante do ponto de vista narrativo é o seu processo de educação intelectual que traduz numa nova crise do herói romanesco, uma crise deflagrada pela mundança de status cultural e social de uma geração. Esse aspecto geracional está intimamente ligado ao contexto de desencanto desse fim de século. Diante de uma República frágil e de um país ressentido com a perda da guerra para a Alemanha em 1870, a democratização educacional e a incorporação de novos quadros nos grupos sociais de elite nos parecem ser de extrema importância.

Passando para o outro lado do Atlântico, não há como negar a enorme influência francesa no Brasil de fins do século XIX e começo do século $\mathrm{XX}^{30}$. Mas como se deu tal relação? Cópia ou interpretação? Conteudismo ou esvaziamento? Uma interpretação interessante foi proposta por Brito Broca a partir das reformas nas cidades de Paris e do Rio de Janeiro. Broca ressalta a diferença de conteúdo entre as obras do Barão Haussmann e as do prefeito Pereira Passos:

Haussmann remodelou Paris, tendo em vista objetivos políticomilitares, dando aos bulevares um traçado estratégico, a fim de evitar as barricadas das revoluções liberais de 1830 e 48; enquanto o plano de Pereira Passos se orientava pelos fins exclusivamente progressistas de emprestar ao Rio uma fisionomia parisiense, um aspecto de cidade europeia. (Brito Broca, 1960, p. 3).

Broca ressalta aqui não somente uma defasagem, como um esvaziamento de sentido entre o projeto francês e o brasileiro. Mais do que isso, enfatiza o caráter imagético da reforma de Passos que teria por fim somente um embelezamento. Arriscando transpor esse efeito de embelezamento para o universo literário, e ciente da crítica que tanto marcou a obra de Barreto dessa disparidade entre o real e a imagem do real, teria a recepção de Anatole France como o sensualista da ironia e piedade encoberto qualquer outro tipo de interpretação diferenciada? Não teria sido a leitura

${ }^{30}$ Dentre as muitas referências que tratam dessa relação, podemos citar alguns livros: Culturas cruzadas: intercâmbios culturais entre França e Brasil, de Mário Carelli, e Encontro entre literaturas: França-Brasil-Portugal, de Pierre Rivas. Além de outros estudos mais problematizadores da relação: os textos "De cortiço a cortiço", de Antonio Candido, "Galofilia e galofobia na cultura brasileira", de Leyla Perrone-Moisés; além do livro de Jeffrey D. Needell já referido anteriormente. Recentemente foi lançado o livro Cinco séculos de presença francesa no Brasil: invasões, missões, irrupções, organizado por Leyla Perrone-Moisés. 
inusitada de France como escritor militiante, segundo Lima Barreto, possível exatamente pelo olhar flagrante do criador de Isaías Caminha do descolamento entre o real e o ideal? Nesse sentido, não seriam Isaías e Servien, heróis e vítimas de uma mesma geração de indivíduos que se situam sempre hors et là, entre a conformidade e a rebeldia, entre a militância e a consagração, como bem interpretou Bancquart (1994a) acerca da posição de Anatole France? ${ }^{31}$

O que Broca interpreta como defasagem e esvaziamento de sentido na transposição do projeto de remodelação das cidades de Paris para o Rio de Janeiro explicaria também a visão estagnada da influência anatoliana sensualista no Brasil, que deixou de lado o aspecto crítico e flagrante de um escritor que se manteve questionador de si mesmo e do mundo no decorrer da longa carreira. A interpretação de France por Barreto como autor militante permite-nos pensar numa redefinição desse momento da literatura, pois ao se opor à interpretação de seus contemporâneos acerca desse autor que foi uma das grandes influências francesas no Brasil do início do século XX, Barreto toca na mesma tecla que Broca, na denúncia do esvaziamento dos cenários e dos tipos que são transpostos para um Rio de Janeiro imaginário, muito diferente daquele que ele via là, nos subúrbios cariocas. Essa realidade sobreposta artificialmente está no cerne da crítica limabarretiana, cuja perspectiva se opõe aos grandes da literatura carioca, assim como nos parece ser central na recepção do "anatolismo".

Dentre os grandes literatos criticados por Barreto está Afrânio Peixoto, autor de A Esfinge, de $1911^{32}$. O livro foi escrito durante uma estadia de três meses nas imediações do Cairo, inspiração que dá o tom a obra. Nela, Peixoto narra a história de uma relação amorosa entre o pintor Paulo e Lúcia, associando os descompassos da história de amor ao enigma da esfinge. O roman à clef de Peixoto, escritor que Needell situa do lado anatoliano, teve grande sucesso no seu lançamento, em oposição ao romance de estreia de Barreto, também classificado na mesma categoria à clef pela crítica $^{33}$. O romance de Peixoto foi duramente criticado por Barreto, que o achou “detestável”, segundo Barbosa (1959; 2012); particularmente indignado com o rótulo 1912.

${ }^{31}$ Veremos este aspecto no decorrer do texto, mas principalmente no capítulo "O Jornalístico".

${ }^{32}$ Até a edição consultada, de 1978, foram 12 edições do livro e uma tradução espanhola em

${ }^{33}$ Broca afirma que o romance de Peixoto foi o terceiro best-seller brasileiro, ficando atrás somente de Canãa, de Graça Aranha, e Os Sertões, de Euclides da Cunha. Mas, diferentemente desses dois, A Esfinge dava ao público a experiência de um "êxito mundano" marcado pelo "sorriso da sociedade" do autor. 
negativo de roman à clef dado ao seu romance de estreia e com a ausência de reprimenda à mesma categorização de $A$ Esfinge.

O que mais revoltou Barreto foi, segundo seu biógrafo, a rotulação de Isaías Caminha num artigo de Medeiros e Albuquerque. Para ele, o rótulo de roman à clef representava uma restrição à sua obra. Anos depois, porém, Barreto defenderia o gênero associando-o à literatura militante: "Para êle, o gênero não implicaria em nenhuma inferioridade literária, mas uma forma de literatura militante”. (Barbosa, 1959, p. 183). Em dezembro de 1921, a questão ainda estava latente e, em um artigo publicado no periódico A.B.C, um comentário de Barreto ao romance $O$ Homem sem máscara, de Vinício da Veiga, o autor de Isaías Caminha defenderia que a força desse tipo de romance estaria na descrição do tipo e não somente no uso de simples "pseudônimos transparentes" 34 . Essa orientação direcionada à tipificação dos personagens, fortemente relacionado ao encobrimento do real, sem deixar de apontá-lo, também aparecerá na obra de Anatole France.

O retrato que Brito Broca (1960) realizou do início do século XX no Brasil enfatizou a boêmia como um espaço privilegiado do mundo literário. Segundo o crítico, Barreto viveu num período no qual a boemia dos cafés dera lugar à boemia dourada dos salões, a jeunesse dorée de João do Rio, seguindo o padrão francês. De um lado, os parnasianos do grupo de Coelho Neto, de outro, os decadentistas da juventude dourada. A Barreto, avesso a todo tipo de figurações literárias descoladas da realidade do país, restavam os pequenos círculos boêmios e a oposição sarcástica ao grupo da geração precedente. Diogo de Castro Oliveira (2008) examinou os grupos da boemia literária da geração anterior a Barreto e contemporânea a France no final do século carioca. Compostos, entre outros, por figuras como Coelho Neto e Olavo Bilac, estes grupos viveram as grandes mudanças na cidade do Rio com a prefeitura de Pereira Passos, na "turbulenta última década do século, década de ajustes e repressões, sempre sob o imperativo da ordem e a tutela do Estado" (Oliveira, D 2008, p. 24). De um lado, é essa a geração a qual Needell atribui a influência de Anatole France sensualista e parnasiano, de outro é a geração contra a qual Barreto se opõe mais ferozmente.

Sobre essa boêmia carioca da geração do fim do século, D. Oliveira aponta para a descontinuidade entre a produção literária e a "modernidade" nos escritores brasileiros

34 Texto intitulado Um Livro desabusado, publicado em 24 de dezembro de 1921 e reunido posteriormente na coletânea Impressões de Leitura (IL), volume XIII da edição de 1956 da Brasiliense. 
do período - nas obras carregadas de um estilo castiço e bacharelesco, como em $A$ Conquista, de Coelho Neto, de 1897. Esta descontinuidade resulta num movimento bem distante de uma modernidade crítica em sintonia com os movimentos mundanos da cidade em transformação. Diante dessa "modernidade" que não se configura artisticamente, D. Oliveira observa a trajetória do grupo consagrado no período de produção de Lima Barreto. Para ele, a forma mental desses boêmios, saturada de projeções, estaria na origem ideológica de um processo de incorporação que iria dos patafísicos, os que estariam "fora dos hábitos e do conformismo do pensamento" (Oliveira, D, 2008, p. 69), aos onosarquistas, metáfora da centralidade medíocre a partir da figura do burro, termo criado por Gonzaga Duque em Mocidade morta, romance de 1899.

Essa passagem da oposição à incorporação ideológica, na qual o engajamento dos escritores esmorecia gradativamente, opõe-se ao que se observa na trajetória anatoliana. Ainda que consagrado em vida e muito lido pelas gerações contemporâneas no Brasil, France não se absteve das querelas e debates de sua geração, em geral, opondo-se cada vez mais aos seus pares e às injustiças sociais. Quanto a Barreto, não resta dúvida sobre a sua posição diante dessa geração parnasiana e decadentista: o seu olhar crítico está presente em toda a sua obra. O fato é que nos primeiros anos do século XX, quando Barreto inicia sua carreira, esse grupo de boêmios, antes insubmissos, já se acomodara ao poder, como se acomodaria ironicamente o personagem de Isaías Caminha. Neste misto de acomodação e insubmissão, começam a convergir os projetos de France e Barreto.

Um retrato da boêmia insubmissa em fins do século XIX e acomodada no século XX no Brasil aparece em Mocidade morta. Nesse romance, o grupo dos "Insubmissos", o Zut $!^{35}$, é apresentado pelo narrador como a representação de uma geração que fez da boemia uma forma de se contrapor à arte oficial, mas que, paulatinamente, vai se conformando com o fracasso; processo descrito como inexorável diante da não aceitação das regras de reconhecimento artístico. Esse destino trágico da geração escolhida por Duque já está marcada no título do romance, nessa mocidade que não se

${ }^{35}$ Segundo Vera Lins (1997), esse grupo era inspirado nos "zutistes", grupo francês criado em 1883 por Charles Cros. Para Lins, Gonzaga Duque e o grupo dos simbolistas tinha uma visão trágica dos tempos modernos em oposição à visada otimista da modernidade. Nesse "tempos eufóricos", Duque e também Barreto, na sua escrita militante, faziam oposição ao discurso oficial, seja pelo hermetismo da linguagem, seja pelo ataque a figuras e situações da República. 
realiza. Segundo Antonio Arnoni Prado, o que se passa no romance de Gonzaga Duque é a:

“... representação de um conflito de gerações na vida intelectual brasileira, quando, por volta de 1895 , acirram-se as diferenças entre alguns jovens intelectuais e os medalhões da época, em querela que se alastrou a partir do chamado "movimento dos Novos"'. (Prado, 2004, p. 20).

Escrito num estilo castiço e rebuscado, em muitos momentos lembrando um tipo de decadismo francês à la Huysmans, Duque não deixa de se mostrar irônico em relação ao ambiente enfatuado dos nossos 1900, como na adoração ao pintor Telésforo de Andrade, que "resvalava, pela inconsciência cognominativa, para o estortego do ridículo" (Gonzaga Duque, 1995, p. 25). A ironia aparece muitas vezes também como autocrítica, como na preocupação exagerada com as vestimentas dentro do grupo dos insubmissos, seja em Camilo Prado, "um anêmico escanifrado com ares de fidalguia abastardada", seja em Artur de Almeida, "muito orgulhoso num colarinho novo e tão alto que lhe impedia o movimento do oval lamartiniano da cabeça" (Gonzaga Duque, 1995, p. 17). Esse componente crítico e pessimista é o que distingue Mocidade morta de A Conquista, e provavelmente o que chamou a atenção de Barreto, já que ambos tratam da boêmia carioca, ainda que em épocas distintas. Duque observa a decadência onde Coelho Neto vê o processo de consagração literária.

O romance de Duque, narrado em terceira pessoa, se passa no ambiente fluminense dos artistas-pintores nos últimos anos de 1880. O jornalista e crítico Camilo Prado e o pintor Agrário de Miranda dividem o papel central na narrativa. O primeiro é

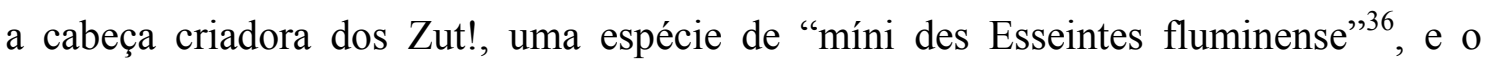
segundo é quem dá nome ao grupo. O destino dos dois homens, construídos em oposição pelo narrador, é um flagrante de uma ordem social, política e artística que resiste a modificações estruturais. Enquanto Agrário vai para a Europa e lá encontra espaço em meio aos representantes mais tradicionais da arte pictórica francesa: "ele frequentava o atelier Gerôme, mas pretendia outro mestre e até o fim seria possível que se passasse para o Cormon ou o Rochegrosse ...” (Gonzaga Duque, 1995, p. 216) ${ }^{37}$, Camilo, depois de sucessivos fracassos, e decepcionado com o rumo dos

\footnotetext{
${ }^{36}$ Definição de Alexandre Eulálio a partir do personagem central do romance de Huysmans, que veremos à frente. A observação de Eulálio está no posfácio da edição consultada de Mocidade morta.

37 Segundo nota da bem cuidada edição de 1995, trata-se de Jean-Léon Gerôme, pintor academicista; Fernand Cormon, inimigo da pintura impressionista; e Georges Rochegrosse, pintor de temas históricos.
} 
acontecimentos, acaba morrendo solitário nas ruas da cidade. O desfecho do romance anula qualquer perspectiva idealista ou de transformação: o único caminho de sobrevivência artística é a incorporação à tradição.

Duque terminou a obra em 1897, mas só veio a público dois anos depois. No mesmo ano, foi publicado o romance $A$ Conquista, de Coelho Neto, segundo Alexandre Eulálio, "nos antípodas do romance de Gonzaga Duque". Segundo Eulálio, "a sedutora euforia humorística de $A$ Conquista contrastava até pelo estilo, ali bastante despojado e transparente, com a densidade patética da ficção de Gonzaga Duque" (Eulálio apud Gonzaga Duque, 1995, p. 293). Segundo Prado, porém, esses dois romances, dos insubmissos de Duque e dos boêmios de Coelho Neto, são "representantes de um momento de esplendor parnasiano, tocados todos pela mesma estupefação ante o cotidiano avassalador que mudava aspirações e exigia atitudes" (Prado, 2004, p. 17). Do ponto de vista da distância em relação ao real, os romances de Gonzaga Duque e Coelho Neto sofrem da mesma patologia que seria denunciada por Barreto, na esteira do bovarismo. Mesmo que os personagens passem pelas tribulações da boêmia, eles são retratados com um "sofrimento engrandecedor". A vida nas ruas, o sofrimento dos menos abastados e as contradições de nossa modernidade aparecem apenas como motivo poético, nunca como proposição estética de ruptura com o estilo decadentista ou parnasiano.

A Conquista é um romance de memórias no qual Coelho Neto, a partir do personagem Anselmo, conta as dificuldades da vida boêmia de um escritor no Rio de Janeiro do final do século XIX, particularmente nos momentos que antecedem ao fim da escravidão. No prefácio o autor dedica o livro aos seus amigos e diz que sua intenção era "contar aos que surgem a odysséa da nossa sociedade". A inspiração no Oriente e nos gregos marca o jovem escritor que se opõe no livro não somente ao naturalismo de seu mestre e amigo Ruy Vaz, um dos pseudônimos usados por Aluísio Azevedo, mas à linguagem bacharelesca das escolas de Direito. As declarações de amor ao oriente se repetem por todo o romance, assim como a idealização do sofrimento boêmio, do cotidiano e das ruas, estas últimas descritas nos moldes do parnasianismo mais piegas, a "delambida rameira" Sete de Setembro, a "maltrapilha e zambra" rua da Conceição, ou a rua Haddock Lobo, "com o seu ar repousado e feliz de velha senhora abastada" (Coelho Neto, 1913, p. 87). Enquanto o exotismo de Coelho Neto está na inspiração 
oriental, no caso de Duque a excentricidade reside no uso rebuscado da linguagem. Ambos, de uma forma ou outra, nos parecem buscar alhures a inspiração narrativa.

Essa idealização do exótico é encontrada no mesmo período no meio literário francês. Os anos de 1885 a 1890 foram na França palco da voga do misticismo, do decadentismo. Paul Bourget qualificou o sentimento dominante como "une nausée universelle devant les insuffisances de ce monde" (Bancquart, 1984a, p. 162). O uso de drogas, as nevroses, a necessidade de um retorno às fontes do sagrado, tudo isso era corrente no fim de século francês. Como no caso do romance À Rebours, de Joris-Karl Huysmans, de 1884, que causou polêmica desde a sua recepção na França, e até hoje é uma leitura das mais inusitadas. O personagem do jovem des Esseintes, que concentra em si toda a narrativa, é uma espécie de Fréderic Moreau excêntrico. Juntamente à linguagem fortemente opaca e metafórica, o romance de Huysmans é certamente um contraponto à escrita límpida de Anatole France.

$\mathrm{Na}$ mesma linha do excêntrico, porém de inspiração cristã, inscreve-se o romance Le Desesperé, de Léon Bloy, publicado em 1887. Trata-se de um manifesto cristão, anti-naturalista, anti-cientificista, uma "literatura do desespero", como classifica o próprio autor. Nele, é narrada a história de Caïn Marchenoir, escritor pobre que busca na religião a salvação para a sua mísera existência. Com uma riqueza de imagens e um texto fortemente metafórico, o livro nos parece ter sido bastante influenciado pela escrita de Huysmans. Os personagens do romance são inspirados em figuras da época, e o próprio Bloy revela a lista de equivalências em cartas escritas no ano da publicação ${ }^{38}$. Assim como o livro de Huysmans, trata-se de um romance perturbador, com imagens fortíssimas como o flagelo que Véronique, amante de Marchenoir, infringe a si mesma, arrancando seus próprios dentes, na intenção de parecer menos desejável ao perturbado companheiro, para ajudá-lo a não cair no pecado da carne.

O também religioso Paul Bourget, que é um personagem no romance de Bloy ${ }^{39}$, publica Le Disciple, em 1889. No mesmo ano, o editor da Revue des Deux-Mondes, Ferdinand Brunetière, escreve para a RDM um texto elogioso ao livro de Bourget, ao

\footnotetext{
${ }^{38}$ A edição consultada, de 2010, da Flammarion, traz além da descrição dos personagens e seus equivalentes, documentos como os esboços e fontes da obra.

${ }^{39}$ Bourget é Alexis Delaurier no romance, escritor consagrado ao qual Marchenoir escreve uma carta pedindo auxílio financeiro logo no início do romance. Nas notas do romance, o organizador, Pierre Glaudes, conta que Bloy conheceu e se tornou amigo de Bourget em 1876, mas que em 1885 eles romperam a relação de amizade.
} 
mesmo tempo em que começa a ser publicado ali o romance Thaïs ${ }^{40}$, de Anatole France, com alguns cortes feitos a pedido do editor Brunetière.

O romance de Bourget teve um enorme sucesso, com cerca de 22 mil exemplares vendidos nas primeiras seis semanas depois da publicação. Nele, Bourget narra a história do cientista Adrien Sixte, inspirado em Taine, e do seu discípulo Robert Greslou, que, utilizando-se da teoria científica do mestre, empreende um experimento amoroso com a jovem Charlotte, filha do marquês de Jussat, na casa onde Greslou passa a habitar como professor do filho mais novo, Lucien. O caso de amor acaba em catástrofe com o suicídio da moça e Greslou é acusado pela morte de Charlotte. Por orgulho, o discípulo de Sixte só revela o que de fato acontecera ao mestre, por meio de uma carta. Ele sabe, porém, que o conde André, irmão da moça, conhece os pormenores do caso, pois Charlotte lhe enviara antes de morrer, uma carta revelando os acontecimentos. Greslou não precisa se defender, pois o conde André o inocenta. Para defender a honra da família, porém, André mata Greslou. Mais do que uma trágica história de amor, trata-se de um "roman à idées", como o próprio Bourget definiu sua obra. O prefácio, intitulado $\dot{A}$ un jeune homme, tem de fato um tom de manifesto direcionado à vida moral dos jovens franceses. $\mathrm{O}$ debate sobre a responsabilidade moral do cientista diante da ação de seus discípulos já vinha de longa data, uma crítica que se dirigia particularmente contra o discurso científico e racionalista.

Anatole France entra no debate defendendo o livre pensamento e criticando o determinismo de Bourget. Essa rivalidade com Brunetière e Bourget será fundamental para a mudança de posição de France em relação aos seus pares. O debate movimentou o mundo literário francês e fícou conhecido como a "querelle du Disciple". Ele colocava de lados opostos, de fato, dois dos grandes nomes da crítica literária, France e Brunetière, o primeiro escrevendo na prestigiosa coluna de Le Temps, La Vie littéraire, desde $1887^{41}$ e o segundo na tradicional Revue des Deux Mondes. Esse evento é fundamental para se entender as mudanças no percurso literário anatoliano. A própria concepção do que seria a crítica literária opunha Brunetière a France, o primeiro adepto a um sistema nos modelos do século XVII, inspirado na poética de Boileau, o segundo um contador de estórias, muito mais ligado ao século XVIII, e acusado pelo inimigo de

${ }^{40} \mathrm{O}$ romance é publicado em três partes, entre $1^{\circ}$ de julho e $1^{\circ}$ de agosto de 1889.

${ }^{41}$ France começa a escrever nessa época a coluna La Vie littéraire no jornal Le Temps. A sua rubrica inicial no jornal intitula-se La vie à Paris, mas em janeiro de 1887, France sucede Édouard Scherer na já conhecida coluna La Vie littéraire. 
fazer uma crítica impressionista. Esse debate marca uma ruptura na vida literária de France, pois foi nesse momento, em fins do século XIX, que o criador de Sylvestre Bonnard, orientou seu pensamento não na direção reacionária de seus pares, mas numa mais progressista. Nesse período, France reviu julgamentos feitos anteriormente, como em relação aos simbolistas Verlaine e Mallarmé, e principalmente a Émile Zola, elogiando-o em 1891 por ocasião da publicação do romance L'Argent.

Enquanto os debates modificam a posição de France diante do mundo literário francês, no Brasil, a sua leitura permaneceria a mesma: o sensualista da ironia e piedade. Seria necessário esperar o sensível olhar limabarretiano para vislumbrar a faceta engajada do escritor. É importante ressaltar, porém, que a defesa da liberdade de pensamento e reflexão não é um elemento novo na trajetória anatoliana. Ainda nos primeiros anos de vida literária, France se posicionara contra os antigos colegas parnasianos, como Leconte de Lisle, “de la famille des intelligences déspotiques", e contra os decadentes e simbolistas que, liderados por Mallarmé, instauravam, segundo ele, um "nouveau mysticisme". O gosto pela polêmica e pelo debate apareceram muito cedo na trajetória anatoliana e era a liberdade de pensamento e de reflexão, tão defendida pelo autor francês, que dava a ele a capacidade crítica, e, mais importante, a capacidade de revisão de suas próprias opiniões.

A postura crítica de France rendeu-lhe outro desafeto literário entre os seus pares: Maurice Barrès. Thibaudet traçou assim a filiação literária do nacionalista Barrès: “... le type d'existence littéraire qui commence avec Rousseau, prend tout son éclat avec Chateaubriand, explique la partie jouée par Lamartine et Victor Hugo, et où en somme Barrès." (Thibaudet, 2007, p. 498). Um dos personagens clássicos de Anatole France, o bem-humorado abade Coignard, é descrito pelo narrador de Les Opinions como o oposto de Rousseau: “Jean-Jacques aurait peu goûté la sagesse désabusée de notre philosophe. Rien ne ressemble moins à la philosophie de Rousseau que celle de M. l'abbé Coignard. Cette dernière est empreinte d'une bienveillante ironie." (OJC, 1987, p. 216). Ainda que não possamos ligar diretamente personagem e autor, a "bienveillante ironie" pode ser atribuída a criador e criatura. Do fundamento rousseauniano ao radicalismo nacionalista de Barrès, é fato que a oposição entre os dois escritores durará longos anos. Em 1908, na ocasião da transferência das cinzas de Zola para o Panthéon, Barrès, então deputado, evoca uma crítica do próprio France a Zola para denunciar o imoralismo do criador de Nana e se opor assim à homenagem ao naturalista francês. 
France, que já defendera Zola durante o caso Dreyfus, e mesmo antes já publicara artigos elogiosos sobre alguns de seus romances, se opõe a Barrès e defende a memória do escritor naturalista.

Na obra de Barrès, em função das oposições ideológicas, é possível apontar com clareza as diferenças (e semelhanças) entre os dois escritores. Em 1897, Barrès publica Les déracinés, primeiro volume da trilogia Le Roman de l'energie nationale, série escrita entre 1897 e 1902. Nesse romance, o narrador, por meio do professor Paul Bouteiller e de sete de seus alunos do liceu de Nancy, explora a passagem dos estudantes para a vida adulta desde a sua saída da região da Lorena, no nordeste da França, até os primeiros passos na capital Paris. Esses jovens que “... aspirent à se délivrer de leur vraie nature, à se déraciner.” (Barrès, 1967, p. 46) são acompanhados de perto pelo narrador que intervém constantemente expondo a sua opinião acerca dos personagens, de suas escolhas e decisões.

Barrès, por meio de seu narrador, cria uma espécie de romance de formação nacionalista. O professor e mestre destes bacharéis, o sr. Bouteiller, é um personagem sem apego à família ou a qualquer valor pessoal, que é bem sucedido pois considera o espaço público, o Estado francês, como o seu verdadeiro lar. O narrador intervém diretamente por meio do uso da primeira pessoa na narrativa - apesar de ser um romance narrado em terceira pessoa - criando interpretações do mundo por meio da trajetória de seus personagens, postos em ação com o fim de expor um argumento autoral. O termo prolétariat de bacheliers, por exemplo, cunhado pelo narrador, serve como síntese para a interpretação da situação dos bacharéis na França da época. Segundo o narrador-sociólogo, há nesse momento na França uma disparidade entre o número de bacharéis em letras e ciências e o número de vagas nas escolas para absorver essa demanda crescente de trabalho. E, para os alunos bolsistas, de renda mais baixa, como é o caso de Racadot e Mouchefrin, essa situação se coloca de forma ainda mais problemática.

$\mathrm{O}$ enfrentamento do mundo recebe do narrador um ingrediente a mais, o universo social é dividido entre ricos e pobres antes mesmo dos primeiros percalços no caminho dos jovens lorrains. Ao narrador-sociólogo, agrega-se um narradorinterpretador fortemente influenciado por um tipo de darwinismo social. O seu local de enunciação parte de um mundo já cindido: os destinos dos estudantes da Lorena estão marcados pela origem social e cultural. A decadência moral e física de Mouchefrin e 
Racadot, reduzidos a animais, não deixa dúvidas em relação à marca que o narrador reserva aos dois bolsistas. São somente esses dois que frequentam as brasseries, nas quais as mulheres da vida, como os dois jovens, dividem “... une animalité pareille, le goût de la boisson, des grosses nourritures, les privations de toutes sortes, le froid, la faim, un langage analogue" (Barrès, 1967, p. 152).

Aos mais ricos: o continuador de Taine, Roemerspacher, o aristocrata SaintPhilin, o advogado Suret-Lefort e o boulangiste belicoso Sturel, o destino se revela menos implacável. Até mesmo o jornalista pouco escrupuloso Renaudin escapa à animalidade reservada aos mais pobres, ainda que o narrador não deixe de criticá-lo. Também o antigermanismo se faz presente no romance na figura do ambicioso Portalis, chefe de Renaudin, cuja amoralidade é associada a sua origem germânica, outra oposição ao tipo nacional francês. O único antigo bolsista que tem sucesso na vida parisiense é exatamente Bouteiller, que seguiu o caminho do serviço à pátria, tornandose deputado ao final da obra.

Os destinos predeterminados desses desenraizados não poderiam encontrar eco em Anatole France. Nem mesmo os jovens discípulos de Bouteiller, que com a inspiradora visita ao túmulo de Napoleão I no Hôtel des Invalides, decidem criar um jornal, La Vraie République, em nada se assemelham aos discípulos anatolianos, como Jean Servien e Jacques Tournebroche. A obstinação de Racadot pelo jornal que financia com a herança materna, que sufocado em dívidas, e juntamente com Mouchefrin, mata Astiné Aravian, antiga amante asiática de Sturel, não poderia estar mais distante dos modelos anatolianos. $\mathrm{O}$ romance de tese de Barrès tem como sentido mais amplo compor um quadro geracional dos desenraizados, no qual os personagens servem como ilustrações de um princípio geral, o nacionalismo literário.

Do ponto de vista geracional, esses desenraizados estão também representados no romance de Bourget. Greslou, no capítulo "confession d'un jeune homme d'aujourd'hui', analisa as suas tendências hereditárias e diagnostica uma passagem das famílias de tradição antiga para as famílias modernas, sendo que nestas últimas não existiria "un trait commun dans la structure mentale et morale." (Bourget, 2010, p. 136). Esse descompasso que o personagem observa entre ele e sua mãe não é um caso isolado nos romances de fim de século. Ainda que não seja possível observar esse mesmo padrão nos desenraizados de Barrès, em função da diluição das individualidades em uma síntese geracional, a incompreensão entre filho e pais aparece sub-repticiamente na 
relação entre Racadot e seu pai, no que diz respeito ao uso da herança materna. O jovem quer investir no jornal, obter sucesso e permanecer em Paris, enquanto o pai deseja seu retorno ao interior onde ele poderia exercer uma função mais simples e adequada à sua origem.

Ainda que a pulverização dos personagens e a dissolução do enredo numa interpretação anterior do mundo em Barrès reduzam a individualidade dos atores, $o$ retrato da geração por ele traçado repercute não somente em Bourget, como também em France, particularmente em Jean Servien ${ }^{42}$. A diferença, porém, reside num elemento chave que não aparece claramente em Barrès, estando mais presente em Bourget: o embate entre o eu e o mundo desse herói romanesco ou talvez, seja possível se pensar num outro tipo de herói, um herói intelectual. No caso dos sábios e pupilos anatolianos, o narrador criar um espaço de conflito, no qual não há uma predominância ideológica, mas um oscilar entre as amarguras da vida e a beleza do mundo. Em comum com os seus pares, porém, está um flagrante de uma geração que, iniciada na vida intelectual, se descola do universo familiar e entra no espaço de debate público - e nele está o literário - um lugar até então reservado a outros grupos sociais.

Esse aspecto de mobilidade social nos meios literários merece uma nota no que tange aos dois países aqui estudados. A implementação do ensino primário laico e gratuito ocorreu de forma bem diferenciada no Brasil e na França. No Brasil, é preciso remontar ao Ato Adicional de 1834, que delegou às províncias a responsabilidade sobre o ensino primário. A lei de outubro de 1834 descentralizou a organização da instrução pública elementar no Brasil e essa direção foi mantida na Primeira República. No caso francês, os republicanos - convencidos da importância do ensino primário para a República desde 1848 - iniciam o projeto educacional pelas escolas primárias no nível federal. Jules Ferry, ministre de l'Instruction Publique de 1879 a 1883, institui as escolas primárias, gratuitas e laicas, excluindo a Igreja do Conselho Superior da Instrução Pública. Semelhantes do ponto de vista do ideário - já que na nossa Primeira República, a Reforma do ministro da Instrução Pública, Benjamin Constant, estava calcada, como na França, nos princípios da liberdade e laicidade do ensino, além da gratuidade da escola primária -, a forma de implementação foi bastante diferenciada. Em função da descentralização do ensino, o foco federal acabou recaindo no Brasil

${ }^{42}$ Não é de se estranhar, nesse sentido, a apreciação positiva que Barrès faz desse romance de France, como citamos anteriormente. 
sobre o ensino superior. Machado Neto (1973) estudou a profissão literária na vida intelectual brasileira de 1870 a 1930 e diante dessa premência do ensino superior no universo de bachareis, percebeu uma presença marcante do autodidatismo nas letras e na ciência.

No caso particular de Lima Barreto, Barbosa (1959; 2012) conta que o escritor frequentou a escola pública de D. Teresa Pimentel do Amaral, enquanto os estudos no Liceu Popular Niteroiense foram custeados pelo compadre de seu pai, o Visconde de Ouro Preto. Como France, Barreto estudou num dos melhores liceus de seu tempo, frequentado por gente rica. Entre os dois, portanto, as diferenças quanto à estruturação do ensino em cada país, não foram tão acentuadas como poderiam ser se Barreto não vivesse na capital. Na França, Anatole fez o ensino primário na "Institution SainteMarie, dirigée par l'abbé Meyer" (Bancquart, 1984a, p. 31), e os estudos secundários foram custeados pelos seus pais no Liceu Stanislas, escola de perfil aristocrático. Ambos, apesar da má experiência narrada pelos seus biógrafos nos estudos secundários, tiveram uma ascensão educacional que não fora possível aos seus pais.

Esse período de mudança educacional nos dois contextos nos dá alguns elementos para refletir acerca das semelhanças e diferenças das situações sociais dos dois autores estudados, agregando informações relevantes para a relação aqui proposta, principalmente se pensarmos a literatura comparada também como um estudo no qual o literário, o histórico, o social e o biográfico são essenciais para fornecer maior profundidade às reflexões. A geração de romancistas da qual France faz parte é testemunha, segundo Thibaudet, de uma transformação cuja origem está nas questões intelectuais que modificam a forma do romance:

“... transformant la défaillance du roman en un roman de la défaillance, utilisant ce reflux comme force motrice, s'exprimant sous les formes plus intellectuelles que vitales du roman personnel, du roman d'analyse, du roman-thèse et du roman-mythe qu'ont renouvelés les écrivains et romanciers considérables de ce temps, Loti, Bourget, France, Barrès, Gide." (Thibaudet, 2007, p. 450).

A fragilidade se converte aqui em força criadora, porém, o que enseja essa transformação, não são as questões formais, mas as questões intelectuais, os debates da época. A precisa definição do crítico une Barrès, France e Bourget, ainda que entre eles sejam muitas as diferenças ideológicas, políticas, e mesmo estéticas. Em se tratando de romances de heróis intelectuais, a geração se assemelha, ainda que as posições autorais 
revelem caminhos distintos, tomados por cada escritor no decurso das respectivas trajetórias. E não se pode dizer que as posições do autor no mundo não influenciem a sua obra. A breve comparação entre o imobilismo ideológico de Barrès e a libertade de pensamento de France nos fornece elementos suficientes para pensar mais a fundo na forma como essas diferenças ideológicas foram transpostas para o estético. Essa semelhança geracional $^{43}$ e essa diferença ideológica se repetem na relação de France com Paul Bourget.

Thibaudet define Bourget opondo-o a Zola: romance psicológico versus romance fisiológico, público erudito versus público pequeno-burguês, romance de direita versus romance de esquerda. Quanto à forma do romance, o crítico francês ressalta o talento oratório de Bourget, mas também afirma que a imobilidade de suas ideias tornou sua obra datada e ligada ao passado. Apesar das semelhanças com France, "dans les deux cas, la création est subordonée à des idées" (Thibaudet, 2007, p. 457), o criador do carismático Coignard soube não somente escapar ao imobilismo parnasiano como oporse aos seus pares em defesa do capitão Dreyfus. A independência e a flexibilidade são o sopro de vitalidade de sua obra, o seu “'avant-gardisme' à l'époque où presque toutes les valeurs françaises étaient nationales, et nationalistes” (p. 461). Le Disciple, é, segundo Thibaudet, "le premier roman de l'éducation intellectuelle", no qual a renovação de ideias se coloca de maneira exemplar.

Nesse momento, renovam-se ideias e literatura. Os mestres de Bourget e France, Ernest Renan e Hyppolite Taine, morrem respectivamente em 1892 e 1893, e os debates entre a ciência e a moral surgem como sintoma dessa urgência de renovação. A querela em volta do livro de Bourget é parte desse contexto e, de certa maneira, antecipa outros acontecimentos relevantes na França do final do século XIX. Segundo Antoine Compagnon, no prefácio da edição da obra de Bourget: "la querelle du Disciple préfigure les positions des uns et des autres pour longtemps: dans la guerre de deux Frances; elle sert de répétition généreale à l'affaire Dreyfus, à la séparation des Églises et de l'État, et au-delà." (Bourget, 2010, p. 36).

O sentimento nacionalista aparece com outra roupagem no Brasil. Segundo Prado, o nacionalismo brasileiro na época aparecia travestido de "metáfora de uma ilusão hegemônica em que povo e nação se transformam num conjunto articulado e

\footnotetext{
${ }^{43}$ Thibaudet lembra que tanto France como Bourget viveram entre o Império e a República.
} 
harmônico"44 (Prado, 2004, p. 13). A ilusão seria decorrente não somente do descompasso visível entre uma elite nababesca e um povo miserável, mas também no agravamento dos conflitos sociais na recém-formada República, com o sufocamento de revoltas populares como a de Canudos, no sertão baiano, e a Revolta da Vacina, no Rio de Janeiro. Do ponto de vista do nacionalismo, é importante lembrar também da Guerra do Paraguai, encerrada, como a guerra entre França e Prússia, no ano de 1870. Essa ilusão de harmonia encobre o mapa ideológico brasileiro, dificultando uma contraposição mais clara entre os grupos de escritores e intelectuais, como vimos mais explicitamente no caso francês. O que não deixa dúvidas, porém, é a posição antagônica de Lima Barreto em relação aos literatos, aos nacionalistas, aos positivistas; em suma, a tudo que representasse uma restrição ao exercício crítico e autônomo de sua literatura militante.

Reside nessa chave crítica, a leitura bastante peculiar do escritor brasileiro que soube ver no sensualista France além do que viram seus pares, e soube interpretar não somente o romancista como o crítico social e político. Mais do que isso, a posição crítica enseja nos dois escritores um local de enunciação limiar: no oscilar entre as mazelas do homem e a beleza do mundo, entre o subjetivo e o social; entre a poeticidade do espaço e o satírico; afastados dos realismos, mas não da realidade. Esse oscilar na escrita revela algo sugerido por Thibaudet que vimos aqui no breve retrato de uma geração que atravessa, em maior ou menor grau, um momento de dúvida, de fragilidade. Como bem sugeriu Thibaudet, transformando "la défaillance du roman en un roman de la défaillance”, e utilizando essa fraqueza como força em romances de análise que flagram uma geração e uma transformação. Como previra France no prefácio de Les Opinions:

Vivre c'est se transformer, et la vie posthume de nos pensées écrites n'est pas affranchie de cette loi: eles ne continueront d'exister qu'à la condition de devenir de plus en plus différentes de ce qu'elles étaient en sortant de notre âme. Ce qu'on admirera de nous dans l'avenir nous deviendra tout à fait étranger. (OJC, 1987, p. 209)

\footnotetext{
${ }^{44}$ Nessa ideia de ilusão harmônica, Prado lembra o conde Afonso Celso, no libelo de 1900, "Por que me ufano de meu país".
} 


\section{Herói Intelectual}

Sugerimos anteriormente que o processo de educação intelectual de alguns personagens de France e de Barreto se traduziria numa nova crise do herói romanesco, uma crise deflagrada pela mundança de status cultural e social de uma geração de escritores. Essa sugestão parte da observação, nas leituras de Lima Barreto, Anatole France e contemporâneos daqui e do além-mar, de um tipo particular de herói romanesco. Em muitas análises dessas obras, há uma direta associação entre personagem e romancista, uma simbiose que se estabelece em função do caráter dissertativo, e eventualmente moralizador, de boa parte delas. Romances psicológicos, de tese, de ideias, são todos tipos de obras nas quais se cruzam vida do autor e vida do personagem.

Essa é a chave de interpretação constantemente seguida por Marie-Claire Bancquart na análise das obras de Anatole France, a associação entre o percurso do personagem e o de seu criador. De fato, a associação entre criador e criatura é inevitável, porém, não gostaríamos de seguir aqui somente nessa chave de elucidação correlativa, mas de sugerir a existência, nesse emaranhado de relações, de algumas características dessas obras que configuram não uma associação individualizada, mas compartilhada por um grupo de escritores que busca no gênero romance a sua forma de expressão artística e social. No ensejo dessas características, trataremos neste capítulo das características dos personagens, ou mais precisamente, de um tipo de herói com grande presença nos contextos sobre os quais nos debruçamos: o herói intelectual.

O termo herói intelectual é o título do livro de Victor Brombert (1961). Ele traçou uma linha "genealógica" e temporal que vai de Jules Vallès a Simone de Beauvoir, de 1880 a 1955. Segundo Brombert, o século XX francês foi invadido por intelectuais e, nunca antes na ficção, a experiência foi tão frequentemente filtrada pelas mentes dos protagonistas. Para Brombert, esse herói intelectual está diretamente ligado à crise do humanismo e da ciência, uma geração herdeira do legado de Hippolyte Taine e Ernest Renan e de uma revolução no processo educacional. Para compreendermos melhor essa figura, retomaremos alguns pontos da concepção desse herói, segundo Brombert, para num segundo momento, discutir as características essenciais desse tipo e a sua presença em Anatole France e Lima Barreto. 
O surgimento do termo intelectual ${ }^{45}$ é complexo e deixou marcas históricas. No estudo sobre o herói intelectual, Brombert trata de alguns estigmas atribuídos à figura do intelectual, principalmente por parte da crítica nacionalista e tradicional francesa, que permaneceram latentes durante longo tempo. Eles são, dentre outras coisas, acusados de falarem de assuntos dos quais não têm conhecimento, caracterizados como aristocratas do pensamento e denunciados como inimigos da nação. Um dos estigmas mais complexos é a posição ambígua que partilham no meio social: “... the intellectuals find themselves in the ambiguous position of being classified simultaneously as an aristocracy and as a prolétariat." (Brombert, 1961, p. 29). De fato, a figura do intelectual foi alvo, durante os acontecimentos do caso Dreyfus, de represálias tanto da extrema direita como da extrema esquerda. Enquanto a direita questionava a validade dos métodos científicos e a nova classe de "bacheliers" que chegava ao poder, a esquerda via no caso uma questão estritamente burguesa, que nada tinha a ver com a luta do proletariado.

Dentre os ancestrais da figura literária do herói intelectual que aparece concomitantemente ao personagem histórico, Brombert cita as obras de Jules Vallès, Paul Bourget, Émile Zola, Anatole France e Roger Martin du Gard. Dentre esses nomes, nos parece equivocada somente a atribuição da ancestralidade a Bourget, cujo herói estaria mais para um anti-intelectual, assim como os personagens de Barrès. Tanto o professor Sixte como Bouteilleur, seja no estilo caricatural do primeiro, ou na bizarrice do último, são figuras símbolo da crítica nacionalista e de direita ao intelectual. Quanto a Barrès, parece-nos que Brombert pensa da mesma maneira, pois caracteriza Bouteiller como um tipo de feiticeiro que dissemina o seu "veneno intelectual" e desenraiza toda uma geração de jovens franceses. Também o professor Sixte, segundo o próprio Brombert, é um personagem criado por Bourget, para demonstrar o efeito pernicioso para a nação do pensamento científico nos jovens. Ainda assim, ele dedica todo um

${ }^{45}$ Segundo Winock (1998), na sua forma substantiva, esse nome teve sua primeira definição pública em janeiro de 1898, quando Georges Clemenceau, jornalista e político francês, escreveu um artigo felicitando eruditos, artistas e universitários que assinaram a petição a favor da revisão do processo Dreyfus. A professora de história Madeleine Rebérioux, porém, afirma que o termo intelectual já havia aparecido com a mesma função em um romance de Barbey d'Aurevilly, Les Chevalier de Touches, de 1864, depois em Maupassant, em 1879 e enfim em Leon Bloy, em 1886. Rebérioux concorda, porém, que o seu emprego dentro do debate público que se formou durante o caso Dreyfus agrega elementos novos ao uso da palavra intelectual, uma vez que não somente marca a entrada desses intelectuais na vida política, como as palavras proferidas por esses intelectuais se apresentam sob um novo valor, embebidas no reconhecimento anterior de suas respectivas carreiras artísticas e intelectuais. 
capítulo ao estudo dessa obra de Bourget. Mas ao final do capítulo, o próprio Brombert lembra que o autor de Le Disciple condenou o "roman à thèse" como um gênero falso defendendo, em oposição, sua literatura de ideias como legítima. A única forma de inserir os personagens de Bourget e Barrès nessa lista seria a partir de uma concepção mais larga desse novo herói; não a partir da figura histórica do intelectual engajado, mas de uma imagem geracional em relação a uma figura que se debate com as heranças pregressas.

No caso de France, Vallès, Zola e du Gard é possível visualizar com mais clareza a relação entre a figura do intelectual e o herói romanesco. No caso de Anatole France, particularmente, é possível dizer que a trajetória dos personagens e a trajetória intelectual do autor são concomitantes e se encaminham para um pensamento de esquerda. Por isso, talvez, a sensação de similitude entre autor e narrador ou herói, sempre explorada no caso de France. O mesmo se dá com a trajetória intelectual de Émile Zola, escritor cuja ascensão social, intelectual e literária guarda afinidades com o percurso de Anatole France. Além de terem sido ambos dreyfusards, Zola e France compartilharam a experiência de um fenômeno geracional de "democratization of literature", no encalço da democratização do ensino. O prolétariat de bacheliers de Barrès é uma interpretação depreciativa dessa geração, na qual o intelectual representaria uma ameaça à ideia de nação francesa.

Se Zola e France se aproximam deste ponto de vista autoral, o mesmo não se pode dizer em relação à figura ficcional do herói intelectual. Eles apresentam soluções distintas nos romances, como bem apontou Brombert ao atribuir ao herói zoliano a figura do apóstolo e ao de France, a do sensualista intelectual. A visão unificada e salvacionista de Zola, principalmente nas suas duas últimas séries ${ }^{46}$, escritas depois do caso Dreyfus, opõe-se ao ambíguo herói intelectual anatoliano, na sua particular junção do mundo das sensações e da inteligência. E é exatamente no paradoxismo dessa relação entre o eu e o mundo que a figura do intelectual anatoliano do fim de século se forma e guia toda uma geração de escritores no começo do século XX. A premissa da liberdade do indivíduo autônomo é anterior em France e seus personagens vivenciam o conflito ao mesmo tempo que refletem sobre a experiência, em meio ao turbilhão dos acontecimentos. A ambiguidade, tão criticada na configuração do herói intelectual, é

\footnotetext{
${ }^{46}$ Les Trois Villes e Les Quatre Évangiles.
} 
fundante na obra anatoliana: seu herói é marcado por ela, assim como o herói limabarretiano.

\section{O percurso de Servien e o descolamento de Caminha}

Les Désirs de Jean Servien é, segundo Bancquart, um romance "qui soulève le plus grand nombre d'énigmes", bem diferente do seu antecessor Le Crime de Sylvestre Bonnard, assim como de grande parte da obra de France, marcada pela galeria de sábios e por um tom leve e irônico. A história de Jean Servien é, de fato, particular no conjunto da obra de France. Bancquart busca associar a escrita do romance a uma fase anterior do autor, quando ele "a cessé de croire en la positivité indiscutable de la science" $\left(\right.$ Bancquart, 1984, p. 1185) ${ }^{47}$. A referência autobiográfica é o que interessa à crítica. Do nosso ponto de vista, por outro lado, é a peculiaridade desse romance que o faz relevante no encalço desse novo herói em crise.

O percurso de Jean Servien, que vive entre um universo familiar simples e trabalhador e um mundo de alta cultura, ao qual tem cada vez mais acesso, corresponde ao dilema de uma geração que, agora instruída, participa de outros círculos sociais antes restritos ao de nascimento ${ }^{48}$. Servien é filho de um relieur, uma espécie de brochurista ou encadernador. Ele perde sua mãe em tenra idade e é criado pela tia, primeiramente no campo, depois, aos sete anos, vai viver em Paris. Na capital, ele aprende latim com o marquês italiano Tudesco, tipo jocoso como Coignard, e, com onze anos, seu pai, "bien qu'il gagnât peu", coloca Jean numa boa escola de ensino regular. Com o colega Ewans, Jean experiencia a vida da classe rica e começa a sentir o desgosto de sua origem familiar: "En rentrant au logis, il s'aperçut pour la première fois d'une odeur de colle qui lui sembla insupportable." (DJS, 1984, p. 357). Esse evento transforma o menino que agora sonha com este outro mundo: “... Jean se crut malheureux et il le devint en effet." (p. 359).

${ }^{47}$ A questão da ciência, particularmente nessa geração que cresceu sob a influência de Hippolyte Taine e Ernest Renan, está muito presente nas discussões da época, e a despeito de France ter sido fortemente influenciado por ambos, mas principalmente por Renan, sua posição é bem mais questionadora.

${ }^{48}$ Os republicanos deram uma atenção especial ao sistema educacional na França. Em 1881, a escola primária se torna gratuita e nos anos seguintes, a laicização do ensino atinge os programas, os locais e os professores. Os liceus são pagos na época, mas a ajuda das bolsas, como aparece nos déracinés de Barrès, torna possível o ingresso de estudantes provenientes de classes sociais mais baixas nos futuros quadros da nação. Essas informações estão em Démier (2000). A trilogia de Jules Vallès, L'Enfant, de 1879, Le Bachelier, de 1881 et L'Insurgé, de 1886, é outro exemplo dessa nova configuração possível na história de Jacques Vingtras. 
Aos dezoito anos, ele se apaixona obsessivamente por uma atriz: "Il s'abandonnait [...] au courant d'une passion brillante et qu'il croyait profonde." (DJS, 1984, p. 364). A partir de então, o seu estado de melancolia se agrava e ele passa os dias envolto com os livros, os passeios pela cidade e as idas ao teatro. Seu pai, preocupado com o enfastiamento de Jean, pede-lhe que se esforce para realizar o exame de ingresso no ministério das Finanças, com o auxílio do Sr. Bargemont, que, como Barrès, também enfatiza o despreparo dessa nova classe de bacheliers: "Pour Dieu! Ne nous donnez plus de bacheliers. Nous ne savons qu'en faire ...” (p. 366). A contradição da vida de Jean vai se tornando cada vez mais dramática. O seu pai, seguindo o desejo da mãe de Jean de fazer do menino um homem instruído, trabalhava exaustivamente para realizar a vontade materna. Porém, esse esforço não estava sendo recompensado e, pelo contrário, só lhe trazia decepção: “J'ai travaillé comme une bête de somme [...] Ah! Si je savais que ton instruction t'eût fait prendre le goût de la paresse, je regretterais de n'avoir pas fait de toi un ouvrier comme moi." (p. 368-369).

Por algum tempo, tocado pelo discurso do pai, Jean se dedica aos estudos para ingressar no ministério das Finanças. Porém, um novo encontro com o bon vivant Tudesco, o traz de volta aos prazeres dos livros, ao amor pela atriz e à lassidão. Esse movimento entre a vida trabalhadora e a vida dos prazeres sensuais é reforçado pelo narrador no encontro de Jean com um antigo colega do pensionato, Garneret, “... cette nature de bon ouvrier, pour laquelle le monde est une immense usine." (p. 388). Jean não passa no exame mas acaba tornando-se um pion, uma espécie de bedel de instituição de ensino. Neste ofício, nos intervalos do trabalho, Jean poderia se preparar para obter o título de "licencié ès lettres", o que lhe daria acesso ao ensino superior. Mas, a tranquilidade de alguns meses de estudo e trabalho é novamente rompida pela visita de Tudesco, e Jean abandona os estudos para se engajar na guerra contra a Alemanha, guerra perdida pela França em 1870.

O encontro com Tudesco, agora engenheiro e coronel da Comuna, altera mais uma vez o destino de Jean. Durante conversa com o ex-mestre, o rapaz acaba afirmando que Bargemont, então amante de Gabrielle - a atriz alvo da paixão de Jean - seria um bonapartista e inimigo do povo de Paris. Tudesco tenta então prendê-lo, mas como não consegue, envia um retrato de Gabrielle a Jean, que vai ao seu encontro, entender o que tinha se passado. Ele então surpreende Tudesco, bêbado, saindo da sala de Bargemont, e gritando "Au secours! Au secours! On me tue" (p. 425). Os seguranças entendem que 
Jean seria o responsável pela ameaça, e ele é então preso e fuzilado. O fim do herói é descrito melancolicamente pelo narrador:

"Le corps de Jean Servien resta étendu sur la voie déserte [...] il y avait à la tempe un petit trou à peine visible; du sang et de la boue souillaient ces beaux cheveux qu'une mère avait baisés avec tant d'amour." (DSJ, 1984, p. 427).

Assim como Servien, Isaías Caminha também é um menino de origem pobre que se descola de sua ascendência e ruma em direção à capital com o desejo de ser "doutor". Os "anseios de inteligência" de Isaías fazem com que o menino se dedique "açodadamente" aos estudos, esquecendo-se de qualquer atividade infantil. Esses primeiros estudos o fizeram sentir-se diferente dos seus pares: "Veio-me a pose, a necessidade de ser diferente." (IC, 2010, p. 68). É o começo do seu deslocamento na direção oposta à sua origem familiar. Nesse processo de distanciamento, a notícia do sucesso de um antigo colega de escola, “O Felício! Tão burro!”, é um dos fatores que decide Isaías no seu intuito de seguir para a capital. Daí para frente, é o título de doutor que o jovem tem em mente, o que "resgataria o pecado original do meu nascimento humilde, amaciaria o suplício premente, cruciante e onímodo de minha cor ...” (IC, 2010, p. 75) ${ }^{49}$.

Isaías, no momento de maior dificuldade financeira, quando "nada mais tinha que vender", passando dias inteiros sem alimento, recebe uma carta dizendo que sua mãe estava muito doente, à beira da morte. Nesse momento, ao mesmo tempo em que ressente profundamente aquela vida "humilde e humilhada" da mãe, as lembranças de Isaías não o levam de volta à casa da mãe e à origem simples. Mais do que isso, as lembranças dos dias de infância, do abraço da mãe depois do colégio, dos cuidados na doença, tudo se embaralha na mente de Isaías: "E tudo vinha com pressa do fundo de mim mesmo, subia uma recordação que expulsava outra; por fim, tudo se baralhou, tornou-se confuso e os meus olhos se orvalharam de pranto". (p. 168). Isaías tinha, definitivamente, rompido com a sua ascendência. As trajetórias de Servien e Isaías também guardam paralelos nas conclusões dos romances: enquanto o primeiro tem uma morte trágica, Isaías é assimilado pela "fábrica de carapetões", de mentiras -

${ }^{49}$ É importante observar aqui uma distinção: o distanciamento de Servien é de sua família pobre e humilde diante do anseio de um jovem estudante inebriado com o mundo do conhecimento e da riqueza. No caso de Isaías, é preciso frisar uma tentativa de descolamento de uma estrutura mais profundamente arraigada, a superação não somente da ascendência humilde, como da origem racial. A despeito de eventuais diferenças, o distanciamento da origem familiar está presente nos dois romances. 
denominação do narrador para o jornal - e se torna deputado. Em ambos, os anseios de infância nunca chegam a se concretizar.

\section{Criador e criatura}

Ainda que não seja nosso objetivo fazer uma ponte direta entre o personagem e o seu criador, não é possível deixar de lado a trajetória pessoal de Lima Barreto e Anatole France diante desses personagens com fortes traços autobiográficos. Filho de tipógrafo e, depois, escriturário das Colônias de Alienados da Ilha do Governador, Lima Barreto perdeu a mãe muito jovem. Assim como o jovem Isaías, era um aluno aplicado que não gostava de brincar, como conta Francisco de Assis Barbosa. Também como Isaías, Barreto frequentou ótimas escolas, como o Liceu Popular Niteroiense. Além disso, criador e criatura amavam os livros e o mundo do conhecimento.

Como Servien, Anatole France vem de uma origem humilde. Sua avó materna, Amable-Antoinette era filha de um mineiro e sua mãe foi uma "enfant naturelle", criança declarada de pai desconhecido, situação muito mal vista pela sociedade francesa da época. Já o pai de France, François-Noël Thibault, é o último dos cinco filhos de um sapateiro com a filha de um humilde comerciante, que concluiu seus estudos no exército, onde aprendeu o ofício de "chasse aux documents", permanecendo nessa atividade até se tornar livreiro, função que exerceu até o fim da vida. Como bem descreve Marie-Claire Bancquart: "Anatole est le fils d'un ancien illettré, pour qui les livres sont une conquête" (Bancquart, 1984a, p . 40). Apesar de ter vivido a consagração em vida, France esteve, durante muito tempo, numa posição delicada. Os irmãos Goncourt, frequentadores da livraria do pai de France, notam e publicam em seu jornal a problemática do estudante humilde num liceu regido por uma sociedade de administração fortemente aristocrática, le Stanislas:

Nous entrons chez France le libraire honnête et légitimiste. Son fils est à Stanislas. Au lieu d'avoir, comme son pére, un état indépendant et lucratif, lui donnant ses aises et de l'argent assez pour éduquer ses enfants, il sera, ses études faites, lui, fils d'un bouquiniste, três fièrement bureaucrate à $1800 \mathrm{~F}$. (Bancquart, 1984a, p. 34).

Está implícito no diágnostico dos irmãos Goncourt, o preconceito que sofre o autor, semelhante ao personagem Servien. A situação de Isaías é semelhante. O que ressaltamos no caso dos romances de Servien e Isaías, que remete aos autores Anatole France e Lima Barreto, é a marca do lugar de origem e a relação quase carnal com os livros, advinda de uma paixão paterna. Alguns traços biográficos se repetem na ficção, 
elementos em perfeita sintonia com o tipo do herói intelectual. No caso dos romances e da vida, o que está em jogo é um processo de desenraizamento, uma situação hors et là, como bem definiu Bancquart acerca da trajetória anatoliana. Para a estudiosa, France é "là" no mundo da cultura clássica, na sociedade de sua época, mas é "hors", vindo de uma família pobre, "promu par hasard aux études" (Bancquart, 1994a, p. 21), sabendo que nunca estaria totalmente adequado a nenhum dos dois ambientes.

No caso de Barreto, os estudos no Liceu foram custeados pelo padrinho, o visconde de Ouro Preto. Até os tempos de colégio, Barreto não sentia, segundo conta Barbosa, a diferença de classe em relação aos colegas, mas depois do ingresso na escola Politécnica, ele passou a sofrer com a convivência com os mais ricos e a perceber que a sua origem humilde o tornava diferente dos outros rapazes da sua idade. Não é essa uma sensação semelhante à de Isaías quando pensa na ida para a capital e teme ser "como uma palha no redemoinho da vida - levado daqui, tocado para ali, afinal engolido no sorvedouro... ladrão... bêbado... tísico e quem sabe mais?” (IC, 2010, p. 69)? Não é o mesmo sentimento de Servien que se sente desprezado pela mãe do colega Ewans, por não saber dançar? Ou do jovem enamorado e rejeitado pela atriz amada que reconhece nele "un menu bourgeois, vivant tranquillement de peu, nourri dans l'épargne serré ..."? (DJS, 1984, p. 384).

Criadores e criaturas também guardam no íntimo desejos de grandeza. France, ainda jovem, descreve o seu projeto de ascensão rumo à consagração literária, num “cahier d'honneur de l'académie de Stanislas", de junho de 1859: “... vous retournez la dernière feuille, et vous voyez un plan tracé par le potache, qui va de sa maison natale, quai Malaquais, à l'Académie, la vraie, celle du quai de Conti." (Bancquart, 1994a, p. 21). Barreto também, em suas três tentativas de ingressar na Academia Brasileira de Letras, revela, a despeito do crítico contumaz da sociedade que sempre foi, o desejo de consagração. Não são os mesmos arroubos de Isaías Caminha e o seu sonho com o título de doutor? Não são os mesmos desejos de pertencer ao mundo dos ricos do pequeno Servien admirando a mãe do amigo rico ou do jovem buscando a amante habituada com o mundo da alta burguesia?

Do ponto de vista biográfico, France alcançou seus objetivos de menino, o que não aconteceu com Barreto. Os seus personagens, Servien e Isaías, porém, apesar de terem destinos distintos, fracassam ambos nas suas ambições iniciais. Servien acaba fuzilado, sem alcançar nem mesmo o amor da atriz amada, enquanto Isaías é tragado 
pelo mundo do jornal e da política e acaba aceitando um destino muito diferente daquele com o qual sonhara. Ambos foram frustrados nos seus desejos de grandeza, ainda que Isaías tenha sucumbido pela passividade e Servien pela morte. A despeito de pequenas diferenças, importa salientar a existência nesses dois romances de início de carreira de uma mudança na relação entre o indivíduo e o mundo no percurso do herói romanesco. No trajeto de formação desses jovens, o que nos chama a atenção é a transformação do que se convencionou chamar de romance de formação. Enquanto personagens como Julien Sorel e Frédéric Moreau experimentaram a existência, aventuram-se no mundo, Jean Servien e Isaías Caminha o fazem sob um olhar reflexivo, meditando sobre seus percursos no mundo. Eles tentam cruzar dois mundos, mas acabam retidos no meio, num espaço hors et là, refreados pelos excessos reflexivos.

Os personagens chegam a se tornar no percurso das obras de France e Barreto, como buscaremos apontar no estudo final das sátiras, um pretexto para o discurso, para a reflexão sobre o passado, o presente e o futuro. Mas, nesses primeiros romances, o que se pode observar é a transformação da experiência em reflexão, diante da qual o pensamento passa a substituir a ação. Nessa transformação, o herói romanesco se converte em herói intelectual, chegando em alguns momentos ao nível caricatural em função da natureza pessimista do seu humanismo e do excesso de erudição, segundo Brombert. Para ele, o herói intelectual que se transfigura em uma caricatura de si mesmo é uma das fraquezas desse novo herói romanesco. Fraqueza atribuída não somente à natureza do personagem, como ao tratamento dado pelo narrador ao herói, um tratamento muitas vezes superficial, sem visão integrada e repleto de alusões eruditas e efeitos estilísticos.

Assim como o personagem descrente, também o ficcionista parece não acreditar nas suas próprias criaturas e criações. France, segundo Brombert, prefere estabelecer um “direct dialogue with his reader" (Brombert, 1961, p. 92) por meio das digressões. O personagem se torna às vezes um pretexto, uma ilustração de digressões do autor, daí o efeito de caricaturização. Isso acontece em parte pois estamos lidando com humanistas inseridos num mundo no qual o humanismo se esvai lentamente. Também estamos lidando com uma realidade mais premente que a ficção como o próprio Anatole France declarou em uma entrevista concedida a um jornal italiano em $1903^{50}$. A situação do

\footnotetext{
${ }^{50}$ Em 24 de maio de 1903, no Giornale d'Italia, France afirma ao jornalista Domenico Oliva que "l'actualité éclipse à ses yeux l'intérêt de la littérature et de l'art contemporains" (Bancquart, 1991, p. XIX).
} 
mundo e a consequente descrença na capacidade de transformação de seus personagens inscreve esses romances num quadro de crise da representação do herói romanesco. $\mathrm{O}$ narrador, então, toma a palavra do personagem, transferindo para ela um papel central na obra.

Esses romances digressivos, nos quais criador e criatura se entrelaçam como representantes de uma geração, são resultado de um tempo no qual as expectativas de transformação (com a República, a política, o mundo literário) não foram cumpridas. A fraqueza ou a força desse tipo de romance reside na capacidade do narrador em criar um universo coerente com esse desapontamento, seja na construção de uma trama envolvente (o caso de Le Disciple), seja na criação de um personagem carismático (o caso de Jérôme Coignard), seja na internalização do conflito entre o eu e o mundo na própria estrutura do romance (caso de Isaías Caminha). O desafio dessa geração da inteligência é pensar a ficção a partir das ideias, sem que elas tomem o espaço da narrativa e com um personagem suficientemente forte para ligar os elementos ficcionais e fugir da caricaturização como efeito de um excesso digressivo ou erudito. Thibaudet percebeu essa subordinação da criação à ideia em France e Bourget: "Dans le deux cas, la création est subordonnée à des idées [...] Dans le deux cas, il s'agit d'un reflux du roman, accordé à une époque où sont goûtées les valeurs d'intelligence. (Thibaudet, 2007, p. 457) ${ }^{51}$.

O foco nas ideias, formalizado nas digressões dos personagens, é, ao mesmo tempo, o ponto forte e a fragilidade dessa geração de heróis intelectuais. Ponto forte, pois é refletindo sobre o mundo que o herói intelectual se torna capaz de organizar, ainda que temporariamente, um mundo em crise; fragilidade, pois essa estrutura marcou as obras de boa parte desses autores como datadas, ou consideradas como adequadas

\footnotetext{
${ }^{51}$ Como já tratamos brevemente no capítulo anterior, a obra de France foi muito mal vista depois de sua morte, em 1924. Na biografia de France (Anatole France, un sceptique passionné), Bancquart lembra que o crítico Thibaudet foi um dos poucos que percebeu essa geração nas suas particularidades e viu a crítica a France pelos surrealistas como um sinal do valor simbólico de sua figura. Num texto publicado em La Revue universelle, Thibaudet afirmou: “Anatole France est mort au moment où s'ouvrait la première de nos crises d'après-guerre, ce qu'on a appelé la crise du concept de littérature. La crise de sa mémoire est liée à la crise de ce concept, qui n'est pas terminée. Elle implique un cas plus vaste que son cas personnel. Mais cela reste un honneur pour lui, que son cas prenne une valeur de symbole, que ce faiseur de mythes devienne un mythe littéraire, qu'autour de cet héritier des littératures puisse se former le plus clair du problème de leur héritage." (Thibaudet apud Bancquart, 1984, p. 408). Bancquart não cita o ano de publicação na biografia, mas tudo indica que se trata do número 13 da revista, de 1934, na qual Thibaudet escreve "Anatole France 10 Ans Après". A posição do crítico diante dessa geração é o que faz de sua presença uma constante na situação da obra de Anatole France, já que grande parte dos críticos franceses parece ter deixado de lado esse momento da história literária depois da morte de seus maiores representantes.
} 
somente ao gosto de uma época específica. Enfim, esses heróis intelectuais se caracterizam, entre outras coisas, pela inação e falta de controle do seu destino, pela origem humilde e fragilidade, pela infância idealizadora, pela luta por um espaço de consagração, pela presença constante da figura quase religiosa da mãe e pela figura dos sábios com centralidade na narrativa. São o reflexo conjunto de crises políticas e literárias que se juntam nesse amálgama de criador e criatura.

No encalço das origens remotas desse tipo literário, Brombert traça uma genealogia que recupera como ancestrais do intelectual moderno os filósofos do século XVIII, tão mal vistos à sua época como os intelectuais no fim do século XIX. Brombert aponta ainda para a centralidade de Paris, como capital intelectual, na qual circulavam grupos das mais diversas filiações ideológicas, e ressalta o processo de ampliação desse grupo exatamente com a proliferação dos bacheliers, uma inteligência sem origem aristocrática, educada, mas até então sem acesso ao poder político e cultural desse mundo efervescente que foi a cidade de Paris na virada do século.

Esse tipo literário aparece na história literária francesa carregado de paradoxos, representando uma espécie de consciência que liga a experiência literária à vida política e social da efervescente Belle Époque parisiense. Esse debate fervoroso, como se viu no caso Dreyfus, de posições ideológicas em oposição, certamente, não se deu na mesma proporção no Brasil, apesar das discussões em torno da República e da abolição da escravidão. A limitação do debate público tem, certamente, raiz no reduzido número de grupos com um mesmo nível de escolaridade e participação na vida do país. Porém, é importante lembrar, no caso brasileiro, uma leva de romancistas muito pouco conhecidos que propuseram em suas obras a construção de um mundo embasado no salvacionismo de Léon Tolstói. Esse breve retrato nos permitirá melhor posicionar esse herói intelectual no Brasil.

\section{Romances tolstoístas}

A vertente tolstoísta ${ }^{52}$ no Brasil contou com alguns representantes, ainda que esses romances estejam hoje esquecidos. Prado (2004) examina três romances dessa linha: O ideólogo, de 1903, do médico e escritor anarquista Fábio Luz, Regeneração, de 1904, do jornalista e escritor Curvelo de Mendonça, e Redenção, de 1914, do escritor Veiga Miranda. A hipótese defendida por Prado é que, particularmente nos romances de

\footnotetext{
52 Agradeço ao professor Antonio Arnoni Prado pelo empréstimo de todas essas obras de difícil acesso. Exatamente por serem obras de pouco acesso, alongaremos um pouco as tramas destes romances.
} 
Luz e Mendonça, os esboços de herói tolstoiano na prosa brasileira aliam-se ao conservadorismo da burguesia ilustrada ou ao latifúndio, a partir da família como célula mestra de transformação. Diz Prado que, se o leitor atentar para as transformações das personagens principais verá, "espantado”, a adaptabilidade do espírito empreendedor do latifúndio "quando se trata de promover a revolução no campo sem abrir mão do controle da riqueza" (Prado, 2004, p. 82). Já no caso de Veiga Miranda, Prado enxerga uma relação mais próxima com a realidade fugindo, assim, à narrativa do utopismo dos dois outros romances. ${ }^{53}$

Francisco de Assis Barbosa lembrou o "surto de uma certa literatura social" (Barbosa, 2012, p. 169) nos primeiros anos do século XX no Rio de Janeiro, mas afirmou que esse movimento anarquista "nada acrescentou à nossa experiência literária" (p. 170), guardando somente a marca da história. Expressão literária de ideias novas importadas da Europa, o movimento circulava na pequena imprensa libertária da época $^{54}$. Barbosa constrói um quadro literário da época em que situa em lados opostos os “discípulos de Tosltói” Curvelo de Mendonça, Fábio Luz e Elísio de Carvalho, “esteta, bibliômano, tradutor de Oscar Wilde" (Barbosa, 2012, p. 171) e a geração anterior de Machado de Assis, dos frequentadores da Livraria Garnier e da Academia. Acrescenta ainda o grupo dos nefelibatas que também se opunham aos frequentadores da Garnier. Dele faziam parte figuras como Coelho Neto, João do Rio e Medeiros e Albuquerque.

É nesse contexto que Barbosa situou o aparecimento da revista Floreal, fundada por Lima Barreto em 1907. A crítica de Barreto recaia certamente sobre os nefelibatas, com uma simpatia pelo movimento libertário, mas, mesmo assim, sem uma participação ativa em qualquer movimento político, mesmo com o convite do amigo Pausílipo da Fonseca para colaborar com a imprensa libertária. Ainda que nesse universo de oposições, os limites ideológicos fossem muito mais maleáveis que no caso francês, como indica a curiosa figura de Elísio de Carvalho, a afinidade com os anarquistas e grupos libertários filia a obra de Barreto muito mais à voga dos romances tolstoístas do que ao nefelibatas e acadêmicos. Vejamos brevemente um pouco dos romances de Mendonça e Luz, para entender um pouco melhor as vicissitudes do caso brasileiro.

\footnotetext{
${ }^{53}$ Prado deixa anotado que o tolstoísmo como opção política, em 1914, já fora descartado pelos anarquistas no Congresso Internacional Antimilitarista de 1904, em Amsterdã.

${ }^{54}$ A criação da Universidade Popular em 1904 e o I Congresso Operário de 1906 fizeram parte dessa agitação dos grupos de esquerda do começo de século na capital fluminense.
} 
Em Regeneração, de Curvelo de Mendonça, romance que se passa a partir do ano de 1893, temos o personagem de Antonio, agricultor, "um homem rústico, de parca instrução" que tinha "uma espécie de doutrina econômica e religiosa" e lidera o movimento de transformação do engenho de Jerusalém, realizando ali o sonho de uma nova vida: “... uma solidariedade perfeita de relações e de trabalho com todos os futuros companheiros e auxiliares no cultivo das terras que ia administrar." (Mendonça, 1904, p. 20). Ao lado de José Doutor, encarregado dos cuidados com o local antes da chegada de Antonio, Jerusalém ganha a fama de ser como "um paiz de anjos em que o homem desafortunado podia encontrar um pouco de bôa vontade e de affecto misturados com o trabalho" (p. 41). Ricardo Moreira, o herdeiro das terras administradas por Antonio, também se encanta com o engenho, porém o seu tutor, dr. Fabrício Cardoso, não fíca satisfeito com o exíguo lucro obtido na produção, e demite Antonio do cargo. Na sua saída de Jerusalém, os moradores do engenho acompanham os passos do "apóstolo, o doutrinador e amigo" como numa procissão de fé: "Sem duvida não foi sem lagrimas sentidas e amargas saudades, que se moveu a columna immensa dos operarios acompanhada das esposas e dos filhos" (p. 65).

Apesar das resistências do tutor, o herdeiro Ricardo permanece ao lado de Antonio e acaba ganhando, com a doença do advogado, a posse das terras, para onde retorna com os trabalhadores evadidos de Jerusalém. O moço, "identificado com as idéas de Antonio", segue as premissas do tolstoísmo: "o desprendimento dos interesses materiais e o principio de não resistencia ao mal, desenvolvido e aconselhado por Tolstoi." (p. 88). A figura do padre Felismino, que "pregava um christianismo novo e singelo" está na base dos fundamentos sociais da regeneração social. A "pureza do christianismo primitivo" de Felismino é a base para Antonio, aproveitando o evangelho purificado, vencer as resistências e "propagar os principios do moderno communismo libertário" (p. 103). Com a posse de Jerusalém por Antônio, "a terra do sonho e da esperança", o "exercito" se põe em marcha rumo à desejada Jerusalém. A descrição do trajeto de volta de Antonio pelo narrador é emblemática do viés idílico da narrativa: "Tinha a figura fascinadora e magestosa dos conductores de povos, essas atalaias sublimes do pensamento humano, empenhadas na portentosa obra do melhoramento e da regeneração planetaria.” (p. 114). A natureza os recebe e uma tempestade faz o primeiro trabalho de limpeza "das paixões inferiores que a tinham devastado" (p. 150). 
Nesse romance de Curvelo de Mendonça, a figura do herói intelectual se confunde com o messianismo de Antonio, um misto de líder espiritual e intelectual dos trabalhadores de Jerusalém. Natureza e reflexão social correspondem à mesma síntese do personagem que Antonio simboliza, a força da terra e da personalidade acrescida das ideias de transformação social. Sem nenhuma grande luta social, a própria natureza antecipa, sinaliza e responde aos acontecimentos. A perspectiva narrativa idealista do narrador reduz o retrato do real a um olhar superficial e distanciado do que se passa no campo. Mas, ao mesmo tempo, sinaliza para a existência de um anseio por transformações a partir de reflexões sobre as ideias importadas da Europa. Temos aqui uma fusão entre um messianismo igualitário e um aporte das ideias libertárias em voga no período.

Toda essa temática aparece também em O Ideólogo, de Fábio Luz, de 1903, sendo o uso do termo regeneração uma constante não somente nesse romance, como em Os Emancipados, de 1906. Enquanto no romance de 1903, o foco se dá a partir da polarização entre dois indivíduos, o advogado inconformado com as injustiças sociais Anselmo e "o typo do médico impostor e philaucioso" Alcebíades, em 1906, o projeto avança com a família libertária de Auto Batista, sem deixar de lado a tensão entre dois indivíduos, ou dois mundos em oposição: o aprendiz do positivismo Auto Baptista e o jornalista de província e filho de chefe político, Philippe Arvellos.

No romance de 1903, os perfis de Anselmo e Alcebíades são descritos logo nos dois primeiros capítulos do livro, recurso bastante previsível do ponto de vista literário. O orgulho e a busca de glória e renome do médico são contrastados com as reflexões do advogado reformador. Como num típico roteiro melodramático, uma situação desencadeia as transformações tão esperadas por Anselmo: a chegada dos pais de Alcebíades ao Rio de Janeiro, com Elsa, na verdade fillha do médico com Mathilde, uma "mulatinha costureira". Essa nova condição, desconfortável para Alcebíades, é concomitante à doença e morte da esposa de Anselmo, Martha. A crise deflagra os novos acontecimentos: Elsa cuida devotamente de Anselmo que, depois de recuperado da traumática morte da esposa, retoma seu projeto de regeneração social, inspirado em Tolstoi e Antonio Conselheiro que "envagelisou sua religião nova, e organisou a seu modo a sua communa sem governo e sem potentados" (Luz, 1903, p. 153). Novamente, a mistura entre o social e o messiânico aparece na construção da base ideológica desse herói. 
O casamento de Anselmo e Elsa, previsível com a devoção da moça à recuperação do herói, acontece na virada do século, marcando simbolicamente a "nova vida no século XX" (Luz, 1903, p. 173). O advogado, apoiado agora pela felicidade conjugal que a nova esposa lhe propiciava, inicia os seus projetos de transformação, ao mesmo tempo em que Alcebíades, em crise de consciência pouco verossímil, revela seus sofrimentos com a mulher traidora e recusa sua herança em prol da filha bastarda. Novamente, como em Regeneração, a natureza faz o papel de pressagiadora dos novos tempos com o temporal que antecede "um formoso arco-íris" que "se desenhou vivaz na curva do firmamento".

Já o romance de 1906, Os Emancipados, é dividido em três partes. Na primeira, o passado, o narrador nos apresenta a origem e as características de Auto e Philippe, assim como na obra anterior, personagens em oposição. As famílias desses dois homens se encontram na primeira parte da obra e, enquanto os filhos de Auto circulam livremente pelo parque, os adoentados filhos de Philippe são cercados de cuidados excessivos pela mãe Jesuina. Alípio, filho de Philippe, fica gravemente adoentado depois do encontro. A mãe, extremamente religiosa, culpa a influência de Auto, chamando de feiticeiro o amigo do marido. O menino acaba se recuperando, mas sua irmã Eva falece logo depois de restabelecimento de Alípio.

A segunda parte do romance, presente, começa com uma epígrafe de Tolstoi de Souvenirs de Sébastopol, e é novamente a natureza que introduz a situação de crise iminente: "O céo estava ennevoado. As trovoadas eram frequentes nesse mez de Outubro; o ar pesado e abafadiço.” (Luz, 1906, p. 53). Nessa segunda parte, outro personagem é introduzido na narrativa. Trata-se de Firmino, um velho trabalhador que ao final da vida acaba obrigado a mendigar para alimentar a filha doente e os netos, depois de ter perdido um dos filhos numa batalha e não ter notícias do paradeiro da filha mais nova. Também como num enredo melodramático, essa filha desaparecida é Aurélia, segunda esposa de Philippe, que expulsa Firmino da casa rica onde ele viera pedir ajuda, sem reconhecer o pai no mendigo. No capítulo seguinte, conhecemos ainda Affonso Ferreira, rapaz rico que vive no subúrbio em concubinato com a jovem Dolores. É ele quem ajuda Firmino, quando esse perde sua filha nos braços, em busca de auxílio, e vê aí uma "missão a cumprir". Affonso acaba adotando os netos de Firmino, Julia e Paulo, e passam todos a morar com o rapaz e Dolores. 
Todas as famílias se misturam nessa segunda parte. Alípio e a madrasta Aurélia visitam a casa de Dolores e Affonso, conhecidos de Philippe. Esse é o evento deflagrador do reconhecimento melodramático no romance, pois ao mesmo tempo em que ocorre o reencontro entre filha e pai, Aurélia e Firmino, Alípio adere aos anseios comunitários de Affonso e Auto. Alípio se aproxima também dos filhos de Auto, Álvaro e Berta, ele um rapaz estudioso e ela sua companhia nas leituras de todas as obras de Kropothine ${ }^{55}$. Ainda que esse encontro enseje toda uma rede de transformação nos acontecimentos, o motivo da grande ruptura se dá, de fato, com a tentativa de Aurélia de trazer para a sua residência os seus sobrinhos, principalmente depois da morte do velho Firmino.

Dispondo de poder no mundo político, Philippe consegue a transferência de Auto para a zona fronteiriça, interdita a fortuna do filho Alípio, temendo a sua adesão às ideias libertárias de Auto e Affonso e é bem sucedido também com relação à guarda dos netos de Firmino. Contra o poder de Philippe, as famílias de Auto e Affonso decidem pela fuga para o campo, numa fazenda que se guiará "sob novos moldes" de convivência. A terceira e última parte, Futuro, iniciada com a epígrafe sem autoria: "O capital, social na sua origem, deve ser social no seu destino", já se inicia com a nova comunidade estabelecida. Ao final, novamente a natureza anuncia o futuro promissor, com a luz vespertina anunciado o fim do dia e "a Cidade Feliz, com cânticos e musica festejava os esponsaes de Paulo.” (Luz, 1906, p. 237). Enfim, o romance de 1906 realiza o que só se apresentava em germe em 1903, com O Ideólogo Anselmo.

Apesar da qualidade literária questionável dos romances e da ilegitimidade realista, é possível vislumbrar nessa vertente esquecida da prosa brasileira, nesse "ruralismo esclarecido", traços de afinidade com o nosso herói intelectual, sendo que no caso do herói tolstoiano algumas características acabam revelando peculiaridades do contexto brasileiro. Mais do que isso, não é possível deixar de lado a relevância dessa vertente esquecida no percurso literário de Lima Barreto, expressamente apoiador das causas libertárias e próximo de alguns de seus representantes.

Alguns dos traços desse tipo literário do herói intelectual: a fé na ideia como força no mundo real, a busca de um humanitarismo ideal e um sentimento de vergonha de uma burguesia usurpadora, enfim, uma consciência diante das desigualdades do

\footnotetext{
${ }^{55}$ Trataremos no último capítulo da segunda parte do que se convencionou chamar de socialismo utópico, ao qual se filia Kropothine.
} 
mundo social. A despeito do elemento urbano que caracteriza o herói intelectual, a diversidade temporal e ideológica apresentada por Brombert nos permite também ampliar a construção desse tipo em solo nacional para além dos limites das cidades. $\mathrm{O}$ que chama a atenção no herói tolstoiano do nosso ruralismo esclarecido é que apesar da oposição construída pelos narradores entre alguns personagens nos romances de Luz e Mendonça, como vimos anteriormente, a solução final dessas obras suprime o conflito e estabelece o novo mundo como um espaço isento de forças em oposição. É nesse sentido que Prado questiona a legitimidade desses romances que se arvoram revolucionários, mas mantêm intacta a estrutura agrária (e romanesca), sem explicitar as contradições da dura situação dos trabalhadores do campo. Somente no caso de Regeneração, já em 1914, é que a situação dos imigrantes, na figura do lombardo Fioretto, é mais problematizada e a exploração mais explicitada, de forma bem menos idílica, apesar da linguagem rebuscada do narrador. Segundo Prado, esse romance apontaria para uma perspectiva mais crítica, no tom das análises do ensaísmo ruralista pós-1930.

No que diz respeito à comparação com o herói intelectual, chama a atenção em todos esses romances a constante presença da tradição místico-religiosa, inspirada na figura de Antonio Conselheiro. Nesse sentido, o herói tolstoiano no Brasil se relaciona com o tipo do herói intelectual, como uma variação ou simplificação salvacionista, ainda ligado a uma estrutura narrativa dualista, aproximando-se do maniqueísmo melodramático. Se do ponto de vista ideológico, a legitimidade histórica desses romances anarquistas idílicos deve ser questionada, como propôs Prado, nas suas relações com a figura do herói intelectual, esses romances acrescentam algumas peculiaridades ao herói intelectual brasileiro.

Os limites entre as vertentes literárias e políticas no Brasil são, de fato, de difícil delimitação. De um lado, ainda que marcadas por um mundo maniqueísmo e de forte teor melodramático ${ }^{56}$, essas obras do "ruralismo esclarecido" não deixam de apontar para um incômodo de uma certa burguesia, atenta aos acontecimentos na Europa, que, diante das injustiças sociais observadas no seu entorno, propõe um novo mundo possível, ainda que deixando de lado as contradições da nossa realidade. De outro, a ausência de conflito na expressão literária dessa vertente continua, como no caso do formalismo parnasiano, tratando-se de um "reformismo pelo alto". Essa fagulha de

\footnotetext{
${ }^{56}$ Ver Almeida (2009).
} 
consciência que os heróis tolstoianos apresentam nesses romances não pode ser deixada de lado pela fragilidade literária, pois aponta para uma crise semelhante a que vivia o herói intelectual. Porém, diante de um mundo em crise social ou moral, eles apresentam projetos utópicos de igualdade social, sem considerar os paradoxos intrínsecos.

A presença da utopia de um futuro mais igualitário nesses romance tolstoístas no Brasil aponta para um incômodo que, certamente, só poderia existir em uma sociedade extremamente desigual. Se, por um lado, o "ruralismo esclarecido" idealiza a transformação, por outro, a proposição de uma utopia, nos moldes humanistas, o aproxima do herói intelectual. A partir destes romances, dois elementos se agregam a esta figura no caso brasileiro: a relevância do ambiente agrário, antecipando elementos dos romances ruralistas de 1930, e a incorporação do salvacionismo nos moldes de um Antonio Conselheiro, que guarda relações com o utopismo cético de Lima Barreto. Ainda que a obra limabarretiana seja infinitamente superior a esses representantes, as utopias, como no caso anatoliano, apontam para um sentimento de inconformismo em relação às injustiças do mundo, assim como para uma inquietação intelectual que não pode ser menosprezada naquele contexto.

Esse salvacionismo nos parece não somente ser um traço de um inconformismo, compartilhado por Lima Barreto, como também exerce influência sobre a sua perspectiva humanista. Porém, este traço com valor positivo nos tolstoístas, aparece problematizado na obra limabarretiana. À ingenuidade e harmonização destes romances, contrapomos a ironia e o conflito entre o eu e o mundo nos romances de Barreto. É nesse processo de internalização que o herói intelectual adquire a sua importância literária, sendo que a relação do personagem com a natureza e o espaço serão fundamentais nessa distinção, como veremos nos personagens citadinos de Lima Barreto e também de Anatole France. 


\section{3. "Poética" "57}

Uma questão vem à mente quando lemos obras literárias que visam a representação de momentos históricos, destacando a realidade social, cultural e política do ambiente em que viveram seus autores: o porquê da escolha de determinado gênero, no caso o romance, para a representação dessa realidade. Em se tratando de algumas épocas específicas, essa questão fica ainda mais presente, como é o caso da virada para o século XX, palco de uma crise no gênero. Segundo Jean-Yves Tadié, diante da crise, foram vários os remédios oferecidos pelos escritores franceses à época:

En 1891, dans l'Enquête sur l'évolution littéraire de Jules Huret, la crise du naturalisme depuis 1887 fait l'objet d'un diagnostic unanime, mais les remèdes proposés divergent: soit la poursuite du roman naturaliste, soit l'exploration du roman psychologique ou encore $\mathrm{du}$ roman social, soit le retour au divertissement. (Tadié, 2007, p. 604).

No universo francês, a solução de Anatole France segue, principalmente a partir de Les Opinions, na direção do "roman social". Desde o modelo flaubertiano de esvaziamento da ação, algumas rupturas já se desenhavam neste final do século XIX. Nas conversões católicas de Bloy e Huysmans, no psicologismo de Bourget, no nacionalismo literário de Barrès, ou na literatura social e sensual de France, os caminhos se bifurcam e se ampliam. Todos esses exemplos só corroboram a tese da crise do romance e, neste sentido, a definição de Tadié é perfeita para o gênero: "genre fourre-tout". O romance, portanto, absorve novas proposições formais, de conteúdo e ideológicas. As mudanças de rumo num mesmo autor também acontecem. Émile Zola, por exemplo, dá uma nova direção à sua obra nas suas últimas séries, um sentido mais “espiritualista” com Les Trois Villes, série de três romances escritos entre 1894 e 1898, e com a inacabada Les Quatre Évangiles, série composta entre 1899 e 1903.

O romance como "genre fourre-tout" se afirma como um gênero literário aberto a experimentações das mais diversas. Sua amplitude e pouca rigidez, em oposição às antigas poéticas com suas regras pouco flexíveis, aparece, no que tange a nossa pesquisa, nos prefácios de alguns livros de Lima Barreto e Anatole France, espécies de poéticas fugazes de suas criações. No caso de Barreto, as ideias contidas na apresentação da revista Floreal se repetem no artigo Amplius!, que introduz a coletânea

${ }^{57}$ Colocamos o termo poética entre aspas por não se tratar em geral de preceitos estéticos, mas principalmente de regras éticas. 
de contos intitulada Histórias e Sonhos (HS) ${ }^{58}$. Nesse texto, com "o intuito de esclarecer o que poderia haver de obscuro em certas passagens dos meus humildes trabalhos", Lima Barreto afirma estar respondendo a uma carta anônima, de tom cortês, que fazia sobre o Policarpo, "reparos sagazes e originais". Segundo o biógrafo Assis Barbosa, o romance Triste fim de Policarpo Quaresma", de 1915, recebeu um "verdadeiro coro de louvores" (Barbosa, 2012, p. 256), mas não faltaram as redundantes reservas dos policiais da gramática e do estilo, como criticava o próprio Lima Barreto.

O procedimento do qual o escritor fez uso nessa resposta seria o mesmo de outros momentos de sua obra: depois de elogiar o estilo cortês da missiva, ele atribuiu ao seu crítico as reprimendas usualmente direcionadas aos seus desafetos, o estilo pomposo, o louvor à Grécia, etc. Na carta, Barreto percebe e denuncia "uma forma excepcional de escrever, rica de vocábulos, cheia de ênfase e arrebiques", enquanto a ênfase da arte deveria ser para o criador de Isaías Caminha, não a realização da beleza estética, mas:

“... a comunhão dos homens de todas as raças e classes, fazendo que todos se compreendam, na infinita dor de serem humanos, e se entendam sob o açoite da vida, para maior glória e perfeição da humanidade". (HS, 2008, p. 10-11)

Para Lima Barreto, nenhum valor estético suplantaria o fim maior de aperfeiçoamento da humanidade por meio da comunhão dos homens. Nesse sentido, mais do que descolar o gênero de qualquer regra poética, também o fím da obra fica isento de uma apreciação estética. É possível pensar a partir das palavras do escritor em uma valoração dos elementos éticos em detrimento dos estéticos na obra literária. A comunhão, a compreensão, a dor, a humanidade, todos estão à frente das regras literárias cristalizadas na figura de um João Ribeiro, assim como na de Osório Duque Estrada, citado por Barbosa como autor das reprimendas à escrita informal de Barreto. Há uma inversão de princípios e fins na obra de arte, ela não segue nenhuma regra poética rígida, nem deve se destinar a uma apreciação puramente estética ${ }^{60}$.

${ }^{58}$ O artigo original foi publicado em $A$ época, em 1916, como resposta às críticas feitas ao romance Triste fim de Policarpo Quaresma. A coletânea de contos Histórias e Sonhos foi publicada em 1920 pela Editora de Gianlorenzo Shcettino e em 1952 pela Editora Brasileira.

${ }^{59}$ Publicado em 1911 em folhetins do Jornal do Commercio, teve sua primeira edição em livro em 1915. A editora O Livro de Bolso publicou uma edição em 1943, seguida por uma edição da Gráfica Editôra Brasileira, de 1948 e outra da Mérito, de 1948. Não analisaremos este romance na tese, mas para qualquer referência utilizaremos a edição da Brasiliense, de 1956.

${ }^{60} \mathrm{O}$ escritor exige também do crítico novas ferramentas de análise. 
O segundo ponto da suposta crítica à qual Barreto se opõe é a insistência na Grécia como ideal da arte. Voltamos à seara dos princípios: nenhuma regra longínqua no tempo e no espaço pode servir de base para a sua criação artística. Não desprovido de humor, o escritor é enfático em sua implicância com a Grécia: “implico solenemente com os nossos cloróticos gregos da Barra da Corda e pançudos helenos da praia do Flamengo" (HS, 2008, p. 07). A beleza buscada na arte grega impediria a realização do "nosso ideal, aquele que está na nossa consciência, vivo no fundo de nós mesmos" (p. 09). No que diz respeito a alusão ao ideal grego, parece-nos claro que a crítica se dirige a Coelho Neto, mas poderia perfeitamente ser atribuída a Afrânio Peixoto e sua literatura como "sorriso da sociedade". Nesta segunda crítica, lê-se a compreensão da arte ligada a uma inspiração cotidiana, próxima às questões de seu tempo.

A terceira questão que Barreto discute com o suposto crítico é temática. Segundo a crítica, era esperado que o romance tratasse ou tivesse como foco um caso de amor, o que não se dá em nenhum romance de Lima Barreto. Numa crítica velada ao romance $\grave{a}$ clef de Afrânio Peixoto, Barreto responde que a questão do amor "nunca foi primordial no romance" e que mesmo nos grandes mestres modernos, entre os quais cita Balzac e Dostoiévski, o amor fica em segundo plano. Mais uma vez, trata-se aqui de um distanciamento das regras de composição, desta vez no que diz respeito aos temas dos romances. Deste ponto de vista temático, Lima Barreto marca a sua filiação, nas referências a Balzac e Dostoiévski, a uma arte cujo foco está na observação e descrição da sociedade como um todo, uma compreensão ampla da temática romanesca e com forte influência social.

Também a carta o teria acusado de "empregar processos do jornalismo" (p. 11) nos romances, principalmente em Isaías Caminha. Barreto responde à crítica afirmando que "os chamados processos do jornalismo vieram do romance", e mesmo que no seu romance se dê o caminho inverso, se isso contribuísse para a comunicação com o leitor, não haveria nenhum problema em tal procedimento. Esse caminho de mão dupla entre jornalismo e literatura aponta para outra característica permanente da obra do autor que é a redução dos excessos estilísticos do literato, uma franca oposição à escrita rebuscada e bacharelesca de grande parte dos escritores de sua época. É fundamental notar que nem nos procedimentos, nem nos fins da literatura, nem na temática, o autor trata de questões estéticas, mas sim de questões de fundo ideológico. A literatura é, antes de tudo, um modo de estar no mundo. 
Também no prefácio de Isaías Caminha, a questão do gênero romance é tratada, só que dessa vez o escritor responde a uma crítica positiva de José Veríssimo, recuperando para este fim o prefácio original que havia sido publicado na revista Floreal. Assinado pelo narrador Isaías Caminha, com um pequeno acréscimo do autor Lima Barreto, Isaías diz que não tinha sido sua intenção com o livro fazer "obra d'arte, romance" (IC, 1956, p. 42). A motivação inicial, assim como a grande parte dos elementos da obra, encontra-se descolada dos modelos formais. Isaías conta que sua primeira inspiração para o livro partiu de um texto que lera em uma revista nacional, na qual o autor fazia "multiplicadas considerações desfavoráveis à natureza da inteligência das pessoas do meu nascimento" (p. 40), ou seja, aos negros.

Nesse texto, de autoria não revelada, o autor notara a defasagem entre a infância e a vida adulta dos negros, sendo a "pujança das primeiras idades" desmentida no fracasso da maturidade. O narrador-personagem então se defende, afirmando que a "essência explicadora" (p. 41) das acusações não estaria no indivíduo, mas na estrutura social. Esse indivíduo, que é o próprio herói do romance, seria uma vítima da sociedade: este personagem, "desprovido de tudo, de família, de afetos, de simpatias, de fortuna" (p. 42), tem o seu fracasso justificado não na sua trajetória individual, mas na injusta sociedade brasileira. Não somente o fim da arte é social, como também organização dessa sociedade influencia no destino de seus personagens. O social determinaria, assim, a origem e o fim da obra

As questões propriamente estéticas aparecem de modo sorrateiro nestes prefácios. Poderíamos destacar três aspectos que se repetem nas oposições criadas nos prefácios: não escrever em estilo rebuscado, não se ater a modelos antigos e distantes e não se pautar pelo romance romântico, cujo principal foco seria a história de amor. As questões estéticas residem nos elementos externos às obras. O estilo rebuscado, os modelos antigos e a temática romântica representam o mundo literário consagrado, ao qual Lima Barreto se opõe. As questões estéticas só adquirem relevância diante do primado ético do escritor sincero e comprometido com a escrita. Estes fundamentos estético-sociais funcionam, assim, como fundamentos de um manifesto da literatura militante de Lima Barreto, diante da qual o dever de "escritores sinceros e honestos" é, deixando de lado as velhas regras e a disciplina dos gêneros:

“... aproveitar de cada um deles (dos gêneros) o que puder e procurar, conforme a inspiração própria, para tentar reformar certas usanças, sugerir dúvidas, levantar julgamentos adormecidos, difundir as nossas 
grandes e altas emoções em face do mundo e do sofrimento dos homens, para soldar, ligar a humanidade em uma maior, em que caibam todas, pela revelação das almas individuais e de que elas têm em comum e dependente entre si. (HS, 2008, p. 10)

As velhas regras e a fixação dos gêneros são deixadas de lado em prol do seu projeto militante. A vida vem antes da arte na teoria estética limabarretiana. Ao se defender das críticas, Barreto afirma então uma nova literatura, uma literatura militante que deve usar de todos os meios para unir os homens. Porém, para a realização de tal alto fim de ligar a humanidade, Barreto recorre tanto ao diretor da Revue des Deux Mondes, Ferdinand Brunetière - cuja crítica conservadora é influenciada pelas regras poéticas e se opõe ao impressionismo anatoliano - que teria lhe dito que "todos os meios são bons quando o fim é alto" (HS, 2008, p. 11), como ao evangelho: "No mundo, não há certezas, nem mesmo em geometria; e, se alguma há, é aquela que está nos evangelhos: amai-vos uns aos outros" (p. 12).

Cita ainda o exemplo de São Francisco Xavier e de todos aqueles que "separados em castas hostis, entre malaios ferozes e pérfidos, entre japoneses que se guerreiam feudalmente", todos deveriam ter a "divisa do santo: 'Amplius! Amplius!' Sim; sempre mais longe! ". O interessante é que de um lado, Barreto se justifica com os altos fins do conservador Brunetière, fins certamente poéticos, de outro, com um salvacionismo religioso, a partir de uma lei universal cristã e do exemplo dos santos. A coerência de sua "teoria estética" esbarra na escolha das suas fontes de fundamentação, mas também nos revela um pouco mais sobre a figura paradoxal do autor e do leitor Lima Barreto.

Essa oscilação ideológica das fontes às quais Lima Barreto recorre aponta de um lado, para um leitor atento às informações vindas de Paris, dos principais representantes da crítica literária francesa, assim como das ideias correntes do socialismo e do tolstoísmo europeus, apesar de nunca ter estado no velho continente. De outro lado, são no mínimo paradoxais. No quadro literário francês, Brunetière e France ocupam, como vimos, posições antagônicas, e enquanto o primeiro tende para uma posição mais à direita, a de France (como a de Barreto) se inclina mais em direção às correntes de esquerda. A posição ideológica de Barreto, consideradas as suas múltiplas referências, traz à tona recorrentemente essa duplicidade. A maleabilidade ideológica que vimos nos tolstoítas parece se reproduzir eventualmente na "poética" limabarretiana. A mesma dubiedade aparece na relação com Anatole France, lido no Brasil como o sensualista, mas figurando na base da literatura militante de Barreto. A solução para esse paradoxo não nos parece possível, pois é exatamente a posição hors et là de ambos que suscita a 
dubiedade. O ajustamento ideológico de Barreto não segue necessariamente a lógica da exclusão do conflito. Ele se justifica pela leitura errática das referências às quais recorre, uma vez que se realiza somente no plano da palavra, nunca da ação.

Outro aspecto tratado acerca do herói intelectual, a relação entre o criador e a criatura, também aparece no prefácio a Isaías Caminha. A presença autoral na construção de uma "poética" prefacial é sem dúvida relevante. Barreto afirma no prefácio de Isaías Caminha que começara a publicar as recordações do amigo na Floreal, "uma pequena revista que editei” (IC, 1956, p. 39), em 1907, com um pequeno prefácio do autor. A história de publicação do romance de Barreto é transposta para o percurso da obra de Caminha. O oferecimento de Antônio Noronha Santos, amigo de Lima Barreto, para buscar um editor em Portugal, foi, de fato, o que se deu na publicação do livro de estreia do autor. Antônio Noronha foi o responsável por levar os originais do romance, com uma carta de João Pereira Barreto - poeta do grupo da Floreal que publicara seu livro de poesias na Livraria Clássica, de Lisboa -, para o sr. A.M. Teixeira. É essa mesma história que aparece no itinerário de publicação do romance do amigo Isaías, e, na tentativa de se distanciar ou de dissimular, Lima Barreto agradece a todos os envolvidos em nome do Isaías: "A todos três, não posso, em nome do meu querido Isaías, deixar de agradecer-lhes mais uma vez o serviço que prestaram à obra".

Um aspecto que confunde o leitor no prefácio é a crítica de José Veríssimo. Se a obra é de autoria de Isaías, "errou” Barreto a transcrever as palavras do crítico, dirigidas ao "senhor Lima Barreto"? (p. 40). Veríssimo elogia a singularidade da revista Floreal, especialmente no romance de Barreto, que ele afirma ter sido escrito com "simplicidade e sobriedade". Ainda que não se possa determinar com certeza se o "erro" foi por descuido ou proposital, o fato é que o paralelismo entre a história de Barreto e a de Isaías consolidará este narrador como um dos pseudônimos do autor ${ }^{61}$. Particularmente no prefácio de estreia, juntamente com a justificação da obra, com a explicação das razões da escolha do gênero romance ou na defesa de uma "póetica" do engajamento, nesse prefácio está em jogo a construção de um pseudônimo, um representante legítimo o suficiente para iniciar o grande empreendimento literário pelo qual o escritor anseia.

${ }^{61}$ Um estudo dos pseudônimos e características dos personagens em Lima Barreto, que assinou também como Dr.Bogóloff, está ainda por ser feito. Barbosa cita o artigo "Palavras de um snob anarquista" sob a assinatura de Caminha e afirma que o escritor assinara a princípio como Bogóloff no jornal esquerdista Lanterna, retirando depois a máscara e assumindo a autoria de Lima Barreto. 
Por isso, a proximidade confusa entre o escritor Lima Barreto e o narrador Isaías Caminha.

Mas, ao final do prefácio, o escritor realiza um movimento de separação deste narrador, temporal e existencial. Ele conta que dez anos depois Isaías não se incomodava mais com o livro, pois perdera muito de sua amargura. Frequentando o Municipal, as casas de chá, o "footing domingueiro", Isaías enviuvara, enriquecera e se tornara deputado. O escritor finaliza então com um "Basta", descolando-se assim da sua criação que toma corpo próprio e segue seu próprio caminho.

De forma mais professoral, também o personagem de Jacques Tournebroche, narrador de La Rotissêrie, apresenta o seu percurso junto ao mestre Coignard ${ }^{62}$. Também, por meio desse personagem-narrador, o autor France enuncia a sua compreensão da obra de arte. Uma das questões apresentadas por Tournebroche diz respeito à verossimilhança de sua experiência com o mestre Coignard. Ao recordá-la, ele afirma: “je doute moi-même si je n'ai pas rêvé” (RRP, 1987, p. 03). Essa dúvida que, a princípio, parece referir-se somente à existência ou não da experiência vivida, amplia-se, nas considerações de Tournebroche, para uma compreensão mais ampla que se afina com a perspectiva autoral: assim como para Anatole France, também seu personagem concebe a vida como ilusão.

Tournebroche conta que conhecera um "kabbaliste gascon", de quem ele tinha tido o cuidado de reproduzir por escrito os discursos sobre a magia e as ciências ocultas. Diante desse universo místico, a desconfiança no cabalista se amplia na pena de Tournebroche, que propõe então um estado geral de desconfiança e ceticismo que vai guiar o pensamento do narrador por toda a obra. Isto porque o pouco que ele aprendera da arte do cabalista, o fizera "véhémentement soupçonner que tout en est illusion, abus et vanité" (p. 03). Este princípio basico do ceticismo é compartilhado entre o narrador e o escritor.

Apesar de ter escolhido um religioso e seu discípulo como espécies de porteparoles, o autor France compartilha com suas criações diversas posições. Tournebroche descreve seu mestre como um "homme plein de Science et de piété" (p. 04), mistura peculiar entre o mundano e o religioso, cuja concepção de vida se vale de um estado de suspeição que se descola dos dogmatismos religiosos e se afina com o ceticismo

\footnotetext{
${ }^{62}$ Neste primeiro dos dois romances centrados na figura de Jérôme Coignard, La Rôtisserie e Les Opinions, não existe propriamente um prefácio, mas o narrador Jacques Tournebroche apresenta a obra no primeiro capítulo do romance, no qual conta as suas aventuras com o mestre Coignard.
} 
anatoliano. Este santo pícaro, em todas as contradições que a união dos dois termos enseja, é uma figura central para compreender as opções (e incoerências) do próprio escritor Anatole France. A ilusão e a dúvida fazem parte da "poética" anatoliana; a primeira se converte na obra literária em defesa da imaginação e a segunda, nas recorrentes digressões de seus céticos narradores.

Já o prefácio da obra posterior ${ }^{63}$, Les Opinions, assinado por Anatole France, elogia a obra do discípulo pelo "portrait plein de vie et tout empreint d'une amoureuse fidélité" (OJC,1987, p. 207). Ele nos deixou, segundo France, "un chef-d'oeuvre”. O elogio de France corrobora ainda elementos da escrita de Tournebroche no livro anterior: a linguagem simples, coerente e honesta, fundada em suas próprias experiências, além da premissa da suspeição e ilusão à qual nos referimos acima. Dirigindo-se ao leitor, France continua, nesse prefácio, a elucidar sua compreensão da literatura, não sem ironia e doses de erudição excessiva. Pelo que nos conta, Tournebroche não chegara a publicar as notas que fizera sobre a vida de seu mestre Coignard. A razão seria, para o prefaciador France, a sua consciência do valor da glória literária, “c'est-à-dire autant comme rien" (p.208).

Nesta dissolução valorativa da consagração literária, Anatole France antecipa seu próprio ostracismo, ao afirmar que toda a obra está "sujette à toutes les vicissitudes et dépendant de circonstances en elles-mêmes petites et misérables". Da posteridade, portanto, não se poderia esperar muito e Tournebroche sabia desse risco. Tournebroche pressentia, como France, que "l'avenir, étranger à nos querelles, nous accorderait son indifférence à défaut de justice". O esquecimento da posteridade deveria ser aguardado por todos, já que ela “nous réunira dans l'oubli et répandra sur nous tous l'égalité paisible du silence". Dramático e premonitório, o tom do prefácio não se deixa levar pelo fatalismo, já que toda e qualquer obra, mesmo as obras primas nunca serão compreendidas no seu sentido original, pois "l'avenir nous deviendra tout à fait étranger" (p. 209).

Porém, a modéstia do escritor é somente um manto para o seu orgulho, pois a glória de um homem medíocre não ofende ninguém, "mais il y a dans le talent une insolence qui s'expie par les haines sourdes et les calomnies profondes". O elogio a Jacques Tournebroche no prefácio de Anatole France vem exatamente da sua renúncia

\footnotetext{
${ }^{63}$ Nessa obra, é o próprio autor Anatole France que escreve um prefácio para apresentar a obra, no qual conta a origem do livro e elogia o trabalho anterior de Tournebroche.
} 
consciente ao "pénible honneur d'irriter par un éloquent écrit la foule des sots et des méchants". O bom senso de Tournebroche vem da sua consciência da insuficiência de suas palavras diante dos seus contemporâneos e da posteridade. Ao mesmo tempo, há nessa modéstia algo do orgulho do escritor no elogio ao narrador Tournebroche.

Também no prefácio de Gonzaga de $\operatorname{Sá}^{64}$, há essa passagem de autoria entre o escritor e o narrador. Diz Barreto que seu "antigo colega de escola, e, hoje, de ofício, Augusto Machado" (GS, 1956, p. 27), encarregou-o de publicar a sua "pequena obra". A princípio, Machado havia lhe pedido uma revisão, mas Lima Barreto, não encontrando nada para retocar, questiona o gênero da obra já que, "não me pareceu de rigor a classificação de biografia que o meu amigo Machado lhe deu". A análise que se segue trata das ausências na obra das características de uma biografia, segundo o escritor. Para Lima Barreto, faltam à obra: "a rigorosa exatidão de certos dados, a explanação minuciosa de algumas passagens da vida do principal personagem e as datas indispensáveis em trabalho que queira ser classificado de tal forma”. Além disso, Barreto acrescenta que, na obra do amigo Machado, aparece demais a pessoa do autor, tratando ele mais de si próprio do que de seu herói, Gonzaga de Sá.

Parece-nos claro que a crítica à classificação biográfica é uma ironia do escritor Lima Barreto antecipando e justificando as censuras à sua obra. Além do antigo estigma do roman à clef do romance de estreia, há também uma busca de precisão que não poderia estar mais distante da escrita limabarretiana. Há também nesta discussão sobre o gênero biografia, a retomada das premissas desenvolvidas em Amplius!. Lá, como vimos, o escritor sugeriu que o gênero não é relevante em si, mas que a escolha do modelo deveria estar afinada, antes de tudo, com o fim último da literatura militante, o de ligar a humanidade.

Outro elemento que surge da mistura entre perspectiva autoral e narrativa nos dois autores é parte da premissa anatoliana da limitação existencial do ato da escrita. Tournebroche afirma que é somente das lembranças de sua vida, e não das suas leituras, que ele tira todas as suas riquezas. Machado, por sua vez, fala de si mesmo ao escrever sobre um outro. Não seria essa limitação existencial assumida pelos dois autores a marca de uma "poética" existencial, característica que muitas vezes confunde criador e criatura? Não estaria esta perspectiva afinada com o fim maior da literatura militante,

64 Consideramos o prefácio a Advertência, datada de abril de 1918 por Lima Barreto, apresentando a obra do narrador da obra, e a Explicação Necessária, assinada por Augusto Machado em oito de outubro de 1906. 
unir a humanidade nas limitações existenciais de cada um e de todos? Trata-s,e sem dúvida, da mesma orientação da ética sobre a estética que comentamos anteriormente nos prefácios limabarretianos. É o escritor como ser humano que busca a comunicação pela literatura, nunca o esteta da palavra. Disto resulta sua força de embate, não apenas as suas contradições e limitações.

$\mathrm{Na}$ base dos romances de Lima Barreto e Anatole France não é possível encontrar regras estéticas, mas sim regras éticas de composição. A simplicidade da escrita se traduz na preocupação com a comunicação da obra. As incertezas figuram como antídoto às generalizações e tendências totalizantes de escritas nacionalistas e puramente salvacionistas de alguns escritores contemporâneos nos contextos brasileiro e francês. A posição desses narradores está limitada ao mesmo tempo por uma compreensão de mundo mais ampla que as individualidades e pelos limites existenciais de cada experiência particular. Coignard é um exemplo para Tournebroche; ele é um mestre formado no melhor modelo humanista. O modelo de Machado é o próprio Gonzaga de Sá, ainda que isento do aspecto professoral da relação entre Tournebroche e Coignard. O modelo humanista é comum nas duas obras, seja na figura do jocoso Coignard ou do melancólico Gonzaga. Existem, porém, distinções. A oposição do narrador Augusto Machado ao modelo biográfico de Pelino Guedes ${ }^{65}$ se configura como um elemento particular do contexto de Lima Barreto, de oposição ao ambiente literário e político de sua época.

De um lado, portanto, as semelhanças entre Barreto e France estão ligadas a uma forma existencial de escrita de prevalência ética, cujos elementos encontramos na "poética" prefacial de ambos. De outro, observamos uma distinção quanto ao modelo de escrita. Em Barreto, a ruptura com uma estética anterior é a forma encontrada pelo autor, desde o romance de estreia, para se opor aos literatos. Nesse sentido, as palavras sarcásticas de Augusto Machado, na introdução da obra, nos revelam um escritor que busca se descolar de uma tradição, enquanto afirma, ironicamente, o intuito da imitação dos modelos grego e burocrático (Plutarco e doutor Pelino):

Não sei grego nem latim, não li a gramática do Senhor Cândido de Lago, nunca pus uma casaca e não consegui até hoje conversar cinco

${ }^{65}$ Pelino Guedes era o diretor-geral da Diretoria da Justiça e foi o responsável pelo processo de aposentadoria do pai de Lima Barreto. O escritor fez dessa figura, segundo Francisco de Assis Barbosa, "o tipo clássico do funcionário público que vive a bajular os poderosos e a oprimir os fracos" (Barbosa, 2012, p. 133). Ele é um dos modelos de biografia citado no prefácio. 
minutos com um diplomata bem talhado; sigo, entretanto, o exemplo do severo e saudoso lente de Mecânica da Escola Politécinca, doutor Licínio Cardoso, que estudou longos anos a alta matemática para curar pela homeopatia.

$[\ldots]$

Atirando-me aos azares da publicação de um opúsculo aliteratado, pode ser que seja feliz, como o meu inestimável lente o foi na homeopatia; pode ser que não e leve algumas descomposturas. Embora desagradáveis, as descalçadeiras dar-me-ão alento para viver, coisa que me vai faltando dentro de mim mesmo.

É um estimulante que procuro, e uma imitação que tento. Plutarco e o doutor Pelino, mestres ambos no gênero, hão de perdoar esse meu plebeu intento, de querer transformar tão excelso gênero de literatura moral - a biografia - em específico de botica.

Perdoem-me! (GS, 1956, p. 30-31)

Os modelos são dúbios; o narrador, claramente irônico. A posição deste é de oposição em relação à tradição. De um lado Plutarco e a busca de inspiração alhures, já criticada na inspiração grega dos literatos, que se convertirá em sátira no decorrer da obra limabarretiana. De outro, o dr. Pelino, o exemplo do tipo burocrata execrado pelo autor, uma peculiaridade do escritor Lima Barreto em relação aos modelos consagrados. Mas a frase reveladora é: "É um estimulante que procuro, e uma imitação que tento". A motivação da obra limabarretiana, o seu estímulo, está, como vimos, fora da obra. Mas, o seu projeto é estritamente literário. $\mathrm{Na}$ imitação que tenta, estão suas influências e inspirações, que, muitas vezes, em sua leitura errática, vêm das mais diversas matizes ideológicas. No que diz respeito à relação com a escrita militante anatoliana, o que percebemos é uma compreensão compartilhada por Lima Barreto e Anatole France, na qual a vida se confunde com a literatura. A dúvida existencial de France e a preponderância ética de Barreto apontam para uma literatura de comprometimento, profundamente humanista, como os seus mestres. 


\section{Parte 2 : Romances}

“A ironia é a mais alta forma de sinceridade." (Enrique Vila-Matas)

“Vivre c'est se transformer" (Anatole France)

"Every writer is the son of his age” (Lukács)

"Gonzaga de Sá é um velho irmão de M. Bergeret e do Conselheiro Aires, que encara o mundo sem preconceitos, com um amor entranhado pelos humildes e sofredores, e uma íntima queda pelo paradoxo engenhoso"

(Tristão de Ataíde)

“L'avenir est un lieu commode pour $y$ mettre des songes" (Jérôme Coignard) 


\section{Um leitor-modelo}

Em recente estudo sobre Anatole France, Édith Tendron (1995) tratou do lado enganador da escrita anatoliana. Segundo Tendron, mesmo nos livros mais declaradamente autobiográficos, como Le Livre de mon ami ${ }^{66}$ (Le Livre), de 1885, o narrador faz da imaginação um elemento não somente de construção da narrativa, como também, de abertura interpretativa para o leitor. O lado enganador do escritor está diretamente ligado à subjetividade do leitor. Tendron cita um trecho de Le Jardin d'Épicure ${ }^{67}$, de 1894, espécie de livro de máximas, onde há uma reflexão que trata da posição do leitor na obra: "Quand on lit un livre, on le lit comme on veut, on en lit ou plutôt on y lit ce qu'on veut. Le livre laisse tout à faire à l'imagination ..." (JE, 1923, p. 17). O livro é "une suite de petits signes" e cabe ao leitor "à tirer lui-même les formes, les couleurs et les sentiments auxquels ces signes correspondent".

Sob este ponto de vista, a leitura que Barreto faz da obra anatoliana não é uma criação despropositada, mas uma recriação prevista na abertura que a própria obra enseja. Se em solo brasileiro, foi o senso comum anatoliano da "ironia e piedade" que inspirou os nossos literatos, como sugere o título do livro homônimo de Olavo Bilac ${ }^{68}$, a leitura de Barreto se destaca dessa corrente interpretativa, de forma autônoma e original. Mas, de onde Barreto, tirou a sua interpretação? Onde ele teria visto a militância nas palavras do escritor francês?

Sobre a concepção de ironia, Pierre Schoentjes (2001) enumera quatro sentidos dominantes para o termo, cada um deles ligado a uma finalidade. Dos tipos de ironia descritos por Schoentjes, a ironia socrática e a verbal são as duas formas que mais dialogam com a obra de Anatole France. No caso dos romances em questão, a ironia verbal é a que mais se aproxima das características do nosso objeto. Nela, o sentido

${ }^{66}$ Esse romance autobiográfico foi publicado em jornais e revistas, entre 1879 e 1885 . A edição em livro saiu em março de 1885 pela Calmann-Lévy, tendo sido anteriormente anunciada no L'Univers Illustré, de novembro de 1884 com o título Les Aventures de Pierre Nozière. Em 1901, é publicada uma nova edição corrigida pelo autor. Integra a edição da Pléiade.

${ }^{67}$ Essa obra não consta na edição da Pléiade, acessamos uma versão online da edição de 1923.

${ }^{68}$ Ver BILAC (1923). Curiosamente, no livro de Bilac, o nome de Anatole Frane é mencionado uma só vez na crônica "Cantoamor”. A definição dos dois termos está em Le Jardin d'Épicure: “L'Ironie et la Pitié sont deux bonnes conseillères; l'une, en souriant, nous rend la vie aimable; l'autre, qui pleure, nous la rend sacrée. L'Ironie que j'invoque n'est point cruelle. Elle ne raille ni l'amour, ni la beauté. Elle est douce et bienveillante. Son rire calme la colère, et c'est elle qui nous enseigne à nous moquer des méchants et des sots, que nous pouvions, sans elle, avoir la faiblesse de haïr." (France, 1923, p. 43) 
expresso no texto está em oposição ao real, sendo sua intenção de convencimento, pois diferentemente da ironia socrática, não supõe o contraditório.

Comecemos pela ironia em La Rôtisserie. Neste romance das aventuras de Coignard e de seu discípulo Tournebroche, há um trecho sobre o personagem do capuchinho $^{69}$ Ange - alvo predileto da ironia de Jérôme Coignard -, no qual os elementos da ironia que perpassam toda a obra de France já estão presentes, o que nos parece estar na base da compreensão limabarretiana. Na cena do capuchinho, o narrador Tournebroche, ao sair da rotisseria, escuta uma voz grave e profunda cantando:

"Et je ne tardai pas à voir, du côté d'ou venait cette voix, frère Ange qui, son bissac ballant sur l'épaule, et tenant par la taille Catherine la dentellière, marchait dans l'ombre d'un pas chancelant et triomphal, faisant jaillir sous ses sandales l'eau du ruisseau en magnifiques gerbes de boue qui semblaient célébrer sa gloire crapuleuse, comme les bassins de Versailles font jouer leurs machines en l'honneur des rois." (France, 1987, p. 53, grifos nossos)

Em primeiro lugar, chama a atenção o uso dos dois oxímoros presentes na frase: "pas chancelant et triomphal" (passo hesitante e triunfal) e "gloire crapuleuse" (glória crapulosa, imoral, libertina). A dúvida do leitor se instaura a partir destes sentidos em oposição, pois a leitura deles coloca o sentido geral em suspeição, causando uma espécie de estranhamento no interlocutor. O conceito de estranhamento (ostraniene) ${ }^{70}$, cunhado por Chklovski a partir de um texto de Liev Tolstói, foi apropriado pela estética da recepção de Wolfgang Iser, particularmente para o ato de imaginação contido no ato da leitura. Para Iser, o texto literário contém não somente um grau interno de indeterminação (Unbestimmtheit), como essa indeterminação deve ser preenchida no ato da leitura. Para o teórico da recepção, “a peculiaridade do texto literário está em uma oscilação singular entre o mundo dos objetos reais e a experiência do leitor" (Iser apud Lima, 2002, p. 27). O conceito de leitor-modelo de Umberto Eco segue também a linha de Iser, sendo o leitor "uma espécie de tipo ideal que o texto não só prevê como colaborador, mas ainda procura criar" (Eco, 1994, p.15).

A partir, portanto, desta primeira suspeição em relação aos oxímoros, partiremos para a interpretação mais ampla do trecho, inspirada tanto pela reivindicação de uma interpretação criativa, na linha proposta pelo próprio France, como no ensejo de seguir o

\footnotetext{
${ }^{69} \mathrm{O}$ capuchinho pertence à ordem religiosa dos franciscanos, enquanto o abade é da ordem beneditina.

70 Procedimento traduzido também como singularização, que é utilizado para "libertar a percepção dos automatismos" (Chklovski apud Eikhenbaum et.al., 1971, p.54).
} 
olhar do leitor Barreto. Vejamos, a princípio, como é construída a figura do capuchinho Ange no romance para examinar melhor o trecho transcrito acima. Na primeira cena do romance, o capuchinho aparece dando aula a Tournebroche; é ele quem ensina o menino a ler. Nela, o abade Coignard chega à rotisseria do pai de Tournebroche, Léonard Ménétrier, e se espanta com a constatação de que o próprio capuchino soubesse ler. Ange sai de cena, mas logo ficamos sabendo que ele, já embriagado, envolvera-se numa briga pela bela Catherine, a rendeira ("la dentellière"). Primeiro, o capuchinho é alvo de deboche por Coignard e, na sequência, o narrador Tournebroche nos revela a cena de Ange como personagem brigão e mulherengo, contada por Catherine, que vem pedir ajuda para o capuchinho.

Diante dessa descrição, o próprio nome do personagem, anjo, já se configura como uma ironia do narrador. Uma inversão do sentido real que o narrador confere ao personagem. A sua primeira aparição no romance inaugura a imagem que vai sendo desenhada do personagem no decorrer do livro: um grande beberrão constantemente envolvido em confusões. Não que seja somente o capuchinho o alvo das reprimendas do narrador, pois nenhum dos outros personagens é exatamente um santo. Mas, enquanto as aventuras de Coignard são, na maioria das vezes, contadas por ele mesmo ou por seu discípulo e admirador, as peripécias do capuchinho nunca saem da boca do próprio Ange. O outro ironizado não tem voz.

A construção do personagem do capuchinho, a lógica particular criada pelo narrador, difere bastante da cumplicidade construída entre Coignard e o leitor, esse homem que chega como uma aparição à rotisseria de Ménétrier, um homem "assez noble". De outro lado, Ange é o "capucin indigne". Curioso é que Coignard não difere muito de Ange no que diz respeito às mulheres e aventuras. O que difere é a voz do narrador em relação a esses dois personagens: o abade pode contar suas próprias aventuras ao dono da rotisseria que o considera, a despeito dos casos amorosos e das prisões, um "brave homme". A vida de Coignard, "moins doctorable que picaresque", não é uma vergonha como a de Ange, apesar de ambos levarem uma existência errante e à margem das leis religiosas.

Mesmo que pareça natural a cumplicidade com Coignard, pela centralidade que o personagem toma na narrativa - o que era para ser uma história das aventuras de Tournebroche se transforma nas aventuras do abade -, os recursos narrativos de dar voz a Coignard e de esconder Ange na fala dos outros, transformam o capuchinho no alvo 
perfeito das ironias do narrador. Segue-se a isso o rebaixamento de tudo que se compara ao capuchinho, como é o caso da lama que sai de suas sandálias. Os deméritos de Ange são postos em relevo pela retirada da voz do personagem, enquanto o mérito de Coignard vem da atribuição do papel de narrador ao seu discípulo e à voz dada a ele no relato de suas próprias peripécias. Ao rebaixamento do capuchinho equivale a elevação do herói intelectual. A ironia em relação a Ange não se deve a sua moralidade ${ }^{71}$ questionável, mas a sua incapacidade reflexiva.

No trecho do capuchinho, essa incapacidade reflexiva aparece simbolizada na descrição de Tournebroche: o irmão Ange, cantando, com seu saco nas costas e puxando Catherine pela roupa, andava na penumbra ("dans l'ombre"). O termo "ombre" nos permite algumas inferências no caso de Ange. Espaço privado de luz, trata-se, no sentido mais imediato, de uma alusão à escuridão da noite, como indica Tournebroche ao informar um pouco antes que saía da rotisseria quando "il faisait nuit noire". Porém, o termo também traz à tona o local de Ange nessa estória. É ele quem ensina a Tournebroche as primeiras lições de leitura, porém o seu letramento não o torna um sábio como Coignard. O espaço privado de luz pode, nesse sentido, ser ampliado do sentido literal da noite escura para um sentido metafórico da situação de ignorância vivida pelo personagem, novamente em oposição ao herói intelecutal Coignard ${ }^{72}$.

Retomemos os detalhes da comparação na cena de Ange: um passo ao mesmo tempo hesitante e triunfal faz saltar das sandálias de Ange à água ali acumulada, os "magníficos fragmentos de lama". Nesse olhar detalhado da cena, uma espécie de close narrativo, um elemento minúsculo é enfatizado e a comparação se amplia a partir dessa imagem destacada. O elemento em foco é a água lamacenta produzida pelas sandálias de Ange e parece celebrar sua "glória imoral". Mais do que o personagem já rebaixado pelo narrador, o que está em foco é a lama levantada pelas suas sandálias, simbolicamente ainda mais aviltante. Já no outro lado da comparação, há um movimento inverso ao close narrativo, uma ampliação significante: da lama das sandálias de Ange, o narrador nos conduz às fontes de Versalhes de onde jorra a água dos chafarizes em homenagem aos reis. Do lado do comparado, o narrador brinca com a imagem de Ange ao escolher da sua figura a lama das sandálias e sua "glória imoral".

\footnotetext{
${ }^{71}$ Também segundo Schoentjes, há um componente moral que perpassa a constituição da ironia. Segundo ele, nas aproximações semânticas inesperadas, são as imperfeições do mundo que acabam reveladas.

${ }^{72}$ Outro personagem de France, Crainquebille, um vendedor de legumes, de conto homônimo, é também caracterizado pela incapacidade intelectual que o leva a um destino trágico.
} 
Enquanto isso, do lado do comparativo ${ }^{73}$, há uma ampliação da visão e o jogo se torna mais crítico.

Pelos dois elementos da comparação, essa água que sai das fontes da monarquia francesa está carregada da mesma lama que sai dos pés do personagem beberrão e devasso, alvo da ironia jocosa do narrador. No comparativo, a ironia se repete, porém num viés mais crítico. Trata-se de um fingimento narrativo no melhor estilo anatoliano, um paradoxo engenhoso que se realiza na inversão do sentido. A ironia está presente na falsa honraria aos reis. Quintiliano, segundo Schoentjes, discute essa fórmula de ironia, "le blâme par la louange" (a censura pelo elogio). Essa censura disfarçada impregna a ironia de uma valoração crítica, convertendo o ironista em "um moralista" (Schoentjes, 2001, p. 85). O narrador se torna moralista, pois há nele uma intenção de correção de um mundo imperfeito: o que era para ser representado como símbolo do poder e da perfeição, a glória das honrarias aos reis, é aproximado pelo narrador a uma situação banal: a lama que sai dos passos de um religioso de uma ordem inferior. E uma nova interpretação se forma: a glória dessas honrarias aos reis também é imoral.

O uso dos oximoros na construção da sentença auxilia muito no tom moralista da comparação. Henri Bergson, ao analisar o significado humano do riso em $1899^{74}$, fala da importância das oposições nos mecanismos da comicidade e nota que a oposição mais geral é a que mede "du réel à l'idéal, de ce qui est à ce qui devrait être" (Bergson, 2010, p. 97). Uma glória honrosa seria um elogio do narrador à representação da nobreza, porém, uma "gloire crapuleuse" inverte o sentido positivo. Se levarmos ainda em consideração que a comparação aproxima dois universos díspares, um capuchinho e os reis, outros elementos podem ser agregados à imaginação comparativa do narrador, um propriamente narrativo e outro temático.

Em primeiro lugar, há uma inversão do ponto de vista poético no nivelamento do mundo da realeza e do tipo religioso mais baixo: os reis de Versailles e a figura do beberrão. Em segundo lugar, essa associação remete a uma temática cara a Anatole France, qual seja: a relação promíscua entre a Monarquia e a Igreja. O que também se esconde sob a comparação é a posição autoral: o anticlericalismo de France. Apesar de

\footnotetext{
${ }^{73}$ Para Patrick Bacry, a imaginação comparativa de um escritor pode ser analisada com o exame das frases introduzidas pelo conectivo "comme". Essas comparações tornam "immédiatement sensible sa (do autor) vision personnelle du monde" (Bacry, 1992, p. 54). Par analisar essa "figure de ressemblance", Barrry divide na frase o elemento comparado ("comparé") e o elemento comparativo ("comparant").

${ }^{74}$ A primeira edição dessa obra de Bergson é de 1900. Consultamos a 13a edição crítica de 2010, sendo a $1^{\text {a }}$ de 1940.
} 
se passar no século XVIII, o romance das aventuras de Coignard está impregnado da visão crítica autoral em fins do século XIX. Ao associar a lama no sapato de Ange às fontes de Versailles, o narrador trata tangencialmente de um debate de forte repercussão na França de Anatole. Mesmo o romance de Coignard se passando no século XVIII, a separação entre Igreja e Estado que se efetivará somente em 1905 está na pauta de discussões no momento de publicação de La Rôtisserie, em 1893. O narrador insere, portanto, um debate contemporâneo ao autor no tempo do romance.

O que se pode concluir desta breve análise é que, de fato, a obra de France se dispõe a uma abertura interpretativa, provavelmente da qual a leitura de Barreto captou as nuances hermenêuticas. Além disso, na obra do escritor francês, não há como separar questões da narrativa das questões do contexto, elas se tangenciam recorrentemente. Autor atuante (pela palavra) nos debates de sua época, é no texto de intervenção L'Église et la République ${ }^{75}$, coletânea de artigos publicada em 1905, obra imprescindível para a compreensão da escrita de Anatole France, na qual a temática da separação entre Igreja e Estado pode ser lida com mais detalhes.

Esse conjunto de textos teve como ponto de partida o prefácio à coletânea dos discursos do chefe de governo entre 1902 e 1905, Émile Combes, Une campagne laïque, acrescido posteriormente dos discursos que o próprio France proferiu no período, assim como de um prefácio ao livro de Paul Grunebaum-Ballin, La Séparation des Églises et de l'État. Neles, France analisa as relações entre a Igreja e o Estado na França desde as eleições de 1871, quando o clima de medo pós-comuna deu aos conservadores as bases para a tentativa de restabelecimento da monarquia ${ }^{76}$. O que ele chama de Parti Noir, tradução política do poder religioso, adquire força nos acontecimentos do caso Dreyfus sob o disfarce nacionalista.

No texto, France analisa duas leis fundamentais no que diz respeito à história da separação entre Igreja e Estado na França: a lei Fallux ${ }^{77}$, de 1850, que deixava a cargo da Igreja os três níveis de ensino, e a lei Combes, de 1901, que determinava que nenhuma congregação religiosa de ensino poderia ser formada sem a autorização

${ }^{75}$ Este texto de Anatole France aparece citado na sátira Os Bruzundangas, como veremos na última parte do texto.

${ }^{76} \mathrm{Um}$ dos movimentos mais importantes do período foi o boulangismo, liderado pelo general Georges Boulanger. O movimento agrupou num mesmo bloco grupos nacionalistas de direita e descontentes de esquerda, ambos insatisfeitos com os rumos da República parlamentar, num contexto de crise econômica e de forte apelo nacionalista (com a perda da guerra para a Prússia em 1870).

77 "Cette loi livrait les trois degrés de l'enseignement à l'Église et coiffait la France du triregne de l'obscurantisme." (VTM2, 1953, p. 28). 
expressa do governo republicano. Essa coletânea de artigos também traz alguns elementos interessantes do ponto de vista temático e narrativo. Quanto ao tema, a história apresentada nos textos coincide em muitos momentos com os acontecimentos em M. Bergeret à Paris ${ }^{78}$ (MBP), de 1901. Do ponto de vista narrativo, aparecem nessa coletânea alguns procedimentos que serão repetidos na sátira L'Île des Pingouins, de 1908, como a divisão dos capítulos em partes de começo, meio e fím e a ironia do falso elogio, como vimos, já presente desde muito cedo na obra de France.

\section{Pequena e grande história}

Em Isaías Caminha, o narrador-personagem Isaías nos apresenta uma breve história de sua infância, ligada, a todo momento, às questões da inteligência. Logo nas primeiras palavras, o narrador ressalta "a desigualdade de nível mental” do seu seio familiar, o que teria lhe inspirado "anseios de inteligência". A desigualdade mental diz respeito ao contraste entre a ignorância da figura materna e o saber do pai. O saber idealizado do pai era para o menino Isaías, "um deslumbramento" (IC, 2010, p. 67), o que o fez nos primeiros anos de estudo, dedicar-se "açodadamente ao estudo", vislumbrando já no primário um futuro brilhante para si, era "como se o mundo me tivesse esperando para continuar a evoluir ..." (p. 68). Depois de terminados os estudos no Liceu, Isaías pensa em ir para o Rio de Janeiro, mas as dificuldades de sua nova empreitada são enunciadas pelo próprio narrador; lá "havia de ser como uma palha no redemoinho da vida" (p. 68).

Nestas primeiras linhas, o narrador esboça as suas primeiras impressões de infância num movimento de harmonia e divergência. Inicialmente, a desarmonia no interior do lar o direcionou para o deslumbramento com o mundo intelectual, com uma dedicação cega aos estudos. A suposta harmonia exterior do mundo que o esperava, porém, é rompida com a antecipação das dificuldades pelo próprio narrador-personagem que problematiza o futuro. Esse jogo de harmonia e divergências, ou esse embate entre o eu e o mundo no seio da obra aparece também extratextualmente no campo de batalha que se reproduz na história de publicação do romance. Em carta ao jornalista e escritor Gonzaga Duque, de janeiro de 1909, resposta a um artigo elogioso do autor de Mocidade Morta, Barreto explica que a escolha de Isaías Caminha como obra de estreia

\footnotetext{
${ }^{78}$ Os capítulos desse último volume da série Histoire Contemporaine saem, com exceção de um, em Le Figaro, de julho de 1899 a setembro de 1900. Em volume, a Calmann-Lévy lança a sua primeira edição em 1901. Consta no volume III da edição da Pléiade.
} 
em detrimento do romance de Gonzaga de Sá, também já pronto na época, tinha sido para "escandalizar e desagradar" com esse "livro desigual, propositalmente mal feito, brutal por vêzes".

Também os percalços da publicação e o silêncio da recepção de Isaías Caminha não fugiram à lógica do embate. Em fevereiro de 1909, Antônio Noronha Santos levou os originais do romance para o editor Antônio Maria Teixeira, em Lisboa, mas ele só chegaria às livrarias em dezembro, depois de muitas idas e vindas, correções e atrasos. A repercussão foi pífia. Segundo Barbosa (1959), poucas foram as notas sobre o romance nos jornais. Do Correio da Manhã, duramente atacado no romance com o nome de $O$ Globo, o silêncio foi total. À boca pequena, os rumores dos nomes reais que estavam por trás dos personagens fictícios deviam correr a cidade, sendo que a chave seria mais tarde revelada pelo próprio Noronha Santos. O primeiro crítico a falar sobre o romance foi José Medeiros e Albuquerque, em A notícia, de 15 de dezembro de 1909, em artigo assinado sob o pseudônimo de J. dos Santos. Apesar de elogiar o escritor, diz que a obra é "um mau romance e um mau panfleto"79. Alcides Maia ${ }^{80}$ considerou o livro um desabafo "mais próprio das secções livres que do prelo literário" (CAP1, 1956, p. 177). Também o crítico José Veríssimo, em carta de março de 1910, apesar de destacar o talento do escritor, não deixou de apontar o excessivo personalismo do romance.

O tom de confronto, que no romance aparece muito cedo no jogo de harmonia e divergência entre o eu e o mundo, já estava enunciado no prefácio, quando Isaías fala do motivo pelo qual começara a escrever suas recordações. O estímulo inicial viera da leitura de um artigo de "uma revista nacional", na qual um dos colaboradores criticava as pessoas do seu nascimento que, brilhantes na infância, fracassavam na idade adulta. Segundo Isaías, a sua reação imediata ao artigo foi de raiva. Aos poucos, porém, ele foi revendo a crítica e se acalmando. Enfim, ele reelabora a situação da seguinte maneira:

"Não sei bem o que cri; mas achei tão cerrado o cipoal, tão intrincada a trama contra a qual me fui debater, que a representação da minha personalidade na minha consciência, se fez outra, ou antes esfacelouse a que tinha construído. Fiquei como um grande paquete moderno cujos tubos da caldeira se houvessem rompido e deixado fugir o vapor que movia suas máquinas. “(IC, 2010, p. 64)

\footnotetext{
${ }^{79}$ Santos, J. dos. "Crônica Literária”, in A Notícia, Rio de Janeiro, 15 dez. 1909. Esse artigo foi consultado em Barreto (PS, 2006, p. 29-30).

${ }^{80}$ Segundo Barbosa, é a ele que se atribui a mudança da profissão do personagem principal do romance de garçom a contínuo e repórter. O artigo foi assinado com a inicial A. no Diário de Notícias, de 16 de dezembro de 1909.
} 
Novamente um embate, mas a posição de Isaías se transforma. A comparação entre o estado de Isaías e o paquete moderno com os tubos rompidos nos leva à interpretação de um eu avariado, que não funciona mais dentro do mundo moderno e se crê fora da sociedade. $\mathrm{Na}$ frase, o narrador antecipa a inviabilidade do projeto do personagem Isaías, fracasso que não é só dele, mas dos negros na vida adulta. A causa, por sua vez, não estaria na incapacidade individual, mas numa falha na sociedade. Nessa complexa relação entre o eu e o mundo, que continua no decorrer de todo o romance, é essa mesma sociedade moderna diante do paquete avariado que vai afundando os sonhos do menino Isaías.

Nesta relação entre o eu e o mundo, também a cidade do Rio de Janeiro nos parece parte do universo desencantado. De fato, o livro se passa na Primeira República, no período da Belle Époque carioca, nos tempos da reforma de modernização do prefeito Pereira Passos na cidade do Rio de Janeiro, modernização que desfigura a cidade, assim como a sociedade altera os traços essenciais de Isaías. Não estaria aí uma identificação do narrador com a cidade transformada? Não seria esse eu inadequado um espelho dessa cidade cuja história se perde como nas escavações do Morro do Castelo $^{81}$ ?

Nesse sentido, a situação existencial anulada pela sociedade teria um sentido ampliado. Como a passagem entre a lama dos sapatos de Ange e a crítica à monarquia clerical, em Lima Barreto, também, o elemento menor nunca se encerra nele mesmo. Há sempre uma associação possível com o contexto social ou, no caso, com a história de publicação da obra. Assim como a cidade vai sendo alterada nos seus traços essenciais, a criança que sonhava com o futuro grandioso vai sendo assimilada pela estrutura social que lhe é imposta. Os ideais de grandeza da criança brilhante vão, no decorrer do romance, dando vez a uma gradual apatia e assimilação, como a cidade que vai deixando para trás as marcas da história e se desfigurando. Ou os negros que vão sucumbindo diante das injustiças sociais.

Desta maneira, o que observamos nos dois autores é um paralelo que se repete entre duas camadas de histórias, a pequena e a grande história: o universo do romance, com seus personagens e tramas, e o universo da História. No caso de Isaías Caminha, a história da assimilação do eu corre paralelamente à reformulação da cidade, vista como

${ }^{81} \mathrm{Na}$ série de crônicas intitulada $O$ subterrâneo do Morro do Castelo, escritas para o Correio da Manhã, em 1905, Barreto trata das escavações que a prefeitura do Rio de Janeiro realizava nesse espaço onde seria erguida a Exposição do Centenário da Independência em 1922. Ver Barreto (1997). 
desintegração ${ }^{82}$. No caso de France, a ironia jocosa em relação a Ange corre paralelamente à critica subjacente da relação promíscua entre e monarquia e igreja. De uma forma ou de outra, o que se percebe nesses dois casos é a construção de um percurso crítico cujo mecanismo se desvenda na teia de relações construídas pelos narradores. As situações aparentemente mais corriqueiras já trazem em si uma relação com o contexto.

\section{Narradores-enganadores}

Uma figura aparece na obra de Barreto e na de France: a dos sibaritas, homens afeitos aos prazeres físicos, à voluptuosidade e à indolência. Eles aparecem num conto de Barreto, A Indústria da Caridade ${ }^{83}$ e no romance Les dieux ont soif ${ }^{84}$, de 1912 . No conto, dois sibaritas conversam em uma confeitaria sobre a vida dos outros e em Les dieux, o vocábulo caracteriza Brotteaux, o construtor de marionetes.

Em A Indústria da Caridade, o narrador descreve dois amigos que conversam numa confeitaria: "Eram sibaritas desses lugares. Gozam em contar um ao outro o que sabem da vida faustosa dessa gente que, rica de uma hora para outra, se empavesa de repente com coisas caras ...” (HS, 1956, p. 233). Eles conversam sobre os frequentadores da confeitaria e, depois de passarem a sala em revista, deparam-se com uma família "desconhecida" e o mais velho dos amigos, Chichorro, pergunta ao outro, o Veiga, se ele conhece "aquela gente". Veiga responde se tratar da família do Major Almério, um "homem honesto" que exercia legalmente a "indústria da Caridade". Veiga cita então o romance Renée Mauperin dos irmãos Goncourt, e reproduz a frase de um personagem da obra que afirma: "o furto é a maior indústria de nosso tempo" (p. 234).

Com esta frase tomada de empréstimo aos irmãos Goncourt, a indústria da caridade vai ganhando o verdadeiro sentido almejado pelo narrador. Este outro sentido se fortalece com a fala de Veiga sobre o tal major Almério que fizera fortuna "à custa de manifestações a tudo quanto é impopular, portanto, do agrado do poder" (p. 236). Aquele aspecto enganador de France que vimos no começo do capítulo nos parece ter sido absorvido pela pena limabarretiana. Novamente, numa sequência de frases que se

${ }^{82}$ Somam-se a esta ampliação a história da publicação e dos negros. Debruçaremo-nos mais sobre o paralelo entre o eu e a cidade em processo de transformação.

${ }^{83}$ Esse conto está na edição de 1956 de Histórias e Sonhos, mas não consta na edição de 2008, que recupera a versão originalmente selecionados pelo autor.

${ }^{84} \mathrm{O}$ romance saiu primeiramente na Revue de Paris em cinco partes, de novembro de 1911 a janeiro de 1912. A edição original é de junho de 1912, publicada pela Calmann-Lévy, tendo sido adaptada para o teatro por Pierre Chaîne, com a peça representada em 1923. Consta no volume IV da Pléiade. 
contradizem, o leitor de Barreto também vai se deparando com um narrador ludibriador. Também a resposta de Chichorro, "nem tudo o que é popular é justo" desfaz o que se espera do senso comum, invertendo o ideal como forma de denúncia do real. A associação da caridade à indústria e ao furto já vinha sugerindo essa inversão.

A figura do sibarita aparece no romance Les dieux ont soif, caracterizando Brotteaux, o fazedor de marionetes, no momento em que ele oferece abrigo ao perseguido padre Longuemare, que foge do regime do Terror: "Brotteaux, en son grenier, lui servit du pain, du fromage et du vin, qu'il avait mis à rafraîchir dans sa gouttière car il était sybarite.” (Les Dieux, 1994, p. 531-532). Brotteaux é, como Coignard, o personagem do sábio humanista, mas diferentemente do abade, é um provocador anticlerical. Ele é também um discípulo de Epicuro, um sensualista. Daí o termo "sybarite", com o qual o narrador define o personagem. Porém, a descrição da moradia de Brotteaux, que justifica a sua nomeação no texto, é oposta ao luxo e refinamento que caracterizam o sibarita.

A oposição, porém, não se encontra no termo, mas na própria frase enunciada pelo narrador. Em um texto publicado na revista The French Review, Marisol Amar (1970) trata de um procedimento em France que consiste em "utiliser un mot-outil pour un autre", cujo resultado é a modificação da "relation naturelle, grammaticale ou syntactique, entre deux termes ou deux propositions" (Amar, 1970, p. 885). Há, nessa operação, um deslocamento entre o sentido e a sua expressão:

... ce qui au niveau du sens des mots était associé est opposé dans le style par l'usage d'un mot-outil inattendu, ou ce qui était opposé par le sens se trouve associé sur un même plan, la cause prendra en apparence la place de l'effet, la condition devient conséquence et ce qui normalement précède dans la succession logique des événements a l'air soudain de suivre. (Amar,1970, p. 885).

Essa inversão do sentido pela utilização de um conectivo que não corresponde ao sentido esperado entre duas ideias é o que dá ao jogo de ironia do texto anatoliano uma forma discreta e sutil. O leitor, ao fazer a leitura da frase, acompanha o raciocínio apontado pelo conectivo, mas nessa situação de deslocamento, ao perceber a incoerência entre os termos, "la surprise provoquera ce sourire qui établit la complicité avec l'auteur" (p. 886). Amar observa esse deslocamento a partir de uma frase de La Rôtisserie na qual France modifica a relação lógica de causa e consequência. Logo na primeira página do romance, o narrador diz: "J'ai connu un cabbaliste gascon dont je ne puis dire qu'il était sage car il périt malheureusement, ...” (RRP, 1987, p.03). A relação 
lógica de causa e consequência que o narrador estabelece entre uma vida de sabedoria e uma morte trágica não é uma relação esperada, mas a contradição não salta aos olhos numa primeira leitura. Por isso, segundo Amar, “l'effet ironique passe presqu'inaperçu dans cet exemple" (Amar, 1970, p. 886). No caso da frase do sibarita, temos também uma oposição de causa e consequência. Entre a ação de colocar o queijo e o vinho para refrescar na calha de seu sótão e o estado de sibarita, não há uma relação explicativa. Assim como no exemplo citado por Amar, o uso do conectivo não corresponde ao sentido esperado entre as duas orações. Segundo Amar, este procedimento seria uma forma de amenizar a intensidade da crítica:

"La substituition d'un mot-outil par un autre fait ainsi admettre comme par surprise au lecteur confiant des opinions subversives contre lesquelles il réagirait, fussent-elles exposées sérieusement. Le procédé revient à dorer fort savamment la pilule." (Amar, 1970, p. 889).

Encontramos um procedimento semelhante no diálogo entre Veiga e Chichorro. Quando Veiga responde ao amigo sibarita sobre a manutenção dos privilégios do major Almério, explicando que isso se dá à custa de manifestações "a tudo quanto é impopular, portanto, do agrado do poder" (HS, 1956, p. 236), o conectivo portanto não estabelece uma conclusão lógica do raciocínio, mas é o próprio narrador que cria, a partir de um deslocamento de sentido, uma nova relação, associando o impopular àquilo que é do agrado do poder. O sentido obtido é que o poder aprecia não o que deveria apreciar, o bem estar e a satisfação daqueles que representa, mas sim o que não é do reconhecimento da maioria da população, o impopular. Partindo dessa ironia sutil do narrador que "doura a pílula" da crítica, também a percepção inicial dos sibaritas como fofoqueiros ou como partes do mundo social arrivista da confeitaria, é, ao final, invertida. Os sibaritas são os que mantêm um olhar crítico sobre o real, e, o sensualismo anatoliano - diretamente ligado a essa figura de vida nababesca e tão difundido aqui no Brasil - começa, no procedimento de inversão, ironia e crítica, a ganhar ares de engajamento. O que Lima Barreto incorpora da lógica enganadora do narrador anatoliano é essa ironia sutil e subversiva que "doura a pílula" sem deixar de aplicar o remédio ${ }^{85}$.

${ }^{85}$ Cabe ressaltar que o caso limabarretiano é bem menos sutil que o procedimento em France. Isso acontece em grande parte devido ao trabalho com a linguagem que em Barreto tem como fim se contrapor aos literatos. Ainda assim, a lógica de inversão do que é esperado pelo leitor segue a mesma chave anatoliana dos conectivos imprevistos. 


\section{Nota sobre Recordações do escrivão Isaías Caminha ${ }^{86}$}

“Afortunados, os tempos para os quais o céu estrelado é o mapa dos caminhos transitáveis e a serem transitados, e cujos rumos a luz das estrelas ilumina. "(Lukács)

Existe, para muitos críticos, uma divisão em duas partes no romance de estreia de Lima Barreto, sendo que a segunda parte, depois da entrada de Isaías no jornal, é, em geral, considerada como um desvio de rumo da obra. É o caso de Lucia Miguel Pereira que vê nesse desvio uma perda do sentido do romance: "O livro foi evidentemente desviado do seu rumo, não por má-fé, mas porque o autor como que perde o fio e o sentido do romance, que começa introspectivo e se transforma em panfleto caricatural." (Pereira, 1988, p. 291) Segundo Pereira, os indícios dessa mudança do tom instrospectivo ao caricatural residem na transformação do próprio Isaías, que vai ficando grosseiro e vaidoso, como demonstraria a insensibilidade do narradorpersonagem em relação à morte de sua mãe, tratada no romance brevemente e com pouca importância.

Certamente, há uma mudança no romance, mas os elementos dessa transformação estão dados desde o início do livro. Primeiramente, o ar combativo vai se radicalizando na medida em que a relação do eu com o mundo vai se ampliando e se associando ao destino da cidade, sucumbindo ao presente pragmático. Em segundo lugar, a transformação de Isaías não passa por uma ação, ele não se torna grosseiro e vaidoso. Pelo contrário, ele é assimilado pelo mundo do outro (jornal e política) e a vaidade do menino Isaías vai se esvaindo nas decepções do adulto. A "insensibilidade" em relação à mãe é mais um resultado de uma indolência, uma apatia frente ao cipoal do mundo do que resultado da vaidade do personagem que, com exceção do final, nunca se mostra orgulhoso. Mesmo porque o trecho em que o personagem fala da morte da mãe, apesar de curto, é sentimental e repleto de poesia, de forma nenhuma insensível. É uma tristeza de alguém habituado a uma vida de exclusão:

"Morria minha mãe! E via-a logo morta, muito magra, os círios, o crucifixo, o choro... Passou-me pelos olhos a sua triste vida, humilde e humilhada, sempre atirada a um canto como um móvel velho, sem alegria, sem fortuna, sem amizade e sem amor ..." (IC, 2010, p. 167168).

\footnotetext{
${ }^{86}$ Essa digressão sobre o romance de estreia de Lima Barreto, apesar de destacada do caminho de construção da tese, faz-se relevante na medida em que enuncia uma compreensão da obra fundamental tanto da perspectiva comparativa como do ponto de vista teórico.
} 
Tal como a causa do fracasso do menino Isaías estava "na sociedade e não no indivíduo desprovido de tudo", também sua mãe foi outra vítima da vida humilhada reservada aos injustiçados. Enquanto Isaías escolhe o caminho da integração ao mundo, deixando para traz seus projetos de criança, a mãe sucumbe como um "móvel velho". Isaías, que no início do romance sentia-se como um "paquete moderno" avariado, deixase absorver pela ordem corrompida da "fábrica de carapetões" do jornal e, na sequência, pela política. Acompanhando o mesmo processo de insulamento ${ }^{87}$ dos personagens do romance, consideramos que a mudança de tom da primeira para a segunda parte do romance, cujo ponto de ruptura se dá com a entrada de Isaías para o jornal $O$ Globo, é um dado constitutivo da obra, não um aspecto depreciativo do romance.

E essa transformação não é abrupta, mas sim gradual. A modificação gradativa deixa rastros na narrativa, como, por exemplo, na repetição de alguns campos semânticos usados em comparações no decorrer do romance, como o das embarcações (o avariado paquete moderno). No final do capítulo III, Isaías caminha pelas ruas refletindo sobre a figura do romeno Gregoróvitch: "Subia a rua. Evitando os grupos parados no centro e nas calçadas, eu ia caminhando como quem navegava entre escolhos, recolhendo frases soltas, ditos, pilhérias e grossos palavrões também" (IC, 2010, p. 103). A sensação de andar nas ruas da cidade é análoga ao movimento de embarcações nas águas. Diferentemente da comparação anterior, na qual a imobilidade estava associada a uma embarcação moderna, mas avariada, a nova situação do personagem transforma a estagnação em movimento, em navegação. E esse navegar se dá entre o mundo das pessoas, do qual ele recolhe frases, ditos, pilhérias. Isaías participa do mundo evitando a imobilidade, "os grupos parados no centro", porém ele está mais sendo levado do que guiando o próprio caminho. Há um movimento da estagnação do paquete que se transforma em deslocamento nesse trecho, mas o navegar não coloca o personagem em movimento autônomo, mas inercial.

O navegar no mundo não se converte na transformação tão aguardada pelo menino Isaías, o sonho de ser doutor no Rio de Janeiro. As dificuldades desse mulato na cidade: a prisão, a fome, o desemprego, vão aniquilando a sua individualidade. A divisão que muitos veem no romance entre uma escrita intimista e uma caricatural nada mais é do que o processo de eliminação da individualidade, de aniquilação do eu. E esse

${ }^{87}$ Osman Lins, no belo livro que escreve sobre Lima Barreto, defende que as figuras dos romances de Barreto sofrem de uma espécie de insulamento, uma "inoperância dos atos de cada personagem sobre o próximo e sobre o meio" (Lins, 1976, p. 37). 
eu acovardado, essa individualidade adormecida, desponta na comparação que aparece logo no início do sétimo capítulo do romance, no qual o narrador fala da fase mais difícil de sua vida, pouco antes de sua entrada no jornal: "A minha individualidade não reagia; portava-se em presença do querer dos outros como um corpo neutro; adormecera, encolhera-se timidamente acobardada." (IC, 2010, p. 149). É esse indivíduo neutralizado, assoberbado que dá lugar ao satirista. Como se ao corpo neutro e adormecido o narrador sobrepusesse o crítico. Este processo já havia aparecido nas primeiras caricaturas do terceiro capítulo, mas é somente no quinto capítulo que Isaías incorpora o viés crítico do jornalista romeno, dr. Ivã Gregoróvitch Rostóloff ${ }^{88}$. Foi ele quem conseguiu o emprego para Isaías, como também foi quem anteriormente forneceu o álibi para que o ingênuo mulato não fosse preso sob a acusação de roubo na pensão em que viveu no início do romance.

Gregoróvitch é uma espécie de iniciador crítico do ingênuo Isaías. É o ponto de intersecção entre a história individual da deformação e a história crítica da formação do narrador militante. Um primeiro indício da relevância desse personagem está na posição que ele ocupa na lógica de organização do jornal, no lado oposto dos "arautos da palavra literária", o crítico Floc, Frederico Lourenço do Couto, e o consultor gramatical Lobo $^{89}$. Enquanto Lobo e Floc eram os "dois mais altos ápices da intelectualidade de $O$ Globo" (p. 182), que não se metiam nas polêmicas, Gregoróvitch era a "artilharia". Outro indício do seu diferencial é o tratamento não caricatural que o narrador dá a ele, revelando-nos inclusive que ele se "sentia", esse "sem pátria", liberto das "tiranias morais e psicológicas que essa noção contém em si” (p.124). Também, assim como no caso de Coignard, o narrador dá voz ao personagem. Conhecemos Gregoróvitch a partir das perguntas feitas por Isaías, às quais o romeno responde contando um pouco de sua experiência pregressa. Mais à frente, o próprio narrador revela ao leitor a origem do personagem depois de um "almoço de camaradas, rico de confidências". Gregoróvitch era da România, seu pai era um emigrado russo e sua mãe era grega; ele "estudara no Cairo e acabara o seu curso em Sofia, correra a Europa, a Ásia e América”.

O primeiro contato de Isaías com o romeno causa naquele um "grande estupor",

88 Segundo nota da edição consultada, trata-se do jornalista italiano e anarquista, Mário Cattaruzza que, no Correio da Manhã, auxiliou um jornalista com as características de Caminha, José Vieira.

${ }^{89}$ Segundo nota da edição de 2010, Floc representa o paranaense João Itiberê da Cunha, um dos fundadores do Correio da Manhã e Lobo, Cândido Lago, que assinava no mesmo jornal a seção "O que é correto". 
pois Gregoróvitch o estimulara a "corrigir a doçura nativa de todos nós", e pela primeira vez Isaías ouvia alguém dizer mal da piedade e da caridade, como "sentimentos antissociais, enfraquecedores dos indivíduos e das nações ...”. É o romeno, inclusive, que faz "uma formidável charge aos nossos intelectuais", no modelo que o narrador já ensaia no início do romance e que radicalizará na segunda metade do livro: "Referindose ao Lage ${ }^{90}$, chamou-o de águia, homem de presa, super-homem ...” (IC, 2010, p. 125126).

Se, de um lado, Gregoróvitch perde a importância depois da entrada de Caminha no jornal, de outro, é dele o viés crítico incorporado pelo narrador que não pode reproduzir as palavras do jornalista simplesmente porque elas se tornaram suas próprias palavras. É interessante ainda pensar na relação entre Isaías e Gregoróvitch como símbolo de um diálogo nacional-estrangeiro. Neste sentido, a importância do romeno sugere uma espécie de consciência que coloca o nacional em perspectiva. Sem estar assimilado pelo jogo de poderes no país, ele consegue imprimir um viés bastante crítico em suas opiniões e artigos. E é um dos únicos que busca outras paragens ao final do romance. Enquanto a grande maioria dos funcionários busca os favores dos poderosos na distribuição de cargos públicos e outros enlouquecem ou se suicidam, Gregoróvitch segue rumo a Caracas, "desgostoso com a cor governista do jornal” (p.295).

Se Gregoróvitch não tem um tratamento caricatural na narrativa, o mesmo não se pode dizer dos outros funcionários do jornal $O$ Globo que, diferentemente do romeno e como Ange -, não tem voz no romance. Esse processo de caricaturização ${ }^{91}$, de interferência crescente do satirista na narrativa, está presente já no terceiro capítulo, bem no início do romance. Aparece ali o "Pithecanthropus literato", o "espantoso" Raul Gusmão", "uma desencontrada mistura de porco e de símio adiantado" (p. 88). A artificialidade da linguagem de Gusmão assombra o narrador: "Toda a sua pessoa se movia, se esforçava extraordinariamente; todos os seus músculos entravam em ação; toda a energia da sua vida se aplicava em articular os sons ...” (IC, 2010, p. 87). Diante

90 Lage da Silva é Paschoal Segreto, segundo nota, uma figura popular no Rio de Janeiro do começo do século XX, tendo sido o primeiro grande empresário do ramo do entretenimento no Brasil. É o primeiro personagem com quem Barreto trava conhecimento ao chegar à capital.

91 Para Vladímir Propp (1992), a caricatura é uma das três formas do exagero cômico, juntamente com a hipérbole e o grotesco. Na caricatura, a representação cômica reside em tomar uma particularidade qualquer da pessoa e representá-la como única, exagerando-a. Na hipérbole, o exagero seria do todo, enquanto o grotesco seria o grau mais extremo do exagero, possível apenas na arte, mas não na vida.

${ }^{92}$ Raul Gusmão é o escritor João do Rio. 
desse "grande literato", dessa espécie de "Balzac ou Dickens", Isaías se cala "respeitosamente", mas ao final do parágrafo, completa que ficara esmagado pela figura de Gusmão, "apesar dos seus guinchos de Pithecamthropus", gênero da espécie Homo erectus. Gusmão é um humano de outro gênero, que lembra "vagamente uma raça qualquer de suíno", uma mescla de "suíno e de símio".

A denúncia do falso, da artificialidade, é o que explica a necessidade do caricatural em Barreto, segundo Antonio Arnoni Prado (1976; 1989). Para o crítico, o nível caricatural é resultado da visão da retórica como falso, o que leva o escritor em início de carreira a eleger o nível da caricatura para efetuar o "abalo da mimese". Esse nível caricatural está nas inúmeras descrições de vários personagens do romance, na verdade mais tipos ${ }^{93}$ do que personagens: o jornalista é "como o pirata antigo", Aires d'Ávila" possui uma "imensa cabeça de porco", o "macio Frederico Lourenco do Couto", o Floc, tinha o queixo como um "aríete de couraçado" - novamente aqui recorrendo ao campo semântico naval. Temos ainda o doutor Ricardo Loberant ${ }^{95}$, diretor do jornal, admirado como "um deus" e que pairava no jornal como um "sátrapa", um déspota.

Todos fazem parte da mesma trajetória narrativa do personagem sonhador, dominado e neutralizado pelo contato com o mundo, que se deixa levar pela voz do satírico Gregoróvitch e cuja mudança de posição vai se formando gradativamente: da interioridade mascarada na relação entre o eu e o mundo ao distanciamento narrativo na relação com o outro ${ }^{96}$, caricaturizado. Somente Gregoróvitch escapa à tipificação, pois esse personagem é incorporado pelo narrador, como o olhar de fora, autônomo, estrangeiro. É esse olhar "de fora" que fornece a chave para se entender o que se passa

${ }^{93}$ Sobre a relação entre personagem e realidade no romance, Antonio Candido (2009) propõe uma concepção gradativa, mais sutil e menos reflexiva em relação ao real, na qual a criação da personagem passa por um processo de convencionalização, um trabalho de seleção de traços pelo narrador "... dada a impossibilidade de descrever a totalidade duma existência" (Candido, 2009, p. 75). A verdade da personagem, com o conceito de convencionalização passa a ser mais um problema de organização interna do que de equivalência à realidade exterior. Nesta concepção, o personagem é uma espécie de vetor resultante de uma gama de traços dentro de uma lógica particular criada pelo autor e posta em prática pelo narrador. Nesta gradação, os personagens de Barreto se aproximariam mais dos personagens planos, construídos em torno de uma única ideia ou qualidade, também chamados de tipos ou caricaturas.

${ }^{94} \mathrm{O}$ nome do personagem no romance é Pacheco Rabelo, redator-chefe do jornal. Trata-se do alagoano Pedro Leão Veloso Filho, o Gil Vidal, redator-chefe do Correio da Manhã , jornal que ajudou a fundar.

95 Trata-se de Edmundo Bittencourt, polêmico proprietário do Correio da Manhã.

${ }^{96} \mathrm{O}$ processo de insulamento de Lins nos parece então caminhar no sentido de um engajamento. 
no Brasil, pois para aqueles que aqui nasceram a adesão a uma violência naturalizada parece inevitável (ou o total aniquilamento).

Em artigo recente sobre o romance Isaías Caminha, Irenísia Torres de Oliveira (2010) acompanha a perspectiva de Lúcia Miguel Pereira ao ler na obra de estreia de Lima Barreto um descompasso entre a primeira e a segunda parte do romance. Oliveira parte de dois pressupostos teóricos. Primeiramente, transpõe a interpretação de Roberto Schwarz (2000) para a análise de Isaías Caminha. No estudo sobre Machado de Assis, Schwarz ressalta o descompasso entre realidade brasileira e convenção literária europeia nos romances machadianos, processo já enunciado por Schwarz em José de Alencar, em cuja obra observou "desacordos objetivos" na transposição dos modelos europeus. A segunda referência para a análise de Oliveira está em Carlos Nelson Coutinho (1974), que segue a perspectiva de Georg Lukács, e vê o mesmo problema no romance de estreia de Barreto, uma obra desigual, na qual a segunda parte estaria entregue "à mera descrição", perdendo assim a "totalidade abrangente da vida" (Oliveira, 2010, p. 82).

A interpretação de Oliveira incorre, ao nosso ver, em dois desacertos. De um lado, atém-se a um modelo europeu reduzido, de outro, compreende a sátira com gênero e não como "método criativo". Vejamos primeiramente a relação com os modelos. A ruptura no romance ocorre com a entrada de Isaías para o jornal como contínuo. Segundo Oliveira, Isaías entra então em uma nova fase, na qual "o enredo retrocede para dar lugar à sátira" (p. 91). E o motivo dessa alteração de registro ou de gênero teria ocorrido em função dos modelos europeus aos quais Barreto estaria atrelado:

"Essa alteração ocorre justamente porque Lima Barreto tem em vista, de maneira muito consequente, um modelo pregnante de romance (Dostoiévski, Balzac, Stendhal, Flaubert), com o qual tenta contar a história de um jovem mulato brasileiro, do início do século XX.

Esses modelos que se impõem ao espírito de Barreto: Dostoiévski, Balzac, Stendhal, Flaubert, certamente figuravam no rol de leituras do autor, inclusive constando todos eles na Limana. Porém, o foco nesses autores consagrados ainda nos dias de hoje, acaba deixando de lado alguns nomes esquecidos, mas que tiveram forte influência naquele período. Também não considera a forte influência dos seus pares dentro do país, como o próprio Gonzaga Duque, ou os anarquistas Fábio Luz e Curvelo de Mendonça, dentre muitos outros olvidados pelos estudos literários locais. Sem falar em autores como Afrânio Peixoto e Coelho Neto, presentes ainda em algumas publicações atuais, mas pouco lembrados no estudo das influências literárias da Belle 
Époque carioca. Se pensarmos na coletânea de artigos que compõe as Impressões de Leitura, veremos, de um lado, a filiação a Anatole France, na literatura militante apregoada por Barreto, e de outro, o interesse do autor na obra de seus contemporâneos $^{97}$. Todos esses diálogos nos parecem deixados de lado na compreensão de Oliveira.

Quanto à literatura militante, já aludida anteriormente, mais do que a declaração explícita de filiação: "A começar por Anatole France, a grande literatura tem sido militante", Barreto, que se julga um aprendiz dessa grande arte, utiliza-se, como vimos propondo, de procedimentos que se ligam aos de Anatole France. Portanto, o desacerto entre o modelo europeu e a realidade nacional não pode ser pensado somente em função dos autores consagrados da nossa matriz literária europeia. É preciso considerar os nomes e as influências de autores pouco lidos hoje, mas extremamente relevantes à época.

Outro elemento fundamental aproxima os narradores (e os autores) de France e Barreto: reside na figura do herói intelectual, esse personagem inseguro e consciente de suas limitações, que aparece numa vasta gama de romances, tanto na França, como também no Brasil. A elasticidade do gênero romance e as suas respectivas configurações históricas nos colocam diante de um quadro complexo e multirreferencial, do qual só dispomos de algumas pistas que refazem elos de afinidade e filiações, muitas vezes frágeis e circunstanciais. Por isso mesmo, ater-se a alguns "modelos pregnantes de romance", sem o exame mais minucioso dessas filiações, pode resultar numa generalização arriscada.

Em relação à concepção de sátira, Oliveira recupera o jovem Georg Lukács da Teoria do Romance, de 1914-1915 ${ }^{98}$. O romance, sob a perspectiva lukácsiana, deveria construir um mundo temporariamente unitário que não deixa de revelar, por meio da ironia, o "alheamento e a hostilidade dos mundos interior e exterior". A ironia seria para o jovem Lúkacs a "autocorreção da fragmentariedade", enquanto a sátira recairia numa forma subjetiva de "superioridade fria e abstrata". Em nota, o prefaciador da edição de 2000 da Teoria do Romance, José Marcus Mariani de Macedo, indica que nos escritos

\footnotetext{
${ }^{97}$ Barreto trata de diversos autores hoje desconhecidos, como Gastão Cruls (Coivara), Enéias Ferraz (História de João Crispim), Mário Sete (Senhora do Engenho), Albertina Berta (Exaltação), Veiga Miranda (Mau Olhado), Orris Soares (A Cisma), João Lúcio, (Pontes \& Cia), dentre outros mais ou menos literários ou sociológicos, e até mesmo alguns mais conhecidos como Hilário Tácito (Mme Pommery) ou Monteiro Lobato (Urupês). Ver Impressões de Leitura (IL,1956).

${ }^{98}$ Esta nos parece ter sido a fonte principal de Carlos Nelson Coutinho.
} 
de juventude de Lukács, realmente pesa um tom pejorativo à sátira, definida como uma “ironia vazia de sua necessária objetividade". Porém, em 1932, Lukács retoma a discussão no texto "A questão da sátira", publicado pela primeira vez na Internationale Literatur, de Moscou. Nele, o teórico húngaro examina o que chama de "base do método criador" na sátira. Segundo Lukács, na sátira:

"É como se o escritor satírico [...] não tivesse de fazer mais do que retirar os tetos das casas a fim de nos mostrar, sob uma forma satírica acabada, a realidade tal como se oferece imediatamente aos nossos olhos e ouvidos." (Lukács, 2009, p. 173).

Diferentemente da profundidade formal da ironia, na sátira, a profundidade estaria no conteúdo, ela torna "necessário" o que aparece "por acaso" na realidade. O que se manifesta na sátira é uma impressão da realidade, qualitativamente diferente da realidade refletida, e a sensação do "grotesco e do fantástico" é criada na "contínua oscilação entre o real e o "irreal'”. Lukács recupera nesse texto a tradição alemã de Hegel e Vischer - que percebeu o gênero como incompatível com a época revolucionária - para propor a sátira não como gênero, mas como "método criativo", cujo domínio se estenderia da "polêmica e do poema de agitação ao grande romance e à grande comédia" e teria como pressuposto ideológico "o ódio e a indignação em face de um estado social justamente condenado à morte" (Lukács, 2009, p. 183).

Ainda que aponte para o "recuo do herói" na sátira - o que acontece mesmo na sátira como método criativo - Oliveira segue na compreensão da negatividade do gênero satírico como acreditava o jovem Lukács. Essa negatividade, como já vimos, tem a ver com uma abstração em relação ao romance, a mesma que Lukács critica depois em relação à fillosofia clássica alemã, particularmente em Schiller. Essa outra compreensão da sátira nos permite pensar novamente no caso de Isaías Caminha, na medida em que o domínio desse método criativo alcança o romance e tem como pressuposto ideológico o ódio e a indignação diante de um estado social decrépito. A observação das estruturas de poder e do jornal oferece a base para o exercício do satirista que se imiscui na estrutura romanesca. Pensamos que esse procedimento encontrado em Isaías Caminha se reverbera em boa parte da obra de Lima Barreto. E este procedimento encontra-se, certamente, referenciado nos textos anatolianos.

O curioso na argumentação de Oliveira é que ao final do texto ela chega à conclusão de que dada a fragilidade do herói Isaías, que é “jogado sem salvaguardas nas várias peripécias da loteria do favor", seria impossível, “construir uma experiência de 
si”. Apesar de apontar para a autoconsciência da fraqueza de Isaías, uma das características do nosso herói intelectual, Oliveira insiste no aspecto desigual do romance, ainda que ressaltando a sua beleza:

"A beleza desse romance desigual está na força de retirar algo para si, apesar de tudo, quer dizer, do meio de todas as inadequações, fazer cintilar uma questão relevante para o próprio destino." (Oliveira, 2010, p. 99).

Qual seria então essa questão relevante? Em nota, Oliveira aponta que o romance deixa em aberto "se o autorreconhecimento individual de Isaías terá alguma consequência", visto que nas décadas seguintes à publicação do livro ocorreriam fortes mudanças de orientação intelectual: o "desrecalque localista" da década de 1920, e o "sopro de radicalismo" dos romances de 1930, uma crescente "ida ao povo", termos que Oliveira recupera de alguns textos de Candido sobre a década de 1930, para apontar a relevância da questão racial no contexto dos estudos do romance. A questão relevante, portanto, estaria ligada ao destino do negro na literatura, antecipando debates futuros.

Nessa chave, o que a segunda parte do romance aponta - a responsável pelo seu caráter desigual - é para uma impossibilidade de mudança de destino face a um mundo social que não soube incorporar o negro recém-liberto. E as esperanças de mudança dessa situação não se apresentam num futuro próximo. Já citamos a frase final do narrador de Isaías: “Antes de entrar, olhei ainda o céu muito negro muito estrelado, esquecido de que a nossa humanidade já não sabe ler nos astros os destinos e os acontecimentos." (Barreto, 2010: 99). A frase, como bem observou Oliveira, assemelhase à primeira oração de Teoria do Romance, citada como epígrafe. É a esse outro mundo ideal de que fala Lukács que o narrador contrapõe o seu olhar, pois dentro do seu universo não há salvação possível. Somente o satirista seria capaz, nesse contexto, de oferecer uma retórica dessa impossibilidade. 


\section{O Jornalístico}

As questões da vida política e social ganham ainda mais relevância para Anatole France com o fim de sua colaboração como o Le Temps, em abril de 1893, e sua entrada no $L$ 'Écho de Paris ${ }^{99}$, no mesmo momento em que começa a publicar Les Opinions. Se na coluna literária era difícil ampliar a temática de suas crônicas, no novo periódico, a sua única obrigação era de "ne pas ennuyer le lecteur" (Bancquart, 1984, p. 1115). É também com Les Opinions que o escritor introduz com mais frequência os acontecimentos contemporâneos na ficção. O escândalo do Panamá teria dado, segundo Bancquart, uma primeira impulsão para que France expusesse suas opiniões por meio do seu porte-parole Coignard.

O romance das opiniões do religioso é uma coletânea dos ensinamentos de Coignard relatados por seu discípulo Tournebroche. Salvo em alguns momentos, como nos diálogos ou na interferência direta do narrador, como quando ele retira Coignard da livraria, "je tirais mon bon maître par la manche”, a grande parte da história é contada por um narrador que se divide em dois. De um lado, temos Tournebroche que, como em La Rôtisserie, dá voz a Coignard aproximando-o do leitor e tornando carismática a figura do padre beberrão. De outro, temos um narrador-crítico que interpreta a história. Esta duplicidade ao narrar nos remete ao caso de Isaías Caminha, na incorporação da visão crítica de Gregoróvitch. Esse duplo-narrador é uma das formas escolhida por esses autores para tratar, ao mesmo tempo, dos acontecimentos políticos e sociais de seus tempos, e da trajetória de um personagem no seu embate particular com o mundo.

A utilização do tempo na obra acompanha essa duplicidade dos narradores. Em Les Opinions, o primeiro tema político diz respeito aos Ministros de Estado. Em conversa com o senhor Roman na livraria à l'Image Saint Catherine, do livreiro Blaizot, o palco de algumas aventuras de Coignard e Ange em La Rôtisserie, a discussão recai sobre os homens de Estado. Diz o cético Coignard que “... depuis cinquante ans que j'existe, j'ai observé que ce pays avait plusieurs fois changé de gouvernement sans que

\footnotetext{
${ }^{99}$ Fundada em 1884 e dirigida desde 1890 por Valentin Simond, contava com colaborações as mais diversas, tendo inclusive Octave Mirbeau publicado aí uma "autobiographie à tendance anarchisante" (Bancquart, 1987, p. 1114). As colunas de France apareciam normalmente na parte ocupada pelo editorial, o que atesta a importância de seus artigos no periódico. Os textos publicados no L'Écho de Paris, assim como os do Le Figaro, estão disponibilizados no site http://gallica.bnf.fr/?lang=PT.
} 
la condition des personnes y eût changé” (OJC, 1987, p. 224). O escritor Roman, indignado, pergunta a Coignard como ele poderia falar assim no dia posterior à morte de um ministro de Estado. A reprimenda de Roman faz referência à morte de Jules Ferry, ministro da Educação, em 17 de março de 1893, sendo o capítulo publicado cinco dias depois no L'Écho de Paris. Nesse diálogo, o que se passa é uma sobreposição temporal, na qual o romance, cujos acontecimentos remontam ao século XVIII, narra acontecimentos que se passam um século depois. Essa sobreposição de dois tempos na narrativa ${ }^{100}$, a ambientação do século XVIII e as referências políticas ao século XIX, perpassará grande parte do livro, como no caso do diálogo acerca do canal do Panamá.

Outro ponto importante é a estrutura dialógica do livro. Diferentemente do romance anterior que narra as aventuras do padre, nesse volume, a ação é substituída, na maior parte do tempo, pelos diálogos. Quase sempre na livraria do sr. Blaizot, os debates de Coignard com outros frequentadores da loja ocupam o centro da narrativa. Em Les Opinions, todo o processo da caricaturização dos personagens sem voz parece mais dissolvida, transferindo a importância do personagem para a cena narrada ou para os diálogos. A atualidade transposta para o romance parece diluir um pouco a caricaturização, sem contudo anulá-la, ressaltando, assim, a relevância do jornalístico na escrita ficcional.

A relevância da atualidade no romance é expressa logo nas primeiras páginas da obra quando Coignard folheia um livro do dramaturgo e poeta Jean Racine e elogia uma de suas tragédias, onde Racine mostrara "qu'il entendait assez bien la politique" (p. 223). Com esse elogio, o narrador dá a entender que pode proceder de forma semelhante a esse dramaturgo, cujas tragédias tratavam da vida política de sua época. Aludindo à tragédia Athalie (Atália), de 1691, Coignard diz que nela Racine descobrira "quelquesuns des ressorts dont le jeu élève et renverse les empires". Esse é um ponto relevante, pois o narrador se refere a uma atribuição jornalística de fiscalização do poder. Mais do que isso, ele trata de uma forma jornalística e literária pela qual Racine teria edificado e destruído impérios. Esse modelo de escrita literária que se liga ao jornalístico, de

\footnotetext{
100 Tomamos de empréstimo aqui a concepção de Roland Barthes (2004) acerca da organização do discurso histórico. No texto "O discurco da história", Barthes se apropria dos shifters (signos) de Jakobson para tratar da passagem entre o enunciado e a enunciação. São três os shifters apropriados por Barthes: testimonial, discursivo e dos protagonistas. Quanto ao discursivo ou organizador do discurso, que nos interessa particularmente aqui, o crítico ressalta um problema relevante para o analista, “... que nasce da coexistência, ou melhor, do atrito de dois tempos - o tempo da enunciação e o tempo da matéria enunciada". (Barthes, 2004, p. 166), o mesmo que se coloca na história de Coignard.
} 
utilização de meios lúdicos para fins políticos, está na base da escrita anatoliana a partir de Les Opinions.

A centralidade da palavra não é algo novo na escrita anatoliana. Mas, o que vemos em Les Opinions se diferencia do que observamos até então: a junção da escrita jornalística, cotidiana, de denúncia do poder e um jogo lúdico e ficcional que torna a crítica mais suave, mas não menos implacável. Nesse jogo entre o jornalístico e o ficcional, os homens políticos aparecem como peças de um teatro de marionetes montado pelo narrador. Bancquart, ao tratar de Le Livre, sugere que France pratica em suas obras o que ela chama de "pacte du collectionneur", uma redução do mundo a dimensões mensuráveis. Nos quadros de diálogo criados pelo narrador, aqueles personagens antes caricaturizados aparecem agora como peças num teatro políticoliterário. Por isso, a alusão a Racine nos parece tão relevante.

A posição do narrador, porém, nem sempre consegue se manter sem contradições em relação aos homens de Estado. Quando Coignard conversa com o radical Jean Hibou, de um lado, ele segue o ceticismo de outros personagens anatolianos e diz que sendo os homens igualmente medíocres, não haveria diferença entre tipos de governo ou governantes. Por isso, ele diz preferir as coisas como estão, sem revoluções. Neste caso, as discussões políticas seriam apenas um jogo de palavras. Já quando fala com o sr. Roman, escritor tradicionalista, e com o secretário de um ministro de Estado, o sr. Gentil, Coignard afirma o contrário, que os novos governantes não poderiam ser piores que os antigos. A contradição no pensamento de Coignard é percebida por Tournebroche, com o que Coignard concorda e afirma: “... je viens de me laisser emporter par le coeur et de céder à la passion, comme le vulgaire" (OJC, 1987, p. 243). A posição de Coignard também depende do seu interlocutor: diante do radical,a permanência, diante do tradicional, a violência.

Coignard discute nos capítulos III e IV com Hibou e Roman respectivamente. Com Hibou, o religioso afirma que se tivesse que escrever algo sobre os "affaires du temps", ele faria uma sátira: “Je ferais de ce libelle des manuscrits qu'on passerait sous le manteau ...” (p. 235). Tratando dos ministros, ele seguiria na mesma linha: “... si jamais j'écris contre ceux-là, ce sera pour les flatter curieusemente dans leur vice et dans leur infamie.” (p. 236). Novamente, o falso elogio é o procedimento escolhido pelo personagem para a crítica aos poderosos. Mas, qual seria a razão da escolha da sátira como gênero apropriado para falar da política e dos políticos do seu tempo? Diz 
Coignard que a forma satírica seria mais "légère et plaisante", e acrescenta que seria mais conveniente que "la matière que la roideur morose d'un Tacite ou que la gravité patiente d'un de Thou" (OJC, 1987, p. 235). Para a descrição do homem de Estado, o religioso pensa num gênero leve e agradável, em oposição a rigidez do romano Tácito ou de um Thou ${ }^{101}$.

Porém, esse desejo satírico de Coignard desaparece assim que o "célebre libelista" Hibou o convida para ir com ele à Holanda, de onde escreveria virulentos libelos que poderiam vir a derrubar impérios. Hibou anseia por "détruire un de ces ministres qui m’ont lâchement enfermé à la Bastille!” (p. 236). Diante de tamanho ódio e virulência, Coignard recua e diz que não busca mudar o estado, mas sim seguir o exemplo da "vieille de Syracuse" que, observando que a um mau tirano sucedia um ainda pior, preferira manter as coisas como estavam. Ao ouvir essas palavras de Coignard, Hibou se encoleriza e acaba deixando a livraria ofendido com a recusa do religioso.

No capítulo seguinte, intitulado Affaire du Missisipi, Coignard discute com Roman e Gentil sobre um caso no qual foram envolvidos vários homens públicos. Segundo Bancquart, trata-se do escândalo do Panamá disfarçado do caso da falência da companhia das Indías, processo que se deu na primeira metade do século XVIII, novamente unindo dois tempos históricos na narrativa. Anatole France foi o único entre seus pares a insistir no escândalo Panamá no L'Écho de Paris. Vejamos brevemente os antecedentes do escândalo do Panamá.

Depois do fracasso de Boulanger e com as leis anticlericais de Jules Ferry, os monarquistas e a sociedade cristã têm que se adaptar à República. Em 1878, o papa Leão XIII sucede Pio IX e passa a defender uma mudança de comportamento da Igreja frente ao regime político. A encíclica Rerum novarum, de 15 de maio de 1891, busca modernizar o pensamento social da Igreja chamando os católicos a se desligarem do conservadorismo e a reformarem a sociedade no sentido cristão, trabalhando em prol dos trabalhadores ${ }^{102}$. Uma das orientações da encíclica era desvincular o catolicismo da monarquia. O papa chamava os católicos ao combate "au sein même de la République". Essa via, que ficou conhecida como ralliement, foi introduzida pelo cardeal Lavigerie,

${ }^{101}$ Segundo Bancquart, Jacques-Auguste de Thou, magistrado do século XVI, um dos redatores do Édito de Nantes, foi um "modèle d'efforts vers l'exactitude et l'impartialité, mais aussi un pastiche de Tite-Live assez pesant à lire." (Bancquart, 1987, p. 1152).

${ }^{102}$ Essas informações estão em Démier (2000). 
que convidou os católicos franceses a se aproximarem da República. Essa adesão, do ponto de vista político, não trouxe mais católicos para a assembleia legislativa eleita em 1893, mas acabou elegendo uma maioria republicana mais conservadora ${ }^{103}$. É nesse contexto que, em 1892, pouco antes da eleições, esses republicanos moderados são confrontados com o caso do Panamá.

Ferdinand de Lesseps, conhecido pela abertura do canal de Suez, formou em 1881 uma "Compagnie universelle du canal inter-océanique" para a abertura do istmo do Panamá. Como era necessário obter uma votação favorável na Câmara, a companhia “comprou” alguns deputados, operação que veio a público e revoltou a opinião pública. A resposta ficou restrita à queda do ministério de Émile Loubet, e o então presidente Sadi Carnot nomeia em dezembro Alexandre Ribot como primeiro ministro.

Esse processo de ralliement, juntamente com a tentativa de manter a República diante da crise do Panamá, acabou por construir um quadro conservador na Républica dos progressistas, segundo Démier. Bem diferente daqueles que fundaram a Terceira República, como Gambetta, e mesmo Ferry ${ }^{104}$, já que agora fazem parte do eleitorado progressista, os conservadores e católicos. Esse novo eleitorado e o temor de um movimento social no modelo do boulangismo abrem espaço para governos mais preocupados com a manutenção da ordem social do que com qualquer tipo de transformação. Os governos de Sadi Carnot (1887-1894), Casimir-Perier (1894-1895) e Félix Faure (1895-1899) seguiram essa mesma lógica de contenção. Essa política de contenção explica-se também pela radicalização da esquerda, principalmente com os movimentos sindicalistas e anarquistas. É em meio a esse período turbulento que a onda de antissemitismo avança e em 1894 a crise toma uma dimensão inaudita com o caso Dreyfus.

O que nos interessa aqui, particularmente, é a forma como France trata desse quadro político e social em Les Opinions, livro que segundo o prefácio do autor "nous aideraient à faire notre examen de conscience" (OJC, 1987, p. 221) em meio a um mundo repleto de injustiças. No capítulo em que discute com Roman e Gentil sobre o "affaire du Mississipi", o tempo da enunciação e da matéria enunciada se articulam

103 Segundo Démier, o eleitorado católico votou mais nos republicanos moderados, os "progressistes", que obtiveram em 1893 trezentos assentos, enquanto os radicais ficaram com pouco mais de cem representantes.

${ }^{104}$ Apesar das leis pela laicização do ensino, Ferry foi muito criticado pela sua política externa. Ver nota de Bancquart (1987, p. 1145). 
integrando a dualidade temporal ao sistema filosófico do personagem Coignard. Segundo a concepção do abade, os dois eventos dizem respeito aos mesmos homens, tratam dos mesmos preconceitos e dos mesmos erros. A companhia que "était accusée d'avoir corrompu les officiers du royaume et du roi "(OJC, 1987, p. 239) equivale à empresa de Lesseps que comprou os deputados da Terceira República para aprovar seu projeto. À junção dos dois tempos na narrativa histórica, agrega-se a compreensão cética do mundo, enunciando aqui o tempo satírico de France. Um tempo no qual os eventos se repetem incessantemente.

Essa concepção cíclica do tempo autoriza o narrador a tratar um evento histórico como exemplar, como é o caso da "Mme Cottu". Trata-se da breve história da "dame de La Morangère", a equivalente ficcional da "Mme Cottu", esposa do barão Cottu, um dos administradores acusado e preso por envolvimento no escândalo. Madame Cottu denunciou uma proposta feita pelo diretor da "Sûreté générale"105, Soinoury, que propunha a soltura de seu marido mediante o comprometimento do barão em denunciar deputados da direita que teriam recebido a propina, numa espécie de tentativa de equilibrar as acusações entre progressistas e tradicionalistas. Madame Cottu denuncia essa tentativa de Soinoury no tribunal, o que causa um escândalo nacional e leva à demissão do diretor do serviço de informação. Vejamos como o narrador anatoliano conta o evento:

"À l'une des audiences de ce procès mémorable, la dame de La Morangère, femme d'un des directeurs de la Compagnie du Mississipi, fut entendue en la grand-chambre par messieurs du Parlement. Elle déposa qu'un sieur Lescot, secrétaire de M. le lieutenant criminel, l'ayant mandée secrètement au Châtelet, lui fit sentir qu'il ne dépendait que d'elle de sauver son mari, qui était bel homme et de bonne mine. Il lui avait parlé à peu près en ces termes : 'Madame, ce qui fâche les vrais amis du roi en cette affaire, c'est que les jansénistes n'y sont point impliqués. Ces jansénistes sont des ennemis de la couronne autant que de la religion. Donnez-nous, madame, les moyens de perdre l'un d'eux, et nous reconnaîtrons ce service d'État en vous rendant votre mari avec tous ses biens.' Quand Mme de La Morangère eut rapporté ce discours, qui n'était pas fait pour le public, M. le président du Parlement fut obligé d'appeler en la grand-chambre le sieur Lescot, qui d'abord essaya de nier. Mais Mme de La Morangère avait de beaux yeux limpides, dont il ne put soutenir le regard. Il se troubla et fut confondu. C'était un grand vilain homme roux, comme Judas Iscariote." (OJC, 1987, p. 239-240)

Em primeiro lugar, o narrador, no intuito de aproximar os acontecimentos do mundo religioso de Coignard, substitui os deputados de direita do escândalo do Panamá

\footnotetext{
${ }^{105}$ Antigo serviço de informação e de vigilância policial.
} 
pelos jansenistas. Em segundo lugar, no que tange à transposição da história da madame Cottu para "la dame de la Morangère", ela é realizada por uma mistura de descrição, diálogo e, principalmente, por uma polarização entre a bondade da vítima e a vilania do subornador, como num quadro melodramático.

\section{Pastiche melodramático e eliminação da intriga}

Nesse transplantar da vida política para a ficção, o narrador transcreve "à peu près" as palavras de Lescot, que busca incriminar os jansenistas, inimigos da coroa e da religião. Madame de La Morangère denuncia, então, a situação e com seus "belos olhos límpidos" força a confissão do senhor Lescot, que se perturba e se confunde. O motivo da confissão de Lescot foi, segundo o narrador, a honestidade dessa senhora cujos olhos deixam entrever a verdade. Em oposição tanto ao belo homem como à mulher honesta, o narrador posiciona Lescot, esse "grand vilain homme roux", e o compara a Judas Iscariote, um traidor. As características físicas dos personagens dão detalhes ao leitor da imagem do quadro que o narrador apresenta. Temos o homem de boa aparência situado fora do quadro, a mulher de olhar puro e o vilão dentro da moldura da cena. Nesta cena melodramática ${ }^{106}$, os lados nos parecem definidos a priori.

Ainda que France utilize um "tableau" melodramático na composição desta cena, a estrutura geral do capítulo não segue a mesma orientação. Parece-nos que a construção melodramática do trecho funciona mais como um pastiche do que como parte da estrutura da obra. Uma frase depois da descrição dessa cena sugere tal suposição, quando o narrador afirma que o caso, "connue par les gazettes, fit l'entretien de Paris" (OJC, 1987, p. 240). As gazetas, periódicos em geral em formato de tablóide e de tom sensacionalista, teriam sido o meio de divulgação dos acontecimentos, certamente em um tom semelhante ao melodramático usado pelo narrador para falar do caso. Além disso, a sobriedade do narrador contrasta com os recursos melodramáticos e sensacionalistas dos quais ele utiliza. O caráter monográfico da obra, repleto de digressões e debates, contrasta com as referências escolhidas pelo narrador, e na contradição, reside o indício do pastiche.

${ }^{106} \mathrm{O}$ resumo do enredo típico do melodrama: uma sociedade em equilíbrio é transformada pela presença do traidor que acusa o herói de um crime do qual este último não pode se defender. $\mathrm{O}$ acontecimento altera toda a vida local e todo o decorrer da história é a narração desta luta pelo reconhecimento da virtude e da verdade. O enredo do melodrama é simples e Peter Brooks (1995) desenvolveu a partir dessa estrutura um modo de imaginação melodramático, cujas características mais importantes são: a busca do reconhecimento da virtude e da verdade, uma estrutura maniqueísta geral e a constituição de uma espécie de "tableau vivant". Para mais detalhes, ver Almeida (2009). 
Logo após a descrição desta cena, é o narrador Tournebroche que toma a palavra e transfere os acontecimentos para o local onde se encontra Coignard, apresentando os outros dois personagens desse quadro: "Nous troûvames dans la boutique le secrétaire particulier d'un ministre d'État, M. Gentil, [...] et le célèbre M. Roman, qui a traité de la raison d'État en divers ouvrages estimés. Le vieux M. Blaizot [...] lisait la gazette.” Novamente a referência à gazeta reforça o imaginário que o caso evocava, mas no diálogo entre os personagens, o tom melodramático se esvai. O motivo inicial da conversa é uma fala de Coignard que, olhando as notícias sobre os ombros de Blaizot, lê o testemunho da dama de La Morangère e elogia a sua atitude, essa dama que "plait par un rare mélange de droiture et de finesse" (OJC, 1987, p.241). Agora, ela não é mais a mulher de belos olhos límpidos, mas honesta e fina. As características físicas dão lugar às morais, assim como o melodramático se transforma em diálogo de ideias.

O sr. Roman, como defensor da razão de Estado, argumenta que a admiração de Coignard pela tal dama é consequência de um olhar individual e particular sobre o caso, sem levar em conta os interesses públicos aí presentes. Para ele, "il faut voir em tout la raison d'État", e, por isso Madame de La Morangère não deveria ter revelado a tentativa de extorsão. O sr. Gentil, secretário ministerial, afirma primeiro que a importância do caso foi superestimada, mas logo concorda com Roman, e lembra que esse evento "insignifiant" pode lhe custar o emprego. Roman faz então uma analogia interessante: “L'État est comme le corps humain”. E, assim como o corpo humano tem funções não nobres, as quais se que deve esconder; o mesmo se daria com o Estado.

Coignard pergunta, então, se nesse contexto era ainda necessária a chantagem de Lescot. Roman responde que a ação só foi infame quando se tomou conhecimento dela, “avant, ce n'était rien”. A primeira forma de exercício do poder pelos governantes, segundo Roman, é o segredo; assim se explica a fraqueza de um governo popular, "qui est le moins secret de tous, en est aussi le plus faible" (p.242). Neste diálogo, ainda que o personagem de Roman não seja caricaturizado como foi o caso do capuchinho Ange, os seus argumentos ajudam a formar, do ponto de vista ideológico, um tipo nacionalista. O estigma passa da ignorância para a posição ideológica. A conversa continua e o tom vai se elevando depois de Coignard afirmar que um governo que deixa de lado a "médiocre et commune honnêteté" e escandaliza as pessoas, deve ser deposto. O temeroso Gentil pede ao religioso que fale mais baixo e Roman ataca Coignard qualificando-o como um rebelde que não merece mais ser governado. Assim como 
Roman, Gentil, cujo nome revela a ironia do narrador, representa também um tipo, o tipo burocrata, medroso e ligado ao poder, o tipo do funcionário público, opondo-se, como o nacionalista Roman, ao polemista Coignard.

A elevação do tom do debate é o que faz com que Coignard acabe se contradizendo: enquanto na conversa com Hibou, ele dissera que a um mau governo sucederia um ainda pior, "à un mauvais succédait un pire" (OJC, 1987, p. 237), no colóquio com Roman e Gentil, ele inverte o argumento dizendo que "les nouveaux ne pourraient être plus mauvais que les anciens" (p. 242). Roman volta a defender a continuidade de governo, enquanto Coignard diz que nesses momentos ele não sabe o que é mais admirável, o cinismo dos governos ou a paciência do povo. Gentil se indigna com o fato de Coignard não saiba observar os acertos do governo e Blaizot diz que sua livraria não é local de disputa de questões públicas. Todos saem da livraria, e nesse momento Tournebroche aponta a contradição do seu mestre que responde afirmando ser o seu desacordo somente aparência: ele pensa ainda como antes, mas deixou-se levar pelo coração e cedeu à paixão.

A estrutura dialógica da obra, diferentemente do tom picaresco das aventuras de La Rôtisserie, faz-nos perguntar se o processo de caricaturização que vimos com Ange ainda faz sentido aqui. Num trecho sobre o "affaire Mississipi", o narrador dá a voz a outros personagens além de Coignard, mas antes de passar a palavra, ele fornece ao leitor o local de enunciação do debatedor. No caso de Roman, trata-se de um escritor que "a traité de la raison d’État en divers ouvrages estimés" (p. 240). O uso do adjetivo "estimés" nos parece indicar uma interferência da ironia anatoliana representando o senso comum, aquilo que "le vulgaire" acredita ser correto. Sobre Gentil, o próprio nome, como dissemos, denota a ironia do narrador, aquele que agrada, um homem amável, um secretário ministerial, figura passiva que só se insere no debate para tentar acalmar os ânimos. Já o carismático Coignard, apesar de suas contradições e excesso de erudição, nunca é avaliado pela sua imagem, nem pela sua função ou posição social. Ele continua sendo o personagem cativante, construído a partir das aventuras do romance anterior.

Portanto, ainda que dê voz ao outro, o narrador continua rotulando esse outro, transformando-o numa espécie de ilustração ideológica de um tipo. Temos no diálogo o tipo burocrata, Gentil, o tipo nacionalista, Roman, e o humanista Coignard. Essa construção de tipos mais ideologicamente delimitados aparece com mais força nos 
romances de France a partir de Les Opinions, uma concepção do mundo que antecede a representação. As ideias é que devem ser discutidas e o arranjo do narrador serve a esse propósito: apresentar os acontecimentos e discuti-los a partir de posicionamentos claros.

No que diz respeito à estrutura geral do livro, tomando como exemplo o quarto capítulo do livro, sobre o "affaire du Mississipi", há uma introdução geral ao caso, um evento específico e uma discussão acerca da relação entre o caso individual e a razão de Estado $^{107}$. É o mesmo movimento, alternando a atualidade e o exame da ordem social, que se dará na série de romances do sr. Bergeret. Esse modelo é em grande parte resultado da influência do cronista sobre o romancista, pois as crônicas publicadas em L'Écho são reaproveitadas para o romance, sendo as modificações apontadas nas notas de Bancquart. A influência dos acontecimentos na escrita do romance era, portanto, direta. Muito em função dessa premência da atualidade numa obra que se escreve diariamente, a intriga, diferentemente de La Rôtisserie, anula-se, como bem observa a crítica e especialista na obra anatoliana: “L'oeuvre s'écrit au jour le jour. Elle est méditation, monologue, discussion; l'intrigue y est nulle." (Bancquart, 1987, p. 1118).

O interessante de observar nesse momento de transição na obra de France é o que ele escolhe da atualidade para narrar e discutir. No caso do escândalo do Panamá, o narrador usa um pastiche melodramático para falar da história da dama de La Morangère, ao mesmo tempo em que os diálogos tratam de debates mais filosóficos, como é o caso da discussão sobre a razão de Estado versus o indivíduo. Porém, o pastiche é eventual, o que não acontece com a estrutura dialogal, cuja presença vai se tornando cada vez mais presente. As discussões na livraria vão tomando, assim, o espaço da intriga, ainda que o aspecto mais anedótico permaneça eventualmente como ilustração da realidade.

Ao tratar da relação dos romances de France com a história, não é possível deixar de lado o exame do romance histórico Les Dieux ont soif por Georg Lukács. O crítico observa em France um tipo de ceticismo humanista e militante que resgata os valores iluministas. Talvez uma mistura de Voltaire e Renan com um ceticismo peculiar. Segundo Lukács, como filho de sua época, France compreendeu como poucos as contradições históricas de seu tempo, sem que essas questões fossem tratadas em termos românticos ou melodramáticos. Também segundo o crítico, é a ironia de seu narrador que permite essa realização; ela é necessária para consolidar um protesto

${ }^{107}$ Esta questão está na base dos acontecimentos do caso Dreyfus. 
humanista contra o estado das coisas: "the epicurean wisdow and detachment reflect a refusal, veiled in irony and humor, to enter into or alter the hostility and meanness of social reality." (Lucáks, 1983, p. 330). A posição distanciada do narrador irônico é o que permite, segundo Lukács, a consolidação de um protesto humanista em France. O exame de France por Lukács se insere no estudo da trajetória do romance histórico desde o nascimento inglês com Walter Scott. Para o teórico marxista, France conseguiu traduzir em palavras o aspecto contraditório das ações humanas em sua "profunda e inalterável compaixão".

Mais do que a escrita da história, o que nos parece integrar a narrativa anatoliana a partir de Les Opinions é a atualidade dos temas ali tratados. O pastiche melodramático recupera o lado anedótico e jocoso do escritor, inspirado no modelo das gazetas, enquanto a ironia persegue os tipos agora elevados a agentes do diálogo e do debate acerca das ideias correntes neste tempo duplicado do romance. Diante de sua modernidade, porém, nos perguntamo porque estaria então este autor tão olvidado? Uma possível resposta para tal indagação diz respeito às questões formais da escrita anatoliana. France não buscou traduzir formalmente suas inquietações sociais, característica das mais relevantes do modernismo literário. Sua linguagem permaneceu límpida, a fala dos personagens não sofreu alterações substanciais. Porém, ainda que o quadro crítico exclua hoje a contribuição desse autor ${ }^{108}$, France continua atual nas indagações e inquietações que circundam suas obras, principalmente pelas escolhas narrativas que tiveram grande influência não somente na formação do herói intelectual, como na formação de um narrador humanista e engajado no seu tempo. France foi um escritor filho do seu tempo e muitas das suas críticas não pereceram na sua posteridade.

\section{A contaminação jornalística do cronista}

Para tratar da presença jornalística na obra de Lima Barreto, retomaremos o romance Isaías Caminha, mais especificamente a Revolta dos Sapatos Obrigatórios, evento romanceado que guarda estreitas relações com a Revolta da Vacina ${ }^{109}$. A revolta aparece anunciada no décimo capítulo do livro, mas a descrição dos acontecimentos só

${ }^{108} \mathrm{Na}$ introdução à edição de Historical Novel, de 1983, Fredric Jameson afirma que a parte do livro na qual Lukács trata de Anatole France, dentre outros como Heinrich Mann e Romain Rolland, é a mais datada de todas, menos pela análise e mais pelas referências.

${ }^{109}$ A relação é fruto da semelhança dos acontecimentos reais com os do romance. Ainda que as datas não sejam as mesmas, a sugestão da lembrança recente pelos leitores, a descrição do motim e da repressão são suficientes para a compreensão da versão romanceada como representação dos acontecimentos reais. 
se dá dois capítulos à frente, postergação que já enuncia um dos procedimentos narrativos. Nessa postergação, há um jogo que é sugerido pelo narrador ao tratar das verrinas presentes nos apedidos do Jornal do Commercio:

"Causava pasmo o esforço de imaginação despendido em se obter circunlóquios bastante claros para serem compreendidos no seu verdadeiro sentido por toda a gente e bastante velados para não haver impedimento na sua publicação." (IC, 2010, p. 221).

O jogo do "mostrar e esconder" aparece como um recurso que tem origem nos execrados apedidos jornalísticos, que acabam contaminando a linguagem romanesca. A atenção particular que o narrador dá aos apedidos aparece em meio a uma disputa entre o jornal e a prefeitura acerca de um empréstimo feito pelo poder público. Isaías, que sabe do assunto por Plínio de Andrade - na chave de Noronha Santos, versão romanesca do próprio Lima Barreto -, comenta a situação: "O pomo de discórdia residia na comissão do lançamento do empréstimo, e sendo esta avultada [...] permitia gordas gorjetas aos jornalistas e políticos". (p. 218). O assunto era então debatido fervorosamente no jornal e quase todos os dias o diário publicava algumas linhas contrariando o lançamento do grande empréstimo ${ }^{110}$.

E é nos apedidos que o embate era interessante, segundo o narrador, pois aí apareciam todos os tipos de artigos: “... sisudos, cheios de citações, Léon Say, LeroyBeaulieu, versos de Racine". (p. 220). O mesmo espaço jornalístico que influencia a linguagem romanesca no jogo do mostrar e revelar - nesse sentido escondendo parte do real - também se configura como um espaço de maior liberdade para o escritor. Remete-nos, também, à contaminação das gazetas, na descrição de Mme Cottu, que vimos há pouco, assim como guarda semelhanças com a forma que a crônica adotou no Brasil.

Ao refletir sobre a adaptação desse gênero no Brasil, Antonio Candido chega à conclusão de que a crônica brasileira (bem realizada) "participa de uma língua geral lírica, irônica, casual, ora precisa e ora vaga, amparada por um diálogo rápido e certeiro, ou por uma espécie de monólogo comunicativo" (Candido, 1992, p. 22). Assim como a escrita anedótico-jornalística de France agradava, em geral, ao público leitor francês da época, a adaptabilidade formal da crônica no Brasil revela um apreço semelhante do

110 Sabe-se que para atender às necessidades de modernização da cidade do Rio de Janeiro, o governo de Rodrigues Alves (1903-1907) deu carta branca para o prefeito Pereira Passos remodelar a capital. Obra prioritária para o governo, a remodelação e o saneamento do Rio de Janeiro foi realizada com o desalojamento de uma considerável parcela da população pobre do centro da cidade. 
leitor brasileiro por uma escrita que trate de assuntos densos com ironia, casualidade, lirismo. Dessa forma, o ato informativo-reflexivo e diversificado do jornalismo que aparece nos apedidos - e do qual o narrador se apropria - configura-se nesse capítulo como uma expressão dessa escrita liberta das restrições formais ou poéticas, e ao mesmo tempo, uma forma velada de revelar os acontecimentos, no jogo de revelar e esconder, assim como fora o jogo que "edifica e destrói os impérios", realizado por Racine e elogiado pelo narrador-comentador de Les Opinions.

Esse lado falseado ou velado da realidade remete em Barreto à denúncia do falso, nos indícios de um tipo de narrativa que se propõe informativa, mas que não passa de um jogo de linguagem ${ }^{111}$. Esse lado pernicioso da incorporação do ficcional ao jornalístico reporta-nos à contestação, por Lima Barreto, da validade da linguagem posta pela tradição acadêmica, do efeito nocivo do retoricismo na linguagem. No que diz respeito aos acontecimentos da Revolta da Vacina, Barreto comenta no Diário Íntimo os eventos do mês de novembro de 1904, as "mazorcas de novembro", elogiando as vantagens da revolta: a redução do "fetichismo da farda", além da demonstração de que a cidade "pode ter opinião e defendê-la com armas na mão" (PS, 2006, p. 1222). No Diário, Barreto continua a tratar do motim nos dias que se seguem (sem data) até que, no dia 22, portanto, oito depois do fracasso da revolta, controlada com uma violência inaudita, ele descreve um encontro com o ministro da Guerra, Francisco de Paula Argolo. À violência do massacre, Barreto opõe o "aspecto encantador" do malogro do povo. É nessa situação que Barreto denuncia a linguagem de Rui Barbosa.

"Rui, o letrado beneditino das coisas de gramática, artificiosamente artista e estilista, aconselha pelos jornais condutas ao governo. Há dias, ele, no auge da retórica, perpetrou uma extraordinária mentira. Referindo-se ao dia 14, que fora cheio de apreensões, de revoltas e levantes, e à nota trazida a 15 , da vitória da 'legalidade', disse assim, da manhã de 15: 'fresca, azulada e radiante', quando toda a gente sabe que essa manhã foi chuvosa, ventosa e hedionda." (PS, 2006, p. 1225).

O que o olhar crítico de Barreto capta no discurso de Rui Barbosa é o descolamento entre o real e a imagem do real. Rui Barbosa, no seu discurso, relaciona a imagem de legalidade a de uma manhã "fresca, azulada e radiante". A associação entre a bela imagem da manhã e a vitória da legalidade se dá no plano das imagens, enquanto

${ }^{111}$ No que diz respeito a esse jogo, o narrador anatoliano parece dar ao procedimento um viés positivo, enquanto em Barreto, a denúncia do falso na linguagem o leva a adotar uma postura mais desconfiada em relação ao jogo de "mostrar e esconder", particularmente porque a sua denúncia envolve a própria linguagem, não somente uma situação social, como é o caso de France. 
o real, a manhã chuvosa e ventosa na qual a revolta foi reprimida violentamente, é escondido. Esse tipo de denúncia nos remete ao embelezado mendigo de Anatole France no romance $M$. Bergeret à Paris, no trecho em que o narrador trata das reflexões do professor Bergeret ${ }^{112}$ acerca da esmola. É o primeiro dia do ano, e Bergeret e sua filha Pauline estão se dirigindo à casa de uma tia, quando passam por alguns mendigos nas ruas. No trajeto, chama atenção a ironia do narrador ao descrever o percurso por onde passaram: "Le long des voies, les mendiants, dressés comme des candélabres ou étalés comme des reposoirs, faisaient l'ornement de cette fête sociale" (MBP, 1991, p. 286).

Dois elementos chamam a atenção neste trecho: em primeiro lugar, a posição de candelabro que confere uma qualidade de objeto de decoração ao mendigo; em segundo, a sacralização da rua, elemento que poderia ser positivo em muitos autores, mas não no anticlerical Anatole France. A ironia do narrador está não somente na transformação do cenário real como na denúncia social, a partir do uso de um campo semântico religioso (candelabros, hostiário). Não nos parece fortuita, nesse contexto, a alusão de Barreto a Anatole France no Diário Íntimo, no mesmo ano de 1904; uma frase do deputado Garain, no romance Le Lys rouge ${ }^{113}$ :

Toute idée fausse est dangereuse. On croit que les rêveurs ne font point de mal, on se trompe, ils en font beaucoup. Les utopies les plus inoffensives en apparence exercent réellement une action nuisible. Elles tendent á inspirer le dégoût de la réalité. (LR, 1987, p. 358).

$\mathrm{O}$ perigo das ideias falsas notado pelo personagem anatoliano reforça o argumento limabarretiano do falseamento do real. Vejamos, porém, quem é o personagem que profere a frase no romance de Anatole France. Na obra, o diálogo no qual Garain, ex-ministro da Justiça, profere a frase acima, se dá durante um jantar na residência dos Martin-Bellème. O conde Martin-Bellème é neto do conde Martin de l'Aisne que fizera parte do governo de Napoleão como deputado, mas fora repreendido pelo Imperador pela inclusão de um girondino no corpo legislativo do Império, grupo político que depois se tornaria opositor ao regime napoleônico. Sua família carrega, em função da admoestação ao Imperador, um “tremblement héréditaire” (LR, 1987, p. 357). A ironia do narrador é clara e ele comenta cada personagem. Enquanto o aristocrata

$112 \mathrm{O}$ sr. Bergeret é "maître de conférences à la faculté des lettres", e se torna professor titular no terceiro volume da série. Ver nota de Marie-Claire Bancquart (1991, p. 1193). Trataremos mais detalhadamente desse romance nos últimos capítulos dessa segunda parte da tese.

${ }^{113}$ Esse romance saiu na Revue de Paris em cinco partes, de abril a junho de 1894. A edição original foi publicada pela Calmann-Lévy no mesmo ano. Com a ajuda de Gaston de Caillavet, France cria uma versão teatral do romance em quatro atos. A peça foi representada em 1899 em meio aos acontecimentos do caso Dreyfus. 
carrega no sangue o temor diante das transformações políticas, Garain teme o futuro. Este homem, que sob o Império havia requisitado a supressão dos exércitos permanentes e a separação entre Igreja e Estado, posição próxima à do escritor Anatole France, agora "la peur éclatait soudaine et féroce" (p. 361). Assim como muitos dos personagens presentes na cena, Garain também se distanciou de seus antigos projetos. É neste contexto que a frase acima deve ser lida. A desilusão de Garain reflete os desencantos com a República vindos de um republicano.

Lima Barreto, que certamente conhecia o romance, apropria-se também dessa desilusão frente à realidade política, que no Brasil estava também sob a névoa do bacharelismo e do descolamento em relação à realidade das pessoas, como o autor enuncia a partir da referência ao discurso de Rui Barbosa. Diferentemente do procedimento anatoliano de construção de argumentos a partir dos discursos dos personagens, Barreto foca na linguagem, como forma de denúncia diante de um real duplamente falseado, nos acontecimentos e na construção formal. Como um cronista escritor de romances, Lima Barreto resgata, como France, os elementos mais leves e jogosos do gênero, mas, ao contrário do escritor francês, o faz também por meio da denúncia da linguagem de seus pares. Disto resulta, em parte, a atualidade de sua obra, que se voltou também para uma alteração no estilo de escrita.

\section{Sensacionalismo e literatura militante}

Voltando à "questão dos sapatos obrigatórios", ela aparece pela primeira vez no romance no momento de embate entre o jornal e o poder público, evento do qual, como lembra o narrador, muitos dos leitores "ainda se recordam perfeitamente" (IC, 2010, p. 222). A circunstância que o narrador escolhe para tratar dessa questão não é selecionada ao acaso, pois esse é o último verdadeiro embate do jornal antes da assimilação pelo poder, com a atenuação do espaço crítico nas suas páginas e a migração dos jornalistas para ofícios públicos, explicitando cada vez mais a relação incestuosa entre o jornal e o poder político. Vejamos como o narrador introduz a "questão dos sapatos obrigatórios":

Nascera a questão dos sapatos obrigatórios de um projeto do Conselho Municipal, que foi aprovado e sancionado, determinando que todos os transeuntes da cidade, todos que saíssem à rua seriam obrigados a vir calçados. Nós passávamos então por uma dessas crises de elegância, que, de quando em quando, nos visita. Estávamos fatigados da nossa mediania, do nosso relaxamento; a visão de Buenos Aires, muito limpa, catita, elegante, provocava-nos e enchia-nos de loucos desejos de igualá-la. Havia nisso uma grande questão de amor-próprio nacional e um estulto desejo de não permitir que os estrangeiros, ao 
voltarem, enchessem de críticas a nossa cidade e a nossa civilização. Nós invejávamos Buenos Aires imbecilmente. Era como se um literato tivesse inveja dos carros e dos cavalos de um banqueiro. (IC, 2010, p. 223).

A lei dos sapatos obrigatórios entra no romance no rol de medidas tomadas pelo prefeito Pereira Passos, juntamente com o Diretor Geral de Saúde Pública, o dr. Osvaldo Cruz, responsável pela defesa sanitária da cidade do Rio de Janeiro. Edgard Carone (1979) elenca algumas das medidas da época: proibição que os bandos de vacas percorram as ruas da cidade, do comércio de bilhetes de loteria, da perambulação de mendigos pela cidade, sem falar na campanha pela extinção dos cães vadios. O teor inusitado de uma lei dos sapatos obrigatórios não se trata de um exagero, mas de uma ironia diante da excentricidade do real. Ao tratar da lei, o narrador inicia com uma espécie de lead jornalístico, explicando que a questão nasceu de um projeto do Conselho Municipal, aprovado e sancionado, e que determinava que "todos que saíssem à rua seriam obrigados a vir calçados". Até aí, o discurso jornalístico é transposto tal qual o esperado. O que vem na sequência, porém, não somente ironiza como critica as razões da lei.

Para explicar essa lei, o narrador limabarretiano afirma na sequência que naquele momento, nós, do Brasil, passávamos por "uma dessas crises de elegância, que, de quando em quando, nos visita". Daí a comparação com Buenos Aires e o sentimento de inferioridade do carioca diante da capital argentina: "Nós invejávamos Buenos Aires imbecilmente". O termo "imbecilmente" na oração, ao revelar uma intromissão do narrador, introduz também uma inusitada comparação: "Era como se um literato tivesse inveja dos carros e dos cavalos de um banqueiro". O lead está suspenso, assim como a narrativa jornalística, e o que percebemos é a entrada do satirista na narrativa, primeiramente aproximando ironicamente a Argentina e o Brasil, e na sequência, com as opiniões dos colegas de jornal, acompanhando o mesmo percurso de caricaturização que traçamos no capítulo anterior. O tom jornalístico, porém, é recuperado na sequência como uma espécie de resumo do "estado de espírito que ditou o famoso projeto dos sapatos:

E os da frente, os cinco mil de cima, esforçavam-se por obter as medidas legislativas favoráveis à transformação da cidade e ao enriquecimento dos patrimônios respectivos com indenizações fabulosas e especulações sobre terrenos. Os Hausmanns pululavam. Projetavam-se avenidas; abriam-se nas plantas squares, delineavam-se palácios, e, como complemento, queriam também uma população catita, limpinha, elegante e branca: cocheiros irrepreensíveis, 
engraxates de libré, criadas louras, de olhos azuis, com o uniforme como se viam nos jornais da moda da Inglaterra. Foi esse estado de espírito que ditou o famoso projeto dos sapatos." (IC, 2010, p. 224)

A lei dos sapatos obrigatórios é interpretada pelo narrador como um complemento ao novo projeto de urbanização da cidade e ao enriquecimento dos "cinco mil de cima". Por sua vez, o complemento aos palácios e às grandes avenidas estaria na população limpa, elegante e branca. O lead dá lugar aqui a um tom de articulista, que interpreta o real. O narrador não parte mais da situação, mas de equivalências. Essas equivalências, por sua vez, levam à mesma crítica da realidade construída, já que a intenção embelezadora da lei tinha o intuito de criar uma realidade "como se viam nos jornais da moda da Inglaterra", era esse o "estado de espírito" do projeto.

Quanto às orações do trecho, chama a atenção o caráter enunciativo da descrição, os Hausmanns pululavam, as avenidas eram projetadas e abertas, os palácios delineados. Para esse estado acelerado de transformações esperavam-se cocheiros irrepreensíveis, engraxates de libré, criadas louras de olhos azuis. A veia jornalística do narrador entra então em ação nas frases simples e diretas. Ao mesmo tempo, o estilo enumerativo acompanha o próprio movimento da cidade, numa equivalência entre a linguagem e os acontecimentos. Observa-se, neste trecho iniciado com "Os Haussmanns pululavam" a concentração dos verbos indicando um movimento contínuo. Já nos complementos, no que diz respeito à população catita, a listagem desprende-se dos verbos e se centra nos adjetivos. A "população catita, limpinha, elegante e branca" fica inerte diante das transformações, repetindo o percurso do próprio Isaías. À transformação do espaço público marcada pelos verbos sequenciais, o narrador associa o embelezamento do real, centrando a descrição nas qualidades deste imaginário.

O projeto, porém, não recebe atenção: “Ao ser apresentado, ninguém lhe deu importância, mesmo porque dias antes houvera um crime sensacional que monopolizara a atenção da cidade" (p. 224). O desinteresse em prol do "crime sensacional" reproduz a mesma lógica das gazetas de France e dos apedidos de Barreto. Uma denúncia da realidade transformada em acontecimento sensacional. Esse aspecto de denúncia, que parte da crítica a um tipo de jornalismo, surge ligado a um momento de transição da pequena à grande imprensa. Nelson Werneck Sodré lembra que a passagem do século no Brasil assinala "a transição da pequena à grande imprensa" (Sodré, 2011, p.405) ${ }^{114}$.

114 A dimensão pessoal dos fatos políticos, ressaltada por Barreto nas parcialidades dos jornalistas, também é lembrada por Sodré neste momento de consolidação da grande imprensa no Brasil. 
Este aspecto de denúncia do real na sua ficcionalização nos parece ser uma das características mais relevantes da literatura militante defendida por Lima Barreto e inspirada em Anatole France, cujo modelo Racine já enunciara. Vejamos como o escritor brasileiro descreve o que chamou de literatura militante. No jornal A.B.C., do dia 7 de setembro de $1918^{115}$, em uma crítica a um artigo de Carlos Malheiro (18751941), escritor português, autor de obras como A mulata, de 1896, Barreto define a literatura de Anatole France, a "grande literatura", como militante:

"A começar por Anatole France, a grande literatura tem sido militante.

Não sei como o Senhor Malheiro Dias poderá classificar a Ilha dos Pingüins, os Bergerets, e mais alguns livros do grande mestre francês, senão dessa maneira.

Êles nada têm de contemplativos, de plásticos, de incolores. Tôdas, ou quase todas as suas obras, se não visam a propaganda de um credo social, têm por mira um escopo sociológico. Militam.” (IL, 1956, p. 72)

A definição de literatura militante está vinculada à escrita anatoliana. Já falamos sobre a interpretação peculiar de Barreto da obra de Anatole France, em oposição à maioria de seus contemporâneos que viram no escritor francês somente o sensualista da ironia e piedade. Já vimos também a referência a Anatole France no texto de Mirassol, uma espécie de testamento literário de Lima Barreto, no qual ele lembra do conto Crainquebille como um dos clássicos da literatura mundial. No caso da literatura militante, repete-se aquilo que vimos na prevalência da ética sobre a estética dos prefácios. O fim da obra de arte determina a sua avaliação: ou os livros de France "visam a propaganda de um credo social" ou almejam "um escopo sociológico".

Um dos fatores que permitem o olhar diferenciado do narrador diante dos elementos da realidade tratados na obra literária e do autor diante da arte, reside na posição de enunciação destes narradores, em sintonia com o aspecto autoral e com a configuração do herói intelectual. Nos respectivos ambientes literários, a posição autoral de France e Barreto é de independência, seja em relação às correntes literárias, seja em relação às vertentes ideológicas. Nas obras, isto parece se refletir num ponto de vista particular na observação e seleção do real.

A essa posição de independência, é possível associar o método desta literatura militante: a clareza. No prefácio a Impressões de Leitura, Cavalcanti Proença ressalta a busca de clareza na obra de Barreto, formalizada numa "certa abundância de

\footnotetext{
${ }^{115}$ Depois reunido no volume Impressões de Leitura.
} 
enumerações". Num dos textos da série La Vie Littéraire ${ }^{116}$, France elogia Maupassant afirmando que ele possui "les trois grandes qualités de l'écrivain français, d'abord la clarté, puis encore la clarté et enfin la clarté” (VL1, 1925, p. 54-55). A busca está diretamente associada à primazia da comunicação, o que retoma, de outro ângulo, a prevalência do fim da arte sobre seus meios. Vejamos este local de enunciação no episódio dos sapatos.

\section{Local de enunciação da literatura militante}

Entre o início da "questão dos sapatos obrigatórios" e o relato da Revolta, há um capítulo no qual o narrador limabarretiano descreve a casa de cômodos onde reside, um dos mais de vinte quartos de um antigo palacete, onde habitavam mais de cinquenta pessoas. Se a primeira interrupção da questão dos sapatos deu lugar ao relato sensacionalista e ao movimento acelerado da "fábrica de carapetões"; na segunda, do cortiço, no décimo primeiro capítulo, o narrador desacelera o ritmo da ação e nos conduz para o ambiente de onde eclodirá o motim, mostrando um espaço de pobreza, abandono, descrito com muito lirismo.

O efeito desta pausa na narrativa é um deslocamento temporal e espacial no romance, como se não somente o narrador nos retirasse do espaço do jornal, mas também do tempo acelerado que caracteriza o jornalismo sensacionalista. Além disso, a diminuição do ritmo da narrativa, juntamente com o saudosismo inicial que faz alusão ao passado glorioso do cortiço, têm como efeito não somente a preparação do leitor para os acontecimentos futuros, como é uma estratégia de ampliação do impacto dos dias de revolta - no contraste com a pacatez da descrição das origens do cortiço. Sobre a gente do cortiço, o narrador comenta: "Admirava-me que essa gente pudesse viver, lutando contra a forme, contra a moléstia e contra a civilização; que tivesse energia para viver cercada de tantos males, de tantas privações e dificuldades" (IC, 2010, p. 242).

Sevcenko (2010), ao analisar os acontecimentos da Revolta da Vacina, fala desses grandes casarões imperiais e coloniais divididos em diversos cubículos, as "zungas"117, que aparecem devido à enorme pressão por habitações numa cidade que

\footnotetext{
116 Trata-se de um artigo intitulado "M. Guy de Maupassante et les conteurs français".

117 "Desenvolvem-se, assim, os cortiços, as casas de cômodos ou 'zungas', onde o que se alugava era apenas uma esteira, disposta num salão aberto, em que se aboletavam dezenas de pessoas, em total promiscuidade, sem nenhum recurso higiênico ou sanitário.” (Sevcenko, 2010, p. 88)
} 
aumentou consideravelmente sua população entre 1890 e $1920^{118}$. O local para o qual o narrador conduz o leitor é a origem dos próximos acontecimentos, contrapondo um espaço de solidariedade na miséria ao ambiente hierárquico do jornal. Um espaço no qual o tempo tem um ritmo diferente da aceleração dos jornais.

O narrador Isaías instala-se a partir desse momento num espaço privilegiado em função da posição que ocupa na sociedade. Ele está situado no espaço entre dois mundos: o mundo pobre onde reside e de onde veio e o mundo do poder e do jornal, para onde se encaminhara. Deste espaço privilegiado, o leitor é conduzido de um ambiente de "privações e dificuldades" para o "feudo" jornalístico, onde "o diretor é uma espécie de senhor feudal a quem todos prestam vassalagem” (IC, 2010, p. 244). Feudo, porém, com aparência de democracia - talvez uma analogia à própria República. O importante é a polaridade social que é construída com essas oposições: povo versus jornal, jornal versus República, povo versus República . O narrador Isaías, em decorrência da posição de origem, é capaz de preparar esse ambiente de rivalidade, absolutamente apropriado para a representação mais viva da Revolta. Não que ele recrie essa oposição de forma a contrapor bem e mal, mas sim com vistas a posicionar o leitor nesse espaço privilegiado da narrativa, o local ideal para indignar-se contra a ordem estabelecida, o local de enunciação da literatura militante.

Não há como deixar de se reportar ao hors et là na obra de Anatole France, o escritor do mundo da cultura clássica e da sociedade de sua época (là), ao mesmo tempo proveniente de uma família pobre (hors), ciente de que nunca estaria totalmente adequado a nenhum desses dois ambientes. Essa inadequação, que resulta nos dois autores numa capacidade crítica particular, é que faz o narrador anatoliano ver ao mesmo tempo a "desinteligência" dos humildes e a tirania dos poderosos. Este mesmo local de enunciação crítico aparece também em outro momento de Isaías Caminha, quando o narrador fala sobra a sua posição diante do desembarque do redator português que vinha para trabalhar no jornal: "Inútil é dizer que fiquei de longe, sozinho, como sempre fiquei nessas coisas e como parece ser meu destino ficar sempre.” (IC, 2010, p. 249). E é por meio de Isaías, esse personagem-narrador que transita entre o cortiço e o jornal, que a revolta é contada ao leitor ${ }^{119}$.

${ }^{118}$ Em 1890, a população do Rio de Janeiro era de aproximadamente 876 mil pessoas. Esse número passa para um milhão e 160 mil pessoas em 1920. Dados IBGE (Estatísticas do Século XX, acessado em setembro de 2012, no site http://www.ibge.gov.br/seculoxx).

119 É importante ressaltar neste caso uma diferença entre France e Barreto. Enquanto o narrador anatoliano fala quase sempre de uma posição privilegiada e exterior, no caso de Isaías Caminha, a origem 
A história submersa da lei dos sapatos obrigatórios volta à tona quando o narrador sai de sua residência e a lavadeira, dona Felismina, pergunta a Caminha sobre a dita lei. Segundo Felismina, o que se fala nas ruas é que quem tivesse pé grande teria que passar por uma operação para a diminuição dos pés, “como os chinas ...” (p. 245). Ao se encaminhar para o jornal, o narrador deixa o eco do burburinho que o assunto vinha causando na população, e quando chega ao jornal encontra Floc redigindo uma notícia sobre a chegada do novo redator português ao periódico. Explica então o narrador que "nos jornais, os artigos impressionistas são sempre feitos antes das impressões" (p. 245) ${ }^{120}$. O que nos interessa marcar nessa constante postergação dos acontecimentos da revolta é que a questão dos sapatos é sempre referida, mas encoberta por algum outro evento, primeiramente o crime sensacionalista, depois a descrição do cortiço e, enfim, a chegada do redator português. Há um oscilar entre dois mundos no que diz respeito à dita questão: entre o povo e o jornal sensacionalista, entre o povo e o tirânico jornal, entre o povo e o estrangeiro ${ }^{121}$.

Vejamos, enfim, o relato da Revolta no décimo segundo capítulo do livro. O capítulo se inicia com a chegada do poeta Félix da Costa que traz um volume de versos para oferecer ao jornal. É Isaías quem o recebe e promete encaminhar o livro ao crítico Floc. $\mathrm{O}$ evento dá ensejo à denúncia dos clichês no universo da crítica literária e o narrador-satirista destrincha os meandros da atitude jornalística frente ao acolhimento de obras desconhecidas ${ }^{122}$. $\mathrm{O}$ assunto da revolta surge em meio a uma conversa na redação de $O$ Globo, a partir de um artigo publicado no Jornal do Commercio. A conversa se dá entre Abelardo Leiva, o poeta e revolucionário "que fazia polícia e 'Vida Operária"”; Losque, o humorista; Floc, o crítico e Gregoróvitch. O narrador conclui ao final que "todos previam um motim", quando é chamado por Loberant para entregar

pobre marcada pela vida no cortiço, dá ao narrador uma situação mais próxima aos humildes, privilegiada e interior.

${ }^{120}$ Essa contenção da descrição da Revolta que se mantém latente desde seu primeiro anúncio até sua efetiva exposição poderia ser sintetizada num oximoro usado por France em Crainquebille, "imobilité frémissante", termo que pretende descrever a tensão causada pelo engarrafamento que o personagem provoca nas ruas de Paris. Aqui também é possível falar de uma imobilidade trêmula na contenção dos acontecimentos da Revolta popular.

121 Importante lembrar que na Revolta da Vacina os levantes tiveram o apoio de camadas importantes da sociedade, como alguns jornais, grupos de militares e políticos, na sua maioria, positivistas. Ao isolar o povo nos acontecimentos, o narrador ressalta não somente o caráter popular do levante, como deixa entrever que a participação desses outros grupos nada tinha a ver efetivamente com os motivos populares.

${ }^{122} \mathrm{O}$ comentário funciona também no nível metatextual, na antecipação da crítica ao romance de estreia do próprio Barreto. O satirista toma o espaço do personagem-narrador nesses momentos de cruzamento entre a situação romanesca e a situação do romance no seu meio literário. 
uma carta e, ao descer as escadas para cumprir a ordem, ouve o diretor dizendo: “- Esses f... hão de ver se valho ou não valho alguma coisa! Súcia!” (IC, 2010, p. 262).

Há então outra pausa na narrativa, semelhante à da descrição da moradia de Isaías. Nela, o narrador fala da "particular doçura" que passara o início do mês de maio ${ }^{123}$ e nos revela alguns de seus sentimentos, informando ao leitor da morte de sua mãe, que ocorrera dois meses antes. A estratégia narrativa de quebra do ritmo e mudança de foco funciona, novamente, como um postergador dos acontecimentos possibilitando ao narrador produzir um maior impacto na descrição dos dias da Revolta. Além disso, esse último adiamento vem acrescido de uma confissão do narrador, o qual, já com os sentimentos entorpecidos, de quem não sente "senão uma leve e ligeira dor" com a recente morte da mãe e observa a perda definitiva de suas ambições da juventude, "sem desgosto", lembrando-se das antigas aspirações, "como impressões de uma festa a que fora e a que não devia voltar mais" (p. 263). Depois dessa digressão, o narrador finalmente conta o que se passara no curso da Revolta, desde a primeira percepção do "espírito popular" que tinha observado na sua casa até a constatação de que a crença na suposta operação dos pés grandes é que tinha levado ao motim ${ }^{124}$ :

"Recolhi-me cedo nessa noite e dormi profundamente durante toda ela. Não vi a destruição dos combustores de iluminação, que os populares tinham levado a efeito. Só notei de manhã, já pelas oito horas, descendo a ladeira. [...] A fisionomia das ruas era de expectativa. As patrulhas subiam e desciam; nas janelas havia muita gente espiando e esperando qualquer coisa. Tínhamos deixado a estação do Mangue, quando de todos os lados, das esquinas, das portas e do próprio bonde partiram gritos: 'Vira! Vira! Salta! Salta! Queima! Queima!'.

O cocheiro parou. Os passageiros saltaram. Num momento o bonde estava cercado por um grande magote de populares à frente do qual se movia um bando multicor de moleques, espécie de poeira humana que os motins levantam alto e dão heroicidade. Num ápice, o veículo foi

123 A Revolta da Vacina se passou entre os dias 11 e 15 de novembro de 1904. O fator deflagrador foi, segundo Sevcenko, a publicação do plano de regulamentação da aplicação da vacina obrigatória contra a varíola no dia nove de novembro. Em meio a um fortíssimo surto de varíola na capital e, incitados pelos líderes da Liga contra a Vacina Obrigatória, a enorme multidão que enchia a praça no largo de São Francisco de Paula inicia o motim. Isso acontece em meio a uma tentativa de golpe militar originalmente prevista para ocorrer em quinze de novembro. Usando de todas as forças policiais disponíveis, até mesmo a Guarda Nacional, tanto a Revolta como o Golpe sucumbiram e no dia 16, o governo revoga a obrigatoriedade da vacina. Ver Sevcenko (2010). As datas do romance não condizem com os acontecimentos da Revolta da Vacina, ainda assim, as situações narradas guardam estreitas semelhanças.

${ }^{124}$ José Murilo de Carvalho lembra que a o oposição à vacina apresentou "aspectos moralistas". Segundo Carvalho, apesar de ser aplicada no braço, espalhou-se a notícia "de que os médicos do governo visitariam as famílias para aplicá-la nas coxas, ou mesmo nas nádegas das mulheres e filhas dos operários" (Carvalho, 2009, p. 75). 
retirado das linhas, untado de querosene e ardeu. Continuei a pé. Pelo caminho a mesma atmosfera de terror e expectativa. Uma força de cavalaria de polícia, de sabre desembainhado, corria em direção ao bonde incendiado. Logo que ela se afastou um pouco, de um grupo partiu uma tremenda assuada. Os assobios eram estridentes e longos; havia muito da força e da fraqueza do populacho naquela ingênua arma. E por todo o caminho, este cenário se repetia.

Uma força passava, era vaiada; se carregava sobre o povo, este dispersava-se, fragmentava-se, pulverizava-se, ficando um ou outro a receber lambadas num canto ou num portal fechado. O largo de São Francisco era mesmo uma praça de guerra. Por detrás da Escola Politécnica, havia uma força e os toques da ordenança sucediam-se conforme as regras e preceitos militares. Parei. Um oficial a cavalo percorria a praça, intimando o povo a retirar-se. Obedeci e, antes de entrar na rua do Ouvidor, a cavalaria, com os grandes sabres reluzindo ao sol, varria o largo com estrépito. Os curiosos encostavam-se às portas das casas fechadas, mas aí mesmo os soldados iam surrá-los com vontade e sem pena. Era o motim.

As vociferações da minha gazeta tinham produzido o necessário resultado. Aquele repetir diário em longos artigos solenes de que o governo era desonesto e desejava oprimir o povo, que aquele projeto visava enriquecer um sindicato de fabricantes de calçado, que atentava contra a liberdade individual, que se devia correr a chicote tais administradores, tudo isso tinha-se encrostado nos espíritos.

Durante três dias a agitação manteve-se. Iluminação quase não havia. $\mathrm{Na}$ rua do Ouvidor armavam-se barricadas, cobria-se o pavimento de rolhas para impedir as cargas de cavalaria. As forças eram recebidas a bala e respondiam. Plínio de Andrade, com quem há muito não me encontrava, veio a morrer num desses combates. Da sacada do jornal, eu pude ver os amotinados. Havia a poeira de garotos e moleques; havia o vagabundo, o desordeiro profissional, o pequeno-burguês, empregado, caixeiro e estudante; havia emissários de políticos descontentes." (IC, 2010, p. 264-265)

O primeiro aspecto dessa descrição é que ela é feita de um ponto de vista interno, desde a noite de Isaías até seu percurso rumo ao jornal, para um ponto de vista externo: "da sacada do jornal". Outro elemento estruturante no trecho é a oscilação entre a descrição dos eventos e os comentários do narrador como a interpretação do "bando multicor de moleques", uma "espécie de poeira humana que os motins levantam alto e dão heroicidade"; ou da subjetiva atmosfera de terror e expectativa; ou ainda do assobio como "ingênua arma" do populacho.

Outro aspecto central é a utilização de frases curtas, com a descrição de ações rápidas, como "O cocheiro parou”, "Os passageiros saltaram”, "Uma força passava, era vaiada", "Era o motim", para acelerar o ritmo da descrição, acompanhando o frenesi dos acontecimentos - muito diferente do ritmo desacelerado da descrição do cortiço ou da intimidade do narrador-personagem. A linguagem é entrecortada, parecendo seguir o 
ritmo dos eventos: "uma força passava, era vaiada; se carregava sobre o povo, este dispersava-se, fragmentava-se, pulverizava-se...". Mas, esse ritmo só se mantém enquanto o narrador se encontra no centro dos acontecimentos.

Já no último parágrafo, o que se vê é a capacidade sintética para descrever os três dias de agitação: a ausência de iluminação, as barricadas na rua do Ouvidor, a morte de Plínio de Andrade ${ }^{125}$. Mas, agora, Isaías observa tudo isso "da sacada do jornal”, de onde ele vê, distanciado, os personagens dessa cena: o vagabundo, o desordeiro profissional, o pequeno-burguês, o empregado, o caixeiro e o estudante, além dos emissários de políticos descontentes. Trata-se de uma mudança de perspectiva, sendo que o narrador vê agora a cena como um quadro, não mais situado no centro dela. Desaparecem também as frases em primeira pessoa: "tínhamos deixado a estação do Mangue", ou "Parei", "Obedeci”, para dar lugar a uma descrição mais neutra dos acontecimentos. Assim como desaparecem a oscilação das escolhas lexicais de entre o coloquial e o poético, esse último no "bando multicor de moleques", na "ingênua arma".

A interpretação mais imediata dos acontecimentos aparece no penúltimo parágrafo do trecho citado acima, no qual o narrador interpreta a origem do motim: as vociferações do jornal tinham produzido o "necessário resultado". O repetir diário dos ataques ao governo que "desejava oprimir o povo", ou que o projeto tinha como meta "enriquecer um sindicato de fabricantes de calçado", tudo isso que vinha sendo divulgado pela gazeta "tinha-se encrostado nos espíritos". Os boatos da cirurgia nos pés juntamente com a incitação dos jornais teriam provocado os motins. Essa "fábrica de carapetões" funcionara como uma máquina de guerra para a qual o estímulo seria somente o aumento das vendas, "tinha aumentado cinco mil exemplares", mas que não media as consequências desse estímulo para a população. A lisonja à multidão não leva em conta o sofrimento da mesma. As mortes são encobertas, pois "não queriam abater a coragem do povo com a imagem aterradora da morte" (IC, 2010, p. 267).

As "refregas sangrentas" que aumentavam as vendas e o encobrimento das mortes são, de fato, muito semelhantes aos acontecimentos da Revolta da Vacina. Segundo Sevcenko (2010), nunca se contaram os mortos da Revolta da Vacina, pois muitos foram morrer longe do "palco dos acontecimentos". O que se lê na acusação do narrador é a relação criminosa entre imprensa sensacionalista e o motim, a mesma

${ }^{125}$ Se realmente Plínio de Andrade era a versão romanesca do autor, essa morte simbolizaria a última das resistências, o fím de qualquer projeto utópico possível para o personagem. 
imprensa que encobrira o início da questão com a notícia de um “crime sensacional".

Da janela do jornal, depois do "torneio" entre a polícia e os populares, o narrador presencia a morte do "pequeno italiano na esquina" que vendia os jornais da tarde. Este personagem será o mártir da revolta, já que morre num momento de calmaria quando "a rua parecia retomar sua vida normal" (IC, 2010, p. 267). O italianinho foi derrubado e morto pelos cavalos, "como se fosse um bocado de lama". Ele foi levado já morto pelos populares para o escritório do jornal e o narrador, ao finalizar o capítulo, recorda-se da frase proferida por Loberant no início da narrativa dos eventos: “- Esses f... hão de ver se valho ou não valho alguma coisa! Súcia!” (p. 268). Ao criar um ciclo que começa e termina com a frase do jornalista, a interpretação da Revolta pelo narrador sugere que ela não passa de mais uma história sensacionalista do jornal, uma ficção. E a única morte noticiada só dá ensejo a mais um jogo sensacionalista, com a criação de um mártir. A partir desse momento do romance, inclusive, com o encaminhamento rumo ao fim, o tom se torna melancólico, com o suicídio de Floc, o desencanto do narrador, a saída de alguns jornalistas para o serviço público e a entrada de Isaías para a função de repórter. E nas últimas palavras do romance, Isaías olha para o "céu muito negro", desgostoso de si por "ter consentido em ser um vulgar assecla e apaniguado de um outro qualquer". (p. 302).

Essa imagem da natureza, de fato, perpassa todo o romance. O céu e as nuvens são como metáforas da transformação do personagem. Da delegacia, quando é chamado para depor sobre um roubo no hotel onde residira nos primeiros tempos da vida na capital, ele olha pela janela e vê uma "nesga do céu" em meio às "nuvens pardacentas" que o acompanharam no caminho até ali. Depois do depoimento do "mulatinho", porém, as "nuvens plúmbeas já de todo tinham coberto a nesga do céu vista pela janela" (p. 129). Ao final do livro, antes de entrar em casa, Isaías olha para o céu negro e estrelado, "esquecido de que a nossa humanidade já não sabe ler nos astros os destinos e os acontecimentos" (p. 302), frase que vimos nas notas sobre o romance.

Há uma relação entre a descrição da natureza e o destino da humanidade muito diferente de outros romances da época com viés utópico, mas sem a problematização que a obra de Barreto nos oferece. Como vimos em O Ideólogo (1903), do anarquista Fábio Luz, ao final do romance, o narrador descreve o céu que antecipa o futuro grandioso do personagem central, Anselmo: "Por sobre as nuvens escuras que cobriam já o céu, os raios do sol no declínio do dia se refrataram na água em suspensão, e um 
formoso arco-iris se desenhou vivaz na curva do firmamento." (Luz, 1903, p. 222). A natureza aparece aqui como força que indica o "bom augúrio", o sinal "do amor, da prole, o amor da família e da humanidade". A natureza funciona como um sinal de tempos felizes vindouros, representa a confiança no futuro e na transformação. Também em Regeneração (1904), de Curvelo de Mendonça, a natureza funciona com força positiva. Ao voltar à Jerusalém, no falanstério organizado por Antonio e destruído pelo uso capitalista e degradador da produção agrícola, a tempestade inicia o trabalho da regeneração da terra: "Dir-se-ia que a natureza pretendera varrer daquela região a poeira das paixões inferiores que a tinham devastado." (Mendonça, 1904, p. 150).

Antonio Candido, no texto Radicais de Ocasião, critica esse "pendor socialista mais humanitário do que político" (Candido, 2007, p. 79) entre os intelectuais do início do século XX, um "radicalismo verbal" oposto do "compromisso militante". Dentre os representantes desse anarquismo humanitário de "corte tolstoiano", Candido inclui nomes como Elísio de Carvalho, Curvelo de Mendonça e Fábio Luz. A relação com a natureza nos casos de Mendonça e Luz corrobora a tese do radicalismo verbal de Candido. No caso de Barreto, e particularmente do narrador Isaías, a relação com a natureza aparece como um traço impressionista de uma vida desumanizada, um breve flagrante de um estado de alma em crescente desarmonia com o futuro almejado. A natureza em Barreto está muito mais atrelada à vida real do homem na cidade do que a uma utopia comunitária propagada pelos "radicais de ocasião".

Mesmo no intuito de fornecer uma ligação para o mútuo entendimento dos homens, a arte limabarretiana se opõe ao radicalismo verbal, mas não se furta ao compromisso militante. Para este fim, o local de enunciação da obra transita do jornalístico ao literário com uma liberdade anatoliana. No trecho que transcrevemos sobre a revolta da vacina, esse trânsito aparece não somente no percurso do narradorpersonagem, mas também nas diferentes formas de escrita, do interior ao exterior, do pessoal ao formal, do lento ao rápido. As ferramentas da escrita diária: a denúncia do poder, o sensacionalismo, a linguagem clara, são parte fundamental da literatura militante que Barreto lê em Anatole France. Essa literatura é, em grande medida, fruto da pena destes cronistas.

Enfim, as questões (do Mississipi e dos sapatos obrigatórios) colocam em cena dois pontos de vista narrativos, a do personagem-narrador e a do comentador-satirista, dois mundos paralelos, o ficcional e o real, e, num plano extradiegético, dois universos, 
o do autor e da sua origem (hors et là). Ao trazerem para o centro da narrativa questões de grande impacto na vida social e política de seus países, ambos os autores revelam o jogo que se dá entre os grupos políticos locais e a vida das pessoas comuns, tornando a grande História parte da pequena história ficcional de seus personagens. 


\section{O Poético}

Vimos traçando até aqui alguns elementos no intuito de delimitar o que seria a literatura militante de Lima Barreto, cuja matriz viria da obra de Anatole France. Primeiramente, vimos que a leitura limabarretiana transgride a interpretação corrente do escritor sensualista em solo brasileiro, contrapondo-se a seus pares na sua leitura errática. Apontamos também para o surgimento de um tipo de herói, o herói intelectual, como protagonista de romances nos quais a experiência cede espaço para a reflexão, elevando a palavra à condição de arma de batalha na denúncia das mazelas humanas. Neste processo, os recursos jornalísticos provenientes da escrita diária nos jornais e revistas se revelaram fundamentais.

Diante desta progressiva redução do espaço de ação do personagem, observamos um processo de caricaturização do outro que irá, como veremos, se radicalizar como satirização. Porém, este capítulo se configura como um respiro neste processo. Destacaremos aqui o lado não caricatural, dando ênfase à poesia flagrante da relação entre o personagem e sua cidade. Isto porque, no caso de dois personagens, Gonzaga de Sá (e Augusto Machado) e o senhor Bergeret, o embate entre o indivíduo e a realidade hostil nos guiou em outra direção. O percurso peripatético destes personagens que percorrem a cidade introjetando-a no discurso narrativo inspirou-nos um outro olhar que já aparece, de certa maneira, na reflexão sobre a "poética" destes irmãos literários.

Como já sugeriram Tristão de Ataíde e Robert Oakley, são tangíveis as semelhanças entre os romances da série Histoire Contemporaine e o J. Gonzaga de Sá. Seus heróis intelectuais percorrem a cidade, refletindo sobre os mais variados assuntos da vida política, social e mesmo existencial. Não há dúvida, para nós, de que a aproximação é correta; Bergeret e Gonzaga guardam uma proximidade nos seus percursos. Porém, ao mesmo tempo em que a aproximação é clara, as pequenas sutilezas de distinção se tornam mais relevantes. Nesse capítulo, buscaremos tratar desse jogo complexo entre semelhanças e diferenças que se constroem nas relações particulares entre esses dois personagens e seus respectivos ambientes. 
Gonzaga de Sá foi publicado em 1919, mas já estava pronto no mesmo ano da publicação do romance de estreia, Isaías Caminha, em 1909. Segundo Barbosa (1959; 2012), os dois romances nascem do "mesmo ressentimento", da sensação de revolta e inconformismo diante das injustiças que o autor Lima Barreto vinha sofrendo. $O$ “cerebrino" Gonzaga de Sá, porém, se diferencia em alguns aspectos do "brutal” Isaías Caminha ${ }^{126}$.

Primeiramente, a obra acompanha o autor durante anos, desde as notas de 1906, data da Explicação Necessária, até o ano da publicação. Em abril de 1918, Lima Barreto escreve a Advertência, na qual atribui a Augusto Machado a autoria da obra que transita entre a biografia e o romance ${ }^{127}$. Em abril do mesmo ano, Barreto escreve ao amigo Antônio Noronha Santos, informando-o de que, estando "sem roupa de lã para sair" (CAPI, 1956, p. 109), aproveitava a ocasião para rever o romance. Em segundo lugar, o "percurso do livro" é marcado por duas internações do autor: a primeira no Hospital Nacional de Alienados, entre agosto e outubro de 1914 e a segunda, no Hospital Central do Exército, após uma “crise de alucinação alcoólica” (Barbosa, 1959, p. 281), entre novembro de 1918 e janeiro 1919. Foi durante essa última internação que Barreto assinou um contrato com Monteiro Lobato para a publicação de Gonzaga de Sá. Revisado, trabalhado, com contrato de publicação e com recepção bem mais calorosa que Isaías e Policarpo ${ }^{128}$, este romance foi, certamente, o mais bem acabado romance de Lima Barreto.

Do outro lado do Atlântico, alguns anos antes da virada do século XX, Anatole France publicava os primeiros artigos de "Nouvelles Ecclésiastiques", no jornal L'Écho de Paris. Esses artigos coletados posteriormente em volume, tornar-se-iam a série Histoire Contemporaine. Nos dois primeiros romances da série, L'Orme du Mail (OM) e Le Manequin d'osier (MO) ${ }^{129}$, France concentra sua crítica à França do ralliement $^{130}$,

\footnotetext{
${ }^{126}$ No caso do romance de estreia, comentamos que o narrador se divide entre personagem e comentador. Em Gonzaga de Sá, é Augusto Machado quem conta a história de Gonzaga, mas sua própria história se sobrepõe em muitos momentos à do biografado.

${ }^{127}$ Augusto Machado cita ironicamente como modelos de biografia o burocrata Pelino Guedes e Plutarco, ao mesmo tempo em que diz se ater "aos azares da publicação de um opúsculo aliterado" (GS, 1956, p. 31).

${ }^{128}$ As cartas trocadas com o editor Monteiro Lobato nos revelam a constante comunicação entre autor e editor acerca de prazos, valores e recepção da obra. Ver volume XVII das obras completas.

${ }^{129} \mathrm{O}$ romance L'Orme du Mail foi traduzido no Brasil como À sombra do Olmo. Consultamos uma edição recente, de 2009, da BestBolso, de 2009, com tradução de João Guilherme Linke. A obra seria melhor traduzida como "Alameda dos Olmos", espaço central do romance para onde Bergeret vai para refletir a sós ou acompanhado do abade Lantaigne. Com exceção do capítulo XIV, publicado na
} 
colocando em cena dois religiosos, o erudito Lantaigne e o oportunista Guitrel, que disputam uma vaga para o bispado de Tourcoing. Ainda influenciado pelas repercussões da "querelle du Disciple", France também responde nesses primeiros dois volumes a um artigo de Brunetière, de 1895, no qual, depois de uma visita ao papa Léon XIII, no Vaticano, o editor da Revue des Deux Mondes recusa o papel da ciência em prol da religião. O anticlericalismo de France aparece no "effet Brunetière", segundo Bancquart, ecoando principalmente nos primeiros capítulo de L'Orme. France escreve, do lado político, contra a França do ralliement e, do clerical, contra a França crente e mística $^{131}$.

O primeiro volume da série, narrado em terceira pessoa, trata da rivalidade entre os dois religiosos, entremeada pela construção de um quadro de apoios e oposições políticas. Lantaigne tem o apoio de Cassignol, "premier président"132, do general Chartier de Chalmot e do seu amigo, o abade e ex-capelão militar Lelond, além do advogado Leronde. Guitrel, por outro lado, conta com o apoio do prefeito WormsClavelin e de sua esposa, ambos de origem israelita. Nesse jogo de poder, o narrador enfatiza ironicamente a luta pelo espaço político travada entre a nova burguesia de origem judaica e a antiga aristocracia católica e monarquista. A burguesia judaica, ao entrar no jogo político, busca atrair parte desse grupo tradicionalista por meio da figura de Guitrel e o narrador não deixa de ironizar o israelita Worms-Clavelin que "sentait confusément que, près de cet ecclésiastique de souche paysanne [...] il se francisait luimême, se naturalisait ....” (OM, 1987, p. 736). Essa é a França do apaziguamento sobre a qual o criador de Coignard deposita suas verrinas.

Todos esses personagens e intrigas, principalmente Guitrel, serão nos dois primeiros volumes entremeados pelos passeios do senhor Bergeret e Lantaigne na Alameda dos Olmos, pelas discussões na livraria do sr. Paillot e pelas histórias da profetisa Deniseau. As digressões e debates cortam o impulso dramático das intrigas

Revue de Paris, os outros capítulos saíram na Écho de Paris. A obra foi publicada em volume em janeiro de 1897. O romance Le Mannequin d'osier foi traduzido como O Manequim de Vime. Também consultamos a edição de 2009 da BestBolso. Na França, a obra é publicada no mesmo ano que L'Orme, em 1897.

${ }^{130}$ Ver a primeira parte do capítulo anterior.

${ }^{131}$ A figura da profetisa Claude Deniseau aparece no primeiro livro da série atraindo um grande número de curiosos que aguardava ansiosamente pelas revelações da jovem. Esse tipo de fenômeno religioso foi tratado também por Zola, no romance Lourdes, primeiro volume da série Les Trois Villes, em 1894.

${ }^{132} \mathrm{O}$ cargo corresponde à presidência da Cour des comptes (Tribunal de Contas), um jurisdição encarregada, como no Brasil, de controlar as contas públicas. 
religiosas, assim como contiveram a ação dos heróis intelectuais Servien e Isaías. Em Le Mannequin, o narrador acrescenta um outro espaço para os acontecimentos: a residência dos Bergeret, principalmente depois que o professor flagra a sua esposa com o seu discípulo numa "attitude violente qui tenait de l'amour et de la lutte"133.

A intriga mais movimentada de Le Mannequin não modifica, porém, a lógica digressiva da narrativa. $\mathrm{O}$ impulso dramático não se realiza e não há um encadeamento de ações a partir deste acontecimento que dê movimento à trama do romance. $\mathrm{O}$ sr. Bergeret não se dirige à esposa depois do flagrante de traição e ela, exaurida com o desdém, acaba voltando para a casa dos pais ao final do livro. Nada se altera na vida de Bergeret durante os três primeiros livros, somente no último a mudança para Paris promete novas situações. Porém, a força dramática da ação é novamente anulada em prol das discussões e reflexões do herói intelectual Bergeret, personagem cuja centralidade vai se consolidando no decorrer dos livros, principalmente nos dois últimos romances.

O terceiro volume, L'Anneau d'Améthyste ${ }^{134}$ (AA), é, segundo Bancquart, "le témoignage de l'affaire Dreyfus vécue à chaud"' (Bancquart, 1991, p. 1113). Os textos reunidos em L'Anneau ainda foram publicados no jornal antidreyfusard L'Écho de Paris, que durante os acontecimentos do caso Dreyfus, torna-se o órgão oficial da Liga da Pátria Francesa, resposta conservadora à fundação da Ligue pour la défense des droits de l'homme, de 1898, apoiada por France. Apesar da situação incômoda de France no periódico, como quando o major Esterhazy ${ }^{135}$, ao ser inocentado em 1898, agradece o apoio do jornal, France não hesita em traçar do major um "portrait peu flatteur" sob o nome de Raoul Marcien. Nas páginas do L'Écho, enquanto o personagem de M. Bergeret ataca os que estão contra a revisão do processo Dreyfus, o editorialista Pertinaux, denuncia o sindicato Dreyfus ${ }^{136}$. No quadro do jornal, Bancquart ressalta o “exemple tout à fait paradoxal de discordance politique entre l'esprit d'un journal et

${ }^{133}$ No conto "Uma noite no Lírico", publicado na coletânea Histórias e Sonhos, num diálogo entre o personagem principal Frederico Bastos e o amigo, o zombador Juvenal, no Lírico, o satirista faz uma espécie de radiografia da sociedade presente e ao apontar para uma moça, afirma: “- É a fillha do Dr. Silva a quem, certo dia, encontraram, em uma festa campestre, naquela atitude que Anatole France, num dos Bergerets, diz ter alguma cousa de luta e de amor ..." (Barreto, 2008: 139).

${ }^{134}$ Os capítulos que compõe L'Anneau d'améthyste saem no Écho de Paris, de setembro de 1897 a dezembro de 1898, precedidos do título geral Histoire Contemporaine. A obra em volume foi publicada pela Calmann-Lévy em fevereiro de 1899 com uma edição corrigida pelo autor em 1924. O romance foi traduzido como $O$ anel de ametista, consultamos a edição de 2009 da BestBolso.

${ }^{135}$ Esterhazy é o verdadeiro responsável pelos crimes atribuídos a Dreyfus.

${ }^{136}$ Uma das formas pejorativas de tratamento dos dreyfusards por seus opositores. 
celui de son principal feuilleton, publié à la une toutes les semaines" (Bancquart, 1991, p. 1142). A constância crítica de France só ressalta a sua independência.

Em L'Anneau, logo nos primeiros trechos do romance, o narrador trata de dois grupos da aristocracia, dois châteaux: o dos aristocratas antissemitas Brécés e o de madame de Bonmont, viúva, judia, convertida ao catolicismo e amante de Raoul Marcien. A situação dos dois grupos se equilibra graças à influência de Guitrel. Até a viúva do israelita se torna antissemita. Segundo o narrador, Raoul “... avait toujours été antisémite, Rara $^{137 \text {, }}$ (AA, 1991, p. 47), enquanto a senhora de Bonmont passa a sê-lo desde então. Depois de retratar o quadro de polaridades entre a burguesia israelita convertida e a antiga aristocracia dos dois primeiros volumes, temos em L'Anneau, a integração desses dois mundos com Guitrel, responsável pelo contato entre os castelos da tradição e do dinheiro. A volubilidade ideológica de seus retratados, a aristocracia que aceita os inimigos pelo poder do dinheiro e os burgueses que se convertem para adquirir projeção política, contrastam com a figura de Bergeret, que, caminhando pela alameda dos Olmos, mantém-se constante em suas atribuições reflexivas e provocadoras, não mais no estilo bonhachão de Coignard, mas de uma forma mais sóbria.

Não é somente a essa oposição à constância do herói intelectual que o narrador recorre para denunciar a relação imoral entre dinheiro e poder. Ele se utiliza de recursos oratórios como a repetição dos argumentos para denunciar a fragilidade de raciocínio dos antidreyfusards. No castelo do duque de Brécé, onde se encontram o general Cartier de Chalmot, o abade Guitrel e o advogado sr. Lerond, o anfitrião é o primeiro a se referir a um mote de defesa dos antidreyfusards: “... il n'est pas admissible que sept officiers français se soient trompés". À concordância de Guitrel, segue-se o comentário de Lerond, "une erreur judiciaire est la chose la plus invraisemblable". E, mais à frente o duque repete: "D'ailleurs, peut-on admettre que sept officiers français se soient trompés?" (AA, 1991, p. 11). Também no castelo de madame de Bonmont, o sr. de Terremondre, repete o argumento sem, porém, completá-lo, o que já é passível de ser realizado pelo próprio leitor: "Et il me semble que quand sept officiers ..." (p. 51). A opinião se efetiva na aquiescência de Guitrel, o elo de ligação entre os dois ambientes ironizados pelo narrador.

\footnotetext{
${ }^{137}$ Trata-se do apelido carinhoso da senhora de Bonmont ao personagem Raoul.
} 
Segundo Bancquart, essa operação de denúncia pela linguagem, a repetição, a denúncia das incoerências ou as mudanças abruptas dos personagens refletem, na percepção do autor, os próprios procedimentos do caso Dreyfus, o processo à huis-clos, os documentos secretos, os segredos de justiça. Já que nada se sabe, tudo pode ser verdade. E a repetição é uma ferramenta dessa afirmação do falso que se torna verdadeiro. Inclusive, segundo a crítica, essa denúncia do falso não aparece somente nesse período da vida do autor, “... il (France) a travaillé pour ainsi dire toute sa vie sur 'le faux': faux en fabrication littéraire, faux en réputation historique." (Bancquart, 1991, p. 1136).

Como já vimos, a denúncia do falso em Barreto o direciona para o nível caricatural na representação, como observamos a partir dos personagens de Isaías Caminha. No caso de Gonzaga de Sá, porém, essa denúncia é mais sutil. Em parte, pelo lirismo da linguagem utilizada pelo narrador, que pode ser resultado de um melhor acabamento da obra, o que o aproxima mais da estética anatoliana. Na suavização da crítica, essa filiação se consolida, enquanto a lógica da denúncia permanece nas entrelinhas, inclusive na caricaturização de alguns personagens. Mas é principalmente nas imagens do espaço criadas pelo narrador que vemos as semelhanças entre as duas obras. Seja na Alameda dos Olmos, em Paris ou no Rio de Janeiro, o quadro impressionista $^{138}$ das paisagens nos parece traduzir um pouco da interioridade dos personagens, porém, no contexto da obra, essa interioridade cede cada vez mais espaço para a crítica e a sátira.

\section{"Le jardin secret"}

Em Isaías Caminha, observamos anteriormente como a imagem da natureza atravessa o romance. A alusão ao céu e às nuvens funciona ali como uma metáfora da transformação do personagem. Essa presença da natureza como elemento de composição do personagem também ocor no passeio entre os Olmos, desde o primeiro volume da série Histoire Contemporaine. A Alameda dos Olmos é uma espécie de refúgio intelectual do senhor Bergeret. Esse cenário de reflexão aparece pela primeira vez no capítulo sete de L'Orme, quando o abade Lantaigne encontra ali o sr. Bergeret, esse "esprit distingué, mais bizarre", com o qual o religioso, que "pardonnait son

\footnotetext{
${ }^{138}$ Em artigo sobre Triste fim de Policarpo Quaresma, Fabio Luz tratou da ironia de Barreto e também das descrições impressionistas dos ambientes: "como pintor impressionista dá seis, oito ou mais pinceladas de tintas diversas" (PS, 2006, p. 39).
} 
scepticisme", se permitia conversar quando a alameda estava deserta. O misantropo professor Bergeret vaga por esse cenário inspirador, frustrado em suas ambições, vivendo um casamento infeliz e monótono, permitindo-se, porém, estar nesse espaço "à sa guise" (OM, 1987, p. 759). A alameda é o seu "jardin secret"139, onde o personagem, destacado da realidade enfadonha, aguça seu raciocínio e sua crítica. Assim como o céu de Isaías acompanhava o caminho do personagem, também o narrador anatoliano relaciona, em Le Manequin, a imagem do céu com o sentimento do personagem:

“...gagné par l'aménité de l'air et du jour, M. Bergeret s'assit au bord du chemin [...]. Il voyait à travers les membrures fines des arbres le ciel lilas taché de fumées et goûtait une paisible tristesse à mener ainsi ses songeries dans la solitude." (MO, 1987, p. 892).

Não se trata aqui da mesma situação conflituosa que a metáfora da natureza nos colocou em Isaías Caminha, porém o elo entre a alameda dos olmos e o personagem nos sugere uma equivalência entre o sentimento do personagem e o espaço físico. $\mathrm{O}$ espaço funciona nos primeiros romances da série do senhor Bergeret como refúgio. Essa unidade, porém, se modificará um pouco no último volume da série, M. Bergeret à Paris, com a incorporação do espaço como escrita da História, que se dará com a integração da cidade de Paris à história do personagem. Na comparação entre a posição do personagem diante da natureza, a imagem do céu para o personagem Isaías acompanha-o como uma metáfora da sua transformação no romance, enquanto nos primeiros romances da série Histoire, o mesmo quadro estabelece com o senhor Bergeret uma relação de segurança, de abrigo do mundo hostil. Ou seja, enquanto a natureza põe em movimento a trajetória de Isaías Caminha, no caso do professor Bergeret ela desloca o personagem do espaço da ação.

A natureza e o indivíduo em Gonzaga de Sá também travam um tipo de simbiose. Os dois amanuenses Gonzaga e o narrador Augusto Machado ${ }^{140}$ vão ao Passeio Público "para ver certo matiz verde que o céu toma, às vezes, ao entardecer" (GS, 1956, p. 38) e quando a "tarde dúbia, de luz irregular" ameaça uma tempestade, a secreta correspondência de Gonzaga com o meio avisa ao narrador Machado "que não choveria". Nessa fusão do personagem com a natureza, em que o homem antecipa seus sinais, a relação vai se tornando cada vez mais integrada; a cidade passa, então, de

\footnotetext{
${ }^{139}$ A expressão "jardin secret” diz respeito aos sentimentos e pensamentos mais íntimos de um indivíduo.

${ }^{140}$ Para Osman Lins, Gonzaga e Machado são como "uma sonata para dois movimentos afins" (Lins, 1976, p. 44).
} 
espaço de refúgio a personagem e a natureza se humaniza. Vê-se então a "gabada Avenida 'Beira-Mar'”, "a calma face da Guanabara, ligeiramente crispada" que mantém um "certo sorriso simpático", enquanto entabula uma conversa "com a grave austeridade das serras graníticas". O "sorriso complacente do gôlfo" com sua "segurança divina”, ou a Glória, "com o seu séqüito de palmeiras pensativas”, são todos elementos desse quadro vivo da natureza que engendram um hino de amor à cidade.

Um hino de amor à cidade cantado pelo poeta: "O poeta tinha razão: era verdadeiramente a grandiosa Guanabara que eu via!" (GS, 1956, p. 39). O lirismo dos trechos em que a natureza toma o papel central da narrativa é o elemento que reintroduz a interioridade do personagem, diante da "mágoa insondável do mar" ou na "tristeza da Boa Viagem". Como Bergeret na alameda dos olmos, a natureza se junta ao personagem como abrigo contra um mundo hostil, um espaço de reflexão. Não se trata mais de um espelho do conflito como no caso de Isaías, mas de uma interpenetração de espaço e personagem: a Glória, "com o seu séqüito de palmeiras pensativas", desperta as reflexões de Machado. A paisagem o faz pensar e rememorar sua vida, observando até onde seu desenvolvimento tinha se realizado. O destino almejado, "conforme o voto que os meus exprimiram no meu batismo", parece-lhe inalcançável, já que "se ainda não estou, nem a milésimo do caminho, nunca mais lá chegarei”.

A fusão inicial entre personagem e natureza dá lugar à humanização do espaço com a introdução da cidade como elemento poético, mas a natureza também inspira reflexões no personagem. Num segundo momento, porém, esta relação passa também a ser configurada como escrita da história do personagem e da grande História. E neste caminho de incorporação de novos elementos, a relação entre o indivíduo e a natureza passa de harmoniosa a conflituosa. Não se trata mais somente de um eu com a natureza. As reflexões despertadas no refúgio da natureza levam às dissonâncias entre o eu e o "ambiente pátrio". Essas dissonâncias vão ganhando texturas mais agressivas e a harmonia inicial é temporariamente rompida.

Na serra dos Órgãos, onde Machado aprendera "a desprezar as fôfas cousas da gente de consideração e a não ver senão a grandeza de suas inabaláveis agulhas que esmagam a todos nós", acompanhamos o movimento de resignação do narrador diante das injustiças sofridas não só por ele, como por todas as vítimas da sociedade. Ele foi bom e tolerante "como o mar da Guanabara", e sob o "sol causticante" do verão que lhe ensinou a "sofrer com resignação" e a se "curvar aos ditames das cousas". A narrativa 
segue num crescendo de intensidade e revolta até que saturado daquela "melancolia tangível, que é o sentimento primordial da minha cidade", o narrador conclui sobre a cidade amada: "Vivo nela e ela vive em mim!" (GS, 1956, p. 40). Enquanto o movimento de harmonia e desarmonia vivido por Isaías levara o narrador a optar pelo tom caricatural, nesse romance, a fusão do personagem com o espaço carregado da história da vida de Machado e Gonzaga e da História dos homens em geral se converte em poesia e melancolia.

Num movimento de expansão, já com a cidade internalizada, o narrador amplia as relações do espaço para a História, verificando "nada ter perdido das aquisições de meus avós, desde que se desprenderam de Portugal e da África”. A sua história e a dos seus antepassados aparecem inscritas na cidade, a "longa elegia das dores que ela presenciou nos segmentos de vida que precederam e deram origem à minha". No correr dessa descrição, a influência externa é alvo de crítica com a indignação do narrador com o "bando de inglêses" que passa carregando ramos de arbustos: "Tive ímpetos de exclamar: doidos! Pensam que levam o tumulto luxuriante da minha mata, nessa folhagem de jardim!” (p. 41). O ímpeto patriótico, porém, é logo suavizado pela lembrança de seus autores queridos, "de Taine, de Renan, de M.Barrès, de France, de Swift, e Flaubert”.

Nesse contato poético entre o eu e o mundo, as relações entre o personagem e seu meio voltam a ser interrompidas pela pena do narrador que, nas suas digressões e reflexões, inibe a tomada da narrativa pela ação ou pela emotividade. Uma interrupção mais abrupta do narrador acontece no anúncio da morte de Gonzaga de Sá. Augusto Machado diz simplesmente que Gonzaga "abaixou-se para colhêr uma flor que me oferecera, mas caiu, e morreu. Foi assim." (p. 43). Assim como a subjetividade escondida da morte da mãe de Isaías, a dor parece transferir-se para a indignação, que, no caso de Gonzaga de Sá, deixa-se revelar nesta simbiose com o espaço.

A visão do céu também leva o narrador anatoliano a refletir sobre o mundo dos homens. Em Le Manequin, no primeiro dia do ano, Bergeret em suas divagações afirma: "Il me semble bien que ce qu'on appelle le monde est comme le nuage d'or et d'argent suspendu dans l'azur du ciel. Quand on le traverse, on ne voit plus qu'un brouillard." (MO, 1987, p. 897). Segundo Bancquart, esta frase aparece no começo de um artigo de 
France $^{141}$ no qual ele fala da literatura mundana: "Toute littérature dite mondaine est une littérature superficielle [...]. Elle n'atteint pas l'homme même et s'arrète aux dehors. De là sa fadeur et sa tristesse" (Bancquart, 1987, p. 1390). Por trás do lamento de Bergeret, vê-se uma crítica a um tipo de literatura, dita mundana. Vejamos como Bergeret continua a sua divagação para entender melhor o que é este mundano ao qual o narrador (e o autor) se opõe:

"En réalité, les groupements sociaux sont très confus. Les hommes
s'assemblent en raison de leurs préjugés et de leurs goûts. Mais les
goûts combattent souvent les préjugés, et le hasard brouille tout. Sans
doute, une longue richesse et les loisirs qui l'accompagnent
déterminent un certain genre de vie et des habitudes particulières.
C'est là, en somme, la communauté des gens du monde. Cette
communauté se réduit à des habitudes de politesse, d'hygiène et de
sport. Il y a des façons, des dehors mondains. Il n'y a véritablement,
ce sont nos passions, nos idées, nos sentiments. Nous avons un for
intérieur dans lequel le monde n'entre pas." (MO, 1987, p. 897).

Diante desta literatura mundana que se reduz a hábitos de polidez, de higiene e de esporte, na qual só é possível ver as formas, o que está fora, a interioridade, o “jardin secret", não tem espaço. Ao se opor a este tipo de literatura, o narrador, por meio das divagações do personagem, estabelece as bases de sua própria literatura. Porém, ao atravessar a bruma que encobre o mundo, essa individualidade não encontra espaço para se expressar. A interioridade lhe parece incompatível com a existência mundana. Dentro do contexto do caso Dreyfus, é verossímil supor que o autor Anatole France se sentisse relegado entre os meios que até então frequentara.

A sensação do personagem nos parece marcada aqui por esta experiência autoral. Esta suspeita se torna mais forte, se observarmos, por exemplo, a mesma experiência da cidade e do mundo literário no romance autobiográfico Le Livre, que se traduz numa relação muito mais harmônica. Neste livro, o pequeno Pierre Nozière flana juntamente com o amigo Fontanet pelas ruas de Paris, "le plus beau lieu du monde" (Le Livre, 1984, p. 493) e a experiência do narrador que reconta sua vida ressalta ser impossível ter um espírito comum "si l'on fut élevé sur les quais de Paris ..." ao lado dos livreiros e do mundo imaginário da literatura. Este espaço de harmonia já não é o mesmo nas reflexões de Bergeret: o eu aparece em conflito com o mundo literário como “communauté des gens du monde" e no último livro da série Histoire, o mundo idílico do pequeno Nozière, de Le Livre, aparece dissolvido da janela do escritório de Bergeret,

${ }^{141}$ Artigo publicado no dia dois de setembro de 1888 no L'Univers Illustré que não aparece em nenhuma das obras do autor. 
de onde ele vê la Pépinière ${ }^{142}$, onde seu pai lera "la philosophie de Kant et les romans de George Sand sur un banc, derrière la statue de Velléda.” (MBP, 1991, p. 225). Assim como em Gonzaga de Sá, a interioridade do personagem sofre o mesmo processo de perda de substância que o espaço da cidade, transformado pelas reformas urbanas.

A relação da cidade com os personagens de Anatole France nos parece inicialmente construída a partir de uma imagem de semelhança e harmonia que vai aos poucos se dissolvendo na figura do desiludido Bergeret, e se concretiza como espaço perdido no retorno do professor à cidade de Paris, espaço no qual só uma utopia pode salvar. Diante dessa nova situação, a relação conflituosa entre o eu e o mundo hostil se concretiza no espaço da cidade desfigurada. E essa desfiguração também acompanha o personagem. Num dos passeios pela alameda dos Olmos, Bergeret caminha pelo seu refúgio "l'âme vide de pensée et pleine d'images confuses, désolée et désirante, douce, innocente, lascive, triste, traînant sa fatique et poursuivant des illusions et des espérances, dont il ignorait le nom, la forme, le visage.” (MO, 1987, p. 959). Essa alma desfigurada encontra sua equivalência na cidade também destituída de memória, forma ou face.

Uma diferença, porém, nos parece fundamental entre as interioridades dos personagens limabarretianos e anatolianos nas suas respectivas relações com o espaço. Isaías, Machado e Gonzaga adentram de tal forma no espaço físico da narrativa, fundindo-se com a paisagem, "vivo nela (na cidade) e ela vive em mim!". Como bem observou Osman Lins, este homem ilhado no mundo, distante dos demais, mas desejoso de se misturar com os outros homens, "compensa o ilhamento criando correspondências com a paisagem e crendo-se depositário de esperanças remotas" (Lins, 1976, p. 141). No caso da narrativa anatoliana, a interioridade de Bergeret, apesar das breves confissões em meio às digressões, nunca se dissolve no espaço da narrativa. Personagem e espaço não se fundem; este último funciona apenas como um espelho para uma interioridade que não se revela, um foro interior "dans lequel le monde n'entre pas".

Isto ocorre pela distância de Bergeret em relação aos demais. Tal como se opôs ao mundano, Bergeret também critica o "vain désir de la gloire!", que levaria o homem

${ }^{142}$ Segundo nota de Bancquart, la Pépinière foi destruída em 1867, sendo que os estudantes fizeram no ano anterior uma manifestação para conservar "ce lieu champêtre". Os personagens de Nozière e Fontanet circulam por esse espaço perdido em Le Livre. 
à dissimulação, "la première vertu de l'homme civilisé". A esse homem civilizado (ou mundano), o narrador opõe o homem sincero, aquele que "dit tout ce qu'il pense et comme il le pense", ou seja, o próprio Bergeret. Esse homem sincero, porém, não consegue se expressar a não ser na solidão do espaço dos Olmos. Mesmo na livraria de Paillot, onde "la conversation est assez libre", os pensamentos de Bergeret não podem ser revelados, pois o homem que diz tudo o que pensa e como pensa "est aussi inconcevable dans une ville qu'un homme allant tout nu" (MO, 1987, p. 959-960). Ao espaço civilizado do mundo, Bergeret se opõe, mas não o afronta. Ele mantém frustrado o seu desejo de sinceridade. Nem em sua própria casa, depois da traição da esposa, o personagem encontra seu espaço. Somente a mudança para Paris, no último romance, transformará um pouco essa sensação de isolamento e oposição.

\section{Sonhos utópicos e estrutura reflexiva}

No décimo-primeiro capítulo de Gonzaga de Sá, Machado desce de sua casa "aborrecido", para se dissolver na multidão, num dia de "festa nacional" "143. Nesse trajeto, buscando se "fragmentar com o estrondo das salvas fugindo a mim mesmo, aos meus pensamentos e às minhas angústias" (GS, 1956, p. 139), Machado observa "dois populares" que discutiam "com evidente orgulho" os recursos do país. O narrador então se pergunta acerca do entusiasmo pelas coisas de uma sociedade da qual não recebiam nada em troca e o seu questionamento dá ensejo à reflexão de seu papel diante dessa "subordinação resignada”: “... que tinha eu de levar desassossêgo às suas almas, às daquela pobre gente, de lhes comunicar o meu desequilíbrio nervoso?” (p. 140-141). Diante desta situação, o narrador, num breve momento de esperança diz almejar erguer ali a sua Utopia:

"Quis ali, em segundos, organizar a minha República, erguer a minha Utopia, e, por instantes, vi resplandecer sôbre a terra dias de Bem, de Satisfação e Contentamento. Vi tôdas as faces humanas sem angústias, felizes, num baile! Tão depressa me veio tal sonho, tão depressa êle se desfez. "(p. 141).

O sonho utópico dura pouco e, logo, "desalentado", Machado abana a cabeça e chega à conclusão de que morto um preconceito, outros viriam a nascer. $\mathrm{E}$ as fontes

143 Ao que tudo indica, comemoração do 15 de Novembro, feriado nacional. É importante ressaltar o fato de que enquanto Triste Fim de Policarpo Quaresma e Recordações do escrivão Isaías Caminha tratam de momentos chaves da República, a Revolta da Armada e a Revolta da Vacina, respectivamente, em Vida e Morte de J. M. Gonzaga de Sá, a crítica é menos marcada temporalmente, mas não menos vigorosa. O ponto central da crítica é, certamente, a burocracia nacional, pela representatividade dos dois personagens funcionários públicos. 
destes preconceitos seriam para Machado a "Arte, a Ciência e a Religião". Somente "a morte dessas ilusões, só o esquecimento dos seus cânones, dos seus delírios e dos seus preceitos" poderiam dar à humanidade um "reino feliz", livre de todas as "noções entibiadoras". As questões se sucedem e o narrador vagueia caoticamente pelos pensamentos sem grandes conclusões. A conclusão cética de Machado, de pleno acordo com o "céptico, regalista, voltairiano" Gonzaga, leva-o à não-ação: "Para mim, afinal, ficou-me a certeza de que sábio era não agir. Que me propusesse apagar as atuais fontes de sofrimentos, seria preparar o nascimento de outras ..." (GS, 1956, p. 142). O percurso reflexivo de Machado parte da observação das pessoas no dia de festa nacional e fervor patriótico, tem um breve rompante de otimismo e transformação, logo cindido por um ceticismo bem ao estilo anatoliano, que repercute a irrelevância da ação. $O$ sonho utópico é a única ação possível na estrutura reflexiva do romance.

A sensação de Bergeret em relação a si mesmo e aos seus pares é muito próxima da configuração melancólica e cheia de amargura de Augusto Machado. Ainda no primeiro volume da série Histoire, no primeiro dos passeios de Bergeret pela Alameda dos Olmos ao lado do abade Lantaigne, o narrador nos revela o desalentado personagem Bergeret cuja decepção vai desde as relações conjugais com os "interminables catéchismes" da esposa e das filhas, alcançando todo o globo terrestre, "ce globe terraqué dont les habitants sont presque tous odieux ou ridicules" (MO, 1987, p. 969). Também em L'Anneau, o narrador revela a péssima relação de Bergeret com seus alunos, “il n'était pas en sympathie avec ses collègues et avec ses élèves"; com os habitantes da cidade, "il n'était point en sympathie avec les habitants de la ville"; e até mesmo com o livreiro, "Il troublait même le libraire Paillot". Enfim, "il était un être étrange, inquiétant, suspect à tous" (AA, 1991, p. 65). A solução para o desencanto do personagem não passa pelo vislumbre utópico - que se dará somente no último volume da série -, mas, como Machado, pela opção pela não ação. Para o professor Bergeret, a vida é uma "catastrophe incessante" e, diante dessa situação: "Vivre, c'est détruire. Agir, c'est nuire." (MO, 1987, p. 968). O mesmo aspecto prejudicial da ação já apareceu na alusão ao árabe de Anatole France em Numa e a Ninfa.

Neste romance, o narrador afirma que "nos grandes bailes luxuosos teria razão o árabe de Anatole France." (PS, 2006, p. 451-452). Trata-se de uma alusão a uma história de France, contida no livro Le Jardin d'Épicure. Nela, o narrador encontra com seu amigo Jean, que habitava, recluso, um velho priorado por dez anos, e lhe conta a 
estória exemplar de um mercador árabe que jogara fora o caroço de uma tâmara e o caroço atingira "le fils invisible d'un Génie". Perplexo, o árabe então reflete sobre as consequências possíveis de todas as ações. Como uma espécie de fábula, a moral da história do árabe é que qualquer ação, por menor que seja, tem consequências, muitas vezes inesperadas, e que, portanto, o sábio seria não agir.

É fundamental no caso de Barreto e de France ter em perspectiva os diálogos subjacentes que cada autor travava, por meio de seus narradores, com a sua realidade mais imediata. O desapontamento de Bergeret está ligado aos acontecimentos do caso Dreyfus, particularmente à decepção dos partidários da revisão do processo, com a absolvição do verdadeiro culpado e com a segunda condenação do capitão judeu. No caso da estória exemplar anatoliana em Le Jardin, o diálogo que o narrador estabelece com o seu tempo é com os misticismos, temática também presente na série Histoire, com a figura da vidente Claude Deniseau. O isolamento desse herói que reflete sobre si mesmo, desencantado, é trabalhado pelo jogo narrativo com as mesmas ferramentas do caso limabarretiano: a estrutura reflexiva, os passeios pela cidade, o espaço como refúgio, os rompantes utópicos. Agrega-se a isso, a estrutura jornalística e os debates da época. Em todas elas, o resultado nos romances nos parece semelhante, o tempo da narrativa não parece fluir.

Este tempo estagnado também é resultado do rompimento das cenas com potencial dramático. Já tratamos brevemente da traição da esposa de Bergeret no segundo volume da série. Retomaremos a descrição da cena, no intuito de tecer alguns comentários sobre o procedimento do narrador. A cena é marcante e inesperada e o leitor desperta da leitura reflexiva de Bergeret. Ele entra no salão da casa, sendo que o seu hábito era de se dirigir diretamente para o escritório, e lá então flagra a esposa com o discípulo. O narrador descreve a cena com o flagrante de Bergeret: "Il vit alors sur le canapé des formes humaines enlacées dans une attitude violente qui tenait de l'amour et de la lutte et qui, dans le fait, était celle da la volupté” (MO, 1987, p. 912). O foco descritivo passa então pela posição da senhora Bergeret, com "ses bas rouges amplement découverts" e de Roux com a "désordre de ses vêtements". É uma das melhores cenas do romance.

Diante desse quadro, o leitor espera alguma reação do personagem, mas o narrador reprime o potencial dramático da cena ao acelerar os acontecimentos, afirmando que "tout se transforma en moins d'une seconde". E então Bergeret vê à sua 
frente duas pessoas totalmente diferentes daquelas que tinha surpreendido, "deux personnes gênées dans leur maintien, d'aspect bizarre, un peu comique". Ele se distancia, da mesma maneira como acontece no processo de caricaturização. A ação ainda parece possível depois do flagrante, quando o narrador diz que o primeiro movimento de Bergeret "fut celui d'un homme simple et violent et d'un animal féroce", mas apesar do desejo de "tuer M. Roux et Mme Bergeret", o querer é "sans force et sans durée" e o instinto de ação do professor dura pouco, "Il fut sauvage et cruel, mais il le fut très médiocrement et durant un espace de temps si bref, que nul acte ne put suivre le sentiment...” (MO, 1987, p. 913). Primeiramente, o narrador corta a cena e acelera as transformações. Em segundo lugar, ele deixa entrever uma possível reação do personagem, mas a constância do herói intelectual prevalece. Depois do incidente, inclusive, toda a vida na casa dos Bergeret permanece igual; a única modificação é que ele não mais dirige a palavra à esposa que desiste de pedir o perdão do marido e retorna para a casa de seus pais.

Também como na traição da sra. Begeret, há uma cena de diálogo entre Machado e uma moça durante o velório do compadre de Gonzaga, Romualdo, na qual o potencial de transformação dramática parece se colocar. Nela, Machado vê uma moça sentada junto da janela, com quem começa a conversar amenidades como o tempo e a vida em Botafogo. A moça se chama Alcmena e sua positividade se contrapõe ao narrador que, obcecado com a imagem do cadáver, completa todo o pensamento da moça com algum comentário sobre a morte ou de teor pessimista. Porém, com a atração física entre os dois, Machado acaba deixando de lado as lembranças do defunto, “inebriados um do outro como se estivéssemos em um baile" (GS, 1956, p. 118). A volúpia contrasta com a situação de fundo, o velório de Romualdo. Alcmena traz para a cena a alegria que se destaca do tom geral do romance. Sobre Romualdo, a estima que ela sente pelo vizinho falecido aparece como fonte de ação, mesmo na tristeza: "Parece que dentro de nós há muita coisa de mais, molas, um mecanismo que nos empurra ... Quando fico triste, também me vem a mesma vontade ... É curioso!” (p. 119). Esse sopro de vigor, porém, deixa a cena como entrou, como uma aparição. Suas palavras repercutem momentaneamente em Machado, "dançavam-me nos ouvidos", mas a impressão é fugaz e vai se apagando enquanto a imagem do cadáver se sobrepõe novamente aos pensamentos do narrador. 


\section{La Cité et la ville}

Curiosamente, são duas cenas amorosas que dão à narrativa um potencial de transformação dramática. Em ambas, também, é a figura feminina que desperta para a possível ação. No caso de Alcmena e Machado, o narrador usa como recurso de exploração da cena a oposição entre os dois personagens e a gradual influência das palavras da moça sobre o narrador Machado. Mas, como ele é o próprio narrador, a ruptura se dá com a mudança em seus pensamentos que retornam à questão da morte, opondo-se, assim, à vitalidade de Alcmena. A presença da morte no romance como um todo é marcante, o que já indica o título do mesmo. Esta presença é reforçada pelas palavras do narrador quando logo no início afirma que a compreensão de um homem não vem da história de sua vida mas de como ele morreu, "como êle teve o doce prazer de abraçar a Morte e como Ela o abraçou" (GS, 1956, p. 37). De forma circular, é também com a morte de Gonzaga que o romance termina, sem falar no enterro do compadre de Gonzaga, que ocupa dois capítulos da narrativa.

Além da morte propriamente dita, o tom melancólico também acompanha o romance. Logo na epígrafe este tom é sentido na frase do poeta romântico Alfred de Vigny, "Seul le silence est grand: tout le reste est faiblesse" ou na de Paul Bourget, "La plaie du coeur est le silence". Ou mais tarde na forma pela qual o narrador escolhe contar as "cousas íntimas" de Gonzaga, revelando das particularidades do biografado a "sua bela obscuridade" (p. 38). Já no ciclo do professor Bergeret, as rupturas do narrador simplesmente retiram do leitor o acesso aos sentimentos do personagem, sem preencher esse vazio com a ação - de forma semelhante ao narrador limabarretiano -, nem com a interiorização, distinguindo-se aqui da perspectiva de Lima Barreto. Essa interioridade melancólica aparece principalmente nos últimos encontros entre Gonzaga de Sá e Augusto Machado, a tristeza "filosófica" do biografado se torna ainda mais presente, uma tristeza de "sentir profundamente a mesquinhez da nossa condição humana”. No fim da vida, com as decepções e frustrações, “... a sua tristeza era mais atual, mais terra-a-terra" (p. 166). Mesmo a sua palestra sempre prazerosa e por vezes jocosa, parecia então "cortada por bruscas explosões de irritação, de queixumes indignos de sua altivez ..." (p. 167).

No caso dos romances do senhor Bergeret, a presença da morte também está presente, mas de forma mais anedótica e superficial. Contígua à livraria de Paillot, fica 
"la maison de la reine Marguerite" $" 144$, como era conhecida a casa da viuva Houssieu ${ }^{145}$. Numa das cenas, o livreiro, o médico Fournerol, o arquivista Mazure e Bergeret ouvem gritos e ruídos vindos da casa vizinha e, alguns capítulos depois, os frequentadores da livraria são informados que a senhora Houssieu fora encontrada estrangulada na sua cama. O tom melancólico, mais semelhante a Gonzaga de Sá, encontraremos no romance autobiográfico Pierre Nozière (PN), publicado em 1899, entre os dois últimos volumes da série, L'Anneau e M. Bergeret. Trata-se de um livro das lembranças de infância de Pierre, narrado em primeira pessoa, cuja grande marca é a descoberta da miséria humana com o suicídio do lunetier Hamoche. Nele, todos os dias, o pequeno Pierre passeia com a senhora Mathias, sua "bonne Nannete", e passa pela ótica de Hamoche, um homem calvo "des yeux sombres et enflammés”, cujos negócios não iam muito bem. Das conversas que escutava entre Hamoche e a babá, Pierre tirava as informações necessárias para ampliar seu mundo, "les discours du lunetier m'enseignaient que la terre ne finit point [...] à la place Saint Suplice e au pont d'Iéna" (PN, 1991, p. 496).

O suicídio de Hamoche abala o mundo feliz do menino de então seis anos que "cessait définitivement de croire que la vie est un jeu". E o narrador comenta: "La cosmogonie du petit Pierre Nozière alla rejoindre dans l'abîme des erreurs humaines la carte du monde connu des Anciens et le système de Ptolémée.” (p. 498). Bancquart ressalta que, apesar do livro ser todo projetado em imagens, sem que a subjetividade se torne relevante na narrativa, a experiência da morte é central “dans l'idée que se forme Anatole France du moi" (Bancquart, 1991, p. 1295). O que salva a obra da superficialidade é exatamente, segundo a crítica, a presença constante desta alusão à morte, seja nas pedras mortas da cidade ou na melancolia daquilo do que não mais existe.

${ }^{144}$ Os habitantes da cidade deram esse nome à residência da velha Houssieu pois acreditavem que Marguerite d'Écosse, esposa de Luis XI, teria vivido ali em 1438. No romance, um dos frequentadores da livraria, o senhor Terremondre, defende que a casa teria sido construída em 1488 por um burguês que tivera como esposa Marguerite Larrivée. Essas informações estão nas notas da edição da Pléiade.

${ }^{145}$ A cidade onde se passa a ação nunca é nomeada, somente a rua des Tintelleries, onde fica a livraria. O espaço só adquire relevância no último volume com a mudança de Bergeret para Paris. A cidade, o seminário e algumas datas são nomeadas com asteriscos (la ville de ***, le séminaire de ***, le cardinal-archevêque de $* * *$, en $\left.189^{*}\right)$. Essas referências sugerem uma atemporalidade da narrativa. O tempo só aparece claramente nas conversas que envolvem Bergeret. A única indicação da data do romance aparece durante uma conversa na livraria de Paillot, "nous sommes en 1897" (OM, 1987, p. 799). 
Este saudosismo tem uma relação direta com a figuração da cidade nas obras aqui estudadas. Enquanto a presença da cidade republicana (la ville) desaponta tanto o narrador limabarretiano como o anatoliano, existe uma relação de proximidade com um espaço que reside na memória, que chamaremos de cidade internalizada (la cité), a "ville" considerada sob o aspecto da pessoa moral ${ }^{146}$. O resgate da história a partir da cidade destituída de forma é uma espécie de manifesto regressivo, mas que ao rememorar uma origem, um tempo anterior, confere ao mundo um sentido, um valor. É neste sentido valorativo que a pessoa moral dos narradores anatoliano e limabarretiano concebem sua cité.

É neste exame sobre si mesmo que podem ser lidas as pedras mortas da cidade de Paris, sobre as quais o senhor Bergeret devaneia diante do apartamento que sua irmã Zoé encontra para ele morar juntamente com sua filha Pauline. A visão da Pépinière, onde os mais velhos diziam que "des allées couraient en labyrinthe parmi des arbustes, entre des treillages peints en vert" (MBP, 1991, p. 225), assim como a Alameda dos Olmos, são figurações do espaço interior do herói intelectual. No caso de Anatole France, é o esconder da interioridade do personagem que acaba se metamorfoseando numa experiência da cidade, distanciando-se de la ville e aproximando-se de la cité. A pessoa moral da cité anatoliana estabelece uma relação próxima entre reflexão e espaço, mas se utiliza ao mesmo tempo desta cité como espaço de esconderijo para a interioridade. Nesta operação narrativa, a identificação com o leitor que não partilha das mesmas referências do contemporâneo ao escritor torna-se difícil. O humanistmo anatoliano sofre aqui da falta de uma essencialidade que torna a obra literária atemporal, pois o homem anatoliano, seu herói intelectual raramente revela suas fragilidades.

No caso limabarretiano, apesar do tom reflexivo, a identificação ainda é possível. Talvez pela própria relação imbricada entre autor e narrador. Para alguns críticos da obra limabarretiana, a luta entre o personagem e o mundo hostil ficcional se espelha na vida do autor. Para Sérgio Buarque de Holanda (2012), a obra de Lima Barreto é uma "confissão mal escondida", na qual o autor realiza uma transfiguração em arte da confissão de amarguras íntimas, ressentimentos e malogros, uma "refundição

${ }^{146}$ No encalço da formação da ideia de público moderno, Erich Auerbach (2007) examina como a unidade advinda de la cour et la ville, no grupo dos honnêtes hommes, o indivíduo se constitui como pessoa moral, diante de um mundo descristianizado. Os dois autores aqui estudados, ao internalizarem o passado na cidade, se arvoram semelhante papel de referência moral. 
artística". Para Holanda, enquanto em Machado de Assis ${ }^{147}$, é detectável a evasão e o refúgio, Barreto estaria entre os escritores que "menos se escondem e menos se dissimulam". Numa interpretação oposta, Alceu Amoroso Lima, em prefácio ao Gonzaga de Sá, afirma ser a obra de Lima Barreto, antes de tudo, “a expressão do homem sem ressentimentos, mas também sem ilusões" e de seus livros transpareceria "um grande desencanto de viver". Na refundição artística de Lima Barreto, essa desilusão e esse desencanto se revelariam "na sensibilidade frustrada dos personagens e da personalidade literária do autor Lima Barreto" 148 que se integram na obra literária.

Em Gonzaga de Sá, a marca da cité limabarretiana adentra a ville. A incorporação da cidade como parte integrante do personagem, "Vivo nela e ela vive em mim!” (GS, 1956, p.40), faz da ville um museu vivo, recuperando a história como elemento do vivido. As “cousas mortas" que Gonzaga busca nos sobrados, telhados e sacadas transformam a história em memória. O espaço que lhe resta da cité destroçada está ligado à memória, a um passado idealizado, a uma forma de vida diferente na cidade, e, principalmente, ao espaço crítico ensejado pela relação entre personagem e paisagem. Esse tempo passado revivido na relação de Machado com a cidade é semelhante ao tempo passado refletido por France, com a diferença flagrante no processo de internalização dos personagens. São essas duas experiências que os narradores opõem à decepcionante cidade republicana e fazem com que a experiência do tempo acompanhe o processo de estagnação da narrativa, seja na circularidade do passado refletido de France ou na estagnação do passado revivido de Barreto.

Segundo Boris Tomachevski ${ }^{149}$ (1971), a trama é a organização dos acontecimentos da fábula dentro da obra. As obras com trama obedecem, segundo o crítico russo, ao princípio de causalidade e se inscrevem numa cronologia, a exemplo das novelas, romances e do poema épico. Já nas sem trama, a sucessão dos

147 As comparações entre Lima Barreto e Machado de Assis são bastante recorrentes na crítica brasileira. A interpretação mais comum, como é o caso de Holanda, centra a compreensão no biografismo limabarretiano versus a dissimulação machadiana.

$148 \mathrm{Na}$ recém publicada "Lima Barreto: uma autobiografia literária", organizada por Antonio Arnoni Prado (2012), o crítico sugere que a "impassibilidade sensível e a vocação para o fracasso do personagem Frédéric Moreau”, personagem central de L’Éducation Sentimentale (1969), de Gustave Flaubert, teriam inspirado o desencanto "na sensibilidade frustadas dos protagonistas e da personalidade literária do autor Lima Barreto". O crítico também sugere a influência de Sthendal, de Le Rouge et le noir (1830), como uma obra que poderia ter "fecundado a percepção de análise no enfoque do isolamento do herói, em aberto confronto com a sociedade", particularmente em Isaías Caminha e em Policarpo Quaresma.

149 Texto intitulado "Temática", incluído na coletânea de artigos dos formalistas russos". Ver Eikhenbaum et. al. (1971). 
acontecimentos não obedece a nenhuma causalidade interna, seria o caso da poesia descritiva e didática, da lírica e dos escritos de viagem. No caso dos romances de Bergeret e de Gonzaga, não temos uma sucessão de acontecimentos seguindo uma causalidade interna, mas um fluxo de reflexões que se dão a partir de breves estímulos dramáticos que suscitam, por sua vez, novas meditações. Estamos, portanto, lidando com romances sem trama nos termos de Tomachevski, porém, de tipos diferentes ${ }^{150}$. A estagnação da narrativa, diante da qual a sequência dos acontecimentos se dá ou pelo passado revivido nas lembranças de Machado ou pelo passado refletido nas opiniões de Bergeret, parece-nos ser um elemento comum nas duas narrativas. Isso porque, como vimos, os projetos de transformação dramática são constantemente interrompidos pelo narrador.

As diferenças, porém, nos parecem significativas. Já tratamos das questões concernentes ao personagem e sua simbiose com a paisagem, internalizada por Barreto e construída de forma estilizada em France. Há ainda a diferença de composição entre as duas obras: enquanto a série Histoire é resultado de uma publicação seriada, o romance Gonzaga de Sá foi escrito como obra completa. No caso da série anatoliana, a ausência da trama é ainda mais presente pela organização particular das partes publicadas anteriormente, como numa colagem. Os conflitos entre os diversos grupos de personagens se alternam na narrativa, sendo que ao narrador coube, ao conferir uma forma acabada à obra, dar uma certa organicidade e ligação entre esses conjuntos dramáticos. Talvez o último romance da série, M. Bergeret à Paris, se diferencie um pouco dos antecedentes, em função, principalmente, da mudança do personagem para o centro dos acontecimentos políticos da época, Paris - troca que reforça a trajetória peripatética de Bergeret, ao mesmo tempo em que os grupos aristocráticos vão se desarticulando gradativamente. Inclusive, na conclusão desse último volume, a diluição da trama dá a impressão ao leitor de uma dissolução da obra, que se encaminharia ou para a sátira ou para a alegoria.

Um último elemento distintivo entre os dois narradores diz respeito ao tempo. Em Gonzaga de Sá, tem-se a impressão na leitura da obra que o tempo não segue um fluxo. Talvez isso tenha a ver com a inspiração no gênero biográfico, como afirma

\footnotetext{
${ }^{150} \mathrm{Na}$ categorização das obras de Barreto e France, nem mesmo a inscrição como romance é isenta de questionamentos. No caso específico de Anatole France, a série Histoire é vista por MarieClaire Bancquart como "un cas exemplaire de la crise du roman au tournant du siècle" (Bancquart, 1987, p. 1325).
} 
ironicamente o prefaciador Lima Barreto. Talvez venha do fato de o romance se iniciar com o anúncio da morte do personagem central e terminar com o seu falecimento, dando à narrativa uma estrutura temporal circular. Um dos indícios temporais em Gonzaga de Sá está nas observações da natureza e da cidade: no céu ao entardecer no Passeio Público, no tom de violeta perdido ao fim da viagem de bonde, na tarde dúbia na Avenida Beira-Mar. Esses sinais temporais, porém, não fornecem ao leitor elementos de progressão temporal. $\mathrm{O}$ tempo parece estático. O elemento que se transforma está na relação entre a paisagem e os sentimentos do personagem, como já sugerimos a partir da perspectiva de Osman Lins. As mudanças se dão no meio e não no decurso temporal. A cidade se modifica ou pelas transformações reais ou pela incorporação do passado na memória viva de Gonzaga.

Diferentemente desse tempo estagnado que dá lugar ao movimento internalizado da paisagem no personagem, temos num trecho de metanarrativa uma outra estrutura. No capítulo inicial, com a morte de Gonzaga, o narrador nos revela o conteúdo de uma folha encontrada em meio aos papéis que lhe foram legados pelo falecido amigo, cujo título era "O inventor e a Aeronave". Nessa breve narrativa, as marcas temporais estão bem mais presentes: "Desde dez anos", "já no dia seguinte", "veio a aurora", dentre outras. Terminada, porém, a transcrição dessa história, com o fracasso da máquina de voar, o narrador comenta a "fantasia" do amigo:

“... entendi bem que êle queria dizer que o Acaso, mais do que outro qualquer Deus, é capaz de perturbar imprevistamente os mais sábios planos que tenhamos traçado e zombar da nossa ciência e da nossa vontade" (GS, 1956, p. 46, grifo nosso).

O acaso é um acontecimento fortuito, imprevisível, que prescinde de uma sucessão de fatos com causas e consequências. Usado em maiúsculas e equiparado a algo divino, "mais do que outro qualquer Deus", esse comentário do narrador funciona, como vimos no caso da descrição da morte de Gonzaga, como um interruptivo do fluxo de acontecimentos na narrativa. Ainda que a história dentro da história tenha mais marcas temporais, a interpretação final de Machado retrai esse tipo de construção linear do tempo na narrativa, zombando dos "planos que tenhamos traçado" e "da nossa vontade". Em Gonzaga de Sá, mais do que em qualquer outro romance de Lima Barreto, a simbiose entre espaço e personagem retira da temporalidade a primazia da sequenciação dos acontecimentos. 
Um último indício desse tempo estagnado em Gonzaga de Sá pode ser pensado a partir da posição dos personagens em relação ao decurso temporal. No romance, três tempos aparecem fundidos: o passadismo de Gonzaga, o futuro do filho do compadre Romualdo, Aleixo Manuel, e o presente da cidade e do narrador Augusto Machado. Gonzaga representa a tradição, "Eu sou Sá, sou o Rio de Janeiro" (GS, 1956, p. 59). Machado incorpora o espaço como equivalente humano da cidade, inclusive desejando expulsar todo o intruso da terra pela qual sua ascendência tanto sofreu, "E vão-se, que isto é meu!" (p.41). Aleixo simboliza o vislumbre do futuro que o narrador percebe no "olhar de sibila" (p.166) de Gonzaga para o afilhado. Nesta fusão dos tempos, juntamente com a restrição da ação, todo o romance poderia se passar num só dia, se não fosse o enterro de Romualdo que, ao mesmo tempo que introduz a cena de potencial dramático do romance, traz para o romance a figura de Aleixo como vislumbre de futuro, também anulado pelo narrador que vê no rapaz a repetição da história de suas próprias desilusões.

Já na série Histoire, esse aspecto temporal é elaborado mais tradicionalmente. Apesar de se tratar de uma coletânea de crônicas publicadas em jornal, compromentendo a sequência internalizada da narrativa, há, na montagem narrativa, um contínuo temporal que se estrutura a partir da luta pela vaga de bispo disputada por Guitrel e Lantaigne. Essa trama submersa do mundo clerical organiza a narrativa, alternando ainda as reflexões de Bergeret e as maquinações nacionalistas. Há uma estrutura dual nas obras da série que nos parece ter sido elaborada pelo autor na organização dos volumes.

Um indício dessa elaboração temporal na série do senhor Bergeret pode ser visto nas marcas do tempo que aparecem nos passeios pela Alameda dos Olmos. Essas marcas do tempo se configuram a partir de uma concepção temporal que, segundo Bancquart, atravessa toda a obra de France. Para a crítica, o gosto do autor pelo passado e pela história está fundamentado "dans une vision de la succession de générations qui recommencent les mêmes expériences, mourant et renaissant toujours..." (Bancquart, 1991, p. 1302). No primeiro volume da série Histoire, logo no primeiro passeio pelos olmos, uma marca de tempo é repetida no início de dois parágrafos: "Ce soir-là". Na sequência, há um longo diálogo entre Bergeret e Lantaigne, interrompido por outro indicativo temporal "au moment où", com a aproximação do abade Guitrel. A repetição no início das frases é um procedimento constante do narrador anatoliano. Já tratamos da 
repetição como recurso de desqualificação do argumento do outro, mas aqui ela aparece com outro uso estilístico, assim como em L'Anneau, depois da traição da esposa de Bergeret. No trecho, o narrador fala sobre o personagem:

"Il n'était pas triste. Il n'était pas gai non plus.

"Il n'était pas beau, il n'était pas jeune, il n'était pas riche, et il n'était pas triste parce que sa sagesse approchait de la bienheureuse ataraxie, sans toutefois y atteindre. Et il n'était pas gai parce qu'il était sensuel, et que son âme n'était point exempte de désirs et d'illusions." (AA, 1991, p. 65, grifos nossos).

Dois recursos aparecem nesse trecho: a repetição anafórica e a utilização dos mots-outils. A anáfora é a repetição de uma palavra ou grupo de palavras no início de duas ou mais frases com o intuito de enfatizar o termo repetido. A frase "Il n'était pas triste. Il n'était pas gai non plus" é inclusive repetida da mesma maneira no segundo e no quarto parágrafos do capítulo. Esse recurso estilístico, usado na maior parte das vezes em textos poéticos, trata aqui dos sentimentos e das características pessoais de Bergeret. Do ponto de vista do efeito estilístico, o recurso dá ao trecho um ritmo particular, cadenciado e constante, como algo que se repete infinitamente. De um ponto de vista mais geral, essa repetição frasal aponta para um tipo de temporalidade trabalhada até o limite na série Histoire com a alegoria dos Trublions no último romance em Paris: uma temporalidade cíclica. Além disso, ao estilizar os sentimentos, o narrador anatoliano retoma a perspectiva de esconder a interioridade, como sugerimos anteriormente.

Outro recurso importante utilizado por France são os mots-outils, cuja descrição vimos anteriormente. Quando o narrador afirma que Bergeret não era triste "porque sua sabedoria se aproximava da bem-aventurada serenidade", ou ele não era alegre "porque era sensual, e sua alma não estava livre dos desejos e ilusões", os termos que ligam causa e consequência são arbitrários. As orações explicativas não oferecem um verdadeiro esclarecimento das razões da tristeza ou da não tristeza. De um lado, ele não era triste, por ser um sábio sereno, de outro ele não era feliz por ser sensual. Nenhuma das explicações justifica a afirmação principal. Esse jogo estilístico é uma das características da obra de France apontada pelo critico Albert Thibaudet, nas repetições, nas negações e descompassos entre os conectivos das orações que dariam à narrativa anatoliana a sensação de algo inconclusivo e que se perpetua. 


\section{Resíduo caricatural}

Em Gonzaga de Sá e na série Histoire confrontamos até o momento as relações entre personagem e meio, a estagnação da narrativa, as duas cidades e suas respectivas temporalidades. Do primeiro aspecto, concluimos pela interiorização da natureza na narrativa limabarretiana e pela artificialidade dessa construção na série Histoire. Do ponto de vista da trama, os dois narradores operam rupturas no contínuo narrativo anulando o potencial dramático de algumas cenas. Da simbiose entre espaço e personagem temos um tempo vivido e um tempo refletido moral, este último ligado à cité e em oposição à ville. As temporalidades resultantes das duas perspectivas narrativas distinguem-se entre tempo cíclico de France e tempo compactado em Barreto que integra nos personagens centrais o passado, o presente e o futuro. Se em Gonzaga de Sá, o narrador limabarretiano foi capaz de ultrapassar a caricaturização de Isaías Caminha, o mesmo não se pode dizer da narrativa anatoliana, na qual a crítica social tende, no último romance, para o mesmo caminho. Ainda que no romance de Gonzaga, muitos personagens sofram o mesmo processo de caricaturização, o núcleo central dá à obra um tom diferenciado. No caso da série anatoliana, os limites da estrutura de coletânea de artigos e os acontecimentos políticos do caso Dreyfus levaram o narrador para um caminho que antecipa a sátira dos pinguins.

A interferência dos acontecimentos reais na obra literária já foi abordada na transposição do escândalo do Panamá. Alguns elementos desse período permanecem na série Histoire, principalmente nos primeiros volumes, ainda que seja o caso Dreyfus o tema central nos debates e observações de Bergeret. Em Le Manequin, Bergeret senta-se ao lado de Lantaigne na Alameda dos Olmos e ao mesmo tempo que o professor tenta esconder uma notícia, "à masquer la partie de texte qu'il tenait pour la plus expressive" (MO, 1987, p. 963), o narrador revela outra manchete que anunciava "un de ces incidents communs dans notre vie parlementaire, depuis le mémorable triomphe des instituitions démocratiques". Trata-se novamente do caso do Panamá. Na sequência, um comentário do narrador ironiza o ocorrido: “Les Saisons alternées et les Heures enlacées avaient ramené en ce printemps, avec une exactitude astronomique, la période des scandales. Plusieurs députés avaient été poursuivis dans ces mois ..."151

${ }^{151}$ Segundo nota de Bancquart, o evento diz respeito ao caso do Panamá, particularmente com as prisões de personalidades envolvidas no escândalo em março e abril de 1897. 
Na revelação que faz da matéria escondida do abade Lantaigne por Bergeret, o narrador de L'Orme traz para a cena o caso do Panamá somente para, no comentário seguinte, transformar esse evento circunstancial num acontecimento natural. Nesta transformação, o narrador reforça a concepção cíclica do tempo que vimos tratando até o momento, ao afirmar que as estações e as horas teriam trazido à tona o período de escândalos "avec une exactitude astronomique". Como eventos que se repetem, inaugura-se "la période des scandales". Do ponto de vista semântico, o narrador transfere dois campos, o da natureza (estações) e do tempo (horas), para o contexto das transformações políticas, passando pela fixação do momento (exatidão astronômica), e indicando algo que, como na natureza, faz parte de um fenômeno comum. Ao realizar essa operação, o narrador atribui aos escândalos políticos a temporalidade dos eventos naturais, internalizando a concepção de tempo cíclico a partir de uma transferência de campos semânticos. Essa temporalidade, na qual o tempo deixa de ter uma progressão para girar em círculo, como as estações que se repetem, é mais um sinal da utilização do tempo na narrativa de Histoire ${ }^{152}$. E aponta para o limite desse tipo de representação nos romances de France, nos quais a caricatura e a alegoria funcionam como recurso recorrente na ausência de uma solução interna ao romance. A concepção do autor Anatole France parece se sobrepor à perspectiva narrativa.

Semelhante processo ocorre em Gonzaga de Sá, no momento em que o narrador Augusto Machado alegoriza o seu próprio projeto utópico, a sua República. Na oposição que cria, o narrador contrasta Utopia e República a um certo tipo de Arte, Ciência e Religião: a arte canônica, os delírios da ciência e os preceitos religiosos; todos eles elementos de estagnação, dogmáticos. A Utopia e a República estariam sempre ameaçadas pelas ditas noções enganadoras. Diferentemente da caricaturização de L'Histoire, a oposição surge aqui da mesma lógica temporal que tratamos acima. Passado e futuro são trazidos para um presente diante do qual é impossível para o personagem qualquer tipo de transformação. A crítica aqui vem da própria situação do narrador e do personagem, o primeiro marcado pela origem negra e o segundo prestes a morrer. Assim como em Isaías Caminha, a crítica é incorporada na narrativa, não mais na opção caricatural, mas na estrutura temporal do tempo estagnado.

152 No romance Sur la Pierre Blanche (1905), passado, presente e futuro se fundem nessa história de Paris, das escavações de Roma e da cidade utópica e comunista do futuro sonhado. Se cada um desses tempos não fosse separado na estrutura da narrativa, talvez fosse possível a aproximação com a perspectiva temporal de Gonzaga de Sá. 
A crítica do escritor brasileiro à arte como uma das "noções entibiadoras" nos chama a atenção. Mas, ela só pode ser compreendida recorrendo a outros textos de Lima Barreto. No conto Harakashy e as escolas de Java, na "peregrinação sentimental" do narrador pela ilha de Java, por exemplo, é possível observar mais claramente o que seria essa arte enganadora, uma construção do literato e não do escritor. A literatura de Java é como "um jogo de prendas", realizada em grande parte pelos médicos, "os mais constantes fregueses da Academia", para quem a boa literatura "é constituída por vastas complicações de cousas de sua profissão, escritas laboriosamente em um jargão enfadonho com fingimentos de língua arcaica." (HS, 2008, p. 42). O literato de Java é um disfarce para a caracterização do literato brasileiro, em oposição ao escritor sincero e honesto do prefácio da seleção de contos. Ao escritor, Barreto aconselha largar velhas regras e aproveitar dos gêneros "o que puder e procurar, conforme a inspiração própria", no intuito de difundir as grandes e altas emoções para "soldar, ligar a humanidade em uma maior" (p. 10).

Na utopia de Augusto Machado, só é possível vislumbrar uma transformação, uma ligação da humanidade em algo maior, se aquela arte em maiúsculas for realizada não pelo literato, mas pelo escritor sincero e honesto. Num entendimento mais amplo, a Utopia do narrador de Gonzaga de Sá só pode ser realizada quando o fim da literatura militante limabarretiana for alcançado, a ligação entre a humanidade. Esta literatura, como Lima Barreto confessa, é inspirada na obra de Anatole France, cujos livros "se não visam a propaganda de um credo social, têm por mira um escopo sociológico" (IL, 1956, p. 72).

Gonzaga de Sá é o único dos romances limabarretianos ${ }^{153}$ em que a opção caricatural não toma as rédeas da narrativa, deixando espaço para um tipo de utopia que se liga ao espaço. Para Carmem Lúcia Figueiredo, é no espaço da desesperança, como na interpretação sentimental da utopia de Augusto Machado, que se situa a ironia limabarretiana: "nos espaços vazios, outrora ocupados pelo sonho de realizações grandiosas" (Figueiredo, 1998, p. 12). O próprio Augusto Machado explicita esse lugar da ironia em Gonzaga de Sá, "a ironia tinha disfarçado a mágoa de não achar onde aplicá-las e surdas efervescências de raiva deviam viver sepultadas no seu íntimo" (GS,

153 Triste fim de Policarpo Quaresma também apresenta uma estrutura diferenciada, na qual a loucura exerce um papel fundamental. Porém, não nos alongaremos neste romance, pois nele a relação com Anatole France nos parece bastante reduzida. Já em Numa e a Ninfa, como em Isaías Caminha, o caricatural volta a orientar a narrativa, com a figura de Bogóloff. 
1956, p. 150). São nesses espaços vazios, nos quais a ironia trava uma relação com a intimidade desse herói intelectual desiludido, que é possível vislumbrar o espaço dos desejos frustrados, como na figura de Aleixo, em quem Machado vê a si mesmo, nos “dolorosos desenganos desta minha mocidade irrequieta e desigual ..." (GS, 1956, p. 161).

A relação que o narrador e Gonzaga travam com o espaço nesse romance nos parece estar nesta mesma chave de "dolorosos enganos", já que incorpora os sentimentos do personagem e do narrador. Esta incorporação substitui a necessidade do caricatural tão presente na obra de Lima Barreto e tão próxima das soluções anatolianas. Ao mesmo tempo, as semelhanças entre as duas obras também são muitas e aparecem, certamente, nos elementos que os autores trazem para as narrativas. Um destes elementos está na premissa de sinceridade autoral. No prefácio ao segundo volume de La Vie Littéraire, a sinceridade, a naturalidade e a verdade são características às quais o escritor francês atribui a boa acolhida de seus textos críticos, transponíveis certamente para a atividade literária ${ }^{154}$.

Às virtudes da sinceridade, naturalidade e verdade, agregam-se as imperfeições desculpáveis: a incapacidade de esconder os defeitos, as eventuais contradições e a mania de "faire à tout propos des contes avec mes souvenirs et mes impressions" (VL2, 1925, p. IV). Apesar de contar como uma falha, essa mistura de impressões e lembranças autorais amplia o escopo da obra, pois quando os escritores falam de si mesmos, "c'est comme s'ils parlaient de toute le monde" (p. V), e suas confissões formam "un manuel de confession à l'usage de la communauté tout entière.". Em Amplius!, são também os "escritores sinceros e honestos" que, no dever de reformar usanças, sugerir dúvidas, levantar julgamentos, difundir grandes e altas emoções, devem contribuir para ligar a humanidade entre si. No caso de Lima Barreto, os defeitos são perdoados se a literatura cumprir um intuito maior: de ligar a humanidade, beirando por vezes o salvacionismo ${ }^{155}$.

Além dessa sinceridade narrativa como pressuposto da escrita dos dois autores, Bergeret e Gonzaga (e Machado) podem ser vistos, enfim, como irmãos literários no itinerário peripatético que realizam nessas duas obras, na relação íntima com o espaço

\footnotetext{
${ }^{154}$ Lembrando que o formato dos romances de France, salvo Le Lys Rouge, é de coletâneas de textos publicados na imprensa. Portanto, aquilo que vale para o crítico deve ser estendido ao romancista.

${ }^{155}$ Como ao final de Amplius!, quanto Barreto se refere às palavras dos evangelhos: "amai-vos uns aos outros" (HS, 2008, p. 12).
} 
onde se passam algumas cenas e em seu tom digressivo das mesmas. Em termos mais amplos, as semelhanças dizem respeito a uma concepção de mundo desses personagens, tipos humanistas na passagem para o século XX, e, do ponto de vista da composição das obras, da mistura de outros tipos de escrita nos romances. No caso limabarretiano, a presença destes outros tipos de escrita em Gonzaga de Sá foi um dos temas da tese de doutorado de Marcos Scheffel (2012), um estudo do cruzamento entre crônica, diário e romance na obra de Lima Barreto que buscou elucidar a presença da história no romance. Para Scheffel, em Barreto, "a escrita histórica necessitava de certa dose de imaginação criativa"156 (Scheffel, 2012, p. 61), como no belo exemplo da figura do boi como símbolo de resignação presente tanto em crônicas, como em Gonzaga de $\operatorname{Sá}^{157}$. Scheffel também observou o expurgo da caricatura em Gonzaga de Sá, salvo na figura de Xisto Beldroegas; num movimento bastante diverso do romance de estreia.

Para traçar uma imagem das dissonâncias entre os dois autores, usaremos, para finalizar este trecho, o elemento da loucura na vida e/ou na obra de ambos. Como já foi dito, a história de Gonzaga de Sá é atravessada por duas internações de Lima Barreto. $\mathrm{Na}$ distinção que faz dos três movimentos gerais da obra de Lima Barreto, Antonio Arnoni Prado afirma que o terceiro deles se configura numa mescla entre "o inconformismo diante da expansão das elites e a submissão irremissível dos despossuídos" (HS, 2008, p. XXV) ${ }^{158}$. Esse terceiro movimento integraria as intervenções mais profundas do autor rebelde e melancólico, principalmente nos últimos anos de vida depois da dolorosa experiência do hospício. Essa melancolia é parte da escrita de Gonzaga de Sá, construída particularmente na simbiose entre personagem e paisagem, no refúgio do eu diante de um mundo hostil e de uma realidade cujas barreiras parecem intransponíveis. É nela que a ironia ocupa o espaço deixado pela utopia frustrada, não no elemento da caricaturização que antecipa a sátira e se coloca em outro movimento da obra limabarretiana, do "picaresco moralizante".

156 Vimos no capítulo anterior que a concepção de história também incorpora esse viés imaginativo em France. Muito provavelmente uma influência de Ernest Renan.

${ }^{157}$ Retomaremos esse trecho no próximo capítulo.

${ }^{158}$ No prefácio à edição de 2008 de Histórias e Sonhos, o "mais sinóptico dos livros de Lima Barreto", segundo o prefaciador Antonio Arnoni Prado, o crítico delineia três movimentos de Barreto no decorrer da coletânea de contos. No primeiro movimento estaria a "descrição do cenário humilde da gente apartada do progresso", no segundo, estaria o "picaresco moralizante" de personagens como Gregoróvitch, Flamel, dentre outros exóticos do rol limabarretiano, e no terceiro uma mescla do "inconformismo diante da expansão das elites e o da submissão dos despossuídos" que aparece principalmente depois da experiência da loucura. Na coletânea, esse movimento é representado pelos contos Harakachy e As escolas de Java. 
No caso de Anatole France, em uma tradução que realizei de um conto do autor, "Balzac, le prince du mal", 159 , apontei um aspecto de sua obra que diz respeito ao distanciamento ao qual constantemente aludimos na análise dos romances. Trata-se de uma recusa em revelar feridas, mesmo nas obras mais autobiográficas do escritor. $\mathrm{O}$ distanciamento desse analista das ilusões - como o definiu Joseph Conrad (2010) trata os loucos com piedade e uma identificação, digamos, literária. Porém, não se deixa levar pela própria pena. No ponto de conversão da história em literatura, enquanto Gonzaga de Sá integra-se à matéria literária, Bergeret observa e comenta o mundo à sua volta. O tempo circular é fruto de um pensamento autoral introduzido na narrativa, enquanto o tempo estagnado é resultado da relação espaço-temporal e existencial do personagem. Enquanto Gonzaga de Sá é a melhor realização romanesca de Lima Barreto, fruto da complexidade das imagens suscitadas pela narrativa, os romances da série Histoire se confundem na equivalência entre realidade e ficção, relegando à matéria narrativa uma artificialidade na qual prevalecem as ideias do escritor acima da complexidade imanente da tessitura narrativa.

${ }^{159}$ Ver Almeida (2001). 


\section{O Moralista}

No último romance da série Histoire, o tempo é alvo das reflexões de Bergeret. Dentre as inúmeras divagações do personagem, ele afirma: "Car, puisque le temps n'existe point en réalité et que la sucession des faits n'est qu'une apparence, tous les faits sont réalisés ensemble et notre avenir ne s'accomplit pas. Il est accompli” (MBP, 1991, p. 223-224). Bergeret faz essa observação durante uma visita à casa onde passara a infância, acompanhado de sua irmã Zoé. Indicamos antes que o tempo na narrativa anatoliana gira em torno de si mesmo, é um tempo cíclico. Mas, para entender esse tempo que se repete indefinidamente são necessários alguns outros elementos.

Um dos elementos deste tempo cíclico pode ser pensado a partir de alguns recursos estilísticos usados pelo narrador anatoliano. Em decorrência do momento que escreve a obra, a concepção temporal nos parece também influenciada pelo universo polarizado no qual o autor escreve, a luta entre dreyfusards e antidreyfusards em torno do processo Dreyfus. De forma simplificada, o narrador posiciona de um lado os intelectuais, que se utilizam da palavra como objeto de luta, e de outro, os nacionalistas que se utilizam da repetição para fortalecer argumentos vazios. $\mathrm{O}$ narrador de $M$. Bergeret reforça recorrentemente, quase sempre de forma irônica, o efeito da repetição no grupo dos monarquistas: "Cette parole, chaque soir répétée, soulevait dans l'assemblée entière un enthousiasme auguste et formidable” (MBP, 1991, p. 319). Mas, não é somente em direção ao inimigo que o recurso é utilizado. Ele também aparece na descrição da República de Bergeret, diferenciando-se, porém, pelo uso anafórico, que busca enfatizar o termo repetido, como uma espécie de mantra, como é o caso do futuro idealizado por Bergeret: "Il n’y aura plus de marchands de vin dans ma république. Il n'y aura plus d'acheteurs ni de vendeurs. Il n'y aura plus de riches ni de pauvres." (p. 290).

Do lado dos antidreyfusards, além dessa estratégia da repetição, o narrador se utiliza também do recurso depreciativo, de forma semelhante ao que faz em relação ao capuchinho Ange. O primeiro indício depreciativo está nas observações de Bergeret acerca do cachorro Riquet, cujo lado "selvagem" é transposto para o grupo dos nacionalistas, antisemitas e antidreyfusards. Como Riquet, os selvagens não têm passado, o que importa é um presente eterno no qual nada se modifica. A relação entre 
Riquet, o cão, e o grupo antidreyfusard é sugerida nas palavras de Bergeret quando ele diz que o animal é fraco, amante da injustiça; enfim, um "jouet des apparences" e finaliza, se dirigindo ao animal: "Toi aussi, tu as des haines de race, des préjugés cruels, le mépris des malheureux" (MBP, 1991, p. 229). Fica claro que a acusação não se destina somente ao cachorro Riquet, mas, por equivalência, ao comportamento do grupo antidreyfusard. A concepção cíclica do tempo se enuncia estilisticamente a partir dessa interpretação do comportamento dos antidreyfusards, desprovida de história, associada à perda do poder da palavra pelos intelectuais. O sonho utópico perde sua força na mesma medida em que as palavras perdem parte do seu poder de persuasão. Diante deste novo quadro de forças no pós-caso Dreyfus, um dos caminhos críticos da narrativa anatoliana se concretizará no método satírico.

No caso de Lima Barreto, o tempo em Gonzaga de Sá se apresenta, como vimos, estagnado. Isso não quer dizer, porém, que não exista um tipo de sucessão temporal na obra, mas que, a passagem do tempo se revela mais na estreita relação entre os personagens e a paisagem do que num fluxo de acontecimentos. $\mathrm{O}$ passado que o narrador retira da residência de Gonzaga, onde "tinha penetrado no passado, no passado vivo, na tradição" (GS, 1956, p. 102), e o futuro sem perspectiva do sobrinho Aleixo, em quem o narrador vê a repetição de sua própria história, fazem parte do eixo presente da narrativa, pois não se realizam nem na cidade passadista, nem na cidade futura. $O$ tempo em Barreto, mais conectado à tessitura do romance e aos personagens, difere, como já sugerimos, da concepção temporal de France, presente mais nas reflexões do narrador e de Bergeret ou nos procedimentos estilísticos.

Isto não quer dizer que na obra de France, a compreensão do tempo não tenha relação com os personagens. Dentre o rol de figuras que aparece no romance, em diálogo com Bergeret, está, o sr. Panneton de la Barge, um nobre que foi "criado no culto do exército" e não deseja ver nada modificado. Ele defende a manutenção do poder do exército com a frase "Ne touchez pas à la hache" $" 160$. Esse desejo de imobilidade do grupo nacionalista aparece na conversa que o sr. de la Barge tem com Bergeret; na verdade, trata-se do pedido de um conselho referente a seu filho Adhémar, ex-aluno do professor. Adhémar é pouco estudioso e ocupa seu tempo com festas e diversões, mas o pai quer que ele tenha um diploma de ensino superior para prestar um

\footnotetext{
${ }^{160}$ Segundo nota, essa frase foi pronuciada no cadafalso pelo inglês Charles I em 1649.
} 
ano de serviço militar e não dois como estipulava a lei ${ }^{161}$. O futuro desejado por la Barge para o filho é a manutenção do status quo, ou seja, encontrar uma forma de permanecer da mesma maneira e manter os privilégios anteriores às leis republicanas.

\section{O exótico e o caricatural em Bergeret e Gonzaga de Sá}

Uma das formas encontradas para o exercício crítico da literatura militante diante deste tempo estagnado na narrativa romanesca de Lima Barreto está na busca pelo exótico, algo distante da situação narrada, mas que pelo próprio distanciamento revelaria o absurdo do real. No conto $O$ homem que sabia javanês, temos a história de um homem que, mesmo nada conhecendo da dita língua oriental, acaba figurando como o grande especialista no javanês, sendo escolhido como representante do país em congressos linguísticos. Nele, assim como nos contos argelinos, há um movimento que se configura como uma tendência para o exótico, que servirá de base para as sátiras. No caso de Anatole France, esta mesma tendência ao exotismo aparecerá no último volume da série, com os trublions, tornando-se estrutural na sátira dos pinguins.

É fundamental lembrarmos neste contexto do exótico, da figura do personagem caricaturizado que, ao contrário do herói intelectual, não é capaz de ter uma visão do todo, como é o caso do abade Guitrel, que o narrador revela ser incapaz de "découvrir les ridicules" (MO, 1987, p. 890). Ou, no caso de Barreto, do personagem de Xisto Beldroegas, “depositário das tradições contenciosas da Secretaria de Cultos", onde trabalhava Gonzaga. Beldroegas permanecia enfronhado na legislação e "não tinha uma idéia das suas origens e dos seus fins, não a ligava à vida total da sociedade." (GS, 1956, p. 144). Beldroegas é como a antípoda do narrador Augusto Machado, que parte da observação da vida para grandes reflexões, buscando compreender não somente o amigo Gonzaga, "fiz [..] tôdas as hipóteses, mas nunca nenhuma me satisfez" (p. 82), como a si mesmo, "durante meia hora, fiz um detido exame dos meus atos passados ..." (p. 40).

Assim como os trublions, que também não entendiam nada pela sua natureza avara que os havia "desnuez d'entendement" (MBP, 1991, p. 234). Esses homens de "petit sçavoir et entendement" se opõem aos intelectuais capazes, mesmo em menor número, de ter uma visão mais ampla dos acontecimentos e menos rígida das

${ }^{161}$ Em nota, Bancquart explica que muitos jovens buscavam os estudos que consideravam mais fáceis para reduzir o tempo de serviço militar e que a escola de línguas orientais era uma das mais em voga na época. 
transformações em curso. O éxotico e o caricatural nos parecem funcionar como pares na escrita satírica. $\mathrm{O}$ exótico descola a narrativa da intrincada relação entre personagem e meio, enquanto o caricatural nos parece ter uma função relevante na compreensão do tempo presente, na medida em que o caricaturizado não consegue ver o todo da situação, vivendo num eterno presente que se repete infinitamente.

No que diz respeito ao processo de caricaturização, é preciso desvendar, antes de tudo, quais são os personagens ficcionais e quais são os históricos no romance de France. Nos capítulos que tratam do complô dos nacionalistas, um movimento que corre em paralelo às reflexões e diálogos de Bergeret e no qual no narrador nos apresenta um grupo que equivale aos trublions, é possível visualizar esta mistura entre referências ficcionais e personagens históricos na trama romanceada do caso Dreyfus. De um lado, estão os nacionalistas ficcionais: a sra. de Bonmont, o barão judeu e antisemita Wallstein, o nobre sr. de Terremondre, os Gromance e o secretário da juventude monarquista, Joseph Lacrisse; de outro, os personagens históricos: o ministro Jules Méline $^{162}$, o presidente Félix Faure e seu sucessor Émile Loubet, que seria o responsável pelo o indulto concedido a Dreyfus depois de sua segunda condenação pelo tribunal militar.

Em geral, os personagens históricos aparecem mais durante as conversas de Bergeret, nas quais a ligação com a realidade é mais próxima. Como no diálogo com o marceneiro Roupart, por meio do qual o narrador ficcionaliza o debate entre os socialistas Jean Jaurès e Jules Guesde sobre a participação ou não dos socialistas no caso Dreyfus ${ }^{163}$. É no caso dos personagens ficcionais que a caricaturização aparece, pois eles sintetizam em uma só figura o comportamento de muitos homens.

Essa mistura de ficção e realidade também aparece em Gonzaga de Sá, na figura do Barão do Rio Branco, o Juca Paranhos, como o chamava Gonzaga, "uma mediocridade supimpa", segundo o narrador. O barão, que tinha como ideal de estadista "a solenidade cortesã das velhas monarquias européias" ou a "imponência de um cerimonial chinês" (GS, 1956, p. 70), representa, como os nacionalistas de Anatole France, o apego ao passado, e é marcado pelo exotismo na narrativa. Outro personagem

162 Méline foi contra a revisão do processo Dreyfus. Foi eleito presidente da Câmara de deputados, derrotando em 1888 Georges Clemenceau. Méline foi também primeiro ministro do governo de Félix Faure.

${ }^{163}$ No diálogo, há uma tomada de posição autoral por meio de Roupart em direção à posição defendida por Jaurès. France, como Roupart, acreditava que a defesa de uma injustiça, independente de se tratar de uma questão restrita à burguesia, era uma questão relevante para o pensamento socialista. 
caricaturizado e que se situa nessa mescla de realidade e ficção é o Barão de Inhangá, na verdade o Barão de Itaipu, vulgo Francisco Manuel das Chagas Dória, velho funcionário dos tempos do Império que "se fizera diretor e barão, graças ao seu nascimento e à sua antiguidade de funcionário" (p.79). Esse homem "inteligênte, mas vadio", nunca entendera nada do que realizava ali, e sua única atividade era fazer a todo instante a ponta do lápis, "em falta de qualquer mais útil aos interesses da pátria". No caso de Lima Barreto, portanto, é aos personagens reais que o exótico e o caricatural se aplicam com mais frequência.

\section{Os Trublions e a escola de Java}

O termo trublion aparece pela primeira vez em um artigo de 29 de novembro de $1898^{164}$, publicado no jornal L'Écho. Bancquart transcreve do artigo, a fala do personagem Bergeret que explica o significado do termo:

"Ce nom est celui d'une écuelle. Je trouve dans mon dictionnaire: 'Trublion, écuelle de bois et de fer-blanc, dans laquelle plusieurs matelots ou plusieurs soldats mangent ensemble'. Il y a là une allusion à quelque fait que j'ignore" (Bancquart, 1991, p. 1148).

A ignorância de Bergeret, claramente irônica, parte do pressuposto que o leitor contemporâneo a France leria na referência a alusão ao duque de Orléans, Philippe VIII, então chamado pela imprensa republicana de "prince Gamelle", depois de ter declarado que não pedia nada mais do que "la gamelle du soldat". Para não ser tão explícito na alusão, o narrador traduz o termo do francês para o grego: o termo trublion vem da palavra grega $\tau \rho v ́ \beta \lambda ı v$, “écuelle" em francês ${ }^{165}$. Trublion, tradução grega para o termo gamelle, é, portanto, uma alusão à monarquia francesa que buscava então, com o auxílio dos seus partidários, retomar o poder.

O termo aparece pela primeira vez na série Histoire, no oitavo capítulo do último volume, durante um diálogo no escritório de Bergeret, entre ele e seu aluno Goubin. A segunda referência aos trublions está no vigésimo sétimo capítulo, próximo à conclusão do romance, e trata do apaziguamento do grupo. Na primeira alusão, Bergeret lê para Goubin um longo trecho de um texto supostamente escrito em 1538 e encontrado na biblioteca de um amigo. Primeiramente, são nomeados os principais

\footnotetext{
${ }^{164}$ Essas informações estão no texto de Bancquart sobre o terceiro volume da série, L'Anneau d'améthyste. $\mathrm{O}$ artigo onde o termo aparece pela primeira vez não consta na série.

${ }^{165}$ Existe o termo "gamela" em português de Portugal com a definição de "escudela grande de pau ou de lata, onde se deitava antigamente o rancho dos soldados". Em português do Brasil, o termo significa uma vasilha de madeira ou barro que serve como recipiente para comida ou líquido.
} 
personagens do grupo dos trublions. O primeiro chefe Trublion "lequel estoit de haut lignage, mais de peu de sçavoir et en grande impéritie de jeunesse"166 e o segundo chefe Tintinnabule, grande orador, que havia sido expulso do país "par loi et usaige de ostracisme". Trublion e Tintinnabule estavam sempre em oposição e os seguidores, "étant si fols gens", não sabiam para que lado seguir. No trecho, aparece ainda o astuto Robin Mielleux, que desejava "gouverner la cité par le moyen de ces Trublions", e os atraia com uma doce voz "comme flûte, selon les guises de l'oyseleur qui va piper les oisillons" (MBP, 1991, p. 231).

A chave de decifração desses personagens é fornecida por Bancquart. O chefe Trublion, o pretendente ao posto de rei, é o próprio Philippe d'Orléans, o "prince Gamelle". Tintinnabule é o poeta nacionalista Paul Déroulède, fundador da Ligue des Patriotes em 1882 e banido da França por dez anos, por ter conduzido um complô contra a segurança de Estado, depois da prisão de nacionalistas, monarquistas e antissemitas em agosto de 1899. O trecho trata exatamente da desordem causada pelos trublions que mimetiza a ação dos nacionalistas ficcionalizada no romance a partir do décimo capítulo. Bancquart explica em nota que, em junho de 1899, as ligas da direita se manifestaram contra o então presidente Émile Loubet, que governou a França de 1899 a 1906, sucedendo a Félix Faure. Loubet, diferentemente de Faure, apoiava a revisão do processo de Dreyfus; por isso, a ira dos manifestantes antidreyfusards. O poeta Déroulède organizava manifestações semanais em Paris e foi um dos primeiros a subscrever a Liga dos patriotas - em oposição à Liga dos direitos dos homens, de 1898, que Anatole France foi um dos primeiros a aderir - e preparava então um golpe de Estado para ocorrer no mês de agosto, quando parte do grupo é preso ${ }^{167}$.

Temos nesse último romance da série duas narrativas que se complementam: a dos trublions, narrada por Bergeret, num processo de escrita de segundo grau ${ }^{168}$; e a história dos nacionalistas, misturando personagens ficcionais com personalidades reais. Nesse último romance da série Histoire, há um paralelismo entre uma narrativa em primeiro grau e uma narrativa em segundo grau, sendo que essas duas histórias se juntam nas associações feitas pelo narrador, principalmente na descrição do comportamento dos trublions e dos nacionalistas. A história dos trublions é, nesse

\footnotetext{
166 Nestas descrições encontram-se misturados o exótico, na referência a um tempo remoto; o caricatural, no rebaixamento cognitivo do outro; e o militante, na crítica disfarçada aos antidreyfusards.

${ }^{167}$ Ver mais detalhes em Bancquart (1991, p. 1252 e seq.).

${ }^{168}$ Esta compreensão da escrita em segundo grau está em Genette (1982).
} 
romance, um procedimento de satirização que corre em paralelo aos acontecimentos reais, que tendem ao caricatural, e às digressões e discussões de Bergeret.

$\mathrm{Na}$ relação entre a ficção e realidade, aparecem, portanto, duas camadas narrativas: a que traduz ficcionalmente os eventos reais, misturando personagens históricos e ficcionais, e a criação em paralelo de uma história aparentemente destacada da narrativa, mas que funciona como um espelho do real. No primeiro procedimento, é possível ver a semelhança com a construção ficcional dos personagens em Gonzaga de Sá e em Isaías Caminha, nos personagens caricaturizados inspirados em pessoas reais que faziam parte do universo do escritor Barreto, mesclados às figuras históricas da época. No caso da satirização dos trublions, há um dupla operação que só terá equivalente em Barreto nas sátiras e contos satíricos.

Voltando aos trublions. Depois dos dois personagens chefes, aparece Robin Mielleux, segundo Bancquart, uma referência a Jules Méline. Político cauteloso e antidreyfusard, é dele a frase "il n'y a pas d'affaire Dreyfus", proferida na Câmara dos deputados, à época do julgamento a portas fechadas do capitão Ferdinand Esterhazy, verdadeiro responsável pelo crime imputado a Dreyfus, mas absolvido pelo tribunal militar. Não somente o personagem mas também os acontecimentos fazem parte da história. Por exemplo, a alusão à voz suave como flauta de Méline remete a um discurso pronunciado por ele em abril de 1900 contra o então primeiro-ministro Pierre WaldeckRousseau, um dos responsáveis pelo início da reabilitação de Dreyfus. O que se observa, no geral, nessa primeira referência aos trublions é a redução do grupo à condição de estúpidos, ardilosos, burros e dissimulados, assim como o grupo dos nacionalistas é associado ao cachorro Riquet. Esse inimigo que grita e perturba é reduzido à condição de animal, enquanto dos homens (intelectuais) se espera um diálogo civilizado. A caricaturização destes personagens se encaminha para um processo de animalização, que será a base da sátira dos pinguins.

No segundo trecho dos trublions, durante o suposto apaziguamento desse grupo $^{169}$, a linguagem deles é descrita como adequada aos seus pensamentos; eles falavam de uma forma "très congrue et correspondant à leur pensée" (MBP, 1991, p. 340). Inclusive, durante todo o segundo trecho dos trublions, a força belicista do grupo está diretamente associada à sua incapacidade cognitiva, sendo o seu idioma o da

${ }^{169}$ No ano de 1900 ocorre a Exposição Universal em Paris. Em nota, Bancquart (1991)afirma que o apaziguarmento foi pedido pelos negociantes e a trégua instaurada pelo governo. Mas ela foi rompida dos dois lados, principalmente pelos nacionalistas. 
guerra, da ação, em detrimento da reflexão. Enquanto a linguagem do inimigo e das massas é pouco reflexiva, o sábio Bergeret recupera um texto do século XVI para tratar de seu tempo, emuma linguagem erudita, elevada, francamente oposta aos opositores belicistas. À guerra física, o narrador se defende com uma guerra de palavras, com o ataque e a redução dos inimigos a seres descerebrados. E essa redução se repete nos personagens nacionalistas: os trublions, “... crioient horriblement ” (MBP, 1991, p. 232) e o arquivista sr. Mazure, "avait poussé de grands cris en compagnie des royalistes et des cléricaux." (p. 236). Do lado dreyfusard, alguns personagens reais, Jean Psichari, Octave Mirbeau e Pierre Quillard, ao entrarem na prefeitura de Worms-Clavelin, "crurent entrer dans un ville du XVIe siècle" onde encontraram "des papistes idolâtres qui poussaient des cris de mort et les voulaient massacrer" (p. 237).

O procedimento de animalização, que antecipa a história dos pinguins, repete-se no capítulo em que Bergeret e Goubin discutem sobre a Exposição Universal de 1900. Nele, os personagens de Jean Coq e Jean Mouton representam a vertente nacionalista e xenófoba que se opõe ao poder da palavra de Bergeret com as suas onamatopéias "cocorico" e "bêe, bêe, bêe". Trata-se de mais uma narrativa de segundo grau, agora com uma característica mais fabulesca. Nela, Bergeret dá voz aos impulsos belicosos de Coq e Mouton, sem deixar de ironizá-los. A ironia do narrador aparece por exemplo na introdução de uma afirmação positiva no início dos parágrafos, seguida de uma explicação que se opõe à anterior. Por exemplo, Bergeret afirma que Coq e Mouton são republicanos, apesar de votarem no candidato imperialista ou monarquista, ou que Coq e Mouton não tem maldade, pois é "avec innocence qu'ils sont les ennemis du genre humain" (p. 307). A crítica se extende aos jornais, já que é a mentira destes diários que influencia os dois nacionalistas, "vous n'avez pas accumulé autant de mensonges, en une longue suite de siècles, que n'en assemble en un jour un seul des journaux que lisent Jean Coq et Jean Mouton” (p. 308). Essa denúncia da falsidade nos jornais não estaria na mesma linha da "fábrica de carapetões" de Isaías Caminha? Também esse processo de caricaturização, na atribuição de características animais aos personagens, não lembraria o personagem de Raul Gusmão, o João do Rio, "uma desencontrada mistura de porco e de símio adiantado", ou a "imensa cabeça de porco", de Aires d'Ávila, o redator-chefe do Correio da Manhã?

De fato, procedimento equivalente ao de France aparece no conto de Lima Barreto "Harakashy e as escolas de Java", no uso da negativa para mostrar a excentricidade do real das escolas de Java, particularmente no que diz respeito à 
literatura. O narrador afirma que a literatura de Java "não é uma atividade intelectual imposta ao indivíduo", mas sim "um jogo de prendas" (HS, 2008, p. 40). Também "não é fazer entrar no patrimônio do espírito humano [...] tudo o que interessa o uso da vida, a direção da conduta e o problema do destino" (p. 41- 42). Na sutileza de contar com a interpretação do leitor para flagrar a ironia, o narrador também começa a estabelecer uma distância entre o que é e o que deveria ser, sendo que para o real ele se utiliza da negativa como forma de enfatizar o "ideal”, aquilo que, na concepção do narrador, deveria ser o real.

A conversão do ironista em moralista se realiza, como comentamos anteriormente, na intenção do narrador em corrigir um mundo imperfeito, seguindo a afirmação de Bergson acerca do cômico: “du réel à l'idéal, de ce qui est à ce qui devrait être" (Bergson, 2010, p. 97). Essa moralidade do narrador, explicitada aqui por um procedimento de oposição entre o que não é o que deveria ser, opõe realidade e idealidade. A inversão do real na explicação da "boa literatura", aquela "constituída por vastas compilações de cousas de sua profisssão, escritas laboriosamente em um jargão enfadonho com fingimentos de língua arcaica" (HS, 2008, p. 42), revela o ideal na sua oposição. $\mathrm{O}$ absurdo da realidade só pode ser amplamente compreendido pela inversão do real. Mas, para qualquer perspectiva de transformação, é necessário também o vislumbre do ideal, daí a moralidade contida nesse tipo de procedimento.

Em Gonzaga de Sá, esse desejo corretivo se junta à denúncia social no encontro do narrador Augusto Machado com o grupo Esplendor dos Amanuenses - na verdade a mesma caracterização do grupo que Barreto frequentava no Café Papagaio ${ }^{170}$. Nesse grupo eram todos renovadores e pretendiam "reformar a moral e a literatura" (GS, 1956, p. 106). Um pouco à frente, ainda no mesmo parágrafo, depois da chegada de Gonzaga ao café, os dois amigos saem pelas ruas e o ímpeto reformador se dirige à observação de uns "graves homens de fisionomia triste, curvados ao pêso da vida" (p. 112). O narrador então compara essa visão a uma memória de infância quando vira uma longa fila de carros de bois pela estrada, e comenta: "Nem sabiam, aquêles animais, de sua fôrça". Quanto aos homens, afirma que, pacientes e tardos como os bois, "eram o esteio, a base, a grossa pedra alicerçal da sociedade", e que formavam "a trama de nossa vida social". (p. 113). A mensagem inicial de reformadores, juntamente com as observações dos trabalhadores como esteio da sociedade que viviam "sob o aguilhão dos deveres", dá à

\footnotetext{
${ }^{170}$ Ver Barbosa (2012, p. 139 e seq).
} 
narrativa um tom de denúncia social que se repete em muitos outros momentos da obra limabarretiana. É dessa mistura entre denúncia e função corretiva que a literatura militante se utiliza para denunciar e transformar a sociedade.

A denúncia é o objetivo central subjacente ao processo de caricaturização, realizada por essa moralidade irônica presente no exotismo dos trublions ou na literatura de Java. E é o uso da palavra, na articulação de sentidos encobertos, que realiza a "ação militante" da denúncia. De um lado, essa ação já nasce fracassada, pois o real se opõe ao ideal, que só existiria num mundo utópico. De outro, o mundo ideal permanece latente como possibilidade de futuro. O real fica assim cindido entre uma idealidade irrealizável e uma idealidade possível. A posição crítica de France (com os trublions) recorre a um tempo remoto, enquanto a crítica limabarretiana sempre remete a alguma referência espacial distante (Java, Argélia, Bruzundangas). A imagem utópica, como veremos, se divide entre uma escatologia messiânica, num tempo perfeito e uma utopia, no espaço perfeito.

\section{Idealidades possíveis}

Já mencionamos o trecho do romance Le Lys Rouge, citado por Barreto em 1904, no Diário Íntimo. Trata-se, como vimos de uma frase proferida pelo personagem Garain e, na cena, misturam-se personagens do mundo político francês, cujo governo estava envolto em constantes crises ministeriais e escândalos políticos. ${ }^{171} \mathrm{~A}$ fala de Garain é sobre as utopias e no trecho final (já citado), ele afirma: “as utopias aparentemente mais inofensivas exercem na realidade uma ação nociva. Elas tendem a inspirar uma aversão à realidade”. Em primeiro lugar, devemos levar em conta a apropriação de Barreto da opinião do personagem, que descreve a utopia como algo suspeito. Além disso, tomando como exemplo a Utopia de Augusto Machado em Gonzaga de Sá, temos o momento de esperança que transpareceu no desejo do narrador de construir a sua Utopia, a sua República, onde ele vê sobre a terra "dias de Bem, de Satisfação e Contentamento". Porém, o sonho rapidamente se dissolve e a desilusão

${ }^{171}$ Marie-Claire Bancquart lembra que o manuscrito do romance trazia muito mais elementos sobre a situação política da França, abandonados em prol da história de amor: "Le manuscrit de celui-ci est plus direct encore dans la dénonciation du pouvoir contemporain. Il fait allusion au scandale de Panamá; il explique plus au long les combinaisons para lesquelles Montessuy fabrique les ministères; il prête aux responsables des propôs plus cyniques. Sans doute ces indications furent-elles abandonnées pour garder au Lys rouge son caractère de roman essentiellemet amoureux, la politique n'y paraissant que pour marquer le caractère en quelque sorte incongru et exceptionnel d'une passion à l'état pur dans un pareil monde." (Bancquart, 1987, p. 1210). 
toma conta do narrador que conclui "morto um preconceito ou uma superstição, nasciam outros" (GS, 1956, p. 141). O "reino feliz", sonhado na utopia de Machado, só poderia surgir se as "noções entibiadoras" da Arte, Ciência e Religião estivessem mortas, os cânones esquecidos, assim como seus delírios e preceitos. Inviáveis, portanto, as condições da felicidade, fica a conclusão do cético narrador de que "sábio era não agir". No espaço presente, portanto, a utopia limabarretiana converte-se, em função da ironia do narrador, em impossibilidade, em idealidade irrealizável.

Vejamos o procedimento. Em primeiro lugar, temos a associação da Utopia à República. Em segundo lugar, temos as noções enganadoras: a Arte, a Ciência e a Religião. Ao que parece, o narrador, ao usar a letra maiúscula nesses termos, refere-se àquilo que é oficial, acadêmico: a arte reconhecida pelas Academias, a ciência feita nas Universidades, a religião católica e oficial. Diante das desilusões do real, porém, o narrador chega à máxima de que o sábio era não agir, a mesma do árabe anatoliano que aparece em Numa e a Ninfa, para quem a palavra tem um efeito desastroso no futuro. Da mesma maneira que a concepção temporal, a utopia de Lima Barreto apresenta-se inviável no tempo presente estagnado, enquanto a ação nociva da utopia anatoliana projeta um efeito pernicioso futuro, um vislumbre da perspectiva catastrófica da sátira dos pinguins.

Essa perspectiva catastrófica é uma das imagens do desejo utópico segundo Martin Buber (2007), que examina alguns aspectos do "socialismo utópico", denominação atribuída posteriormente à época do surgimento das teorias e práticas hoje conhecidas sob essa alcunha. Segundo o autor, essa denominação vem de uma oposição que se inicia a partir da publicação do Manifesto Comunista, de 1848, na referência de Karl Marx a Pierre-Joseph Proudhon, como um dos "socialistas burgueses". Buber ressalta, porém, que Engels, alguns anos antes do Manifesto, considerava-os os "fundadores do socialismo", mesmo porque, a ideia de utopia não deixa de estar presente na própria perspectiva marxista, ainda que num período pós-revolucionário. É essa, de fato, a grande diferença entre os primeiros utópicos e os marxistas. Se para estes, a revolução é condição inicial da transformação, para aqueles, a mudança deve ocorrer a partir das condições reais, na edificação e planejamento com o fim de reestruturar a sociedade. Buber discrimina as contribuições dos primeiros utópicos: a discussão entre estado e indivíduo em Saint-Simon, os falanstérios de Charles Fourier, a doutrina como resultado da experiência em Robert Owen, o anticentralismo de 
Proudhon, a perspectiva historicizada de Piotr Kropotkin e as três etapas da revolução política à social de Gustav Landauer. Além disso, Buber trata também dos movimentos cooperativistas entre 1830 e 1848 na França e na Inglaterra.

Buscando conceber um conceito de utopia, Buber pensa a imagem utópica como "um quadro do que "deve ser", quadro este que não pode estar separado de uma "atitude crítica em face da atual maneira de ser do mundo humano" (Buber, 2007, p. 18). Desse quadro do que "deve ser" e da atitude crítica frente à realidade, é que surgiria o desejo utópico, a visão do justo que se efetiva ou na imagem de "um tempo perfeito, como escatologia messiânica", ou de um "espaço perfeito, como utopia". A escatologia, doutrina que trata do destino final do homem e do mundo, pode se apresentar como discurso profético ou em contexto apocalíptico. Já a utopia pode ser tanto o lugar ou estado ideal de felicidade e harmonia entre os indivíduos, ou a descrição imaginativa dessa sociedade, com leis justas e instituições comprometidas com o bem-estar comum. A positividade da utopia, segundo Buber, é que ela permanece no âmbito da sociedade, destacando-se somente geograficamente ${ }^{172}$, enquanto a escatologia transcende o aspecto social na sua imagem destacada do tempo da experiência.

O narrador Augusto Machado fala de sua utopia a partir das observações da "festa nacional", mais especificamente a partir da discrepância social entre os "dourados almirantes" e da conversa dos "dois populares" que discutiam "com evidente orgulho", o desfile do exército. Dessa situação para o vislumbre de "dias de Bem, de Satisfação e Contentamento", o narrador ascende "a tôdas as injustiças" e colhe "todos os males que nos cobriam os conceitos e preconceitos", desejando erguer ali a sua Utopia e a sua República. Na cidade em que vive, o narrador empreende o esforço utópico de pensar num estado ideal de felicidade e harmonia entre os homens na sua República. Esforço inócuo, como sabemos. Já a utopia do narrador do sr. Bergeret é antes, uma descrição imaginativa dessa sociedade que não se realiza hoje, mas em um futuro, esse, como se lê em Le Lys Rouge, desastroso. A imagem utópica do narrador anatoliano se efetiva destacada da sociedade, construída somente pela palavra literária, seja num contexto mais catastrófico das palavras de Garain, seja como discurso profético de Bergeret.

De qualquer forma, nenhuma das utopias parece irrealizável, fundamentalmente,

172 Christiane Zschirnt, em Livros: tudo o que você não pode deixar de ler, citada por Buber, distingue as primeiras utopias, dos séculos XVI e XVII, passadas em lugares inexplorados - ligadas ao contexto de colonização - das utopias modernas (ou distopias), dos séculos XIX e XX, que ocorrem num tempo futuro, vinculadas aos projetos revolucionários. 
em função da recusa da ação - espaço ocupado pela palavra militante. A literatura militante que Barreto vê em France traz essa abertura potencial na obra ficcional para o poder transformador da palavra, abertura deixada pela inação dos personagens. $O$ “escopo sociológico" de France está ligado não somente a esse ato da palavra, mas também ao viés corretivo dos personagens do mundo ficcional, que não buscam na ação a transformação, mas no poder de reflexão. Como já vimos, a ação propriamente dita cabe aos nacionalistas, como expressa Joseph Lacrisse no seu horror ao ceticismo: "J'ai horreur du scepticisme. C'est la négation de l'action. Moi, je suis pour l'action, toujours et quand même" (MBP, 1991, p. 311). Ou no elogio ao "entraînement", método de luta descrito pelo aluno de Jacques de Cadde, um dos trublions, criador da subscrição em apoio ao tenente-coronel Henry ${ }^{173}$, método no qual o homem se vê determinado a agir.

De um lado, portanto, as perspectivas de France e Barreto em relação à utopia estão descoladas da ação ${ }^{174}$, são antirrevolucionárias. Parecem-nos, portanto, pensadas a partir de uma premissa ligada aos socialistas utópicos. A cidade ideal de Bergeret se apresenta destacada da situação romanesca, sendo pensada num tempo futuro, como os projetos utópicos difundidos à época, de Saint-Simon, Fourier, Proudhon, Kropotkin, dentre outros. No caso do narrador Machado, o seu projeto se ancora na sua realidade mais próxima, no seu tempo, mas só seria passível de concretude com o fím das noções entibiadoras. Para ocorrer, seria necessário superar a realidade presente num longo caminho para religar a humanidade.

No caso do narrador anatoliano, são dois os momentos em que aparecem visões utópicas do futuro: na cidade ideal que o professor Bergeret descreve para a sua filha Pauline e no mundo futuro visitado em sonho no romance Sur la Pierre Blanche (PB), de $1905^{175}$. Na cidade ideal de Bergeret, a descrição do trajeto chama a atenção, como já vimos, pela ironia ácida do narrador. De um lado, temos a posição de candelabro que confere uma qualidade de objeto de decoração ao mendigo; de outro, observamos a sacralização da rua, que remete criticamente ao anticlerical Anatole France. Estes dois

\footnotetext{
${ }^{173}$ O tenente-coronel Henry foi condenado pela falsificação de documentos do caso Dreyfus e se suicidou na prisão.

${ }^{174}$ Segundo Buber, somente no socialismo moderno o entrelaçamento entre projeto e experiência se realiza, particularmente na doutrina marxista e nas revoluções do início do século XX.

${ }^{175}$ A pré-história desse romance vai desde os primeiros capítulos publicados ainda sob o título de Histoire Contemporaine, em 1900, até a edição original de 1905. Passa pela viagem de France à Itália em 1903, por uma primeira edição com notas neste mesmo ano, por alguns capítulos publicados no suplemento ilustrado do New York Herald Tribune também em 1903 e outros no L'humanité em 1904. Ver Bancquart (1991, p. 1458 e seq.).
} 
elementos dão à cena um tom de estagnação, de algo cristalizado. Além disso, ao metaforizar a cena na rua, o narrador, ironicamente, a "embeleza", transformando a degradação em celebração.

Esta cena dá ensejo a longas divagações de Bergeret que se iniciam com uma autocrítica pela ação da esmola ao mendigo Clopinel. Mas, na verdade, o que chama a atenção é a própria nomeação do mendigo, o que certamente não é fortuito, pois trata-se de uma alusão ao poeta medieval Jean de Meung, batizado como Jean Clopinel, satirista e crítico das ordens mendicantes da igreja. Assim como em outros momentos da obra de France, nesta nomeação, é possível ver dois procedimentos: a inclusão sutil de um elemento textual que abrange a referência satírica, e uma associação entre passado medieval e satírico e o tempo presente do capitalismo. Esta associação aparece na frase do próprio Bergeret, quando ele fala da sua ação sobre Clopinel: “... je t'ai fait capitaliste avec ironie et convié sans honneur au banquet de la société, aux fêtes de la civilisation" (MBP, 1991, p. 287). No simples comentário ao ato da esmola, o narrador introduz a referência satírica e retoma sua concepção de tempo cíclico ao associar o passado medieval ao capitalismo do mundo civilizado.

É essa alusão ao sistema econômico que dá o gancho para a explanação da visão de sociedade futura de Bergeret à sua filha, a qual deverá ser construída pela força das palavras e na qual “... chacun jouira du fruit de son travail” (p. 290). Apesar do projeto utópico, o personagem Bergeret comenta que esse tempo estaria longe de se tornar realidade, porém, estaria a caminho com a redução da miséria e o progresso da indústria; ambos deveriam amenizar a violência e a barbárie originais do homem em luta pelos bens necessários à sobrevivência.

É na segunda parte desse longo trecho do percurso de Bergeret e Pauline ${ }^{176}$ que o professor descreve efetivamente a sua cidade ideal. Nela, o "mal moral et physique", inevitáveis aos homens, não seriam acrescidos dos "maux artificiels qui résultent de notre condition sociale" (p. 290). A mudança viria da máquina, "d'abord cruelle et dure, deviendra bonne, favorable, amie". A forma desta transformação, porém, é trazida para o campo da poesia, para a figura do desconhecido: essa "force mystérieuse et captive" auxiliaria, por meio da eletricidade, "dans les maisons, dans les chambres, au foyer où le père et la mère et les enfants ne seront plus séparés" (MBP, 1991, p. 291). Porém, nem a

\footnotetext{
${ }^{176} \mathrm{Na}$ cronologia de publicação no jornal, a primeira parte do trecho é publicada no dia 3 de janeiro de 1900 e a segunda sete dias depois.
} 
força desconhecida da máquina e o fim do trabalho iníquo seriam suficientes para "un changement plus merveilleux". Para isso, o patrão "s'élevant en beauté morale", deveria se tornar também um trabalhador, num ambiente onde não haveria mais salários, mas troca de bens. Também não há aqui qualquer alusão a maneira como deveria se dar essa transformação.

Bergeret assume o caráter ideal de sua cidade, mas lembra que são os sonhos dos filósofos que estimularam os homens de ação a colocar o projeto em prática, e que é o pensamento que “crée l'avenir" (p. 293). Caberia então, à palavra, a construção dessa nova ordem social, essa arma invisível que "abat les violents et fait tomber les forts" (p. 294). Ele mesmo acredita que não verá a nova cidade, pois como as transformações naturais, as sociais levam um longo tempo, mas acontecem "insensiblement et sans cesse" (p. 294). Estamos na esfera dos socialistas utópicos, nesta visão de mundo que deve se realizar no futuro, mas que já encontra suas bases no presente. A peculiaridade do mundo futuro de Bergeret é o papel da palavra como força transformadora.

Em Gonzaga de Sá, apesar do tom cético e pessimista de toda a narrativa, há um trecho em que aparece brevemente uma esperança de mudança social. Ao falar de sua amada cidade, Gonzaga vê no bonde - um equivalente da máquina anatoliana - o veículo de aproximação entre pobres e ricos, nesta cidade cujo relevo dificulta a aproximação. Esse veículo que "alastra a cidade" e serve para "fazer o rico morar num bairro pobre e o pobre morar num bairro rico" permitiria a mistura das estratificações, sendo que "a divisão da riqueza e novas instituições sociais ajudariam o bonde nesse trabalho plutônico" (GS, 1956, p. 67). Enquanto o mal seria o isolamento entre pobres e ricos, como os males artificiais que são resultado da condição social em France, a "penetração mútua" da máquina seria capaz de sanar o isolamento que a cidade impunha.

Ainda que o narrador limabarretiano parta de uma construção ideal calcada no real, também aqui não há uma expressão clara da forma como se dariam essas transformações nas cidades. Assim como em France, a transformação é gradual e a sua finalização só será realizada no futuro, quando "o aperfeiçoamento da viação sanará tudo isso". Parece contraditório o fato de que o mesmo progresso que desconfigura as cidades do Rio de Janeiro e Paris, seja também o propulsor de transformações sociais, o elemento de ligação entre pobres e ricos. Mas, essa contradição só existe para o observador de hoje. Ela tem foros diferenciados, a cidade desfigurada lida com a 
interioridade e as transformações sociais com a militância literária. Afinal, a postura crítica e inconformada com a situação real de desigualdade não poderia se isentar de um projeto pautado pela transformação, de correção do real pelo ideal.

O espaço do subúrbio talvez seja o único em Gonzaga de Sá, no qual persiste alguma positividade. Neste espaço entre a cidade e a roça, o narrador Augusto Machado segue o aspecto sinuoso das pequenas ruas, do que foi perdido nas transformações da cidade, onde ainda é possível encontrar o "arruamento delirante", onde uma rua larga e ampla "de repente estrangula-se, bifurca-se, subdivide-se ...”. Misturam-se aí o capinzal, a "casinha acaçapada", a velha casa senhorial de fazenda e as novas edificações burguesas. É o espaço no qual "as épocas se misturam" e onde o tempo passado convive harmonicamente com o presente. Ali se encontram "um velho 'pouso' dos tempos das cangalhas", as "bamboleantes casas roceiras", assim como "um palacete estilo Botafogo" (GS, 1956, p. 114). Enquanto a cidade de Gonzaga está marcada somente por um tempo passado, dissolvido, que ele busca a todo custo reviver no presente, o subúrbio do narrador Augusto Machado representa uma espécie de síntese temporal, na qual as transformações da cidade dão lugar a um universo situado a meio caminho entre a cidade e o campo e que condensa todas as épocas nas suas formas.

A relação entre a cidade e o campo na literatura inglesa foi objeto de estudo de Raymond Williams. Segundo Williams (2011), a despeito da variedade histórica dos conceitos "campo" e "cidade", cristalizaram-se, com o tempo, atitudes emocionais em relação a eles, tanto positivas como negativas. Dentre os inúmeros autores e imagens estudadas em relação às formas como esses dois universos foram pensados pela literatura, William examina como nasceu, da vivência nas cidades, uma vivência do futuro, a partir de modelos tradicionais de uma vida além da morte, passando pelo mito das novas terras descobertas, até o vislumbre de transformação coletiva no seio mesmo das metrópoles.

Segundo Williams, escritores como William Morris e H.G.Wells, de formas distintas, "utilizam a nova experiência coletiva que é o produto social da experiência urbana, mesmo quando seu impulso é no sentido da crítica e da rejeição" (Williams, 2001, p. 446). Em News from nowhere (1890), de Morris, o protagonista acorda e se vê na Londres do século XXI. Muito semelhante, ainda que em sonho, é a visão que o personagem Hippolyte Dufresne, no livro Sur la Pierre Blanche, de France, tem do ano de 2270, "l'an 220 de la fédération des peuples de l'Europe”. O próprio Dufresne cita 
Wells e Morris: “Je n'ai pas conduit la machine par laquelle M. H.-G. Wells explore le temps. Et si c'est en dormant, à l'exemple de William Morris, que j'ai sauté trois siècles et demi ...” (PB, 1991, p. 1103). Williams observa, enfim, que os sentimentos e ideias sociais que criaram a cidade de Morris estavam em sintonia com o movimento socialista da época.

No Brasil, palco das idealizações idílicas da colonização, a metrópole é ainda uma exceção num país predominantemente agrário ${ }^{177}$. Ainda assim, as mudanças no Rio de Janeiro, na passagem para o século XX, acabaram formando um tipo de consciência nova, característica das metrópoles, como observa José Murilo de Carvalho (1987). As expectativas despertadas com a proclamação da República deram um novo dinamismo à capital com a entrada, na cena política, de grupos como os militares, os operários, os funcionários públicos, os pequenos proprietários, os jacobinos, etc. Segundo Carvalho, somente os capoeiras - malandros típicos do século XIX carioca - e os anarquistas não tiveram qualquer tolerância e foram constantemente reprimidos pela República. Carvalho ressalta ainda a movimentação no mundo das ideias e mentalidades com a República, parafraseando Sérgio Porto, um "maxixe do republicano doido". Nele, “misturavam-se, sem muita preocupação lógica ou substantiva, várias vertentes do pensamento europeu" (Carvalho, 1987, p. 24). ${ }^{178}$

Aos poucos, a República do Brasil deixa de ser eminentemente carioca com a mudança de eixo do governo central. O intuito, segundo Carvalho, era conter as numerosas revoltas populares e militares, com a neutralização da capital e a transferência do poder para os estados, cooptando suas oligarquias. A expectativa inicial com a República foi sendo "sistematicamente frustrada", segundo o historiador, com o desapontamento dos intelectuais depois da fase de perseguição de Floriano Peixoto. O resultado foi a restrição dos intelectuais ao universo literário, a cisão dos operários entre

${ }^{177}$ Segundo Milton Santos (2008), o fenômeno de urbanização encontra uma primeira aceleração no final do século XIX, porém, como os dados são bastantes frágeis até o recenseamento de 1940, muitas das informações se contradizem. Ainda assim, em 1872, Santos enumera três capitais brasileiras com mais de 100 mil habitantes e uma com mais de 50, enquanto que em 1900, havia quatro cidades com mais de 100 mil habitantes (com mais uma beirando esse número), e cinco capitais com mais de 50 mil habitantes.

178 Um dos eventos políticos mais importantes da época, a abolição da escravatura, teve influência direta na formação de Lima Barreto, segundo Carvalho, que lembra a aversão do escritor em relação à República. Barreto vira ainda criança as comemorações da abolição e as festas com o regresso do imperador no mesmo ano, ao mesmo tempo em que presenciaria a demissão do pai da Tipografia Nacional pela política republicana. Não é à toa que a sátira escrita nos últimos anos da vida de Barreto trata da República dos Bruzundangas. 
anarquistas e cooptados pelo Estado e o desaparecimento dos jacobinos. É nesse contexto que Carvalho vê o aparecimento dos criminosos da cena política, bem retratados pelo personagem de Lucrécio Barba de Bode, em Numa e a Ninfa.

Essa breve digressão histórica serve para mostrar a peculiaridade do Brasil no que diz respeito à viabilidade das utopias dentro do nosso contexto urbano e republicano. É certo que visões de um futuro utópico figuram em romances que se passam ou se findam no campo, como é o caso do $O$ ideólogo, de Fábio Luz ou de Regeneração, de Curvelo de Mendonça. Já a cidade que Barreto nos apresenta tem rompantes de um futuro ditoso, mas se revela cindida, já que, de um lado, não há ação, de outro, a palavra desse narrador não encontra grande ressonância. A cidade republicana de Augusto Machado é também um espaço da antiutopia. Carvalho vê a nossa primeira República num impasse, tendo de um lado, o liberalismo "como instrumento de consolidação do poder, desvinculado da preocupação de ampliação das bases deste poder"; de outro, essas demandas de ampliação foram reformuladas ou na "perspectiva integradora do positivismo", ou na "fuga romântica do anarquismo", ou ainda no "radicalismo republicano de estilo rousseauniano" (Carvalho, 1987, p. 65). Não havia como pensar numa cidade ideal nessa República que oscilava, segundo Carvalho, "entre a negação da participação, a participação autoritária e a alienação". Qualquer possibilidade de transformação estrutural também parecia irreal ao cético Augusto Machado. Ainda assim, a cidade permanece viva como espaço de transformação possível nos subúrbios, equivalente do campo libertário na literatura limabarretiana, e o bonde em movimento permite o vislumbre, ainda que frágil, de uma possível integração.

Bergeret, por outro lado, no último romance da série Histoire, vivia a euforia dos dreyfusards com as mudanças de rumo no caso, particularmente depois da morte do presidente Félix Faure. Num contexto mais amplo da obra de France, porém, Bancquart observa que o otimismo de Bergeret se converte em pessimismo em Sur la Pierre Blanche. Se Bergeret acreditava que "il est permis de bâtir en Utopie" (MBP, 1991, p. 293), a preocupação do autor com os movimentos belicosos na Europa, que já aparece nas figuras de Jean Mouton e Jean Coq, acrescenta um tom mais cético às utopias futuristas do dreyfusard Bergeret. Alguns textos publicados na coluna Histoire Contemporaine, em Le Figaro, e não incluídas no volume da série, já marcam essa mudança de tom. Trata-se de uma série de seis textos com o título Prophéties, 
publicados no jornal de agosto a setembro de 1900, nos quais Bergeret discute com discípulos e amigos sobre a paz universal e o futuro. $\mathrm{O}$ digressivo professor retoma nessa discussão os nacionalistas, os trublions, a divisão socialista entre Jaurès e Guesde, além de introduzir o personagem Gallion, um sábio grego.

Ao final dessa série, Bergeret conclui que somente os loucos têm ideias produtivas e só eles são capazes de mudar o destino dos homens, e define os loucos como "ceux qui pensent par eux-mêmes, et qui n'ont pas que les idées communes" (MBP, 1991, p. 483). Já em Sur la Pierre Blanche, não é possível encontrar nenhuma declaração comparável às de Bergeret. Os tempos felizes que Bergeret previra são desmentidos pela realidade: os dreyfusards se separaram, o embate entre os socialistas permanece, a guerra começa a surgir em diversos pontos do mundo e a possibilidade de uma paz universal se torna cada vez mais remota.

É nesta visão desapontada que os dois narradores voltam a se assemelhar, no desencanto face ao presente. E é nesse sentido que a experiência da cidade oscila entre um saudosismo e um ceticismo diante do futuro. Assim como o personagem de Gonzaga de Sá permite que o narrador internalize tempos remotos, em Pierre Nozière, o personagem do livreiro, o sr. Louis-François Debas, permite que o narrador anatoliano trate da mudança na cidade, saudoso das antigas paisagens. No caso de Gonzaga de Sá, o narrador Augusto Machado opõe a cidade de Petrópolis, como o espaço sem história e com pouca fantasia, de "estrangeiros invasores" e sem cultura, à cidade de Gonzaga, que representa o "Rio de Janeiro, com seus tamoios, seus negros, seus mulatos, seus cafuzos e seus 'galegos' também ...” (GS, 1956, p. 59).

O narrador internaliza esse passado de Gonzaga depois de jantar na casa do amigo e de sua tia Dona Escolástica, ao descer a ladeira com "a percepção nítida dos sentimentos e das idéias das gerações que me precederam”, e sentindo-se mais firme "contra as pressões externas", como se tivesse absorvido "uma gôta de veneno". Depois do contato com Gonzaga, Machado conclui, olhando o Passeio Público, que "tinha mastigado idéias ...”. (GS, 1956, p. 102). Essa experiência da cidade por Machado se opõe, no romance, à de Juca Paranhos que "faz do Rio de Janeiro a sua chácara ...", mas não compreende a cidade, apenas a domina, distribuindo o dinheiro do Tesouro, governando ao lado da corrupção, saltando por cima das leis e figurando como personagem teatral. Ao seu desejo de dominação, opõe-se a experiência participativa da vida das pessoas comuns por Machado. 
O sr. Debas, personagem do romance Pierre Nozière, esse "bouquiniste de pierre" que "ressemblait à ces statues de pierre que le temps ronge sous les proches des églises", nos parece ser uma das fontes da experiência do narrador na cidade de Paris, onde ele "entend les pierres conter une des plus belles aventures humaines, l'histoire de la France ancienne et de la France moderne". (PN, 1991, p. 525). Como muitos personagens nas narrativas anatolianas, Debas é também um humanista que "pratiquait tous les arts pour l'amour des hommes" (p. 529), e tinha como grande ocupação velar sobre a coisa pública. O narrador projeta um futuro nada promissor: "Peut-être que, chassés des quais, les bouqinistes n'y reviendront plus et que leurs étalages seront la rançon du progrès" (p. 531). Esse personagem do passado, o reverso do progresso e do futuro, também enriquece a experiência do narrador que, no futuro, se recordará das horas de prazer passadas diante desses cubículos à margem do Sena, "enrichi de pourpre et d'or, ou seulement gris, mais d'un gris si doux qu'on en est ému jusqu'au fond du coeur" (p. 531). O passado marcado pela figura do sr. Debas aparece aqui como uma espécie de resistência ao progresso e às transformações na cidade, dessa Paris bouleversée diante da iminência da Exposição Universal de 1900, assim como Gonzaga de Sá.

Também a experiência do sr. Bergeret confirma a sensação de abandono diante da cidade modificada: "J'ai perdu mes amis, et voici que tout ce qui me plaisait dans cette ville, sa paix, sa grâce et sa beauté, ses antiques élégances, son noble paysage historique, est emporté violemment" (MBP, 1991, p. 205) ${ }^{179}$. Já vimos, porém, que o personagem de Bergeret oscila entre o saudosista e o esperançoso que constrói a imagem da cidade ideal inspirada no modelo dos socialistas utópicos. Ainda assim, a sensação de desterro permanece nesse último livro da série Histoire, na mudança de Bergeret para uma Paris desfigurada pela haussmanization e na sua busca de um lar.

Esse homem desterrado ${ }^{180}$ que busca o passado para completar uma experiência e que não pode se realizar em decorrência da desfiguração da cidade, é também um homem desiludido com o futuro, pois, ou participa do "cenário humilde dos apartados

${ }^{179}$ Segundo nota, em 19 de novembro de 1899, pouco antes da publicação desse artigo depois incluído no romance, foi inaugurado o monumento "Le Triomphe de la République", na praça da Nação. As delegações dos operários assistem à inauguração usando um "drapeau rouge" e os dreyfusards favoráveis aos socialistas celebram a manifestação que parecia, segundo Bancquart, "prophétizer un profond changement social"'.

${ }^{180}$ Dentre as muitas definições do romance em Teoria do Romance, Lukács diz que o romance é a "expressão do desabrigo transcendental” (Lukács, 2000, p. 38). 
do progresso", como é o caso do narrador limabarretiano, ou percebe, como observador rigoroso que "la société repose sur la résignation des pauvres" (MBP, 1991, p. 222). De um lado, temos, portanto, narradores que, em sintonia com as ideias de seus respectivos tempos, reproduzem as esperanças futuras em um mundo mais justo e igualitário. De outro, temos os loucos "qui pensent par eux-mêmes" e que observam, racionalmente, as limitações destes projetos utópicos. A cidade republicana é, assim, o espaço da idealidade irrealizável e da idealidade possível diante da contraditória relação destes narradores com o seu tempo.

De um lado, o progresso atua como força destrutiva, na medida em que as transformações destroem o passado e a história. De outro, o progresso promete um outro futuro possível inspirado nas ideias sociais correntes. De qualquer maneira, o presente inspira no herói uma sensação de desamparo e inércia, e a palavra é a sua única forma de ação possível. O espaço, para onde a ação foi transferida, está destruído. Por isso, nos caminhos traçados nas obras de Barreto e France, o abalo da mímese, que é parte importante da literatura militante, requisita outro tom para a narrativa. E uma possibilidade é o método criativo da sátira. Isaías se associou ao satírico Gregoróvitch, Bergeret lançou mão de alegorias e caricaturas para descrever o real, Gonzaga viu a sua utopia destruída na cidade e o criador de Crainquebille questionou a representatividade do herói intelectual.

No conto ${ }^{181}$ homônimo, o vendedor de legumes Crainquebille é preso por ter supostamente desobedecido e insultado um policial. Na verdade, o que acontecera é que aguardando o pagamento da sapateira que lhe havia levado alguns legumes sem pagar pela compra, o policial ordena a evacuação da rua em função do movimento dos veículos. Crainquebille se vê impedido de sair dali e o policial, equivocadamente, o prende por desacato. Durante a discussão, um velho sábio que acompanhava os acontecimentos intercede a favor de Crainquebille, porém, sem sucesso. Crainquebille é então condenado a duas semanas de reclusão, porém, quando sai, não consegue mais vender seus produtos e cai na completa miséria. Tenta inutilmente ser preso novamente,

${ }^{181}$ Crainquebille é publicado em 1900 nas crônicas de Le Figaro e em 1902 aparece no Cahiers de la Quinzaine. A edição original pela Calmann-Lévy, Crainquebille, Putois, Riquet et plusieurs autres récits profitables, sai em 1904. O conto foi transformado em peça teatral por France com a ajuda de Lucien Guitry, sendo publicada em maio de 1903. Há também um filme mudo de 1922, de Jacques Feyder, disponível na internet (http://www.youtube.com/watch?v=x2f0T1G60DY). Ver Bancquart (1991, p. 1375). 
mas o seu fim é triste e miserável. Um aspecto é fundamental nesse conto social ${ }^{182}$ : o ponto de vista do narrador ressalta o desamparo do personagem e a impossibilidade de representação pelo intelectual, pois "les savants étaient suspects". (Cr, 1991, p. 729). Ainda não estamos lidando com o desencanto do criador da sátira dos pinguins, mas os sinais nos parecem claros.

Enfim, na ausência da ação e com um herói que não consegue mais falar pelo outro ou por si próprio - pensando aqui também no fracasso da proposição do tupi como língua nacional por Policarpo Quaresma -, a literatura militante tende a ir em três direções: em primeiro lugar, para textos de menor fôlego como as crônicas, nos quais a relação com o real é bem próxima; em segundo lugar, para uma linha mais autobiográfica ou alegórica ${ }^{183}$; e por fím, para a narrativa satírica, como é o caso de L'Île des Pingouins, e de Os Bruzundangas, sátiras que reconstituem a história e as características de seus respectivos países em um ponto distante. O moralismo irônico desses dois escritores, cujos narradores buscam corrigir a realidade pela força da palavra, parece ter encontrado o limite da representação pela palavra, seja na presença da loucura em Barreto, seja diante da guerra iminente na Europa, tão temida por France. Nessas situações de crise, resta a representação pelo método criativo da sátira, que tem como pressuposto ideológico "o ódio e a indignação em face de um estado social justamente condenado à morte" (Lukács, 2009, p. 183). Passemos então a elas.

${ }^{182}$ Essa é a caracterização dada por Oswald de Andrade (ver introdução).

${ }^{183}$ No caso de Anatole France, é possível pensar em La Révolte des Anges, na simbólica guerra entre céu e terra e na inversão do papel dos anjos. Também é possível pensar no romance histórico Les Dieux ont soif, que também figura como um caminho possível no mesmo gênero romance. 


\section{Parte 3: Modo Satírico}

“L’ironie est la dernière phase de la désillusion” (A. France)

“A ironia vem da dor” (Lima Barreto)

“A Sátira é uma espécie de Espelho, onde em geral Quem se olha descobre o Rosto de todos, menos o Seu; o que é a principal Razão para a boa Acolhida com que o Mundo a recebe, e para que tão poucos sejam ofendidos por ela." (Jonathan Swift) 


\section{O Satírico}

Enquanto nos romances da série Histoire Contemporaine ou em Isaías Caminha e Gonzaga de Sá, a realidade foi filtrada pela visão do herói intelectual e pelo processo de caricaturização dos coadjuvantes da narrativa, no caso das sátiras, a caricatura é o ponto de partida para a construção do mundo imaginário. Talvez, o longo processo de maturação da escritura das obras tenha influenciado a composição da sátira, pois, ainda que obedecendo à mesma lógica da coletânea de crônicas publicadas em revistas ou jornais e depois reunidas em livros, sua elaboração se deu num espaço de tempo estendido: no caso de L'Île des pingouins, de 1905 a 1908, e no caso de Os Bruzundangas, algumas poucas crônicas já aparecem em 1911, mas grande parte foi publicada entre 1917 e 1918. O paratexto prefacial, por sua vez, continua a funcionar como espaço de poética, por vezes moralizador e num tom um tanto mais cômico do que nos romances. Nesta poética satírica, assim como nos romans à clef, a chave dos personagens satirizados é fundamental para um exame crítico da obra, seja na figura dos ministros do governo Venceslau Brás, seja nos personagens pinguins que alegorizam o caso Dreyfus.

No trânsito entre o mundo ficcional e o real é que o discurso satírico se torna mais instigante. Para o seu exame, uma das chaves principais de elucidação está na relação com outras crônicas ou textos de intervenção. Porém, diferentemente dos textos publicados na imprensa, nas sátiras, as fronteiras entre o ficcional e o real são ao mesmo tempo claras e nebulosas, e assim devem ser para que produzam, no leitor, uma desconfiança permanente na ligação entre o evento narrado (sendo o evento um personagem, um acontecimento ou uma situação) e o real. Enquanto, de um lado, as crônicas e textos de intervenção falam mais diretamente ao leitor, no caso das crônicas reunidas nas sátiras, o real se torna mais opaco. Este elemento é uma das chaves do método satírico que, para ressaltar o absurdo do real, abstém-se da verossimilhança esperada pelo leitor das crônicas, tão a par dos últimos acontecimentos, como o escritor. A sátira pode se passar num mundo totalmente absurdo e inverossímil.

Também a relação da sátira com a ironia é um elemento importante para a análise. Northrop Frye (1990), num dos quatro ensaios que compõe a sua Anatomy of 
Criticism, distingue a ironia da sátira e aponta dois aspectos essenciais do "gênero"184: "The chief distinction between irony and satire is that satire is militant irony ... Two things are essencial to satire; one is wit or humor founded on fantasy or a sense of the grotesque or absurd, the other is an object of attack." (Frye, 1990, p. 223/224). Uma ironia militante: talvez seja esta a melhor definição do tipo de obra que temos em mãos com a leitura comparativa de Os Bruzundangas e L'Île des Pingouins. Frye aponta ainda para um padrão moral implícito, já que entre o autor e o leitor é necessário haver, para o sucesso da empreitada satírica, um acordo do que é convencionalmente tido como engraçado, grotesco. O próprio ato de seleção inicial do satirista se configura para o autor, como um "ato moral".

Na linha que ultrapassa a configuração de gênero literário, a sátira é pensada por Paul Simpson (2003) como uma prática discursiva composta de um genus, um aspecto cultural, e um impetus, uma qualidade oriunda da desaprovação do satirista. Assim como Frye, os componentes essenciais da sátira são, de um lado, o acordo cultural no compartilhamento de padrões morais e sociais entre narrador e autor, e de outro, um ímpeto de agressividade necessário ao autor da obra e direcionado a um alvo preferencial. Simpson propõe ainda a figuração de uma tríade essencial na sátira composta pelo satirista (the satirist), que corresponde ao nosso narrador, o "satirée", no caso, o leitor, e o satirizado (the satirised), a vítima do satirista, seja ela uma pessoa, um episódio, ou mesmo outro discurso. Nessa tríade, enquanto os dois primeiros são participantes do ato satírico, o terceiro é o excluído na relação, ou melhor, o alvo dos ataques.

Em termos gerais, temos, no caso de Os Bruzundangas, a figura do próprio narrador como satirista, o leitor contemporâneo a Lima Barreto como o "satirée" e o satirizado dispersado em figuras, episódios e situações inspiradas no Brasil. No caso da história dos pinguins, essa figuração se repete estruturalmente, com o narrador como o satirista, o leitor contemporâneo a France como "satirée"e como satirizado temos o país dos pinguins como alegoria da França, e uma crítica explícita ao mundo clerical. Porém, há nesta classificação, um elemento deixado de lado que, para viabilidade do projeto crítico, é imprescindível. Trata-se do local peculiar do leitor não contemporâneo aos autores diante de obras tão ligadas ao contexto de produção. Reler uma sátira é um

\footnotetext{
${ }^{184} \mathrm{Na}$ concepção que adotamos anteriormente da sátira como modo de imaginação em Lukács, não há uma formulação de gênero. Seguiremos com essa perspectiva, por isso a referência ao termo gênero entre aspas.
} 
exercício constante de atualização dos elementos satirizados, pois sem essa adequação, a compreensão do texto fica fortemente comprometida. Mas como fazê-lo? Como atualizar uma escrita tão colada ao seu contexto de produção? Será somente a partir do desvendamento das chaves da obra, como no roman à clef $^{185}$, que se torna viável a compreensão real da ironia satírica?

\section{Sorriso melancólico}

Se, até o momento, estudamos a ironia verbal contida na frase ou na intenção do narrador, na ironia militante das sátiras, há uma mudança de ênfase. Esse olhar, particularmente sobre a ironia anatoliana, foi proposto por Theodor Reik (1953). Segundo Reik, são dois os tipos de ironia em France, a ironia verbal, que norteou esse estudo até o presente momento, e a atitude irônica, um elemento da visão de mundo do autor. Reik trata primeiramente do processo de leitura da ironia, no qual um impulso inicial de oposição é substituído pelo prazer diante da revelação daquilo que o escritor (speaker) intencionava dizer. Essa definição, Reik toma emprestada de Freud, mas o que lhe interessa particularmente é o processo existente entre a antiga e a nova atitude do leitor. Nele, existe, segundo Reik, a emergência de uma memória inconsciente que parece reavivar a tristeza e o desapontamento: "In the ironic expression not only are the old illusion and the old disenchantment reawakened from the past, but also the indignation and the bitterness" (Reik, 1953, p. 166).

Reik parte de uma definição de ironia do próprio Anatole France, que em estudo sobre Alfred de Vigny, afirma que a ironia é "la dernière phase de la désillusion", para observar onde estaria o primeiro desapontamento do autor. Com este fim, examina o conto de France, Le Jongleur de Notre Dame ${ }^{186}$, como se fosse um sonho e se utiliza do método psicanalítico para buscar esse universo perdido do autor. Foge ao escopo do presente trabalho uma análise autoral, caminho seguido pelo psicanalista, porém, Reik

${ }^{185}$ A inspiração do roman à clef em Lima Barreto pode estar na base do seu modelo satírico. Em texto já citado sobre o romance de Vinício da Veiga, Barreto afirma: "A fôrça dos romances dessa natureza reside em que relações do personagem como modêlo não devem ser encontradas no nome mas na descrição do tipo, feita pelo romancista de um só gole, numa frase.” (IL, 1956, p. 202). Se o processo de caricaturização está na base da escrita satírica, esse tipo descrito "de um só gole" parece figurar como o personagem satírico.

${ }^{186}$ Este conto foi incluído na coletânea L'Étui de Nacre, publicada em setembro de 1892, pela Calmann-Lévy, com uma edição corrigida pelo autor, de 1922. Consta no volume I da Pléiade. Trata-se da história do malabarista Barnabé, um homem simples e devoto que, por uma ironia do destino, torna-se religioso. No monastério, porém, não encontra uma forma de louvar a Virgem Maria, como seus pares o fazem. Enfim, resolve apresentar em segredo seus truques para a santa. Quando os outros religiosos tomam conhecimento, consideram a homenagem um sacrilégio, mas a própria santa desce do altar para defender Barnabé. 
faz uma observação em meio ao exame do conto, que nos chama a atenção. Ele observa que a ironia de Anatole France produz no leitor, depois do processo de reconhecimento, um sorriso, no qual é possível ler os traços de tristeza e melancolia. Interessa-nos trazer essa reflexão de Reik para propor uma mudança na perspectiva analítica. Se, até o momento, optamos pela busca de indícios da ironia verbal nos textos, no caso das sátiras, o objetivo será o de analisar muito mais a atitude irônica dos narradores, como uma posição dentro de seus respectivos contextos sociais, políticos e, eventualmente, emocionais. A atitude irônica do satirista se reflete no leitor num sorriso melancólico provocado pelo reconhecimento satírico, um humor contido diante de uma crítica contundente. Uma tristeza diante da constatação das limitações humanas.

Esse sorriso melancólico nos parece muito próximo à resignação melancólica que Prado (2008) observa como um dos movimentos presente no conjunto de contos reunidos em Histórias e sonhos, conjunto que representaria uma síntese da obra de Lima Barreto. Para o crítico, o vigor da resistência de Lima Barreto nos seus anos de anarcomaximalista “... parece contaminar-se de uma certa resignação melancólica”, uma resignação que almeja ao mesmo tempo "ligar a humanidade aos sentimentos que a redimam" e projetar-se "num solidarismo tocado pelo mistério, pela compreensão da dor infinita de seres humanos, com vistas a atingir a glória e a perfeição da humanidade." (Prado, 2008, p. XIV). Assim como nos contos, nas sátiras é possível vislumbrar também os dois outros movimentos apontados por Prado, o picaresco moralizante e o inconformismo submisso. Este último se revela principalmente, segundo o crítico, nos últimos anos de vida do autor, a partir sobretudo da experiência no hospício. Ele é decisivo, pois integra a matéria literária "às intervenções mais fundas de um Lima Barreto libertário e mais humano, rebelde e ao mesmo tempo melancólico" (p. XXV). Ao mesmo tempo em que ataca a elite das Bruzundangas, Lima Barreto não deixa de o fazer com uma dose de poesia e tristeza no olhar satírico:

"Pobre terra da Bruzundanga! Velha, na sua maior parte [...] toda a sua missão tem sido criar a vida e a fecundidade para os outros, pois nunca os que nela nasceram, os que nela viveram, os que a amaram e sugaram-lhe o leite tiveram o sossego sobre o seu solo!" (Bru, 1998, p. 09).

Ao humanismo melancólico e ao inconformismo submisso, agrega-se o picaresco moralizante, que está no cerne da compreensão paródica do Brasil em $O s$ Bruzundangas. Nesse movimento, encontramos "um tom de moralidade à maneira das histórias exemplares" (p. XVI). Esse caráter exemplar está na tentativa de salvação do 
país que Barreto aponta no prefácio em relação ao modelo da Bruzundanga: "Com este exemplo, os menores daqui poderão ser denunciados por este grandalhão de lá [...] e o nosso povo poderá livrar-se deles." (Bru, 1998, p. 08). Ou no intuito da sátira da Bruzundanga, que é fornecer matéria prima para "livrar-nos, a nós do Brasil, de piores males”. (p. 07). Portanto, ao sorriso melancólico do leitor - no misto entre o humanismo e o inconformismo - agrega-se o tom moralista das sátiras, que intencionam corrigir, ainda que de forma velada, a injusta estrutura social.

\section{Visada satírica}

Em Negócio de Maximalismo ${ }^{187}$, Barreto enaltece a "troça” como "a maior arma de que nós podemos dispor ..." e repele a violência: "Nada de violências, nem barbaridades. Troça e simplesmente troça, para que tudo caia pelo ridículo. O ridículo mata e mata sem sangue.” (CRJ, 1956, p. 119). Não estaríamos próximos do julgamento anatoliano através da ironia e da piedade? Dessas "deux bonnes conseillères", cujo riso acalma a cólera e nos ensina a "moquer des méchants et des sots, que nous pouvions, sans elle, avoir la faiblesse de haïr" ? (JE, 1923, p. 43).

Esse movimento trocista não é novo na obra de Barreto, pelo contrário, aparece já nos escritos de juventude, como na crônica Ópera ou circo $^{188}$. Temos neste texto o escárnio em relação à elegância européia dos frequentadores do Lírico, temática recorrente na obra do autor. Na crônica, o narrador elucida a dúvida do Sr. Antoine, um interlocutor imaginário, e, pelo nome, estrangeiro, acerca do "teatro da Guarda Velha", no qual convivem os sinais de um circo, "nas barras hercúleas de ferreo que atravessam a sala", e de uma ópera, no "ar petulante e faustoso da sala". O próprio narrador tivera a mesma dúvida anteriormente e um colega lhe dissera tratar-se do Lírico, o teatro da elite carioca. Naquela ocasião, depois de elucidada a questão, o narrador retornara para casa, satisfeito por saber que "aquele tapume engalanado a ópera, faustoso e soberbo era o Lírico".

Lá pelo meio da crônica, o narrador interrompe a explanação inicial para elucidar a questão ao suposto interlocutor que se materializa no leitor: "Creio que me expliquei mal. Naturalmente acham os períodos acima nebulosos por demais; mas

187 A crônica foi publicada no dia 20 de setembro de 1919, na Revista Careta, e se encontra reproduzida na edição da Brasiliense, volume VIII, Coisas do Reino do Jambon, e no volume II de Toda Crônica (TC2, 2004, p. 21).

${ }^{188}$ A crônica foi publicada em 23 de julho de 1903 na Revista Tagarela. Consultamos o texto no volume I de Toda Crônica (TC1, 2004, pp. 66-67). 
exemplificar-me-ei para melhor compreensão". A situação é posta então de outra maneira, na forma de uma adivinha: "Supondo: largo do Machado, num barracão de quintal, canta-se a Marcha de Cadis, se está o high-life de casaca - que é? É o Lírico". A voz do interlocutor/leitor se mistura então ao narrador e pergunta: "Mas porque é Lírico?". Hesitante, o narrador responde a charada enfatizando a vestimenta do público como elemento definidor do espaço artístico: "Porque... Porque... Porque se está de casaca...". A vestimenta individual usada pelos frequentadores do espaço responde à dúvida acerca do espaço de duplo significante, circo ou ópera. O espaço se cristaliza na figura de seus frequentadores. Dois procedimentos chamam a atenção nesta crônica: o nivelamento irônico da alta com a baixa cultura e a ênfase no signo externo como explanador da distinção entre estes dois níveis de representação.

Parece-nos que nesta explicação do Lírico, Barreto realiza algo a mais que a ironia que vimos até então trabalhando nas inversões e caricaturizações, adentrando o universo paródico. Segundo o filólogo russo, Vladímir Propp, a paródia "tende a demonstrar que por trás das formas exteriores de uma manifestação espiritual não há nada, que por trás delas existe o vazio" (Propp, 1994, p. 84-85). Propp sugere como ilustração para o conceito o exemplo da imitação dos movimentos graciosos de uma amazona de circo por um palhaço. Nesta situação, temos uma aparência de elegância, sendo que o que existe de fato é o seu contrário, a não graciosidade do palhaço. No caso da aproximação entre o circo e a ópera, trata-se de um outro tipo de associação entre o signo objetivo e subjetivo. Subjetivamente, pela vestimenta elegante, sabe-se que se trata da ópera, porém, diante do "barracão de circo", a situação objetiva opõe-se ao signo exterior de distinção. Nesta operação, o que existe de fato é um barracão de circo, porém, subjetivamente, trata-se de uma ópera. $O$ real aparece dissolvido na subjetividade do signo exterior de riqueza. Além da troça, Barreto elabora também aqui uma denúncia. Trata-se da utilização da paródia como instrumento de critica social, que subverte ironicamente os contextos de alta e baixa cultura, seguindo na mesma lógica da denúncia do falso que perpassa a obra limabarretiana.

É interessante notar ainda o jogo narrativo que o cronista empreende. Ele sugere ao duplo interlocutor (leitor e sr. Antoine) que imagine a seguinte situação: viajam num bonde uma senhora e um cavaleiro trajando vestuários finos e a "soberba capa da senhora faz pendant ao elegante sobretudo do senhor". O interlocutor se perguntaria então, supõe o narrador, por qual razão estaria num bonde um casal tão bem vestido, ao 
que ele responderia "É o Lírico". Neste jogo de perguntas e respostas, repete-se a dúvida entre aquilo que se vê: um casal bem vestido no bonde em direção ao circo; e aquilo que de fato a imagem significa para a sociedade carioca, o elegante casal a caminho da ópera. Essa discrepância entre o real e a imagem do real é o que garante a comicidade das cenas, seja ainda no exagero da sensibilidade do público, quando o narrador comenta que sentira certa vez "na fisionomia de um espectador a mágoa de ouvir desafinar uma nota", seja na associação entre o auditório e as figuras circenses, pois estando a sala cheia, lá se viam:

“... malabaristas de câmbio, acrobatas dos códigos (francês, inglês, etc.), [...], equilibristas da corda bamba da vida, e por fim, uma coleção de animais exóticos presentes na plateia: "papagaios parlamentares; macacos velhos que não metem mão em cumbuca; hidras da oposição; serpentes da intriga; patativas do norte (vulgo meninos prodígios); uniolho biográfico (animal da Polinésia onde o mar toca piston); etc". (TC2, 2004, p. 67)

Todo esse arsenal de ironia, paródia ${ }^{189}$ e satirização se repete em outros gêneros da obra limabarretiana, como no conto Como o 'homem' chegou, de 1914. Do ponto de vista da fábula, trata-se da prisão e do encaminhamento de um homem de Manaus para a capital carioca, empreitada realizada pelo delegado Cunsono a pedido do doutor Sili. A delegacia de Cunsono, como o próprio nome do agente policial já sugere, fica numa pequena cidade pacata e ordeira, sem grandes acontecimentos. De lá, o delegado sai à busca do dito homem na sua "masmorra ambulante", uma espécie de carro blindado designado por Cunsono para a missão. No trajeto, outros personagens são introduzidos na narrativa: o doutor Barrado, opositor do homem na cidade (cujo nome, Fernando, nos é revelado no percurso), quem auxilia na prisão do inimigo (que não apresenta resistências); e o antropologista Tucolas, "sábio naturalista, e antropologista, e etnografista da novíssima escola do Conde de Gobineau, novidade de uns sessenta anos atrás" (PS, 2006, p. 1166), quem guia a caravana ao mesmo tempo em que realiza suas pesquisas. É Tucolas quem calcula a distância a percorrer, que, de acordo com o mapa, não devia passar de "palmo e meio". Ao fim de quatro anos de trajeto, enfim, o "carrião entra pelo Rio adentro"; porém, o homem já havia há muito sucumbido.

Bem mais trágico do que permite a brevidade da crônica, nesse conto, os indícios satíricos retomam alguns recursos já estudados nos romances, na animalização

${ }^{189}$ É importante ressaltar que estamos trabalhando com a noção de paródia de Vladímir Propp que centra sua análise numa ampla gama de situações e tipos textuais. Nada tem a ver com a paródia literária que reproduz o estilo de um autor como forma de distinção ou crítica a uma escola literária particular. 
dos personagens e na comicidade oriunda dos inusitados campos semânticos escolhidos. O que chama a nossa atenção no conto e que o diferencia da crônica é o caráter trágico do desenlace da trama. Assim como o sorriso melancólico de France, o exagero dos vícios e defeitos, que tem como efeito a comicidade na narrativa, esconde o viés trágico reservado ao personagem central ali escondido, o dito homem. Neste sentido, quanto maior a relevância do personagem, maior nos parece ser o potencial trágico do exagero cômico.

Vejamos como ele aparece nas três situações. Na crônica, o narrador se dirige ao sr. Antoine que parece fazer o papel do leitor, uma figura geral, sem especificidade. No conto, temos alguns personagens caricaturizados e o homem, escondido, cujo destino é trágico. Já no romance, o personagem tem contornos mais claros e o lado trágico de seu itinerário está presente no desencanto de Isaías em seu caminho de incorporação ${ }^{190}$. Nesta gradação do cômico ao trágico, a centralidade do personagem parece ter importância significativa. Vejamos, então, o caso anatoliano, antes de retomarmos a dissolução desta figura nas sátiras, que acompanha, de certa maneira, o tom direto das crônicas, porém, mais dissimulado.

Vejamos, a presença do satírico nos romances anatolianos ${ }^{191}$. A caracterização de Jean Coq e Jean Mouton pelo sr. Bergeret, em conversa com seu discípulo Goubin, durante a Exposição Universal de 1900, segue caminho parecido à ironização limabarretiana de Cunsono e Sili (em inglês silly). Buscando criticar a onda de xenofobia dos nacionalistas, o narrador cria esses dois personagens cujas línguas são o "cocorico" e o "bêe, bêe, bêe". De forma semelhante ao conto de Barreto, há um procedimento de animalização das figuras que são alvo da pena satírica. Talvez, no caso anatoliano, seja possível pensar numa inspiração fabulesca, na mistura do humano com o animal e na fala destes em linguagem particular, uma forma bem anatoliana de "moquer des méchants et des sots", como aconselham a sua ironia e piedade.

Parecem-nos também relevantes alguns procedimentos que se assemelham nos dois autores, como é o caso da catalogação de nomes para definir um objeto. No caso do conto de Barreto, o veículo de transporte do homem foi nomeado de diversas formas: o “carro-forte", a "calistênica", a "prisão de Calístenes", a "almanjarra", o "estafermo", o "ergástulo ambulante". No caso de France, durante o passeio do sr. Bergeret com a sua

${ }^{190}$ Este elemento trágico está ainda mais presente no romance de Policarpo Quaresma.

${ }^{191}$ A diferença de gênero na obra de France é subestimada pelo próprio autor, o que nos autoriza a buscar elementos na obra sem necessariamente distinguir os gêneros, como fizemos com Lima Barreto. 
filha, o narrador elenca sinônimos para mendigo, "truands, cagoux, callots, sabouleux, franc-mitoux, courtauts" ${ }^{\prime 192}$. Trata-se, como aponta Bancquart, de um pastiche do livro Les Misérables, de Victor Hugo. Assim como o tom fabulesco da animalização, aqui também, a literatura entra como elemento estilístico. Segundo Claude Aveline, organizador dos textos mais políticos de France em Trente ans de vie sociale, a repetição de termos, trechos e referências na obra de France é um procedimento intencional e provocativo que, persuadido da leitura pouco atenta de seu público, acreditava “... qu'il pouvait faire repasser sous leurs yeux non seulement les mêmes lignes, mais les mêmes pages, sans courir jamais le risque de les voir repérées!" (VTM1, 1949, p. XXIV/XXV). Não sugeriria esta posição do narrador anatoliano um jogo travado com o leitor, de modo semelhante às charadas do cronista Barreto, ainda que um pouco mais elaborado?

Não é possível ver na obra de France uma diferenciação da importância do personagem relacionada ao gênero literário, porém, percebem-se alguns indícios de perda da relevância do herói intelectual no percurso da obra. Além disso, já vimos como o sorriso melancólico reflete bem a reação do leitor à obra mais crítica de Anatole France. Seria então a sátira, a despeito da perda de importância do herói, o método criativo ideal para revelar a decepção mais profunda desses humanistas? Seria somente uma radicalização no que diz respeito ao conteúdo ou surgiria deste método algum tipo de transformação formal?

O ódio diante da injustiça social está na base da concepção lukacsiana de sátira como método criativo, como já observamos em Nota sobre Recordações do escrivão Isaías Caminha. Para Lukács, a profundidade da sátira reside na exploração do conteúdo, diferentemente da qualidade formal da ironia. Esse modo de imaginação satírico tem para Lukács o pressuposto ideológico da indignação diante de um estado social "condenado à morte" (Lukács, 2009, p. 183). Assim como na crônica limabarretiana vimos uma radicalização crítica acompanhada da dissolução do personagem, o percurso satírico anatoliano, ao reforçar o aspecto denunciativo, também se traduz por um recuo do herói intelectual. O recuo do herói em France está diretamente ligado à perda do poder da palavra pelo intelectual, situação já sinalizada no

192 Bancquart explica em nota os significado dos termos: "Les truands sont des mendiants vagabonds, les cagoux ceux qui feignent de souffrir de maladies de peau, les callots sont de teigneux, les sabouleux de faux épileptiques; les francs-mitoux appartiennent á une tribu speciale parmi les truands; enfin, les courtauts de boutanche sont de faux ouvriers sans travail." (Bancquart, 1991, p. 1267). 
sábio suspeito em Crainquebille. É como se os seus heróis intelectuais fossem aos poucos deixando espaço para uma atitude literária mais combativa, focada na figura do narrador.

Enfim, a proposição satírica nas obras de France e Barreto seguem procedimentos que já encontramos em outros gêneros, como a animalização, a ironia, a comicidade de nomes, repetições e situações. Porém, na "ironia militante", apontamos dois novos elementos: a amargura contida na crítica e a dissolução do herói intelectual. Assim, não é mais somente o outro que é caricaturizado, mas tudo que está ao redor do satirista, do narrador. Nesta radicalização, portanto, são os traços trágicos (e também corretivos) que ganham força frente à individualização da conduta do herói exemplar.

Resta, antes de prosseguir em direção às sátiras, tratar de um elemento fundamental para o exame das mesmas: a presença ativa do leitor como desvendador das relações entre obra e realidade. Nos estudos detalhados já realizados por MarieClaire Bancquart da obra de Anatole France, muitas das relações se encontram cuidadosamente exploradas. Já no caso de Lima Barreto, além da biografia de Francisco de Assis Barbosa que fornece, por exemplo, a chave de elucidação dos personagens de Isaías Caminha, o foco de análise da obra do autor se centra ou na avaliação crítica da mesma, ou na apropriação do discurso do escritor no exame dos acontecimentos históricos ${ }^{193}$. Buscaremos a partir do exame de outros escritos limabarretianos e do estudo de Mauro Rosso acerca dos contos argelinos, traçar alguns elementos de ligação entre o real e o que está representado nesta sátira limabarretiana, seguindo, em parte, o trabalho já realizado da obra anatoliana. Antes, porém, trataremos brevemente das referências nominais a Anatole France em Os Bruzundangas.

\section{Método de julgamento}

Em Os Bruzundangas, o narrador faz duas referências a Anatole France. Numa delas, no quarto capítulo do livro, que trata da política e dos políticos da Bruzundanga, há uma alusão à coletânea de textos L'Église et la République ${ }^{194}$. O capítulo se inicia como a observação da riqueza sazonal do país que oscila entre a ostentação e a miséria;

193 Críticos como Antonio Candido, Alfredo Bosi, Antonio Arnoni Prado, Carmem Lúcia Negreiros, Osman Lins e Lúcia Miguel Pereira fazem parte da linha crítica, além de nomes mais antigos como o de Medeiros e Albuquerque, José Veríssimo, Fábio Luz, Nestor Victor, Tristão de Ataíde e Astrojildo Pereira. Na apropriação histórica, poderíamos citar nomes como o de José Murilo de Carvalho e Nicolau Sevcenko.

${ }^{194}$ Tratamos brevemente dessa coletânea no primeiro capítulo da segunda parte. 
fruto da vida econômica "artificial e falsa nas suas bases". A crítica dirigida propriamente ao político da Bruzundanga é que este, quando "se guinda às altas posições", separa-se da população, supondo-se de "carne e sangue diferente". O narrador cita então uma afirmação do historiador Jacques-Bénigne Bossuet $^{195}$, para quem o fim da política seria fazer os povos felizes; preceito ao qual os políticos da Bruzundanga se opõem, já que para eles o fim da política "é fazer os povos infelizes" (Bru, 1956, p. 66). A partir dessa breve introdução temática e referencial - como se repete em boa parte da obra -, o narrador exemplifica com algum caso que ilustre a sua "teoria". Nesse capítulo, trata-se de um senhor que, ao casar com uma moça rica, passa de positivista a católico praticante. A passagem abrupta do rapaz, "cuja insinceridade é evidente", e o auxílio das religiosas fazem-no galgar mais facilmente as posições almejadas. $\mathrm{O}$ casamento arranjado pelas irmãs de caridade, comenta o narrador, nada mais representa que um estágio para os "cínicos ambiciosos da Bruzundanga" alcançarem posições rendosas. É nesse momento que o satirista se refere a Anatole France:

"Tôda a gente sabe como o pessoal eclesiástico consegue manter a influência sôbre os seus discípulos, mesmo depois de terminarem os seus cursos. Anatole France, em L'Église et la République, mostrou isso muito bem." (Bru, 1956, p. 67).

E o satirista vai mais longe afirmando que a influência das irmãs de caridade não se restringe ao controle social por meio das moças católicas, acrescentando que um velho que conhecera escravos na Bruzundanga lhe contou terem sido essas mesmas religiosas "as mais tenazes inimigas da abolição da escravidão". A digressão dos casamentos arranjados e a influência dessas moças no meio político são utilizadas pelo narrador para explicar como o apoio do clero garantia aos políticos de lá uma posição na qual eles se viam isentos de atender às necessidades da população. A preocupação passava a ser somente a ocupação da máquina do Estado. Enquanto isso, a maior parte da população "vive sugada, esfomeada, maltraplilha, macilenta, amarela" (Bru, 1956, p.68). Ao fim do capítulo, o narrador retoma a afirmação de Bossuet, e finaliza dizendo que o historiador “... creio eu, não afirmou isso somente para edificação de algumas beatas ...”, unindo assim as duas referências ao polemista France e ao historiador

195 A citação está em Discours sur l'Histoire universelle (1681), no qual Bossuet, ao tratar dos governos egípcios, afirma que "la vraie fin de la politique est de rendre la vie commode et les peuples heureux" (Bossuet, Jacques-Bénigne. Discours sur l'Histoire Universelle. Paris: Garnier-Flamarion, 1966, p. 357). Obra acessada em 24/04/2013, na Digital Public Library, http://dp.la/ 
Bossuet. Ambos auxiliam o satirista a justificar e dar força aos seus argumentos, funcionando como o esteio de suas reflexões, legitimando a crítica do satirista.

A outra referência a France está nas últimas linhas do capítulo III, intitulado “A outra nobreza da Bruzundanga". Como fez com Bossuet no capítulo dos políticos, a palavra de France fecha o raciocínio do satirista acerca de uma das nobrezas daquele país. O narrador afirma ser esta "nobreza de palpite", "mais curiosa e interessante" do que a "nobreza doutoral", descrita anteriormente. A estrutura do capítulo é semelhante ao analisado acima, uma apresentação do assunto, uma exemplificação e uma finalização apoiada em alguma referência que autorize a reflexão. A nobreza de palpite é definida na negativa e em oposição à nobreza doutoral: ela não é "documentada por qualquer espécie de papel, édito, código, carta, diploma, lei ou o que seja" (Bru, 1956, p. 61).

O primeiro exemplo, para "elucidar bem o espírito dos leitores", é o de Ricardo Silva da Conceição, um cidadão da "democrática República da Bruzundanga" que muda de nome ao enriquecer, tornando-se Ricardo Silva de la Concepción. Ele o faz depois de ler um romance folhetim ${ }^{196}$, quando se convence de que é descendente da família do príncipe de Luna y Ortega e manda fazer cartões "com a coroa fechada de príncipe" (p.62). Assim, Ricardo Silva da Conceição vira o príncipe Ricardo Silva de la Concepción. O segundo exemplo é o de Ferreira que "fez uma viagem à Europa e voltou príncipe não sei de quê". Essa nobreza, apesar de menos reconhecida pelo povo que a nobreza doutoral, conhecia na Bruzundanga uma grande deferência da parte da gente rica e civilizada ${ }^{197}$.

É somente ao fim do capítulo, depois de contar mais dois breves casos, que o satirista introduz o aval anatoliano. Para o narrador, ambas as nobrezas do país deveriam ser julgadas "como aconselha Anatole France: com ironia e piedade" (Bru, 1956, p. 64). Se retomarmos o prefácio da sátira, particularmente na afirmação do autor

196 No texto, o narrador afirma se tratar do livro "Cavalheiros do Amor", de A. Carrillo. Procurando a referência, deparei com outro autor para o mesmo título, o filósofo português José Pereira de Sampaio Bruno (1857-1915), em edição portuguesa da Guimarães Editora, de 1960.

${ }^{197}$ É importante ressaltar dois elementos nestes exemplos: a critica pela falta de consistência do satirizado e a recorrência do descolamento do real, aqui na inspiração folhetinesca da nova titulação. Sobre a concessão de títulos nobiliárquicos no Brasil republicano, encontramos um decreto (n. 277, de 22 de março de 1890), no qual o então presidente Deodoro da Fonseca abole todos os titulos, foros de nobreza e ordens honorificas do antigo regime, com exceção das ordens de Aviz e do Cruzeiro. No site do Senado Federal, esse decreto se encontra revogado e já na constituição de 1891 , lê-se no artigo $72, \S 2^{\circ}$, parágrafo único, que a "A República não admite privilégios de nascimento, desconhece foros de nobreza e extingue as ordens honoríficas existentes e todas as suas prerrogativas e regalias, bem como os títulos nobiliárquicos e de conselho". 
que o país da Bruzundanga forneceria "matéria prima de sobra para livrar-nos, a nós do Brasil, de piores males" (p. 27), veremos que o emprego da ironia e piedade anatoliana como forma de julgamento é relevante do ponto de vista moral da sátira. Com esse "método", o satirista propõe quais deveriam ser os meios de julgar e sentenciar as nobrezas daquele país. O epítome anatoliano da ironia e piedade, assim como fora a sentença de Bossuet, funciona como um fundamento moral ao satirista, conferindo ao texto não somente a credibilidade da referência, mas também proporcionando o efeito corretivo da obra como proposto no prefácio.

Esse efeito corretivo é um dos fins das formas satíricas, segundo Charles Knight (2004). Knight trata de um tipo de "correção da percepção" nestas formas, efeito provocado pelo satirista, que, ao explicitar a relação entre o real e a sua representação, força seu interlocutor a um julgamento no qual eles se reconhecem como parte desse mundo reconstruído ${ }^{198}$. Desta forma, para que o efeito desejado pelo satirista seja alcançado, o interlocutor deve se reconhecer como parte desse mundo imaginário, ainda que não como alvo direto das críticas. No caso da alusão à ironia e piedade anatolianas, parece-nos que este método de julgamento pode ter contribuído para o reconhecimento do leitor brasileiro. Mas, essa referência a um escritor tão reconhecido nos meios literários brasileiros do começo do século XX também não se configura como uma provocação do satirista Barreto? Augusto Meyer, anos depois, trataria, como vimos, da mania do "anatolismo", um "feitiço, uma coqueluche, uma deliciosa peste", e todos "aludiam [...] ao evangelho da ironia e da piedade". Barreto se utiliza do evangelho anatoliano pervertendo-o, ou melhor, usando-o como arma de combante contra os mesmos que seguem a "deliciosa peste".

É neste sentido legitimador que Barreto se utiliza de suas referências. E nas sátiras, estas alusões se configuram também como um método de julgamento. A necessidade de um método de juízo é, segundo Knight, uma das distinções das sátiras em relação aos romances. O efeito corretivo da sátira pressupõe essa crítica. Knight chama a atenção ainda para três processos que ocorrem na passagem do romance à sátira: a centralidade da consciência individual se dissipa, reduz-se a afinidade moral entre autor e leitor e a preocupação com as questões sociais diminui a importância dos dilemas individuais. Diante dessa nova relação que se forma entre leitor e autor com a redução das questões individuais em benefício das sociais torna-se difícil, segundo

\footnotetext{
${ }^{198}$ Knight estuda a presença da forma satírica em diversos gêneros.
} 
Knigth, continuar a leitura da obra com as convenções do romance: "When personal consciousness and the sympathy of readers are replaced by social awareness and by a mixture of analysis and anger, it becames difficult to continue reading the work within the broad conventions of the novel" (Knigth, 2004, p. 205).

De um lado, temos, nas referências a Anatole France em Os Bruzundangas, a introdução de um método de julgamento que corrobora a busca satírica de produção de um efeito corretivo. Esse é o truque do satirista Lima Barreto ao se utilizar não somente das alusões a Anatole France, mas de outros como Bossuet. De outro lado, o leitor, na passagem do romance à sátira, começa a estabelecer uma outra relação com o autor, de adesão ou repulsa. Isso porque a identificação com a consciência e os dilemas individuais se dissipam, reduzindo assim a afinidade que se estabelece entre autor e leitor no romance. A perda da premência do herói modifica toda a relação de leitura da forma satírica.

\section{Contexto de publicação}

As obras de Anatole France estão, principalmente a partir de Les Opinions, abertas aos acontecimentos da época e estruturadas "par un commencement imprévu, puis une diversité des moyens mis en oeuvre, du pamphlet à la méditation, de l'anecdote au dialogue" (Bancquart, 1994, p. 1183). No caso da sátira dos pinguins, porém, há um elemento a mais. Trata-se, segundo a especialista, de uma obra publicada num contexto de crise do romance francês entre o fim do século XIX e o começo do XX. O momento na Europa também é de incertezas. Todo o continente parece assombrado pela iminência de um conflito bélico. No caso da França, desde a derrota para a Alemanha em 1870, o assunto segue presente nos debates públicos. Também não é possível desconsiderar os rumos do caso Dreyfus no país, com o esvaziamento das causas dos antigos dreyfusards, processo diretamente relacionado a uma perda do poder da palavra do intelectual. Todo este contexto de decepções e incertezas nos parece ter orientado o cético France numa busca por um outro meio de tratar desta realidade cada vez mais irrepresentável, que até então seguira os moldes do herói intelectual.

Além do já costumeiro método anatoliano da coletânea de textos publicados em jornal, Bancquart sugere que na sátira aparece um elemento novo denominado pela crítica de "dispersion en système". Na Ilha dos Pinguins, além da organização do material textual motivado pelos acontecimentos contemporâneos, o que se observa é um questionamento radical da história como disciplina científica. O rídiculo do historiador 
dos pinguins, Fulgence Tapir, o sábio a quem o narrador recorre sobre a arte pinguim, é o elemento chave dessa interrogação. A descrição física de Tapir - cujo nome em português se traduz por anta - se assemelha muito a de outros sábios do rol anatoliano, como é o caso de Coignard e Bonnard. Tapir tem, como os sábios, um nariz “allongé, mobile, doué d'un tact exquis". Mas diante dessa descrição, que no caso dos sábios seria somente ilustrativa, em Tapir, a ênfase recai sobre o nariz, um meio de ridicularização do personagem, pois é por meio deste órgão ${ }^{199}$ que Tapir "se mettait en contact avec l'art et la beauté" (IP, 1994, p. 09). Mais do que caricaturizar o personagem ressaltando os traços físicos, nesta descrição, o sentido do olfato se liga à condição animal, na mesma linha da animalização que observamos anteriormente em Mouton e Coq.

Em 1909, ano de publicação de L'Île des Pingouns, desta "oeuvre inclassable, dérision et virulence, caricature et réflexion”, nas palavras de Bancquart, já se tinham ido mais de dez anos do início do debate público iniciado com o caso Dreyfus e principalmente com a carta de Zola. A sensação é de fracasso entre os antigos dreyfusards. Figuras emblemáticas na defesa de Dreyfus, como Georges Clemenceau ${ }^{200}$, passaram para o lado da ordem, rumores de guerra ficavam cada vez mais fortes, e a esperança da transformação pela palavra se esvaia. Enfim, o pensamento não salvou o mundo, como muitos intelectuais acreditaram, dentre eles, o próprio France. A sociedade socialista que Bergeret projetava num futuro feliz, no romance Sur la Pierre Blanche encontra-se ameaçada pelos oponentes no interior mesmo do grupo socialista. Portanto, é grande a decepção de France a partir de 1906. Para Bancquart, "son amertume est totale" e o seu pessimismo, até então moderado por momentos de felicidade, tornava-se mais pesado.

Os textos que compõem a sátira L'Île des Pingouins apareceram inicialmente na imprensa em dezembro de 1905, no New York Herald. Nesta data, com o título Conte de Noël, foi publicada a história do santo Noël, que corresponde ao primeiro livro da sátira. Em abril de 1906, saia no mesmo veículo, uma série de textos sob o título de Le Dragon de l'île d'Alca, que corresponde ao segundo livro da ilha dos pinguins. Segundo Bancquart, porém, o verdadeiro começo da obra vem um pouco mais tarde, em julho de

${ }^{199}$ O nariz, inclusive, é alvo comum de peças satíricas, sendo recorrentemente enfatizado nas caricaturas. Na literatura, vale lembrar do conto comico-satírico de Nicolau Gogol, O Nariz, escrito na primeira metade do século XIX.

200 Como primeiro-ministro (1906-1909), Clemenceau reprimiu os movimentos grevistas, opondo-se fortemente a Jean Jaurès, socialista reformador e amigo de Anatole France. Ver Bancquart (1994a). 
1906, com a publicação no Le Journal de um artigo intitulado Qu'il est très difficile d'écrire l'histoire des Pingouins, texto que corresponde, com algumas modificações, ao conteúdo do prefácio da obra. No mesmo período, France aguardava a publicação de outra obra sua, Vie de Jeanne d'Arc, de 1908. O escritor previa uma recepção reservada ou hostil à obra - bastante irônica em relação à figura de d'Arc -, em função da adoração que a figura da mártir era alvo, tanto da direita como da esquerda, principalmente como símbolo da resistência francesa depois de 1870. Com esta obra, a permanência da posição crítica de France, a despeito da decepção com a realidade, não deixa margem para dúvidas. Nem uma figura mítica como Jeanne d'Arc fugia à pena anatoliana.

No caso de Os Bruzundangas, os textos ali reunidos foram publicados na imprensa em épocas distintas. Assim como no caso da Ilha dos Pinguins, as intenções iniciais eram bem diversas do texto final. Em dissertação de mestrado sobre $O s$ Bruzundangas e Aventuras do doutor Bogóloff, Elizabeth Lima (2001) comenta que foram muitos os intentos do autor:

“... escritas a princípio sob o título de Contos Exóticos; era ainda um relato de viagem imaginária; o romancista declarou que acalentava o desejo de produzir uma peça teatral e, por fim, a sátira temperou definitivamente todos os quadros da obra" (Lima, 2001, p. 46).

Essa "dança frenética de intenções", nas palavras de Lima, deu o tom à obra. Diante do texto final, Lima examina as várias possibilidades de gênero ali inscritas, de certa forma, retomando a confusa intenção inicial de concepção do livro. Do ponto de vista temporal, os textos que compõem a sátira foram publicados ao longo de 1917, sendo que o livro só sai em 1922, depois da morte do autor. A primeira referência, porém, sob o título Império das Bruzundangas, na Gazeta da Tarde, é de 1911, ainda que a maior parte tenha sido publicada mesmo a partir de janeiro de 1917, no semanário A.B.C., sob o título de República dos Estados Unidos da Bruzundanga. A edição em livro não escapou à sempre problemática publicação da obra limabarretiana. $\mathrm{O}$ editor Jacinto Ribeiro dos Santos publicou a obra em 1922 sob o título de Uma Província da Bruzundanga $^{201}$, contestado por Raimundo Magalhães ${ }^{202}$.

201 Em 1930, uma segunda edição vem a público. Os direitos da obra são adquiridos pela empresa $A$ Noite e o livro passa a pertencer ao patrimônio nacional. A família do escritor consegue do presidente Getúlio Vargas a liberação dos direitos autorais da obra. A edição de 1956, aqui utilizada, coteja a primeira edição de Jacinto Ribeiro e a terceira da Editora Mérito.

${ }^{202}$ Em A Tribuna, de 12 de dezembro de 1922, segundo informações de Francisco de Assis Barbosa. 
As crônicas que compõem o texto final de Os Bruzundangas fazem referência, na sua maioria, ao período de governo de Venceslau Braz (1914-1918). O período anterior, do governo de Hermes da Fonseca (1910-1914), está presente nos Contos Argelinos, como propõe a análise de Mauro Rosso (2010). Publicados entre 1914 a 1920, tratam principalmente do autoritarismo desse governo militar inserido entre regências civis ${ }^{203}$. No caso dos textos de Os Bruzundangas, concentraremos no ano de 1917 a busca de elementos de relação entre a obra e o período de governo de Venceslau Brás. Ainda que o aspecto autoritário, as intervenções do governo nos estados de Hermes da Fonseca tenham sido deixadas de lado, as crises econômicas se tornam cada vez mais presentes com Brás. Porém, essa delimitação não é restritiva, já que uma das figuras centrais nos contos argelinos reaparece nas Bruzundangas: o ministro João Pandiá Calógeras ${ }^{204}$, primeiramente chefe da pasta da Agricultura (1914-1915), do governo de Venceslau Brás, depois transferido para a pasta da Fazenda (1915-1916) durante o mesmo governo. Calógeras também exerceu a função de ministro da Guerra no governo posterior, de Epitácio Pessoa (1919-1922).

\section{Local e universal}

Para compreender a sátira de Lima Barreto, é fundamental retomar o contexto político brasileiro. No caso de Os Bruzundangas, a sua pré-história nos leva à sucessão que colocou Hermes da Fonseca no poder, processo particulamente complexo. Segundo Edgard Carone (1979), a primeira opção do então presidente Afonso Pena (1906-1909) era indicar para a sucessão o seu ministro das finanças, David Campista. Porém, o nome de Hermes, então ministro da Guerra, ganhou o apoio de Pinheiro Machado, do PRC (Partido Republicano Conservador), oligarca gaúcho com forte influência no congresso e nos meios militares. A oposição do PRP (Partido Republicano Paulista) lançou a

${ }^{203}$ O governo de Hermes da Fonseca (1910-1914) é o primeiro governo de um militar depois do primeiro período da Primeira República, com Floriano Peixoto e Deodoro da Fonseca. Ele sucede ao curto governo de Nilo Peçanha (1909-1901), vice de Afonso Pena (1906-1909), e é sucedido por Venceslau Brás (1914-1918).

${ }^{204}$ Calógeras (1870-1934) se formou em engenharia em Minas Gerais, por onde se elegeu deputado federal em 1987, pelo PRM, Partido Republicano Mineiro. Ele ganhou projeção com a publicação de As Minas do Brasil e sua legislação (geologia econômica do Brasil), de 1903, obra na qual distinguia as propriedades do solo e subsolo, defendendo o direito de desapropriação do último pelo governo. Sua tese foi transformada mais tarde na Lei Calógeras. Depois da participação no governo de Venceslau Brás, foi nomeado ministro da Guerra no governo de Epitácio Pessoa, de onde enfrentou os primeiros levantes tenentistas. Essas informações estão disponíveis no Dicionário Histórico Biográfico Brasileiro pós 1930. $2^{\mathrm{a}}$ ed. Rio de Janeiro: Ed. FGV, 2001, acessado em 17/11/2012, no site: http://cpdoc.fgv.br/producao/dossies/AEraVargas1/biografias/pandia_calogeras. 
candidatura de Rui Barbosa, criticando fortemente o militarismo dos hermistas. A morte de Afonso Pena e o conturbado governo do vice Nilo Peçanha só agravaram a situação. Hermes da Fonseca foi eleito depois de uma campanha bastante agressiva. Seu governo ficou marcado pela forte repressão às revoltas e agitações populares que aconteceram por todo o país. Segundo Carone, o governo de Hermes da Fonseca pode ser definido por um militarismo oligárquico desprovido do jabobinismo dos primeiros militares republicanos e positivistas.

Nos contos argelinos, o governo de Hermes da Fonseca é o alvo principal do satirista Lima Barreto, segundo Mauro Ross. A maior parte dos textos que compõem a coletânea foi publicada na revista Caretas. A inspiração "argelina" pode ter vindo de um procedimento muito usado por Lima Barreto de aproximação entre o universo político e as estórias ${ }^{205}$ exóticas ou exemplares. No caso dos contos argelinos, talvez a principal inspiração tenha sido o grupo de oficiais que ficou conhecido como os "jovens turcos"206, que por volta de 1914 e 1915, depois de estagiarem no Exército alemão, começam a campanha pelo serviço militar obrigatório, defendendo a intervenção dos militares na política. Ou, como também sugere Rosso, é possível se tratar de uma referência à "história de subjugo e militarização" da Argélia ${ }^{207}$.

O que nos interessa na matriz argelina é, de um lado, o exame dos procedimentos de escrita, e, de outro, o traçado de uma cronologia da crítica política limabarretiana. A "intensa utilização da alegoria, mesclada à sátira, ao sarcasmo, à ironia" e a "exploração do imaginário exótico e figurativo por meio de simulacros" (Rosso, 2010, p. 48), são os elementos textuais que Rosso identifica nos contos argelinos que, como ele mesmo observa, já haviam sido utilizados nas primeiras crônicas que compõem Os Bruzundangas. Do ponto de vista ideológico e político, a matriz oriental dos contos argelinos - bem mais presentes nestes do que no retrato do longínquo país - serviu para que Lima Barreto expressasse, segundo Rosso, o seu "bovarismo à brasileira", utilizando a ambientação orientalizada como motivo para uma ou pitoresco.

${ }^{205}$ Utilizaremos o termo estória como equivalente a anecdote, uma narrativa de um fato curioso

206 Essa nomeação era uma referência aos jovens reformadores militares de Mustafa Kemal, comandante militar do então Império Otomano durante a Primeira Guerra que, ao lado dos alemães derrotou, na Austrália, as forças aliadas. Na fundação da República da Turquia em 1923, Kemal foi eleito o primeiro presidente. Ver Rosso (2010, p. 47).

207 A política colonial francesa é também alvo da denúncia de Anatole France que protesta em textos como "Contre la Barbarie Coloniale" [VTM; (1)1949, (2)1953, (3)1963, (4)1973]. 
crítica ao patrimonialismo, que estaria presente tanto nos sultanatos e como no país das Bruzundangas.

Em $O$ anel de Perdicas, um dos contos argelinos, o narrador retrata um reino que dependia do imperio "em tudo que tocasse as relações com os países estrangeiros" (Barreto apud Rosso, 2010, p. 101). De um ponto de vista geral, a narrativa destes contos é breve, com frases curtas e diretas, marcada pelas descrições físicas de personagens como El-Sulida ${ }^{208}$, "príncipe velho, de pouca barba, curto de pernas, rico de muitas fazendas, que desejava do fundo da alma povoadas de escravos" (p. 102). A mistura entre descrição física e moral é uma constante nos contos. Como na maioria das crônicas limabarretianas, depois da breve introdução da questão e da descrição de ElSulida, a narrativa deixa o campo da política para tratar de uma pequena estória na qual o então príncipe, velho e doente, depois da indecisão da Assembleia em escolher o novo príncipe, designa o seu sucessor, o desconhecido Sancho, que o narrador esclarece ser o suposto futuro genro de Sulida.

Segundo Rosso, o texto retrata a crise política no Rio de Janeiro, antes da posse de Venceslau Brás, envolvendo a disputa pelo governo do estado do Rio de Janeiro em 1912, entre Feliciano Sodré e Nilo Peçanha, disputa essa que envolvia uma antiga querela, disputas pessoais, "além do interesse puro e simples pelo poder" (Rosso, 2010, p. 101 $)^{209}$. O que nos parece interessante apontar a partir da análise de Rosso é o tipo de associação recorrente tanto nas crônicas como na sátira limabarretiana entre o evento histórico e a estória exemplar. Bancquart apontou para este aspecto em Anatole France no duplo localismo e universalidade na narrativa dos pinguins. O localismo designado na relação com o contexto particular da situação narrada e a universalidade a partir do modelo anedótico das narrativas pitorescas.

Uma das figuras políticas mais satirizada por Barreto é o político Pandiá Calógeras. Ele aparece em Os Kalogheras, nos contos argelinos, em crônicas e também no país das Bruzundangas. Nos contos argelinos, o aspecto guerreiro da origem de

${ }^{208}$ Rosso afirma tratar-se de Feliciano Sodré, antigo aliado de Nilo Peçanha.

${ }^{209}$ Em 1908, Nilo Peçanha elegera o seu sucessor para o estado do Rio de Janeiro, Oliveira Botelho. Porém, este rompe com Peçanha e apoia Feliciano Sodré, candidato de Pinheiro Machado. Em 1912, Peçanha decide competir nas eleições contra Sodré. As eleições correm normalmente, mas as duas partes se declaram vencedoras e enquanto os deputados governamentais, que apoiam Peçanha, impedem a entrada da oposição, esta ganha um habeas-corpus concedido pelo Supremo Tribunal Federal para iniciar o mandato. A celeuma da duplicidade de Assembleias dura até 1915 com o assassinato de Pinheiro Machado e o reconhecimento de Peçanha. Os acontecimentos mais detalhados estão em Carone (1979, p. 312-313). 
Calógeras é o ponto central da troça limabarretian. No texto, o elemento local aparece na referência à mobilização das tropas nacionais para a expedição da Bahia, que teria causado espanto até mesmo a Basileus Epitaphio, clara referência ao Presidente Epitácio Pessoa. Calógeras foi o primeiro civil a exercer o cargo de ministro da Guerra e a questão sucessória na Bahia em 1919 levou o governo de Epitácio Pessoa a intervir no Estado. De fato, o conflito entre poder central e oligarquias locais foi um problema que todos os presidentes da Primeira República tiveram de enfrentar. Mas a posição pretensamente "neutra" de Pessoa, segundo Carone, agravava ainda mais a situação. Já o universal aparece na ascendência grega e ficcional do político, espécie do bovarismo constantemente criticado por Lima Barreto. Na sua caracterização, o narrador constrói um tipo cujas virtudes guerreiras teriam sido louvadas até mesmo por Homero que "na Ilíada, tem um verso em que se alude a altos feitos dessa família predestinada” (Barreto apud Rosso, 2010, p. 106).

Em crônica publicada em março de 1920, intitulada $O$ 'Negócio' da Bahia, Barreto trata da mesma temática e os termos usados nos contos argelinos já aparecem ali nas partes finais do texto:

"Cabe a cada baiano desprezar totalmente a política e fazer isso de tal
modo que nunca mais vejamos o arconte Calógeras, o polemarca do
Basileus Epitácio, debruçado sobre mapas, alta noite, no Quartel-
General, planejando um movimento envolvente e fulminante que
esmague de vez os seus patrícios baianos, com que obteria a glória
que o seu antepassado Alexandre da Macedônia levou para o túmulo e
até agora não quer deixar pousar mais na cabeça de qualquer dos seus
descendentes." (Bag, 1956, p. 271)

Todos os elementos satíricos já se encontram enunciados na crônica: a filiação grega, nos termos arconte, magistrado da antiga Grécia e polemarca - comandante supremo do exército entre os gregos -, a voracidade bélica de sua origem gloriosa e o desprezo pelos meios democráticos. Essa relação entre a sátira e a crônica é, de fato, fundamental no estudo do satirista Barreto. Em geral, a maior parte dos elementos tratados nas sátiras já se encontra enunciado nas crônicas esparsas do escritor.

Partindo do mesmo personagem, Calógeras ministro da Guerra no governo de Pessoa, vejamos a sua representação em Os Bruzundangas. Nessa sátira, a crítica se concentra no período de governo de Venceslau Brás, "Idle Bhrás" na pena satírica do narrador, no qual Calógeras assumiu a pasta da Agricultura e, depois, a da Fazenda. No capítulo Um Grande Financeiro, o satirista enuncia a temática a ser tratada logo nos dois primeiros parágrafos. Explica que a República dos Estados Unidos da 
Bruzundanga dispunha de um Senado e de uma Câmara de Deputados, ambos eleitos por sufrágio direto e temporário, e que, do ponto de vista econômico, o pais vivia de "expedientes", sem estabilidade financeira. Por isso, surgiam constantemente "financeiros de todos os seus cantos e, sobretudo, do seu parlamento" (Bru, 1956, p. 47).

Depois da breve introdução, o narrador começa a tratar do dito financeiro. Inicia a descrição como se introduzisse uma fábula: "Naquele ano, isto há dez anos atrás, surgia na sua Câmara um deputado ...”. Esse homem, que falava muito das questões financeiras e econômicas, além de "outras cousas cabalísticas da ciência de obter dinheiro para o Estado", chamava-se Felixhimino Bem Karpatoso. A erudição do doutor, assim como a sua aparência física são descritas numa mistura de ficção e realidade com forte teor jocoso. Ele "tinha um ar de Gil-Blas de Santillana", lia o “chinês Ma-Fi-Fu" (Bru, 1956, p. 48) e, em função do seu saber financeiro fora relator do orçamento da receita. O primeiro indício de que Karpatoso poderia representar Calógeras é a alusão às jazidas de ouro e ferro, já que o ministro publicara em 1903 o livro As minas do Brasil e sua legislação. Mas o foco do satirista se mantém no tipo elegante, reforçando a descrição física do satirizado, que era tido como "o parlamentar mais chic do Congresso Nacional" (p.49). Segundo o satirista, o elogio ao requinte de Karpatoso nos jornais e colunas elegantes tinha origem nos rumores da sua iminente convocação para ministro da Fazenda.

No texto, outro personagem disputa a centralidade de Karpatoso como satirizado. Trata-se de Mikel de Longueville ou Mikel de la Tour d'Auvergne ou Mikel de Bouillon ou ainda Turence Calmon. Todos são uma só pessoa, o modelo de elegância que disputa com Karpatoso. A elegância de la Tour d'Auvergne era mais pesada com "algo de solidez lusitana", enquanto Ben Karpatoso a tinha "mais leve, mais ligeira, mais nervosa". Calmon fica aborrecido com o sucesso de Karpatoso, mas certo de sair como vice-presidente da Bruzundanga, "abafou o azedume". O cotejamento com uma crônica de Barreto, O ideal do Bel-Ami, elucida o tal personagem. Trata-se de Miguel Calmon du Pin e Almeida, engenheiro, colega de Barreto na escola Politécnica. Ele é a elegância personalizada. Como na crônica da ópera, a ênfase na vestimenta denuncia um descolamento do real. Porém, no caso da sátira, a crítica nos parece direcionada a toda a sociedade da elegante Belle Époque carioca, nos comentários e adesões às figuras eminentes dos dois estetas. Neste ponto, reside a sua ampliação, a sua universalidade. 
De outro lado, o narrador insere um personagem que é parte do círculo de desafetos pessoais do autor, um ressentimento pessoal. Mais que localista, a alusão envolve aqui a história pessoal escritor.

A ênfase do narrador, porém, não é no ressentimento, mas no descolamento do real que está na base de toda a concepção satírica limabarretiana. O tratamento do absurdo como trivial, o livre jogo entre o ficcional e o real, são procedimentos que reafirmam a todo momento este descolamento, seja nas "qualidades harpagonescas de economia e poupança" de Felixhimino, ou nos discursos do finalmente ministro da Fazenda, que ao responder a acusação de um deputado que afirma querer ele matar o povo de fome, diz que “... mesmo que viessem a morrer muitos, seria até um benefício, visto que o preço da oferta é regulado pela procura ..." (Bru, 1956, p. 52). Outras pérolas de Felixhimino como o vestuário majestoso para impressionar os estrangeiros, ou a conclusão de que o barateamento das passagens resultaria na desmoralização da família, aparecem no mesmo trecho da sátira. A crítica na sátira, portanto, não atinge somente o satirizado, mas todos aqueles que compõem o quadro de elogios falaciosos e alimentam os mitos destas figuras caricaturizadas pelo narrador. A ironia do satirista atinge a todos que reproduzem e estimulam o simulacro do poder.

Linda Hutcheon (1981), ao examinar a presença da ironia na sátira e na paródia, enfatiza a intenção do "auteur-encodeur" e o reconhecimento do "lecteur-récepteur", nas competências necessárias para o reconhecimento do código do autor: a competência linguística, na decifração do que está implícito; a competência genérica, do conhecimento das normas literárias e retóricas; e a competência ideológica, que envolve não somente o contexto de produção como uma "certaine homologie de valeurs institutionnalisées" entre autor e leitor. Hutcheon ainda discrimina um éthos equivalente ao espaço da ironia, da sátira e da paródia: "l'éthos moqueur" do primeiro, o "méprisant", do último, e um "éthos plutôt neutre ou ludique" da paródia. Esse estado inicial de delimitação do espaço da ironia, sátira e paródia é, então, colocado em movimento com múltiplas relações possíveis "du rire dédaigneux au petit sourire caché" (Hutchenos, 1981, p. 148). Neste sentido, cada uma dos três éthos, ironia, paródia e sátira, pode ser pensado em relação às competências requisitadas do leitor. A competência linguística visaria a compreensão dos mecanismos de ironia, a genérica, dos recursos parodísticos e estilísticos e a competência ideológica dos meios satíricos. 
No caso dos dois autores aqui estudados, o ponto principal, no que tange à escrita satírica é, de um lado, um olhar para os mecanismos textuais da ironia e, de outro, uma compreensão do universo político e ideológico das Repúblicas no Brasil e na França. Ou seja, exigem do leitor principalmente as competências línguística e ideológica, deixando de lado, na maior parte do tempo, a análise estilística. Os vícios das estruturas de poder e os absurdos do real são os aspectos ideológicos que os dois autores mais denunciaram nos seus respectivos países. E a denúncia não aparece somente nas sátiras, mas também nos textos de intervenção, seja no grande número de crônicas limabarretianas esparsas ou reunidas nas coletâneas da edição de 1956, seja nos textos reunidos de France na coletânea Trente ans de vie sociale.

Trata-se, portanto, para o leitor de sátiras, da composição de uma organização ética do mundo. Na visão de Osmar Pimentel, Lima Barreto foi "um filho espiritual do humanismo e do moralismo" 210 . Em sua obra, dois temas centrais são predominantes para o crítico, a piedade pelos injustiçados, "todos quanto não puderam realizar [...] seu natural destino humano", e a eficácia da inteligência e do idealismo "para uma possível organização ética da cidade dos homens". Logo na epígrafe de Os Bruzundangas, o satirista cita um fragmento de um texto de André Suarès ${ }^{211}$, Portraits, a primeira frase de Chroniques de Caërdal, "Hais tous maux où qu'ils ${ }^{212}$ soient, très doux Fils". O conselho de rejeitar todo o mal onde quer que ele estivesse antecipa o modelo exemplar e satírico apresentado no prefácio, um trecho do livro A Arte de Furtar ${ }^{213}$, particularmente o título do quarto capítulo: “Como os maiores ladrões são os que têm por ofício livrar-nos de outros ladrões" (Bru, 1956, p. 27). Temos, portanto, o conselho e o modelo às avessas. Em comum entre as duas referência estão os elementos moralizantes. Estamos tratando de uma correção do poder político e a busca errática de referências por Barreto parece confirmar a suspeita, pois elas se pautam pelo que se apresenta como modelar ou exemplar.

Num caminho inverso ao seguido acima, passaremos agora da crônica para a sátira. Interrompendo "a série de impressões que vinha escrevendo sôbre o país da

\footnotetext{
${ }^{210}$ Essas observações de Pimentel estão no prefácio da edição de 1956 de Os Bruzundangas, pp. 9-16. O texto fora publicado anteriormente na Fôlha da Manhã, de São Paulo, em 12/11/1949.

${ }^{211}$ Trata-se do pseudônimo de Isaac Félix Suarès, escritor e jornalista. Mais informações sobre a sua obra podem ser encontradas na base de dados da Biblioteca Nacional Francesa (http://data.bnf.fr).

${ }^{212}$ Na edição de 1956, está escrito erroneamente " $q u$ 'il soient".

${ }^{213}$ Livro do século XVII, endereçada ao rei português D. JoãoIV, escrito pelo padre Manuel da Costa, antes atribuído a Padre Vieira. A controvérsia que Barreto alude é em relação à autoria do livro.
} 
Bruzundanga" (VU, 1956, p. 118), Lima Barreto escreve a Carta Fechada - Meu Maravilhoso Senhor Zé Rufino ${ }^{214}$, na qual ele critica o sucessor de Pandiá Calógeras no ministério da Agricultura, José Rufino Bezerra Cavalcanti (1865-1959). A meio-termo entre a crônica e a sátira, a carta é irônica já na destinação do título ao "meu maravilhoso senhor Zé Rufino", e também nos procedimentos já vistos em outros momentos da obra limabarretiana, como a atribuição de diversos nomes ao satirizado Chico Caiana, Chico da Novilha, Zé Bezerra. O tom é agressivo, sem sutilezas. Logo no primeiro parágrafo, o cronista acusa: "Vossa Excelência é o mais cínico dos sujeitos que se fizeram ministro de Estado". Falta, porém, para se tornar satírico, o disfarce, o encobrimento do real com o efeito de causar maior impacto frente ao absurdo da realidade.

Na sátira dos Bruzundangas, a figura de Rufino aparece com o nome de Chico Caiana no capítulo intitulado Um Ministro. Nele, Caiana é o tipo do grande agricultor que nada entendia de agricultura, e o que está por trás do relato satírico de Barreto é a conturbada situação que resultou na nomeação de Rufino para o ministério da Agricultura em 1915. No capítulo, Caiana é apoiado pelo general Tupinambá - na verdade, o governador de Pernambuco, Dantas Barreto. O que se passa na época, segundo Carone (1974) é que José Bezerra perde a vaga no Senado para o candidato de Pinheiro Machado e o presidente Venceslau Brás, em apoio ao general Dantas Barreto e em oposição a Machado, reorganiza os ministérios, oferecendo a pasta da Agricultura a Bezerra. Lima Barreto descreve assim o processo: "O senado não o quis reconhecer; porém, mandachuva, que tinha a palavra empenhada com Tupinambá, arranjou as cousas.” (Bru, 1956, p. 101).

Para o reconhecimento do "lecteur-récepteur" de hoje é necessário desvendar os pormenores da história, para melhor compreender o texto de Lima Barreto. Porém, não há também uma universalidade na denúncia de Barreto? No início deste mesmo capítulo, o narrador fala sobre a recepção da obra. Comparando suas "notas" sobre a Bruzundanga com as "Histórias de Heródoto", o satirista afirma que se a posteridade desprezar os ensinamentos contidos na sua obra, "os contemporâneos do meu país podem achar nestas rápidas narrações de coisas de nação tão remota, moldes, receitas e meios para esbodegar de vez o Brasil” (p. 97). Ou seja, mesmo desconhecendo as

${ }^{214}$ A crônica foi publicada no semanário A.B.C. do dia 12 de maio de 1917 e depois reunida na coletânea Vida Urbana, volume XI da coleção da Brasiliense de 1956, pp. 118-120. 
equivalências históricas, a função destas notas ultrapassa o valor local. A função crítica é, neste sentido, ampliada em relação à estória particular ali contada, que não pode prescindir do leitor contemporâneo ou do desvendar histórico.

Do lado anatoliano, dois elementos fundamentais permeiam a sua escrita satírica e se assemelham ao modelo limabarretiano: a denúncia do absurdo do real nas inversões irônicas e a temática social paralela. No prefácio da Ilha dos Pinguins, escrito em primeira pessoa por um narrador não nomeado ${ }^{215}$, tomamos conhecimento do risível historiador cuja vida “est tendue tout entière vers l'accomplissement d'un grand dessein" (IP, 1994, p. 03): escrever a história dos pinguins. Num primeiro momento, a discussão parece ter um tom sério, argumentativo, mas, logo, o conselho do historiador consultado revela o risível da situação. Ele aconselha o autor da história dos pinguins a não deixar passar nenhuma oportunidade para exaltar as virtudes sobre as quais as sociedades se fundam: "le dévouement à la richesse, les sentiments pieux, et spécialement la résignation du pauvre, qui est le fondement de l'ordre" (p. 05). Não restam dúvidas quanto ao tom irônico deste aconselhamento, por tudo que já vimos da obra anatoliana. Assim como o prefaciador de Os Bruzundangas elege o exemplo em negativo daquele país com a intenção irônica de salvar os menores do Brasil, as virtudes exaltadas pelo historiador consultado são na verdade defeitos que devem ser revelados pelo satirista, cumprindo assim o seu papel corretivo. A exaltação das virtudes às avessas realiza a função mesma da sátira: corrigir um mundo injusto.

A temática da justiça social acompanha a obra literária de Anatole France. Do ponto de vista cronológico, há mesmo uma linha que começa na Histoire Contemporaine e que não finda com o término dos quatro livros da série. Sob o mesmo título, aparecem outras narrativas de France, entre elas, Crainquebille, já abordado anteriormente. As questões do caso Dreyfus não são mais o foco desse conto, mas sim a questão mais ampla da justiça social. Os textos de intervenção reunidos por Claude Aveline (1949) também acompanham o lado do escritor engajado em inúmeras questões de sua época, como em manifestação contre o despotismo russo ${ }^{216}$, no discurso

${ }^{215}$ Ao final do prefácio, só consta o local e data: “Quiberon, $1^{\mathrm{er}}$ septembre 1907.

216 Trata-se de um conflito entre estudantes russos e o governo de Nicolas II. As medidas draconianas do regime czarista provocam o protesto de escritores e professores russos que apelam aos seus pares ao redor do mundo. France foi um dos que assinou a mensagem de apoio dos escritores franceses. Ver Contre le Despotisme Russe (VTM1, 1949, p. 65-67). 
proferido na inauguração de uma gráfica comunista ${ }^{217}$, e em diversas inaugurações e celebrações das Universidades populares, conhecidas como U.Ps.

Neste período de desencanto, a atividade política de Anatole France permanece ativa. Porém, nos livros, as figuras dos intelectuais se encontram cada vez menos representadas. No prefácio, as palavras de Jacquot le Philosophe ${ }^{218}$, que "a dépeint leur caractère dans un petit tableau de moeurs" (IP, 1994, p. 07), aparecem numa pequena estória transcrita do suposto livro do filósofo. Trata-se de um diálogo entre o sábio Gratien, um filósofo "marsouin”, povo vizinho aos pinguins ${ }^{219}$, e um pastor de ovelhas. Nele, Gratien ouve o hino de guerra dos pinguins e pergunta ao pastor do que se trata. Este revela ser o canto um hino da guerra contra os marsouins que eles odeiam pelo simples fato de serem eles vizinhos dos pinguins: "Qui dit voisin dit ennemis" (p. 08). Ao final, aparece o tema do patriotismo associado a esse ódio ao povo marsouin e o pastor vocifera: "Vivent les Pingouins! Mort aux Marsouins!".

Essa pequena narrativa antecipa a transposição dos acontecimentos do caso Dreyfus no livro, alegorizado no "affaire des quatre-vingt mille bottes de foin". Os gritos são semelhantes às injúrias sofridas pelos defensores da inocência do capitão Dreyfus, principalmente direcionadas a Émile Zola. Michel Winock conta que no mês de janeiro de 1898, depois da publicação de J'accuse, a França foi tomada por uma onda de fanatismo, com manifestações em diversas cidades contra Zola e os judeus: "à Nantes, un défilé entraîne le bris de devantures de magasins juifs; à Nancy, la synagogue est prise d'assaut; [...] à Bordeaux, on profère comme ailleurs: 'Mort aux Juifs! Mort À Zola! Mort à Dreyfus!"” (Winock, 2009, p.170).

Ainda que o aspecto corretivo não seja tão explícito aqui como no prefácio de Os Bruzundangas, se considerarmos correta a associação entre Jacquot e France, o "récit moral" composto pelo filósofo propunha-se, como em Os Bruzundangas, a representar " $d$ 'une façon comique et forte les actions diverses des hommes" (IP, 1994, p. 09). E o próprio filósofo confirma a sua intenção corretiva ao ser indagado das razões pelas quais ele escrevera sua obra. Jacquot responde: "Lorsqu'ils verront leurs actions

${ }^{217}$ Inaugurada em 1901, tratava-se de uma "coopérative de production, imprimerie ouvrière et communiste". No discurso, France elogia a bela e difícil empreitada e termina com a seguinte frase: "vous vous êtes condamnés à la vertu à la perpétuité" (VTM1, 1949, p. 69)

${ }^{218}$ Bancquart sugere que esse filósofo poderia representar o próprio Anatole France.

${ }^{219}$ Segundo Bancquart, os marsouins podem ser tanto os alemães como os ingleses. Acreditamos tratar-se dos alemães em função do diálogo subsequente. A sátira dos pinguins também se define pela duplicidade local/universal na sua interpretação. Algumas vezes, o narrador se dirige a um alvo preciso e contemporâneo, outras aos franceses em geral ou mesmo à humanidade. 
ainsi travesties et dépouillées de tout ce qui les flattait, les Pingouins en jugeront mieux et [...] deviendront-ils plus sages". Parece-nos existir aqui uma breve fagulha de esperança para o intelectual.

O recurso às estórias exemplares (les anecdotes) também é uma maneira de equilibrar o tom mais agressivo com o mais jocoso da narrativa, incorporando na estrutura da obra a dualidade da ironia e piedade. Como já vimos, o livro dos pinguins começa a ser escrito no momento posterior ao caso Dreyfus, quando a união dos antigos dreyfusards já está enfraquecida. Aqueles que acreditaram que as palavras iriam mudar o mundo, experimentam agora um sentimento de fracasso coletivo. É esse movimento do otimismo à decepção que veremos particularmente na análise da transformação jocosa do caso Dreyfus. Bancquart aponta que os disfarces sistemáticos do real teriam por finalidade na obra anatoliana expor o que existe de errado na evolução da sociedade francesa e requisitar, assim, a reflexão dos homens. É este intuito corretivo que encaminha o autor para a sátira, um processo de radicalização crítica. Bancquart afirma que com a Ilha dos pinguins, "L'écriture est devenue violente, l'humour cruel, et c'est comme l'entrée dans notre siècle d'un homme formé au siècle précédent" (Bancquart, 1994, p. 82). Esse homem inadaptado vê na sátira a possibilidade de corrigir pela palavra o que ele observa de injusto no mundo. É talvez a forma mais radical de literatura militante.

Esta via militante da palavra tem consequências também na estrutura temporal da narrativa. Enquanto no fantasiado Brasil de Os Bruzundangas as coisas permanecem sempre as mesmas, como num eterno presente, na mascarada França, a história se repete incessantemente, a "histoire sans fin". Em ambos, o tempo não segue o fluxo progressivo: ou permanece inerte ou se dobra sobre si mesmo. Esse elemento temporal, porém, já foi observado nos romances. Mas, no encalço da escrita militante, a sátira nos parece ser no caso dos dois autores a radicalização máxima de suas escritas literárias. 


\section{Humanismo Satírico}

A longa história da ilha de Alca, onde vivem os homens-pinguins, começa com o batismo dos animais pelo santo Maël, seguida da metamorfose deles em homens. O livro como um todo é dividido em quatro partes: as origens, com a história de Maël e a metamorfose dos pinguins; os tempos antigos, na qual são descritas as bases dessa nova sociedade; os tempos modernos, nos quais são transpostos alguns dos acontecimentos políticos contemporâneos de Anatole France; e, por fim, a breve história sem fim do tempo futuro. Nos tempos antigos, as bases da nova sociedade já denunciam a posição crítica do narrador, seja a partir das vestimentas ali introduzidas - que despertam o orgulho de Orberose, pinguim fêmea que depois de morta se torna patrona daquele país - seja pela propriedade fundada na força física de Greatauk, que é nomeado “ $d u c s d u$ Skull" pelo religioso Bullock.

A posição crítica também aparece durante a primeira assembleia da ilha, na qual Morio, um dos mais ricos homens entre os pinguins, inverte o sentido da justiça social ao afirmar que o interesse público não deveria exigir muito dos ricos, porque como os mais pobres vivem do bem dos ricos, “ce bien est sacré” (IP, 1994, p. 50). Aplaudido, as ideias de Morio são seguidas pela violência das palavras de Greatauk que diz: "Étant noble, je ne contribuierai pas; car contribuer est ignoble. C'est à la canaille à payer" (p. 51). O narrador comenta tudo isso, expressando toda a sua indignação diante das palavras de Morio e Greatauk e da aquiescência dos presentes à assembleia:

"Bien que les enfants y mourrussent en merveilleuse abondance et que
les famines et les pestes vinssent avec une parfaite régularité
dépeupler des villages entiers, de nouveaux Pingouins, toujours plus
nombreux, contribuaient par leur misère privée à la prospérité
publique." (IP, 1994, p. 51).

Neste trecho, a ironia do narrador é incisiva ao criticar as bases econômicas injustas dessa sociedade. O absurdo das declarações de Morio e Greatauk nos remete ao diálogo entre grande financeiro Felixhimino e os deputados no país das Bruzundangas, no qual o primeiro é acusado de, com suas "ideias salvadoras", levar o povo à fome e obrigá-lo a andar nu. Sobre as vestimentas - aspecto também levantado pelo narrador anatoliano como marca de distinção social -, Felixhimino garante que os tecidos nobres, como a seda e o veludo não teriam seus preços aumentados, assim como outros itens de luxo, pois para ele o "vestuário deve ser uma cousa majestosa e imponente, para bem 
impressionar os estrangeiros que nos visitem" (Bru, 1956, p.52). Por essas observações similares, é possível notar em ambos o primeiro traço do que chamamos de humanismo sátirico: a posição anticapitalista de seus narradores e a crítica ao poder econômico como fonte das desigualdades sociais. O antiamericanismo de Lima Barreto é parte desse anticapitalismo, bem explicitado na crônica $O$ nosso 'ianquismo ${ }^{220}$, em que afirma que "o fundo do espírito americano é a brutalidade, o monstruoso, o arquigigantesco" (TC1, 2004, p. 480).

Retomando fábula e trama da ilha de Alca, os tempos antigos terminam com a história de um dragão que amedrontava os moradores de lá. Na verdade, trata-se do disfarce de um dos habitantes da ilha, Kraken, que depois de se casar com Orberose, monta um plano com o intuito de intimidar os homens-pinguins. A astúcia da bela Orberose, porém, transforma o aterrador Kraken em salvador do povo. O próprio dragão torna-se aquele que salva os pinguins do monstro. Ao fim, ambos são considerados os redentores do povo de Alca, e sua descendência funda a primeira dinastia real da ilha.

$\mathrm{Na}$ terceira parte, da Idade Média e Renascença pinguim, uma característica marcante é o grande número de referências utilizadas pelo narrador, algumas reais e outras, ficcionais. Além disso, é o trecho em que a erudição clássica anatoliana se faz mais presente. $\mathrm{O}$ que nos interessa do ponto de vista analítico é exatamente a mescla particular entre o real e o ficcional, assim como a configuração da ironia na obra. A partir desta terceira parte também, talvez pela maior proximidade temporal e pela incorporação de elementos mais nítidos da história da França, a crítica se torna mais explícita. Seja ela direcionada ao mundo religioso, como, por exemplo, quando o narrador explica as razões da unidade de crenças na ilha: "on brûlait immédiatement tous Pingouins qui pensait autrement que les autres" (IP, 1994, p. 82), seja ao mundo das artes.

Em relação às artes, um dos capítulos do terceiro livro trata especificamente da pintura primitiva dos homens-pinguins. $O$ trecho nos parece particularmente interessante no que diz respeito não somente aos traços da ironia, como também por alguns procedimentos que se assemelham aos usados no país das Bruzundangas. Nele, o narrador discute o nascimento da arte dos pinguins, numa clara equivalência entre a pretensa originalidade dos críticos da arte pinguim e da arte francesa. Trata-se do primeiro indício mais nítido de que estamos diante de uma alegoria da história francesa.

${ }^{220}$ Publicado na Revista Contemporânea, em 22-03-1919. 
O elogio, irônico, é embasado numa fonte ficcional e se justifica por uma tautologia. Diz o narrador que a arte primitiva dos pinguins pode ser comparada às italiana, alemã e holandesa, assim como à francesa. Sobre esssa última, afirma ser ela superior a todas as outras "comme le dit M. Gruyer", pois as artes francesas "ont plus de logique, la logique étant une qualité spécialement française" (IP: 1994, p. 86). De um lado, temos um autor ficcional, M. Gruyer, que sustenta a superioridade francesa, de outro, temos uma afirmação circular que nada diz do porquê de tal originalidade.

Assim como os nomes de autoridade ficcionais usados para tratar da arte francesa, também no mundo literário das Bruzundangas o narrador refere-se a alguns versos samoiedas encontrados na obra ficcional "Literature of the Stingy Peoples", do autor imaginário "Senhor H. T. Switbilter". O mesmo procedimento do narrador limabarretiano no uso das mais diversas fontes, inclusive do próprio Anatole France, para justificar os argumentos apresentados nas crônicas, também encontramos na sátira dos pinguins. De fato, o misto de ficção e realidade destas referências nos parece bem característico dos textos satíricos que, a todo momento, jogam com as habilidades do leitor no desvendamento da autenticidade das informações. Desse aspecto, o que fica de elemento particular ao nosso objeto é o paradoxo entre valorização e questionamento da informação, do conhecimento e da ciência. De um lado, as fontes sustentam a informação revelada; de outro, a mescla de referências reais e imaginárias desconstrói essa valoração. Os dois narradores requisitam, do leitor, um conhecimento amplo ao mesmo tempo em que jogam com a veracidade e com a autoridade dessas fontes. Enquanto a crítica ao capitalismo está na base ideológica destas sátiras, é possível afirmar que o questionamento da ciência e da crítica está na base do jogo que se instaura nestas duas narrativas.

É exatamente o que acontece na descrição das artes primitivas dos pinguins. $\mathrm{O}$ texto é repleto de referências as mais diversas, elucidadas na maioria das vezes pelas notas de Bancquart. Sabemos, por exemplo, por ela, que a voga dos primitivos estava em alta na França, o que incomodava Anatole France. Daí a ironia do narrador em relação à obra do pintor italiano do século XIII Margaritone d'Arezzo. Ele cita uma crítica negativa da obra, escrita pelo abade Lauzi ${ }^{221}$ para, no parágrafo seguinte, elogiar o "éminent théoricien du préraphaélisme, sir James Tuckett", e depois citar o

221 Trata-se de uma referência real segundo Bancquart, que está no livro Histoire de la peinture en Italie, de 1782, traduzida para o francês em 1824. Porém, o nome do abade autor do livro não é Lauzi e sim Lanzi. 
"séraphique esthète d'Édimbourg, Mac Silly" que tratou da obra "Madonna and Child Enthroned"222 de Margaritone, associando a experiência do espectador à pureza infantil. As duas últimas fontes são claramente ficcionais. A ironia do narrador é explícita ao transcrever as sensações de Silly ao apreciar a obra:

“... à l'âge de soixante-dix ans [...] je me sentis subitement transformé en un tendre nourrison. Tandis qu'un cab m'emportait à travers Trafalgar Square ${ }^{223}$, j'agitais mon étui de lunettes comme un hochet, en riant et gazouillant. Et, lorsque la bonne de ma pension de famille m'eut servi mon repas, je me versai des cuillerées de potage dans l'oreille avec l'ingénuité du premier âge." (IP, 1994, p. 88).

Como dissemos anteriormente, a ironia na sátira se inicia no descompasso entre o que afirma o narrador e o absurdo da situação. No caso, a crítica de France à voga de exaltação à pintura pré-rafaelita está por trás da ironia narrativa. Em primeiro lugar, o exagero da titulação nos que elogiam a arte do período, o eminente teórico e o esteta seráfico, indicam a inocuidade das análises de Silly. Em segundo lugar, o próprio nome Silly, uma explicitação da estupidez do esteta complementada pela associação com o comportamento infantil do crítico. Não há como não associar aqui a escolha do nome de Silly com a mesma nomeação do personagem do doutor Sili no conto Como o 'homem' chegou. A intenção sarcástica, e infantil, não poderia ser mais explícita. A crítica se situa na mesma chave do rebaixamento do outro, como vimos nos romances; desta vez, beirando a infantilidade. $\mathrm{O}$ absurdo da situação se torna mais explícito, acompanhando o tom crítico.

Ao fim do capítulo sobre a arte primitiva desses homens-pinguins, o narrador transcreve um texto de Tuckett, do imaginário "Bréviaire des esthètes", que o narrador descreve como o texto "plus sublime depuis les prophètes d'Israël”. Nele, Margaritone tem a trágica visão da arte renascentista na qual as figuras humanas parecerão pessoas normais, “on leur verra des corps". A visão dessa representação profana abala Margaritone que "mourut suffoqué par ce pressentiment horrible de la Renaissance ..." (p. 89-90). O humanismo estético de France atravessa a perspectiva do narrador, traduzido na ironia em relação aos comentadores da arte primitiva que sucumbem com a visão da arte renascentista, cujo foco central está na figura humana. A crítica de Anatole France em relação à arte primitiva dialoga, portanto, com a voga do primitivismo na

${ }^{222}$ A obra se encontra no National Gallery de Washington (Margaritone d'Arezzo, Madonna and Child Enthroned", 1270). É possível vê-la pelo site http://www.nga.gov/content/ngaweb/Collection/artobject-page.41622.html, acessado em 06/05/2013. Talfagar Square.

23 Segundo nota, a obra se encontrava à época no National Gallery de Londres, situado na 
França, mas também com a concepção de mundo do próprio autor, com o seu humanismo.

Do lado brasileiro, a leitura errática limabarretiana nos parece, da perspectiva crítica, um bom método de trabalho. Considerando a relevância do leitor na sátira, como sugerida por Hutcheons (1981), essa perspectiva poderá nos auxiliar não somente na compreensão do próprio ato de leitura limabarretiano, assim como nos ajudará a entender o caráter militante que Barreto atribuiu à obra de France, diferentemente de seus pares que viram no autor francês muito mais um modelo de erudição bienveillante. Nesse sentido, o estudo comparativo recupera e problematiza a presença de um autor como Lima Barreto no quadro mais amplo da literatura carioca de seu tempo. Há vários tipos de leitura e leitores, e o ato da leitura é fruto não só da materialidade da obra, como da condição social, do interesse pessoal e da época em que a obra se constrói. A leitura de Anatole France no Brasil de fins do século XIX e começo do XX foi bastante difundida pelos depoimentos e alusões que nos deixaram alguns autores ${ }^{224}$.

Nenhuma dessas leituras se aproxima da escrita militante que Lima Barreto faz da obra anatoliana. Isso sugere uma abertura da obra anatoliana. É possível pensar em pelo menos dois tipos de leitores potenciais de France: o leitor erudito que leva a sério mesmo as mais satíricas observações e o leitor errático que se permite transitar pela obra anatoliana detectando as provocações narrativas. Isso é possível pois ao mesmo tempo em que proliferam na obra de France referências das mais remotas e desconhecidas provavelmente resultado de anos de contato com os livros antigos da livraria de seu pai -, há sempre um jogo narrativo instigante que deixa no leitor uma ponta de desconfiança. Propomos que a leitura descompromissada e errática de Lima Barreto introduz um outro olhar para a obra de France, em oposição à recepção letrada corrente. Ele dialoga com o escritor francês como um irmão solidário diante do sofrimento alheio, como um humanista satírico.

${ }^{224}$ No terceiro volume de Trente ans de vie sociale, constam as conferências realizadas pelo autor no Brasil com uma breve descrição da recepção do escritor francês pelas cidades brasileiras do Rio de Janeiro e de São Paulo. A moda do "anatolismo" aludida por Augusto Meyer trata, não sem ironia, da grande voga do escritor francês em terras brasileiras, e obras como Ironia e Piedade, de Olavo Bilac, só confirmam a influência do epítome anatoliano. Barreto, por outro lado, avesso às modas literárias, ainda assim partilha da admiração por France, porém, por um France particular e peculiar construído quase como um personagem ficcional. Regina Salgado Campos (2000) trata da tentativa de recuperação crítica da obra de Anatole France nos anos 1940 com as edições de Trente ans de vie vociale. Para ela, porém, essa tentativa acaba fracassada, pois "o engajamento do intelectual proposto por Jean-Paul Sartre entretanto vai predominar nessa época, pois utiliza uma nova linguagem, e a escrita de Monsieur Bergeret [...] já não era mais adequada aos novos tempos" (Campos, 2000, p.112). 
Essa leitura errática de Barreto inspirou-nos também na análise de L'Île des pingouins. Partimos de um resumo geral da história da ilha de Alca, mas focaremos, agora, na relação entre a representação satírica e os acontecimentos políticos da França da era moderna: os rastros do boulangismo, o caso Dreyfus e o mundo intelectual dos pinguins. Essa leitura une as decepções de France e Barreto em relação ao "sonho republicano" e, do ponto de vista literário, aponta para um esgotamento do gênero romance como forma de denúncia social. Trata-se de mundos políticos e sociais lidos por meio de recursos literários e compreendidos a partir de olhares críticos e independentes em relação aos acontecimentos.

\section{Estórias exemplares}

A crítica ao mundo literário está presente nas duas sátiras. Na ilha de Alca, o mundo das letras se configura a partir do autor de De gestis Pinguinorum, Johannès Talpa $^{225}$. De um modo geral, a crítica se aproxima da paródia, no sentido de Propp, na inocuidade da manifestação espiritual. O tema do anticlericalimo em Anatole France aparece aqui parodiado, enquanto em L'Église et la République, o escritor elabora uma argumentação racional de denúncia da ligação entre o mundo político e o religioso. $\mathrm{O}$ tema se repete na obra anatoliana. Vejamos mais especificamente este processo na sátira, no lado anecdotique anatoliano, cuja inspiração, como indica nota de Bancquart, já se encontra no prefácio do primeiro volume da coletânea La Vie Littéraire. Nesse texto, dedicado ao diretor do Le Temps, Adrien Hébrard, France elogia o "esprit alerte" de Hébrard que permitiu a "une pensée recueillie, lente et solitaire comme la mienne" a realização da crítica literária do jornal. Logo nas primeiras linhas desse texto, France conta uma de suas estórias exemplares:

"Quel écrivain vous feriez, si vous aviez moins d'idées! Une magicienne russe, qui a longtemps vécu dans l'Inde, parle dans ses écrits d'un procédé qu'emploient les sages indous pour communiquer leur pensée aux profanes. À mesure qu'elle se forme en eux-mêmes, ils la précipitent dans le cerveau d'un saint homme qui l'écrit à loisir. Voilà un procédé qui vous conviendrait! (VL 1, 1925, p. II)

O elogio de France, como se dá nas suas melhores realizações, suscita a dúvida irônica no leitor. O exotismo da alusão à mágica russa, assim como a capacidade de comunicação mística dessa figura nos indicam que a pena satírica do narrador, sutil e de forma inteligente, soube realizar a proeza de revelar, escondendo. Essa habilidade

\footnotetext{
${ }^{225}$ Em português, o nome talpa é uma designação comum às toupeiras encontradas na Ásia e Europa.
} 
ludibriadora é o que existe de mais bem realizado na sátira dos pinguins e se assemelha às intervenções do narrador limabarretiano, como no caso da nobreza das Bruzundangas ou, como veremos, na estória exemplar retirada do conto Sua Excelência ${ }^{226}$. Além disso, o tom de anecdote (ou de estória exemplar) comporta uma dualidade fundamental na boa realização satírica que é a junção da perspectiva crítica autoral e narrativa, permitindo ao leitor vislumbrar, na ironia do narrador, os traços da crítica autoral, sem que essa ganhe relevância maior que a própria história. Essa mescla na narrativa aparece justificada no próprio texto laudatório em que France considera o bom crítico - assim como o bom escritor -, "celui qui raconte les aventures de son âme au milieu des chefsd'oeuvres" (VL1, 1925, p. III).

Vejamos o mesmo procedimento na descrição de Talpa, na recuperação que o narrador faz dessa história contada no artigo laudatório. No mesmo artigo citado anteriormente, ao tratar do amor de Hébrard aos livros, France recupera uma história de Gustave Doré $^{27}$. Doré ilustrou no século XIX inúmeras obras literárias, como a Divina Comédia de Dante Alighieri, e alguns contos de Charles Perrault. Segundo France, Doré criou "l'emblème ironique et touchant de ces existences que le culte des livres console de toutes les réalités douloureuses" (VL1, 1925, p. VI). Neste livro, encontramos a estória de Nestor, que escrevia em sua mesa enquanto ao seu redor seu país era massacrado pela guerra. France lê nessa história o símbolo dos bibliófilos destacados da realidade. Na história de Talpa, a situação se repete. Na escrita do Gesta Pinguinorum, o religioso, já velho, a redige em meio a uma guerra com os marsouins, que destruiram a terra dos pinguins. Enquanto o tom do prefácio laudatório continha uma ironia sutil, na narrativa dos pinguins a descrição é bem mais hostil, como nesse trecho no qual os marsouins invadem o monastério onde Talpa escrevia seu livro:

"L'air était chargé d'une âcre odeur de chair grillée; les cris de mort et les gémissements s'élevaient du milieu des flammes, et, sur le bord des toits croulants, des moines par milliers couraient comme des fourmis et tombaient dans la vallée. Cependant, Johannès Talpa

${ }^{226}$ Conto reunido em Histórias e Sonhos (2008).

${ }^{227}$ Célebre ilustrador do século XIX que estampou inúmeras obras literárias. A história do religioso Nestor ilustrada por Doré está em Histoire pittoresque, dramatique et caricaturale de la Sainte Russie, d'après les chroniqueurs et historiens Nestor, Nikan, Sykvestre, Karamsin, Segur, etc. etc. etc., commentée et illustrée de 500 magnifiques gravures par Gustave Doré, sous la direction générale de Soutain, graveur de l'histoire de Russie, de batailles, de portraits, de paysages, de genre, de fleurs, d'animaux, de crustacés et de plantes rares. Consultamos a edição disponível na Faculdade de Arquitetura e Urbanismo da Universidade de São Paulo, de onde tiramos a ilustração abaixo. A edição é de 1824 e é uma obra que satiriza, como a Ilha dos Pinguins, a história da Rússia. A autoria é certamente de Doré, considerando a irônica profusão de nomes de autores imaginários na referência. 


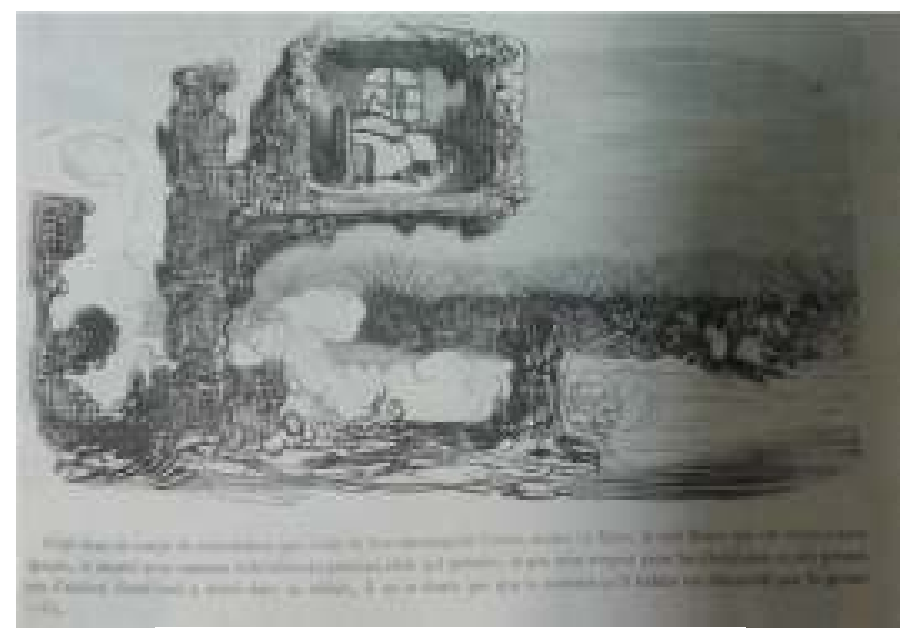

Ilustração de Nestor por Gustave Doré

No trecho, o caráter de denúncia fica mais explícito. O escritor, descolado de sua realidade, foge do mundo, e em sua torre de marfim, continua o trabalho solitário sem observar ao menos o que se passava ao seu redor. Mais à frente, ao tratar dos cafards, nome dado àqueles que se colocavam à distância dos acontecimentos do affaire de quatre-vingt mille bottes de foin ${ }^{228}$, é a mesma posição descolada do real que o narrador critica. Porém, enquanto aqui a denúncia está permeada pela imaginação, mais bem realizada, na crítica aos cafards, o aspecto autoral ganha maior representatividade. Sabemos, pela biografia de France, que a censura se dirige aos seus próprios desafetos durante o embate pela revisão do processo Dreyfus.

Retomando a história de Talpa, ao fim do embate, só restava da abadia a sua célula, e "le vieux chroniqueur écrivait encore" (IP, 1994, p. 85). O narrador trata então do estilo de escrita do religioso. Ele afirma que, ao consultar o material para pesquisa, a escritura era difícil de ser decodificada, mas que o estilo de Talpa não apresentava a marca de nenhuma emoção; a narrativa era rápida e de uma concisão que "va parfois jusqu'à la sécheresse", com raras e judiciosas reflexões. Novamente, o anedotário incorpora a função crítica do narrador. A censura, porém, não se direciona somente ao descolamento do real, mas à incapacidade imaginativa de Talpa, aspecto cognitivo muitas vezes censurado pelo narrador anatoliano.

É possível observar nessa história os traços de mudança de perspectiva, da suavidade irônica à sátira, que bem sintetiza as transformações observadas na obra

\footnotetext{
${ }^{228}$ Trataremos logo à frente desta represtação satírica do caso Dreyfus.
} 
anatoliana. A progressiva imersão do autor nas questões de seu tempo acompanha essa modificação. A estranheza desse afastamento do real enquanto escreve sobre ele é notada pelo narrador, que sugere que a contenção de espírito de Talpa poderia parecer excessiva "chez un annaliste qui s'applique à rapporter les faits accomplis de son temps" (IP, 1994, p. 85). No uso das estórias exemplares, vemos a transformação do narrador anatoliano, do suave ironista ao contumaz crítico da sociedade francesa. E a posição desse narrador acompanha a trajetória do intelectual France que passa da idiossincrasia livresca, marcada na históra pelo alheamento face a um mundo assombrado pela guerra, para uma literatura que dialoga com o seu tempo, uma literatura militante nos termos limabarretianos.

No caso da literatura dos Bruzundangas, a narrativa em primeira pessoa confunde ainda mais a perspectiva do narrador e do autor. No tratamento dos samoiedas, os literatos da Bruzundanga, a primeira ressalva desse autor-narrador é em relação à dificuldade da língua dos literatos importantes de lá, uma língua particular, diferente da usual, mas considerada pelos solenes literatos a "lídima", pelo simples fato de "ter feição antiga de dous séculos ou três" (Bru, 1956, p. 31). A apresentação da literatura dos Bruzundangas é o motivo para o autor-narrador afirmar a sua própria concepção da arte literária, de acordo com o entendimento proposto no texto escrito para a sua frustrada palestra na cidade de Mirassol. Para o narrador de $O s$ Bruzundangas, assim como para o autor de $O$ destino da literatura, a arte literária contribui para o auto-conhecimento e para "nos ligarmos em sociedade, em humanidade, afinal" (p. 32). O primeiro alvo da crítica ao mundo literário do país da Bruzundanga é, portanto, aos respeitados literatos que escrevem numa língua incompreensível, cujas obras nunca poderiam alcançar o nobre objetivo da literatura militante defendida por Lima Barreto. Duas instâncias se confundem logo nas primeiras páginas da sátira, o ficcional mundo literário e a concepção autoral da literatura.

Nesse mesmo capítulo, o autor-narrador transcreve um conto popular. Trata-se, na verdade, de um dos contos publicados na coletânea Histórias e Sonhos, com o mesmo título de Sua Excelência ${ }^{229}$. No dito conto, um cocheiro sonha ser um agaloado ministro que, saindo de um baile, é guiado em alta velocidade por um condutor que mais se assemelha ao diabo, um homem "de nariz adunco, queixo longo com uma

\footnotetext{
${ }^{229} \mathrm{Na}$ sátira, o narrador afirma, porém, que na versão dos populares das Bruzundangas, o conto se intitularia "O General e o Diabo", com a variante "O Padre e o Diabo". Diz ainda que a história que ali transcreve apresenta-se "muito desfigurada" em relação à "versão mais geral".
} 
barbicha" (p. 34). O ministro, que até então permanecera entorpecido pela reação do auditório do baile às suas palavras, finalmente, percebendo a alta velocidade do carro enquanto o relógio continuava a marcar o horário da saída da festa, grita para que o cocheiro pare ${ }^{230}$. Sem ser atendido e sofrendo com o calor que aumentava, vai tirando a vestimenta até que sufocado, desmaia. Quando acorda, está vestido "com uma reles 'libré' e uma grotesca cartola" (p. 35), direciona-se a um homem “com as mesmas magníficas grã-cruzes" e lhe oferece a condução. Como num simulacro do real, a inversão de papéis revela aos olhos do leitor a aparência enganosa e injusta da realidade. O agaloado ministro é uma caricatura de si mesmo do alto de sua soberba, de quem nada sobra se retiradas as honras da vestimenta, enquanto o cocheiro-diabo simula a conversão do mundo dos vivos para o mundo dos mortos ${ }^{231}$, invertendo a ordem das coisas para denunciar o vazio da aparência.

É depois dessa estória exemplar que conhecemos a escola Samoieda, uma "curiosa escola literária" que caracteriza a literatura da Bruzundanga, na qual "os literatos simulam sê-lo para ter a glória que as letras dão, sem querer arcar com as dores, com o esfôrço excepcional, que elas exigem em troca" (Bru, 1956, p. 36). Como no simulacro do real na história do ministro agaloado, aqui também a simulação dos literatos ressalta a desconexão com o real ao reforçar o absurdo da situação narrada. Cruzam-se a perspectiva narrativa, a simulação dos literatos de lá, com a perspectiva autoral da literatura que interpreta a arte como uma atividade dolorosa para o criador. Essa perspectiva cruzada recai novamente sobre o olhar autoral no longo trecho no qual o narrador opõe aquilo que considera a verdadeira literatura que impele a "ir ao âmago das cousas", em oposição ao simulacro da literatura de fachada. Não é uma literatura que se opõe à "lídima" arte de lá, é a verdadeira literatura que se opõe ao simulacro das Bruzundangas. Nessa comparação, não somente voltamos ao cruzamento narrativoautoral, como podemos observar o viés moral da narrativa que, criando um simulacro do real, busca negar essa simulação e afirmar a verdadeira literatura. A literatura da Bruzundanga é um simulacro enquanto a literatura limabarretiana seria a verdadeira.

${ }^{230}$ Mais uma vez, temos o descolamento do mundo e o estupor frente à realidade.
${ }^{231}$ Parece-nos existir aqui algo da carnavalização que Bakhtin estudou a partir de Rabelais e Dostoiévski. Do ponto de vista da crítica nacional, um recente artigo do filósofo Marcus Nobre (2012) publicado na revista Piaui faz um panorama da discussão entre o arcaico e o moderno no país desde os movimentos intelectuais da Primeira República. Ao nosso ver, a literatura militante de Lima Barreto pode contribuir muito para essa discussão remanescente na crítica nacional. 
O tom amargo da crítica anatoliana que vimos acima se aproxima desse moralizador narrador limabarretiano, que olha o outro com desdém e a realidade com desconfiança. Escárnio e deboche se associam no satírico moralista para lidar tanto com o satirizado, rebaixando-o, como com o universo em que vive esse literato. Troça e crítica, moralismo, oscilação entre autor e narrador, ou entre comentário e estória exemplar, essas são algumas das características da escrita satírica presentes tanto na escrita de Lima Barreto como na de Anatole France. No caso de Barreto, porém, para vislumbrar os procedimentos de composição desse universo anedótico e moralista, é necessária uma confrontação adicional entre os textos satíricos e outras crônicas para tratar do embate entre o real e o ficcional, já bem enunciado por Maire-Claire Bancquart na obra de France.

No centro do deboche limabarretiano está a nomeação dos representantes dos samoiedas, particularmente no tom onomatopeico das denominações. O chefe dos samoiedas é o príncipe "Tuque-Tuque Fit-Fit" que, como os pinguins, vem de uma região polar e viveu nas margens do Ártico, na Sibéria, alimentando-se de mamutes. Tanto o deslocamento espacial como o efeito cômico e infantil da nomeação do príncipe buscam descolar a relação entre o Brasil e o país das Bruzundangas, criando uma distância enganadora. Enganadora pois, no cotejamento com outras crônicas limabarretianas é possível perceber o mesmo caráter denunciador pelo exagero, com outra roupagem. A região polar escolhida pelo narrador é análoga a matriz grega da crítica limabarretiana que o escritor denuncia na literatura de seus pares. A alusão à Grécia aparece, de fato, depois da descrição do tal príncipe, possuindo os samoiedas, uma "civilização digna da Grécia Antiga" (Bru, 1956, p. 38). O escritor Coelho Neto é inúmeras vezes associado ao modelo grego em crônicas limabarretianas, e a função do exotismo das comparações limabarretianas é sempre a mesma: enfatizar o estranho para desmascarar o real. Na crônica Histrião ou literato?, publicada em 15 de fevereiro de 1918, na Revista Contemporânea, o narrador diz que Coelho Neto "nunca pôde perceber que nós hoje não podemos sentir como a Grécia e que os seus deuses nos são estranhos perfeitamente e quase incompreensíveis" (TC1, 2004, p. 318). Viver num mundo distante no tempo e espaço só deixa marcado no literato a constante fuga do real, em oposição à literatura militante de Barreto.

A crítica ao amor pelas coisas da Grécia está na mesma chave do antiamericanismo, do anticlericalismo e dos estrangeirismos de todo o tipo, todos eles 
elementos introduzidos artificialmente no seio da sociedade, cuja verdadeira face nunca é realmente vista, a pobreza e o sofrimento das pessoas comuns. Essa inspiração que descola o escritor de sua realidade e sociedade não faz mal somente à inspiração literária, como à própria literatura, segundo o escritor. Da denúncia dessa artificialidade, surge a explicitação satírica da dissimulação literária dos samoiedas. É como se a sátira limabarretiana construísse um simulacro do real que se passa pela realidade, ao mesmo tempo ocultando e denunciando-a. A narrativa desvenda pela negação - ou seja, pelo distanciamento maior do real -, enquanto o autor-narrador denuncia, moralizando a narrativa ao revelar, nos comentários, o verdadeiro.

Nessa outra realidade, os personagens, as referências e as histórias exemplares são em geral as mais bizarras e distantes possíveis. A principal fonte que o narrador consegue achar sobre os samoiedas é um livro do inglês H.T. Switbilter, Literature of the Stingy Peoples, no qual se encontrariam alguns versos samoiedas anônimos. Assim como no caso de Sili, o nome do professor de Bristol, Switbilter, sugere a mistura de sweet (swit), doce, com bitter (bilter), amargo, um equivalente à combinação entre troça e crítica que tratamos anteriormente. Além disso, o povo da Bruzundanga é chamado de povo mesquinho (stingy people), crítica que, por ser escrita numa língua estrangeira, adequa-se à linguagem incompreensível dos samoiedas, que ninguém entende, mas parece culto, distinto. A crítica em si aos versos samoiedas aparece logo depois. Para Switbilter, eles são enfáticos, "sem quantidade de sentimento ou um acento musical agradável e individual, descaindo quase sempre para a melopéia ou para o "“tantã' ignaro" (Bru, 1956, p. 39). Da troça à crítica, ou do doce ao amargo. Estamos próximos à ironia e piedade anatolianas. Há na sátira limabarretiana, uma espécie de dosador crítico que equilibra a escárnio e julgamento, e, assim como no estórias exemplares anatolianas, é nessa chave que o humanismo satírico se revela.

A origem dos nomes na sátira limabarretiana pode ir além do onomatopéico "Tuque-Tuque Fit-Fit" ou da mistura de Switbilter, como é o caso do mestre dos samoiedas, um "tal Chamat ou Chalat, um aventureiro francês ...” (Br, 1956, p. 39), criador da poética da Bruzundanga. O nome Chamat, segundo Antonio Arnoni Prado teria como mote a "panacéia do xamanismo", seita religiosa de tribos da Sibéria e Mongólia, nome usado na sátira como uma crítica à pompa bacharelesca dos medalhões literários contemporâneos a Barreto, "um modo erudito de banalizar a erudição, 
convertendo-a em farsa ao transformá-la em manifesto" (Prado, 1989, p. 38) ${ }^{232}$. Esse Chamat ou Chalat, afirma o satirista, esteve com Flaubert no Egito, onde "se ocupava nos ócios de sua provável medicância em rimar uma tragédia clássica" (Br, 1956, p. 39). Num livro sobre as memórias literárias de Flaubert e outros escritores, Maxime du Camp conta que o criador de Madame de Bovary realmente descobrira no Cairo um homem chamado "Akim-Bachi, médecin-major, Français d'origine, ancien officier de santé, nommé Chamas" (Du Camp, 2002, p. 114), que chamara a atenção de Flaubert pela sua estupidez e pelo fato dele escrever tragédias. A descrição de Lima Barreto no seu diário íntimo é exatamente como apresenta du Camp:

"Quando Flaubert esteve no Egito, encontrou um certo Chamas, francês de origem, que, de aventura a aventura, havia chegado a ser médico-em-chefe do exército quedival. Esse medicastro empregava o seu ócio em rimar uma tragédia clássica, intitulada Abd-El-Káder, em cinco atos, cujo verso mais citado por ele era o seguinte: "C'est de là, par Allah! Qu"abd'Allah s'en alla”! (PS, 2006, p. 1299).

No diário, Barreto refere-se também à harmonia imitativa dos antigos, como o faz du Camp ao dizer que quanto mais idiotas eram as composições de Chamas, mais Flaubert aplaudia, estimulando o criador de tragédias. A situação, assim como a de Voltaire, que aparece logo em seguida, funciona como anedotário da estupidez samoieda. O inusitado das referências do narrador surpreende mais uma vez com o caso da recepção da obra do aventureiro francês que "foi um louco sucesso de riso muito parecido com o do Tremor de Terra de Lisboa, aquela célebre tragédia do cabeleireiro André, a quem Voltaire invejou e escreveu [...] que continuasse a fazer sempre cabeleiras" (Br, 1956, p. 40). Existe de fato um antigo provérbio de Voltaire que diz "Faites des perruques, maître André, faites des perruques" 233 . Trata-se de uma carta do pensador francês, na qual ele comentava uma tragédia em cinco atos e em versos escrita pelo peruqueiro Charles André, em 1760, intitulada Le Tremblement de terre de Lisbonne. André teria enviado a peça para a apreciação de Voltaire, que, depois de lê-la, respondeu ao peruqueiro com a repetição constante da frase "Maître André, faites des perruques", aconselhando-o a abandonar a atividade literária pelo insuficiente talento.

${ }^{232}$ A crítica de France à voga do primitivismo na França nos parece ser equivalente do ponto de vista do posicionamento do narrador diante do seu ambiente artístico e cultural.

${ }^{233}$ As informações sobre a origem desse provérbio e sua história estão em Larousse, Pierre. Grand dictionnaire universel du XIXe siècle. Tome 1. 1867-1890. Collection : Archives de la linguistique française ; 225, bnf.fr. On-line em Gallica desde :15/10/2007, acessado em 14/12/2012. O tremor de terra em Lisboa também é tematizado em Candide, de Voltaire. 
Tanto a história jocosa de Flaubert como o conselho de Voltaire estão na mesma chave de conversão da erudição em farsa para transformá-la em manifesto.

No jogo de inspiração exemplar do satirista, que não se esgota na ficcional relação com Flaubert e na alusão ao provérbio de Voltaire, Chalat (ou Chamat) teria ainda afrontado a crítica e "não podendo defender-se com os clássicos franceses", escolheu algo mais remoto, como a poesia na língua dos samoiedas, "que conhecia por ter trabalhado como marinheiro de um baleeiro que naufragou nas proximidades da terra dêsses lapões" (Bru, 1956, p. 40). O conhecimento dessa literatura "das margens do glacial Ártico" logo garantiu a Chamat o reconhecimento nas Bruzundangas. As informações acerca do aventureiro francês repetem incessantemente a farsa criada pelo narrador que enfatiza a cada nova referência a vacuidade da origem literária da Bruzundanga, como um retrato em relevo do Brasil.

A farsa se torna manifesto pela recorrência a um mesmo recurso de hipérbole do exótico e do pensamento circular que a envolve ${ }^{234}$. O narrador descobre, por exemplo, que Chamat (ou Chalat) conhecera a obra de Switbilter, a partir de fragmentos de um tratado poético do aventureiro francês, "citado na tradução da obra de um seu discípulo basco por onde os 'samoiedas' da Bruzundanga estudaram a escola que verdadeiramente Chalat ou Chamat fundara". As referências sinuosas só enfatizam ainda mais a artificialidade dessa literatura que busca uma origem nobre. Ao se contrapor à literatura dos samoiedas, o manifesto de Barreto não somente denuncia o seu vazio, como propõe que algo novo prescinda de uma origem nobre para se legitimar. A sátira das Bruzundangas é, nos seus melhores momentos, um manifesto de oposição ao antigo e de criação do novo.

$\mathrm{Na}$ criação desse novo, o manifesto satírico de Barreto adquire em certos momentos tons mais críticos e duros, apresentados usualmente a partir dos comentários do narrador que se contrapõe a essa literatura de fachada. Para ele, não era possível tirar dessa literatura nenhuma "concepção geral e larga de arte", o que os fazia perder a "sua função natural que supõe sempre a obra literária como fim” (p. 41). Nesse manifesto satírico, o julgamento da arte dos samoiedas interrompe a comicidade das estórias exemplares para julgar a arte literária daquele país pelos critérios autorais. A oscilação entre a chacota e o comentário crítico se repete constantemente nas impressões do

${ }^{234}$ Lembrando aqui o elogio irônico e a tautologia do narrador anatoliano ao comparar a arte primitiva à arte francesa. 
narrador, sendo que a escolha destas estórias se apresenta como motivo risível para tratar de coisas sérias, "troça e simplesmente troça, para que tudo caia pelo ridículo" (CRJ, 1956, p. 119). A troça se converte em manifesto com a incorporação da visão autoral da literatura.

Outra dessas estórias exemplares seguidas do comentário do narrador merece atenção analítica. Ainda na chave do exotismo denominativo e muito semelhante ao diálogo entre Jean Coq e Jean Mouton contado pelo senhor Bergeret. O narrador descreve, no final do trecho sobre os samoiedas, uma conversa entre alguns poetas da Bruzundanga, "adeptos extremados da Escola Samoieda" (Bru, 1956, p. 42). Nesse diálogo, encontra-se grande parte dos fundamentos críticos do próprio Barreto aos literatos do Brasil, transpostos satiricamente. O primeiro elemento satírico vem novamente dos nomes dos poetas, Kotelniji, Wolpuk e Worspikt, nominata exótica que busca se distanciar da matriz real com a prevalência do uso de consoantes no lugar dos nomes usuais brasileiros, mais compostos de vogais.

O segundo elemento é temático e formal. Os poetas samoiedas discutem num bar a poesia de um deles, Worspikt, que "tratava de lua, de iceberg". Assim como o uso de uma vestimenta "à moda da Sibéria" em um país que fica "nas zonas tropical e subtropical", também a inspiração nos icebergs se encontra desconectada da realidade daquele país. Quanto à rima e ao ritmo da narrativa samoieda, o satirista enfatiza o caráter repetitivo da arte de lá, como no trecho transcrito e elogiado por Kotelniji: "há luna loura linda leve, luna bela!” (p. 43). A resposta do autor da poesia explicita a fonte da rima, dizendo que ele nada mais fez do que imitar Tuque-Tuque no verso "Loga Kule Kulela logalam". O diálogo versa então sobre as regras poéticas, particularmente sobre a ênfase em cada uma das vogais como opção para a tônica do verso de Worspikt. Porém, é à Kotelniji que a retomada crítica do narrador se dirige ao fim. Kotelniji era considerado um grande poeta samoieda e teria estabelecido as leis da escola perfeita, as mais bizarras possíveis, como a de que a poesia deve ter como principal função provocar o sono. Cotejando a narrativa satírica com as crônicas de Barreto, as características de Kotelniji são muito semelhantes às atribuídas a Coelho Neto, novamente um dos alvos preferenciais de Lima Barreto. Em Qualquer coisa, de $1911^{235}$, Barreto revela sua incompreensão da literatura do autor de $A$ Conquista: 89).

${ }^{235}$ Crônica publicada em 24-6-1911 em A Estação Teatral e consultada em TC1 (2004, p. 88- 
"Não posso compreender que a literatura consista no culto ao dicionário; não posso compreender que ela se resuma em elucidações mais ou menos felizes dos estados d'alma das meninas de Botafogo ou de Petrópolis; não posso compreender que, quando não for esta última coisa, sejam narrações de coisas de sertanejos; não posso compreender que ela não seja uma literatura de ação sobre as idéias e costumes; não posso compreender que ela me exclua dos seus personagens nobres ou não, e só trate de Coelho Neto; não posso compreender que seja caminho para se arranjar empregos rendosos ou lugares na representação nacional; não posso compreender ..." (TC1, 2004, p. $89)^{236}$.

A desconexão da realidade e o caráter repetitivo da arte, características ironicamente atribuídas aos poetas samoiedas, aparecem aqui no culto ao dicionário, na elucidação dos estados d'alma das meninas de Botafogo ou Petrópolis, características incompreensíveis diante do tipo de literatura a que Barreto se propõe. Guardadas as devidas proporções, a incompreensão de Barreto nos remete à reação de Anatole France aos poemas de Malarmé e Verlaine, rejeitados pelo criador de Coignard para o terceiro volume da Parnasse Contemporain, em função da obscuridade das obras. Essa incompreensão das poesias dos simbolistas foi ressaltada por Bancquart: "Anatole France ne comprend pas. Cette langue dégagée de la syntaxe, cette suggestion par le son, cette dissolution de la forme sonnet: il ne comprend pas" (Bancquart, 1984a, p. 90). Os excessos formais parecem estranhos aos dois autores, seja no culto ao dicionário ou nas elucidações dos estados d'alma, seja na solução sonora ou na dissolução da forma soneto. Tanto a clareza anatoliana como a literatura de ação em Barreto nos coloca frente a uma compreensão da arte que comunique alguma mensagem, algum sentimento, alguma moral. A arte de Barreto e France é, essencialmente, combativa ${ }^{237}$.

Isso porque mais do que a polarização com seus pares e contextos, a literatura de ambos está fundada numa concepção humanista do homem, que envolve um saber

${ }^{236}$ A sugestão da figura de Coelho Neto como inspiradora para Kotelniji também pode ser lida a partir da crônica Literatura e Política, de 1918, publicada em A Lantera, de 18-1-1918, na contraposição entre a literatura contemplativa de Neto e a militância literária de Barreto. Ou mais explicitamente na já citada Histrião ou literato?, na qual Coelho Neto é descrito como "o sujeito mais nefasto que tem aparecido no nosso meio intelectual" (TC1, 2004, p. 318). A descrição do grande poeta samoieda não é menos mordaz, já que Kotelniji (ou Coelho Neto) "de todos os postiços literários, usava, e de tôdas as mesquinhezas da profissão, abusava” (Bru, 1956, p. 45). A frequência com que Lima Barreto se refere criticamente a Coelho Neto nas crônicas já seria suficiente para fortalecer a associação entre o grande poeta samoieda e o autor de $A$ Conquista, obra cuja grafia lembra a revista $A$ Kananga, de Koteljini, segundo o satirista “órgão de casas de perfumarias, leques, luvas e receitas para doces".

${ }^{237}$ Se em Barreto, o caráter combativo é inegável, no caso de Anatole France, é preciso reforçar que as querelas fazem parte de sua história no mundo das letras e da política, desde os embates com os parnasianos, passando pelos debates com Bourget e Brunetière, até o caso Dreyfus e todas as questões subsequentes reunidas na coletânea de Vers les temps meilleurs, como a oposição ao colonialismo, o viés socialista e o apoio às universidades populares. 
crítico voltado para um conhecimento mais amplo e para uma cultura que seja capaz de desenvolver as suas potencialidades. Diante dessa compreensão do mundo, o título da coletânea dos textos de intervenção de France, Vers les temps meilleurs, não poderia ser mais adequada. $\mathrm{O}$ ponto alto das sátiras no conjunto das obras de ambos reside na contradição que se apresenta entre o projeto humanista de um futuro melhor e a constatação da sua impossibilidade. Nos seus melhores momentos, tanto a sátira dos pinguins como a do país da Bruzundanga fazem aflorar essa contradição, principalmente quando articulam literatura e manifesto sem qualquer solução salvacionista. A junção entre a troça narrativa das pequenas e inusitadas estórias exemplares e a crítica autoral é o procedimento fundamental dessa literatura de combate com as palavras. Além disso, observamos a utilização sistemática de recursos como os nomes e lugares exóticos e o diálogo constante com os respectivos ambientes literários. No intuito de examinar o êxito (ou o fracasso) dessa narrativa de combate, trataremos da transposição do caso Dreyfus para a sátira no "affaire des quatre-vingt mille bottes de foin" para em seguida observar a concepção do mundo futuro em France e Barreto e nos aproximar de uma definição mais precisa desse humanismo satírico.

\section{L'affaire des quatre-vingt mille bottes de foin}

A história moderna da ilha de Alca apresenta-se dividida em quatro livros. No primeiro, temos a época de Aegidius Aucupis, "l’Érasme des Pingouins", seguida da de Trinco, que corresponde ao período napoleônico, e enfim a República, descrita pelo professor Obnubile. No segundo livro, o narrador trata do mundo clerical, nas figuras dos padres Agaric ${ }^{238}$ e Cornemuse ${ }^{239}$, e da tentativa de restabelecer a monarquia com o retorno do príncipe Crucho, o mesmo príncipe Gamelle dos trublions. No mesmo livro, o mundo religioso se entrelaça com a política na integração do general Chatillon, que representa o general Boulanger. Toda a narrativa segue um procedimento semelhante de concentração da história, com inúmeros trechos explicitamente inspirados no estilo rabelaisiano.

No livro do "l'affaire des quatre-vingt mille bottes de foin", a história do caso Dreyfus é de tal forma reduzida que em aproximadamente quarenta páginas o narrador

\footnotetext{
${ }^{238}$ Segundo Bancquart, Agaric pode ser tanto o padre du Lac, jesuíta e reitor da escola SainteGeneviève de Paris, em 1872, ou o padre Bailly, assuncionista e diretor do jornal La Croix, jornal fortemente antidreyfusard.

239 Trata-se de um cartuxo, da ordem austera fundada por São Bruno e que, segundo Bancquart foram suspeitos de terem financiado a campanha antidreyfusard.
} 
trata desde a primeira condenação do capitão judeu em 1894 até o momento posterior à reabilitação de Dreyfus, em 1906, com um trecho final que trata do desapontamento do narrador - fortemente autoral - frente ao rumo tomado pelos acontecimentos. Os personagens chaves do caso são apresentados sinteticamente ao leitor. Primeiramente, o general Greatauk, duc du Skull, o mesmo que fundara a propriedade na base da força, e que exerce, durante o caso, a função de ministro da Guerra ${ }^{240}$. Como foram vários os militares na função, a figura de Greatauk descreve mais uma atitude bélica; um tipo que combina as particularidades dos diversos militares que ocuparam o cargo durante o caso Dreyfus. É possível pensar por exemplo no general Mercier, responsável pela prisão de Dreyfus em outubro de 1894, ou no general Billot, autor da queixa contra Zola em 1898. O personagem principal, Pyrot, é Dreyfus, nome de raiz grega que segundo Bancquart significa "celui qui met le feu". O terceiro personagem é o general Panther, “chef d'état major", que tudo indica se tratar da representação do comandante Henry ${ }^{241}$, grande responsável pela produção de documentos falsos para incriminar Dreyfus. Segundo nota, o nome é um empréstimo irônico de uma sátira do mundo clerical de 1799, La Guerre des Dieux, de Évariste Parny, cujo primeiro canto se intitula "Histoire du juif Panther".

$\mathrm{Na}$ descrição de Greatauk, France parece ter se inspirado na carta de Zola, J'accuse. A desconfianaça do ministro da Guerra em relação ao judeu Dreyfus é assim descrita: "il (Greatauk) lui (Dreyfus) reprochait son zèle, son nez crochu, sa vanité, son gout pour l'étude, ses lèvres lippues et sa conduite exemplaire" (IP, 1994, p. 148). Na carta, Zola afirma: “Dreyfus sait plusieurs langues, crime; on n'a trouvé chez lui aucun papier compromettant, crime; il va parfois dans son pays d'origine, crime; il est laborieux, il a le souci de tout savoir, crime; il ne se trouble pas, crime; il se trouble, crime". Apesar de seguir uma lógica semelhante a de Zola, ressaltando as características do acusado mais do que provas de sua culpa ou inocência, os elementos elencados por France ressaltam mais a figura de Pyrot do que as suas qualidades morais, caricaturizando, assim, o personagem. Além disso, enquanto na carta de Zola, a intenção era criar um mundo dual no qual Dreyfus era a vítima ${ }^{242}$, na sátira dos

240 Como é possível notar, a cronologia não tem grande relevância na obra. O mesmo personagem dos tempos antigos aparece sem maiores explicações nos tempos modernos.

${ }^{241}$ Se compararmos a narrativa de France ao J'accuse, de Zola, Panther poderia também ser du Paty de Clam, o grande criador do caso segundo o autor de Germinal.

${ }^{242}$ Ver interpretação em Almeida (2009). 
pinguins, o ridículo e o exagero são ressaltados com o fim de denunciar o absurdo da situação.

Aqui, o caso melodramático construído por Zola se transforma no patético caso dos oitenta mil fardos de feno ${ }^{243}$, remessa destinada à cavalaria francesa, que havia desaparecido. Era esse o crime de guerra de Pyrot. A insignificância do crime e a impossibilidade real de roubar uma carga desta dimensão só aumentam o efeito satírico, convertendo, como em Lima Barreto, a farsa em manifesto, em denúncia. A frase que o general Panther repete constantemente caracteriza bem todo o processo: "Ce procès est un chef-d'oeuvre. Il est fait de rien" (IP, 1994, p. 155). É nesse espaço não preenchido e ampliado que a representação satírica do caso Dreyfus na Ilha dos Pinguins se diferencia da carta de Zola e também dos trublions. Apesar da narrativa dos pinguins seguir em alguns momentos a lógica maniqueísta de J'accuse e em parte dos trublions este na cisão do mundo em dois mundos paralelos - a desilusão final rompe com o mundo dual e o panfletário converte-se em manifesto do desencanto. Portanto, é no vácuo criado entre o exagero das caracterizações e o vazio da situação que o satirista dos pinguins cede espaço ao desencanto.

Voltando aos personagens do caso dos oitenta mil fardos de feno na sua relação com a trama real do caso Dreyfus, temos ainda: o conde de Maubec de la Denttulynx como Esterhazy, o verdadeiro culpado pelo crime imputado a Dreyfus; Robin Mielleux como Jules Méline, primeiro-ministro que declara durante o processo contra Zola não existir um caso Dreyfus. Mielleux é descrito por France como um "homme doux aux riches et aux puissants et dur aux pauvres gens, de petit courage et ne connaissant que son intérêt" (p. 156). Colomban é certamente Zola, "un petit homme myope", autor de 160 volumes de sociologia pinguim, que sai em defesa de Pyrot, primeiramente colando placas nas ruas, depois compondo "un mémoire où il exposait clairement que Pyrot n'avait pu voler au ministère de la Guerre quatre-vingt mille bottes de foin qui n'y étaient jamais entrées, puisque Maubec ne les avait jamais fournies ...” (p. 159). Le mémoire é uma clara alusão a J'accuse.

Logo depois da publicação do mémoire de Colomban, o defensor de Pyrot é levado ao Tribunal, onde Greatauk, chamado a depor, afirma: "Je jure que Pyrot est um scélérat". Essa declaração aponta para o que chamamos a atenção anteriormente: a concentração da narrativa, que se dá tanto do ponto de vista temporal, como no que diz

${ }^{243} \mathrm{Na}$ tradução de João Guilherme Linke, de 1986. 
respeito aos personagens. No caso dos personagens, trata-se da dualidade localuniversal, em que os agentes caracterizam pessoas reais ao mesmo tempo que representam tipos universais. Podendo ser atribuída a diferentes agentes e momentos da história real do caso Dreyfus, a declaração, por exemplo, sintetiza a reação dos antidreyfusards que ou negam a existência do caso ou reafirmam a culpabilidade se amparando apenas na autoridade. Ao mesmo tempo, algumas declarações se aproximam do conteúdo específico, como quando o general Cavaignac, ministro da Guerra, afirma, no Tribunal, estar certo da culpabilidade de Dreyfus ou quando o coronel Henry declara publicamente a culpabilidade do capitão judeu, garantindo possuir outros documentos secretos comprometedores.

Como vimos, esta é uma característica do humanismo satírico que se repete: a dualidade entre a representação particular dos personagens, ligada ao contexto do caso Dreyfus, e seu conteúdo universal e humano. Do ponto de vista da narrativa, esta característica está diretamente ligada à perda de importância do herói intelectual. $\mathrm{O}$ embate pela palavra que estava no cerne de J'accuse e da Histoire Contemporaine, com esta figura organizadora e comentadora dos acontecimentos, já não tem mais a mesma força. Enquanto na série anatoliana, o personagem central, Bergeret, é o detentor da sabedoria que trabalha a favor de Dreyfus, aqui, não existe mais a figura de um intelectual com esse poder. Colomban está sempre acuado com a reação violenta da população e o sábio Bidault-Coquille retorna, como veremos, para sua torre de marfim. Esse poder da palavra que teve como auge a publicação de $J$ 'accuse, vai perdendo força com o distanciamento temporal dos acontecimentos, assim como com o rumo dos mesmos.

Enquanto Zola pintara um quadro da situação diante da imprecisão das informações, como um pintor impressionista, a sátira anatoliana desenha uma imagem condensada e distorcida do real, repleta de personagens caricaturizados e retratada a partir de momentos chave dos acontecimentos; um quadro distorcido. Talvez, esta nova posição do narrador seja resultado de uma percepção mais distanciada do auge dos acontecimentos, e a opção pela satirização do real seja resultado deste distanciamento, uma forma particular de enfatizar o absurdo dos acontecimentos. Neste sentido, é importante fazer uma diferenciação em relação ao exagero limabarretiano. $\mathrm{O}$ procedimento em Lima Barreto figura como manifesto também contra a própria linguagem e contra o ambiente literário e político do escritor brasileiro. Já as 
deformações na sátira anatoliana não se voltam para a própria literatura, mas para o mundo social do autor. Não é um ataque à palavra, mas pela palavra que perdeu sua força ancorada na figura do intelectual.

Esse ponto de enunciação do discurso não é, porém, menos radical, pois a posição do autor se mostra ainda mais aguerrida em alguns momentos. Seja em relação àqueles que não tomaram partido durante os acontecimentos, aos "cafards qui, de peur de coups, se tenaient à distance égale des deux camps" (IP: 1994, p. 181), seja na defesa amargurada da inocência poética do sábio Bidault-Coquille. Sobre esse personagem, que Bancquart sugere ser a representação do próprio autor, afirma o narrador: “... substituant à la réalité multiple et vulgaire une poésie simple et magnifique, il se représentait l'affaire Pyrot sous l'aspect d'une lutte des bons et des mauvais anges ..." (p. 182). A relação entre o personagem e Anatole France, porém, não nos parece isenta de controvérsias. Bidault-Coquille poderia também representar o próprio Zola ou outros nomes envolvidos na defesa de Dreyfus. Esta suspeita nos parece verossímil a partir de uma nota da própria Bancquart que afirma que a amante de Coquille, Maniflore, parecia inspirada em Séverine ${ }^{244}$, jornalista que toma partido pró-Dreyfus e se liga a Zola "avec tout l'excès de son tempérament" (Bancquart, 1994, p. 1245). De qualquer maneira, a decepção final do personagem aproxima-o de Anatole France

De forma geral, é possível observar na sátira anatoliana uma redução substancial da importância do herói. Partimos, no início deste trabalho, da concepção de um novo tipo de herói, o herói intelectual, nos romances de France e Barreto e em outros autores contemporâneos a ambos. No percurso que traçamos das obras destes autores, enquanto a trama perdia importância, a centralidade dos heróis ainda sustentava a narrativa, principalmente nos seus comentários acerca dos acontecimentos. Com as sátiras, porém, a caricaturização do outro se transforma em procedimento padrão e o herói intelectual perde seu lugar preponderante. Esta redução do espaço do herói tem, por sua vez, consequências em relação à concepção espaço-temporal da narrativa. Enquanto o espaço se desloca para a Ilha dos Pinguins (ou para o país dos Bruzundangas), o tempo se dobra sobre si mesmo. Imerso na decepção em relação aos acontecimentos do caso Dreyfus e diante do temor da guerra iminente, o autor Anatole France traduz na

${ }^{244}$ Séverine foi uma das jornalistas mais conhecidas do jornal feminista La Fronde, criado em 1897 e dirigido por Marguerite Durand. O jornal reproduziu o texto de Zola com uma nota de Séverine exaltando o ato de coragem moral do escritor. Ver Winock (2009). 
narrativa o seu sentimento de desencanto, de um futuro sem perspectiva. Daí o tempo cíclico da narrativa ${ }^{245}$.

No final da sátira, o personagem de Bidault-Coquille retorna ao seu espaço descolado do real. O forte sentimento de decepção ao final do caso dos fardos de feno, depois da libertação de Pyrot e da expulsão de alguns religiosos, nos parece ser um desabafo do próprio autor. Os antigos defensores de Dreyfus destroem-se entre si e "s'accablèrent réciproquement d'outrages et de calomnies" (IP: 1994, p. 187), enquanto as camadas populares às quais os pyrotins (dreyfusards) pediram auxílio são desprezadas na nova era republicana "soumis au contrôle des grandes compagnies financières" (p. 188). Antigos defensores chegam ao poder defendendo os tribunais militares e reprimindo ações populares. Enquanto isso, Bidault-Coquille "contemplait avec tristesse la ville endormie" desabafando para si mesmo:

"Tu te figurais que les injustices sociales étaient enfilées comme des perles et qu'il suffisait d'en tirer une pour égrener tout le chapelet. Et c'est là une conception très naïve. Tu te flattais d'établir d'un coup la justice en ton pays et dans l'univers [...] Et maintenant que tu as perdu tes illusions, maintenant que tu sais qu'il est dur de redresser les torts et que c'est toujours à recommencer, tu retournes à tes astéroïdes." (IP : 1994, p. 189).

Decepcionado, o personagem de Bidault-Coquille retorna para a sua atividade anterior, como se o tempo do caso Pyrot não tivesse alterado verdadeiramente a ordem injusta da sociedade. Mas é nos anos posteriores ao caso Dreyfus que os textos de intervenção de Anatole France se tornam mais frequentes ${ }^{246}$. No caso da sátira limabarretiana, ao final, a narrativa vai se tornando cada vez mais sintética e mal acabada, com trechos que parecem mais notas do que crônicas. As palavras finais sobre os samoiedas são "Já temos muitas bobagens e são bastante. Fico nisto" (Bru, 1956, p. 45). De fato, a questão temporal nas duas narrativas se enuncia de forma distinta. Enquanto no país das Bruzundanges, o tempo parece cindido, sem perspectiva, no caso dos pinguins e da história sem fim, é o tempo cíclico que determina a estrutura temporal. Vejamos então a concepção do mundo futuro na Ilha dos Pinguins e no congresso pamplanetário de Barreto.

\footnotetext{
${ }^{245}$ Esta concepção temporal, como tratamos anteriormente, já aparecia sugerida nos romances.

${ }^{246} \mathrm{O}$ que é possível notar pela coletânea Vers les temps meilleurs.
} 


\section{O mundo futuro}

A crítica satírica de Anatole France adquire um tom premonitório no último livro da obra, que trata do tempo futuro ou da Histoire sans fin. O mesmo acontece num conto satírico de Lima Barreto, O Congresso Pamplanetário, cuja estrutura cifrada encobre a visão sarcástica do criador de Isaías Caminha. Tanto o conto, como o livro do tempo futuro dos pinguins - criaturas que não são nem mesmo nomeados nesta última parte - expõem semelhante temor e criticam o papel dos Estados Unidos no mundo, na mesma trilha do anticapitalismo como posição ideológica.

A estrutura cifrada do tempo futuro anatoliano já aparece numa das quatro épigrafes do capítulo, desvendada por Bancquart que afirma que "ce cryptogramme se lit en remplaçant chaque lettre par celle qui la précède dans l'alphabet”. Depois de explicar o procedimento, a crítica "traduz" a epígrafe:

“Après s'être soustraite à l'autorité des rois et des empereurs, après
avoir proclamé trois fois sa liberté, la France s'est soumise à des
compagnies financières qui, disposant des richesses du pays, et par le
moyen d'une presse achetée, dirigeant l'opinion publique, exercent
une puissance à laquelle n'atteignirent jamais Louis Quatorze ou
Napoléon" (Bancquart, 1994, p. 1258).

A epígrafe assinada por "un témoin véridique", resume a situação da cidade futurista, que nada mais é que o futuro da própria França. A cidade géante, onde os prédios de quarenta andares e a poluição impediam a vista do céu, encontrava-se subordinada ao interesse dos "trusts", meio no qual se formavam os milionários, "des hommes à la fois énergiques et frêles, capables d'une grande puissance de combinaisons mentales, [...] mais dont la sensibilité subissait des troubles héréditaires ...” (IP, 1994, p. 234). Nessa sociedade desumanizada e ascética, onde a piedade era condenada como fraqueza e os prazeres do espírito estavam esquecidos, os ricos compunham uma pequena minoria e eram cercados pelos seus colaboradores, os trabalhadores do comércio, dos bancos e os operários. Enquanto os trabalhadores enriqueciam com a proximidade dos milionários, os operários permaneciam na pobreza.

Além da configuração social, também a análise do sistema capitalista faz parte da narrativa, particularmente a instabilidade desse sistema econômico: "L'intermittence de la production, inhérente au régime capitaliste" tinha como consequência o desemprego e o estado social estava fundado naquilo que existe de mais forte na natureza humana, "l’orgueil et la cupidité” (p. 237). Nessa cidade egoísta, injusta, poluída, que muito se assemelha a algumas das grandes cidades de hoje, o narrador 
vislumbrava a decadência e a destruição de uma França outrora grande e agora subjugada pelo poder americano; poder este que não é diretamente mencionado nenhuma vez, a não ser pela referência aos trustes. Porém, em nota de Bancquart, ela comenta que o tema fora tratado em vários artigos de France na Revue des revues ${ }^{247}$.

Assim como a cidade dominada pelos trustes é uma referência crítica ao poderio econômico norte-americano, também o planeta Júpiter, no conto de Lima Barreto, representa a voracidade do poderio dos Estados Unidos nesse início do século XX. No caso específico do conto limabarretiano, trata-se de uma alusão à coalizão de oito países $^{248}$ com o fim de reprimir um movimento de camponeses na China, grupo conhecido como Boxers ${ }^{249}$. No conto, os países são planetas e Júpiter propõe a reunião de um Congresso Pamplanetário na Terra com a intenção de "formar um espírito planetário, em contraposição ao espírito estelar" (HS, 2008, p. 56).

Segundo Ravel Paz, em dossiê publicado na revista Cult em comemoração aos 80 anos da morte de Lima Barreto, o espírito estelar correspondia ao "bloco comunista". A interpretação de Paz, porém, é um tanto anacrônica, levando em consideração que se trata de um conto de 1920, quando ainda não se podia falar de um "bloco comunista". O espírito estelar pode ser interpretado como o espírito revolucionário, ligado à experiência da Revolução Russa de 1917. Esse espírito revolucionário também aparece na cidade futura de France que, apesar de dominada pelos milionários, tem como oposição a ação dos anarquistas, representados pelo casal Caroline Meslier e Georges Clair, sendo este último o organizador dos atentados que destroem a cidade.

Nada mais interessante nesse último livro da história dos pinguins do que o cataclisma que destrói a cidade, "une détonation retentit jusqu'à eux (Caroline e Georges), tandis que montait vers le ciel pur un immense arbre de fumée” (IP, 1994, p. 241). As explosões e atentados se sucedem por quarenta e um dias até que "Il devenait impossible de déblayer les décombres et d'ensevelir les morts” (p. 246). A descrição das explosões se assemelha ao que conheceríamos depois da bomba atômica, “... un arbre

247 O tema era de fato recorrente no período de formação desses grandes conglomerados comerciais. Em Au Bonheur des Dames, romance de 1883, de Émile Zola, já aparecia retratada a destruição do pequeno comércio local pelos grands magasins. Em nota, Bancquart informa que o primeiro truste americano, Standard Oil, foi fundado em 1881 e em 1904 haviam 318 conglomerados que cobriam quase todo o comércio e a indústria.

${ }^{248}$ Estados Unidos, Áustria-Hungria, Alemanha, França, Itália, Japão, Rússia e Inglaterra.

249 Trata-se de forma geral de um movimento popular chinês anti-reformista e contrário à presença estrangeira no país, cujos membros foram acusados de matar dois missionários alemães em 1897. 
monstrueux, un fantôme de palmier haut de trois kilomètres s'éleva sur l'emplacement du palais géant des télégraphes, tout à coup anéanti” (IP, 1994, p. 245). Premonitório ou imaginativo, o fato é que a conversação entre Clair e Meslier trata das novas descobertas da química, e ele se refere à transformação do rádio em hélio. Bancquart esclarece em nota que Gustave Le Bon, em L'Évolution des forces, de 1907, explicava que "certains corps sont spontanément dissociables et émettent une grande énergie" (Bancquart, 1994, p.1261). Muito provavelmente, segundo a crítica, essa é a origem da imaginação anatoliana. Ainda assim, é impossível ao leitor de hoje não associar a imagem dessa árvore monstruosa à bomba atômica.

Quanto à caracterização dos personagens, como os insensíveis capitalistas do mundo futuro anatoliano, em Júpiter, os habitantes são "rígidos, duros e frios; e têm dous sentimentos dominadores: o do enorme, que é o seu critério de beleza, e do dourado" (HS, 2008, p. 58). Diante dessa potência, cujo desejo escondido era vender seus produtos para os outros planetas ou impor seu modo de vida nas grandes cidades, de um lado, o narrador anatoliano opõe a resistência anarquista, de outro, Lima Barreto descreve um cenário no qual o espírito planetário de Júpiter domina todos os países: "A Terra banalizou-se; Marte perdeu a inteligência; Vênus, o amor desinteressado ...” (p. 61). Porém, do Céu, "Sírius nunca mais cessou de sorrir", representando a esperança no espírito estelar ${ }^{250}$. Apesar de apontar para uma transformação, a oposição dos anarquistas não leva a uma nova situação, já que o tempo cíclico retoma a história da mesma maneira, desde os primórdios. No caso do espírito estelar do conto limabarretiano, o sorriso de Sírius, um semi-anagrama da Rússia, deixa uma fagulha de esperança ao final.

O que une essas duas sociedades imaginárias, futuristas e satíricas, a despeito de algumas diferenças? Em primeiro lugar, o antiamericanismo ou anticapitalismo, e, em segundo, uma clara simpatia pelos movimentos revolucionários. Diante das transformações trazidas pelo progresso tecnológico e concretizadas, principalmente, na desfiguração da antiga Paris e do antigo Rio de Janeiro, os dois narradores expressam o temor diante do rumo dos acontecimentos. No caso de France, o peso da guerra também é sentido, o que confere à narrativa dos pinguins o tom belicoso que inexiste no conto limabarretiano. Ainda assim, é interessante o fato de, apesar de não progressistas,

\footnotetext{
${ }^{250}$ O romance posterior de France, La Révolte des Anges, publicado em 1914, situa no céu a luta de classes.
} 
nenhum dos dois se liga a grupos conservadores; ao contrário, ambos apoiam os movimentos de esquerda, socialistas e anarquistas. Este apoio dos autores, porém, não se traduz na narrativa das sátiras, num tempo futuro esperançoso. Pelo contrário, os anarquistas destroem a megalópole pinguim e no congresso pamplanetário, o espírito estelar permanece somente como possibilidade de transformação, nunca realizada. Em suma, em nenhum dos casos, há uma modificação social efetiva na narrativa. Depois da destruição da cidade gigante, a história dos pinguins recomeça num ciclo infinito. $\mathrm{E}$ Sirius, no seu sorriso, não altera a injustiça social no mundo, restando apenas como uma esperança distante, no céu.

Excluindo o momento de otimismo do senhor Bergeret, o ceticismo anatoliano reduz a um nível muito baixo o processo transformador de seus personagens centrais. A estabilidade psicológica na constância de Coignard, Bonnard e mesmo de Bergeret pode ser associada a essa compreensão temporal cíclica da narrativa anatoliana, explicitada na sátira. O método satírico que, como sugere Lukács, retira o teto das casas para mostrar a realidade, nos permite visualizar com mais clareza aquilo que já aparecia sugerido nos romances. No caso de Lima Barreto, a despeito da pouca transformação de Isaías e Augusto Machado, há um percurso traçado pelo narrador, porém não realizado em função do "cipoal intrincado" da sociedade, ou melhor, do preconceito racial que perpassa e limita a trajetória desses personagens ${ }^{251}$. Esse elemento que impede a transformação dos heróis limabarretianos não apaga o ímpeto inicial dos personagens, mas sim a sua plena realização. Já os personagens sábios do rol anatoliano terminam a narrativa como a iniciaram, observando criticamente a realidade de um lugar protegido. A crítica a Talpa, na narrativa dos pinguins, nesse sentido, pode ser lida também como uma autocrítica aos heróis anatolianos. O teto de sua própria morada se desvela e o que vemos é o intelectual destacado da sociedade, como Bidault-Coquille em seu desapontamento.

Essa compreensão temporal explicitada na sátira também explica uma segunda diferença fundamental, mas extremamente difícil de ser enunciada. Trata-se de uma sensação advinda da leitura das obras desses dois autores. Enquanto na leitura de

${ }^{251}$ No conto pamplanetário, os negros são representados pelos gatos, que não são tolerados pelos jupiterianos, que "se reúnem na praça pública e matam a paulada [...] sob o pretexto de que o 'gato' queria casa ou namorava uma filha deles. Lá se chama banditismo e é cousa parecida com o linchamento yankee" (HS, 2008, p. 59). Ao final do conto, ironicamente, depois do domínio de Júpiter, os gatos passam a "gozar" dos benefícios das instituições do planeta Júpiter, "isto é, foram expulsos da comunhão dos patrícios" (p. 61). 
France, há uma certa artificialidade estilística, no caso de Lima Barreto, há uma naturalidade na composição que se concretiza na própria linguagem. Um dos primeiros indícios mais palpáveis dessa oposição artificialidade versus naturalidade pode ser visto na estrutura das frases e parágrafos. A escrita de Lima Barreto parece acompanhar o fluxo do pensamento do narrador, como na descrição do passeio com Gonzaga de Sá:

"O que me maravilhava em Gonzaga de Sá era o abuso que fazia da faculdade de locomoção. Encontrava-o em tôda parte, e nas horas mais adiantadas. Uma vez, ia eu de trem, vi-o pelas tristes ruas que marginam o início da Central; [...] Segui-o uma vez. Gonzaga de Sá andava metros, parava em frente a um sobrado, olhava, olhava e continuava. Subia morros, descia ladeiras, devagar sempre, e fumando voluptuosamente, com as mãos atrás das costas, agarrando a bengala." (GS, 1956, p. 63).

É quase cinematográfica a descrição de Augusto Machado, trilhando o olhar do leitor pelo percurso de Gonzaga. As frases são curtas, diretas, com poucos ornamentos, salvo o termo "voluptuosamente" e as "tristes ruas". Para tratar desta escrita limabarretiana, talvez seja mais interessante buscar nos trechos mais satíricos, nas caricaturas, nas ironias ou na incorporação de termos cotidianos e orais. O jogo de palavras, "Crisólito - Crisoberilo - Crisópraso" (PS, 2006, p. 1261) e o estudo do dicionário, "Consultar a toda a hora o dicionário" (p. 1290) aparecem com certa frequência nas anotações do autor, assim como algumas máximas do tipo "Se toda a humanidade desse passeios ao Leme, teria mais felicidade" (p. 1245). A linguagem em Barreto, ainda que de forma caótica e não metódica, está associada à conversão da erudição em farsa como forma de protesto. Este teor de denúncia confere à narrativa satírica limabarretiana não somente um aspecto de manifesto contra o seu mundo presente, mas, ao deixar latente a sombra do preconceito social e racial, confere à escrita de Lima Barreto, um elemento transformador que antecipa correntes vindouras. É a própria linguagem que pulsa na sua escrita satírica.

Ainda que haja também uma conversão da erudição em farsa na sátira anatoliana, a escrita não incorpora elementos vivos da língua, mantendo mais uma filiação ao tipo de escrita intelectualizada na linha de Voltaire. De um lado, France usa na sátira uma linguagem de inspiração rabelaisiana, porém, não incorpora nessa linguagem o uso corrente e vivo da língua. A incorporação do passado e do presente em Lima Barreto é como o tijolo da construção, sendo que o cimento que os encaixa é a linguagem corrente e atual, projetando para o futuro. Na mistura da construção literária de Anatole France, o tijolo se estrutura no passado e no presente, mas o cimento que 
une a estrutura não lhe permite elaborar novas formas, pois a linguagem também está marcada pelo tempo passado. A filiação de Barreto a France se dá, portanto, no caminho de transformação da farsa em manifesto, porém, a linguagem desse manifesto se projeta para o futuro no primeiro, enquanto para o último, mantém-se atrelada a um estilo cultivado e distanciado. Nesse sentido, o humanismo satírico estrutura a narrativa como ponto de partida ou concepção do mundo, porém a forma de composição trilha caminhos distintos.

\section{O humanismo satírico}

$\mathrm{Na}$ chave da antiga dicotomia forma e conteúdo literários, poderíamos dizer que a semelhança entre as criações de Lima Barreto e Anatole France é de conteúdo, enquanto a forma difere. A escolha da sátira como objeto final desse estudo comparativo tem como fundamento exatamente a ênfase de conteúdo no método satírico lukácsiano - ressaltando assim a afinidade ideológica entre os autores. Isto porque a forma satírica seria pouco maleável, segundo Lukács. Ele compara L’Ingénu, de Voltaire, de 1767, e A Connecticut Yankee in King Arthur's Court, de Mark Twain, de 1889:

"Estas duas obras partem de uma ideia semelhante do ponto de vista formal, ideia que, de resto, a sátira usa muito frequentemente: transportando um ser humano para um ambiente muito diverso daquele em que vive, seja do ponto de vista histórico, geográfico ou social através dos efeitos de contraste satírico que nascem do contato imedidato entre dois universos que normalmente não têm entre si relações imediatas. Mas o fato é que, enquanto Voltaire desfecha duros e precisos golpes numa série de importantíssimos problemas sociais de sua época, Mark Twain se mantém sempre na superfície ...” (Lukács, 2011, p. 175).

O elemento formal já aparece como um dado no método satírico, segundo Lukács, em função principalmente de uma constância nas principais características desse tipo de escrita: o exotismo da situação, do ponto de vista geográfico, histórico ou social, e o contraste satírico entre o ficcional e o real, que aparentemente não tem relações entre si. $\mathrm{O}$ efeito da ênfase na contradição é exatamente explicitar a crítica à realidade. Já quanto à distância temporal ou geográfica, ao afastar a situação explorada do contexto verdadeiramente retratado, há um efeito oposto de aproximação e crítica. Trata-se, como vimos nas sátiras aqui analisadas, de uma arte combativa, eventualmente panfletária e que conta basicamente com o poder da palavra como arma de luta. As 
contradições do real, explicitadas pelo distanciamento narrativo, reforçam a relação com o mais próximo, revelando o absurdo do real.

O deslocamento da ironia do nível textual para o confronto pelo leitor das perspectivas do narrador e do autor é, do ponto de vista da recepção, uma das explicitações de conteúdo que se processa, no quadro das obras, dos romances para as sátiras. Tal como o narrador, também o leitor deve se posicionar de forma distanciada em relação à obra para reconhecer nela o desatino do real. Nesse deslocamento da ironia, há ainda a presença da interpretação autoral em relação aos debates da época, inserindo mais um elemento na recepção da obra, os elementos históricos e sociais contemporâneos aos escritores e suas formas particulares de intervenção nos assuntos correntes.

No deslocamento do texto para o nível paratextual, os prefácios que problematizaram o gênero romance anteriormente, aparecem nas sátiras como parte da farsa, moralizando a narrativa. Equilibrando o tom combativo - que pode ser resultado do pacifismo dos narradores - temos o aspecto lúdico e jocoso das narrativas, beirando uma brincadeira infantil. Ainda na mesma chave de forma e conteúdo, sugerimos também que a troça - marcada pelas histórias exemplares - seria mais narrativa, enquanto a crítica tenderia a portar uma tendência mais autoral, num jogo entre o anedotário e o digressivo. Esse procedimento já aparece nas crônicas e romances dos dois autores, na mescla entre as histórias e os comentários, assim como está presente nos romances de Gonzaga de Sá e Bergeret.

Porém, é somente no caso de Lima Barreto, que é possível falar de uma criação do novo, à sombra do elemento racial, incorporando na narrativa a linguagem coloquial. Essa diferenciação pode ser explicada por um elemento que foge à alçada das semelhanças entre France e Barreto e toca na questão do exercício da arte como experiência. Clara Ávila Ornellas (2001), no estudo comparativo que faz entre Lima Barreto e João Antônio, e particularmente no que diz respeito ao tolstoísmo de ambos, observa que no caso desses dois autores os elementos biográficos agem como "elo pertinente entre realidade e criação artística" (Ornellas, 2001, p. 215).

No estudo do tolstoísmo, a autora apresenta os principais argumentos da teoria de Tolstói em sua última fase, quando renega sua produção literária anterior, justificando que seus textos doutrinários seriam aqueles que proporcionariam as reais contribuições para o progresso da humanidade. No que diz respeito ao humanismo dos 
autores carioca e paulista, Ornellas atribui a sua origem ao tolstoísmo. Como buscamos argumentar nesse estudo comparativo entre France e Barreto, boa parte do humanismo limabarretiano tem origem na matriz anatoliana, principalmente se considerarmos o viés cristão do tolstoísmo que esbarra, de um lando, no anticlericalismo de France e, de outro, no anarquismo libertário de Lima Barreto. Elementos chaves como a opção definitiva pela literatura - descartada por Tolstói, mas enaltecida por Barreto -, assim como a sua independência ideológica, parecem-nos muito mais ligados à matriz anatoliana. Ornellas não deixa escapar a diferença do ponto de vista cristão entre Tolstói e Barreto, mas compreende a matriz do humanismo de Barreto, como o de João Antônio, a partir do tolstoísmo.

A questão reside em pensar nos caso de todas essas escritas de fins do século XIX e início do XX, nas soluções desencantadas de autores que, ao lidar com a realidade de seus respectivos países constatam a disparidade entre os sonhos de transformação e a realidade circundante. De um lado, os verdadeiros seguidores do tolstoísmo deveriam recusar a atividade literária como forma de transformação, enfatizando os textos mais doutrinários ${ }^{252}$. Porém, no caso de Lima Barreto e Anatole France, a insistência na atividade literária chega às vias de manifesto pela exploração do método satírico, uma solução temporária para a insuficiência do romance como gênero combativo.

A insistência na atividade literária, a despeito do desencanto dos autores, parece unir essas duas literaturas da desilusão. Além disso, uma das críticas de Tolstói em $O$ que é Arte? está no processo de profissionalização da atividade literária que, para ele é uma das causas da perda da sinceridade na arte. Para Tolstói, "la sincérité se trouva affaiblie avec la professionnalisation de l'art" (Tolstoi, 1918, p. 146). Ainda que Barreto tenha tido muitas dificuldades em se manter financeiramente com a atividade literária, $\mathrm{o}$ trabalho na imprensa garantiu o seu sustento, assim como parte das suas obras ao final da vida. Sem um início de profissionalização, a atividade de Barreto, pobre e mulato de origem, seria certamente inviável. O mesmo é possível dizer do filho de livreiro Anatole France.

Porém, alguns aspectos estão, de fato, mais próximos da matriz de Tolstói, como a apreensão da linguagem popular na literatura limabarretiana e o exercício da arte vista literário. 
como experiência. No caso de France, a tendência erudita e digressiva muitas vezes desequilibra a narrativa tornando enfadonha a leitura, assim como reduz a escrita literária a uma atividade de sábio que comenta a vida sem se deixar contaminar pela experiência. Enquanto a escrita distanciada de France restringe a sua leitura nos dias de hoje, no caso de Barreto, o trabalho com a linguagem estimula o desvendamento pelo leitor e a atualização constante da obra. Isso se dá, em grande medida, porque é à linguagem compartilhada entre os literatos de sua época que Barreto se contrapõe, buscando no uso dos termos coloquiais as armas de combate. Seu combate é contra as injustiças, mas também contra um tipo de linguagem que reconstrói a realidade, distanciando-se da mesma. Nesse sentido, a filiação a Anatole France não deixa de ser uma provocação do escritor Lima Barreto, na medida em que desfigura (e reconfigura) a influência desse autor celebrado no Brasil do início do século XX ao defini-lo como um escritor militante.

Essa aproximação existencial com os mais desfavorecidos contribui para inovação limabarretiana, diferentemente do viés erudito anatoliano. É ao humanismo tolstoísta, portanto, que a inovação na escrita de Lima Barreto nos parece mais próxima, ou mesmo a alguma escrita nacional. Ainda assim, é muito mais imbricado o jogo de influências no caso do tolstoísmo. Já comentamos anteriormente a influência que os escritos do russo Léon Tolstói acerca da arte tiveram no meio literário brasileiro, em obras que vislumbravam um mundo melhor e mais igualitário. Porém, não tratamos da posição de France diante do criador de Ana Karénina. Desde o começo do século XX, France elogia o engajamento social de Tolstói, este filho da nobreza russa que se engaja em prol dos camponeses pobres. Em 1908, num texto de celebração dos oitenta anos do escritor russo, France descreve-o como um "demi-dieu nouveau des champs et des bois" e como o "gran Pan évangelique et patriarcal d'Iasnaïa-Poliana" (VTM2, 1953, p. 246). France celebra o homem engajado antes mesmo do escritor.

Os acontecimentos na Rússia já chamavam a atenção na França desde os primeiros anos do século XX. Em 1905, depois da perda da guerra russo-japonesa, explode um movimento de greve no país, cuja origem está na demissão de quatro trabalhadores de uma fábrica de armas em São Petersburgo. O padre Georges Gapone, diretor da "Assemblée des ouvriers russes des fabriques et des usines de Saint- 
Pétersbourg" ${ }^{253}$, escreve ao tsar pedindo a reincorporação dos quatro trabalhadores e uma multidão marcha em direção ao Palácio de Inverno, sendo recebida a tiros pelas tropas do governo. Alguns meses depois, descobria-se que Gapone trabalhava para a polícia de Estado e levara a multidão para a emboscada. O resultado fora de duas ou três mil vítimas, entre elas, mulheres, crianças e velhos. Anatole France é um dos primeiros a assinar uma subscrição em prol das famílias das vítimas do massacre na Rússia, tendo sido também presidente da "Société des Amis du Peuple russe et des Peuples annexés". France também dá palestras sobre esses acontecimentos nas universidades populares, que manifestam seu apoio ao movimento contra a truculência do governo tsarista. Apesar de elogiar o grande escritor russo, France está muito mais ligado à posição engajada de Tolstói nesses textos do que aos seus escritos sobre a arte.

No caso de Barreto, Tolstói é a principal referência de sua concepção de arte no texto escrito para a palestra em Mirassol. Ele segue ordem similar ao texto $O$ que é Arte?, que parte do exame da beleza estética para propor uma teoria sobre a arte enfatizando o papel dessa atividade no progresso da humanidade. Segundo Tolstói, a arte é "un moyen d'union parmi les hommes, les rassemblant dans un même sentiment, et, par là, indispensable pour la vie de l'humanité, et pour son progrès dans la voie du bonheur” (Tolstói, 1918, p. 59). Também Barreto parte da concepção de Tolstói para se perguntar acerca do que é a Beleza e concluir que a arte literária se apresenta "com um verdadeiro poder de contágio" e com a capacidade de ligar os homens entre si, "como semelhantes no sofrimento da imensa dor de serem humanos" (IL, 1956, p. 62). Para Barreto, a missão quase divina da literatura é, certamente, menos religiosa que a arte cristã de Tolstói, que se opõe historicamente a um momento de profissionalização das artes e de constituição da crítica literária. Ainda assim, Barreto segue, como o criador de Ana Karénina, uma direção de projeção futura, "no futuro é que está a existência dos verdadeiros homens" (p. 68), ainda que este futuro nunca se concretize na sua literatura, como vimos em relação ao longínquo espírito estelar.

$\mathrm{Na}$ homenagem que presta pela celebração dos oitenta anos de Tolstói, France ressalta o humanismo do "romancier épique", assim como situa o escritor russo entre os mestres da literatura mundial. A concepção de arte de Tolstói, porém, nem sempre foi bem vista por France. Em 1892, sobre um livro de Wyzewa, prefaciador de $O$ que é

\footnotetext{
${ }^{253}$ Essas informações foram descritas pelo organizador da coletânea de textos de France, Vers les temps meilleurs, Claude Aveline.
} 
Arte?, France afirmara que a doutrina de Wyzewa, assim como a de Tolstói, "ne met son salut que dans l'abêtissement" (VTM3, 1963, p. 141). Apesar do enaltecimento do escritor humanista, a ressalva permanece na homenagem prestada em 1911, um ano após a morte de Tostói:

"Tolstoï, plus haut que ton évangile, plus haut que ton discours dans la plaine de neige, lors de la transfiguration, plus haut que tes béatitudes et que tes paraboles, parlent ton génie épique et ta vie généreuse, et ton coeur vaste et divers. [...] Qu'ai-je parlé de tes erreurs! Tu ne nous as jamais trompés, tu ne t'es jamais trompé, tu as toujours dit la vérité puisque tu as exprimé la beauté, et que la beauté est la seule vérité que l'homme puisse atteindre [...] Non! Tolstoï ne condamne pas l'art. Quoi qu'il ait pu penser et dire, loin de le condamner, il l'exalte et le glorifie!” (VTM3, 1963, p. 143).

A figura de Tolstói aparece acima do teórico da arte e da religiosidade do escritor russo. Além disso, France exalta a beauté como a única verdade a alcançar, categoria estética abertamente renegada por Tolstói. O tom de homenagem encobre as divergências entre os dois autores, o anticlerical, sensualista e engajado France e o salvacionista Tolstói. Inclusive, ao final da homenagem, o foco recai sobre a paz mundial, preocupação de France presente na sátira dos pinguins, com a seguinte frase: "Efforçons-nous tous de travailler, selon nos faibles forces, à l'avènement de ces temps meilleurs, dont le grand Tolstoï eut le vague et sublime pressentiment" (p. 145). O "tolstoísmo" anatoliano - se é que se pode falar de influência - resume-se, portanto, a uma filiação ideológica simpática à visão do escritor russo em relação aos menos favorecidos. Porém, no que diz respeito à concepção de arte de Tolstói, do escritor casto e religioso, ela não poderia estar mais distante do cético e sensualista France, ainda que tempos melhores fossem desejados também pelo escritor francês.

No caso de Lima Barreto, é à teoria de arte de Tolstói que o criador de Isaías Caminha se refere no texto de Mirassol. E, principalmente, é sobre o conceito de Beleza que Barreto se interroga. O primeiro "autor claro" que Barreto examina é Taine: "A Beleza, para Taine, é a manifestação, por meio dos elementos artísticos e literários, do caráter essencial de uma idéia mais completamente do que ela se acha expressa nos fatos reais" (IL, 1956, p. 58). Seguindo a lógica de oposição aos "helenizantes de última hora", Barreto atribui valor à substância da obra, o essencial nos termos da teoria de Tolstói que se opõe, por sua vez, à arte cujo único fim é o prazer, fruto da perda da fé 
das classes altas. Ainda que a filiação ao tolstoísmo em Barreto seja pouco precisa ${ }^{254}$, ela é bem presente na comunicação dos sentimentos, no poder de contágio da obra de arte, na missão divina, na projeção futura, além do aspecto moral da compreensão da beleza. Barreto, como Tolstói, condena a arte que serve somente ao prazer, sendo que esse fim hedonista é como "imitar os homens de uma moralidade primitiva, como os selvagens" (IL, 1956, p. 65). O sensualista France não poderia ter concordado com essa condenação do prazer, ainda que tenha se engajado contra as injustiças sociais de sua época.

O salvacionismo na concepção limabarretiana foi visto por Prado como um dos limites formais na obra de Lima Barreto. O crítico dos bovarismos teria provado de seu próprio veneno fazendo coincidir realidade e fantasia "enquanto polos do antifracasso" (Prado, 1979, p. 105). Na construção do seu utopismo, que segue na teoria a linha do tolstoísmo, Barreto teria caído na emboscada do bovarismo que tanto criticara. Ainda que as limitações do ponto de vista ideológico apontem de fato nessa direção, o exame da construção do modelo estórias exemplares-digressões de alguns trechos de sua sátira apontam para outra direção, de uma riqueza ainda inexplorada da obra de Barreto. Nesse sentido, o estudo comparativo com France pôde iluminar, também no espaço da diferença, a projeção da literatura militante limabarretiana: essa busca de uma forma particular de escrita na literatura brasileira que, no cotejamento diário com as crônicas publicadas nos jornais e na elucidação da intenção por trás do escárnio, antecipam a empreitada modernista.

\section{Modelo estória exemplar-digressões}

No capítulo XXI de Bruzundangas, intitulado Pancome, as suas ideias e o Amanuense ${ }^{255}$, encontramos um exemplo do tipo de composição de Lima Barreto que

${ }^{254}$ A teoria de arte de Tolstói é muito mais ampla e detalhada, partindo de várias concepções de beleza para construir a sua própria ideia de beleza ligada mais à bonté, bondade, do que a um conceito estético abstrato. Além disso, as críticas a escritores como Baudelaire e Verlaine, ou ao movimento simbolista na pintura, fazem de sua teoria um alvo de controvérsias, sem mencionar a filiação cristã de sua concepção de arte.

${ }^{255}$ Em pesquisa realizada na Biblioteca Nacional do Rio de Janeiro em janeiro de 2013, o conteúdo dessa crônica aparece na Gazeta da Tarde do dia 21 de agosto de 1911 sob o título "A nomeação justa". Não foi realizado para esse trabalho um cotejamento mais preciso das modificações do texto publicado no jornal com a versão em livro, muito em função da indisponibilidade para consulta do periódico A.B.C. de 1917, ano em que foi publicada a maior parte dos textos sobre as Bruzundangas. O início do texto de 1911 da Gazeta da Tarde difere um pouco da versão do livro, assim como o título, porém a história é a mesma. Além disso, ao final da crônica no jornal consta a origem do texto, "Das Notas sobre o Império da Bruzundanga". A contribuição de Lima Barreto para a Gazeta da Tarde é bastante irregular no ano pesquisado, mesmo considerando que parte do material não pode ser consultado 
integra o modelo estórias exemplares-digressões anatoliano com lampejos da compreensão de arte de Tolstói. A filiação a Anatole France aparece aí combinada com a projeção para o futuro do tolstoísmo. O visconde de Pancome representa o barão do Rio Branco, também chamado Sr. Paranhos ${ }^{256}$ na crônica A corte do Itamarati, publicada em novembro de 1918 no A.B.C. No capítulo de Os Bruzundangas, a questão em discussão é a nomeação de um amanuense para o ministério do Exterior, o que ensejou uma revisão de tudo o que já tinha sido referido a Pancome anteriormente. No capítulo sobre a diplomacia da Bruzundanga, Pancome é descrito como "um embaixador gordo e autoritário, megalômano e inteligênte" (Bru, 1956, p. 80) e em Os heróis, o satirista ressalta o desconhecimento deste das "ânsias, as dificuldades, as qualidades e defeitos de seu povo" (p. 106). Esse homem gordo e pouco ligado às coisas do povo, fazia "do seu ministério coisa própria e sua", o que não auxiliava em nada "a marcha de sua pátria" (p. 143/144). De um lado, Barreto retoma a descrição da corte do Itamaraty na crônica, que era denominado pelo povo de "palácio do menino de ouro", de outro, reforça que o grande mal do homem público seria a sua não preocupação com o cidadão "para encaminhar melhor a evolução do país".

O aspecto inovador da sátira limabarretiana está nessa fusão entre a fala do povo e uma concepção humanista e transformadora da sociedade, a despeito da desilusão pessoal do autor. A melhor realização desse narrador é quando existe uma concisão dos elementos presentes na obra como um todo, como Prado (2008) sugeriu acerca da síntese presente na coletânea Histórias e Sonhos. Nesse capítulo sobre o barão do Rio Branco se encontra a crítica aos jornalistas e jornais "habituados a canonizações simoníacas" (Bru, 1956, p. 145) que caracterizou a narrativa de Isaías Caminha, juntamente com os vates bajuladores e os tolos de todo o tipo que reverenciam Pancome. A figura de Rio Branco é central também em Gonzaga de Sá, sem deixar de mencionar o contraste que remete também à situação de Policarpo Quaresma:

“... nos arredores da capital, se morria à míngua, à forme, as terras estavam abandonadas e invadidas pela depredadoras saúvas, a população roceira não tinha direitos nem justiça e vivia à mercê de cúpidos e ferozes senhores de latifúndios ...” (Bru, 1956, p. 149-150).

Mas a denúncia mais ácida não aparece sem o acompanhamento da leveza irônica das estórias exemplares, como é o caso da entrevista com o belo candidato que

em função da falta de condições de manuseio do papel jornal. Em 1911, foram publicadas crônicas assinadas por Lima Barreto em 20 de abril, 10 de julho, 21 de julho, 21 de agosto e 20 de outubro.

${ }^{256}$ Não há disfarce no Paranhos, já que o nome do barão é José Maria da Silva Paranhos Júnior. 
Pancome busca a todo custo para preencher uma vaga no ministério. As "habilidades" requisitadas pelo ministro são o sorriso, o cumprimento de mão, a dança e, por fim, uma carta. Somente na última tarefa o candidato se revela incapaz, mas mesmo assim, acaba contratado $^{257}$.

Não estaria essa denúncia do belo na mesma chave da concepção crítica da literatura e da própria linguagem hegemônica entre os literatos brasileiros? Não seria esse belo também um contraponto à suposta feiura que Pancome vê nos negros e mulatos? Não seria ainda a presença escondida de javaneses e mestiços nas Bruzundangas, a denúncia do real ocultada pela falsidade do "bruzundanguense conhecido na Europa" (Bru, 1956, p. 147)?

É na sátira limabarretiana, mais do que em outros momentos da obra, que o modelo estórias exemplares-digressões ganha uma projeção ideológica que quando bem realizada, como é o caso dos Samoiedas ou de Pancome, nos revela a presença de um escritor que soube, como poucos na história da literatura brasileira, integrar influências e amalgamar questões que se encontram presentes em diversos momentos da sua obra, apresentando ao leitor uma visão de mundo e uma inovação formal. No que diz respeito ao seu humanismo, mostramos a filiação à matriz anatoliana e sugerimos a incorporação do tolstoísmo nas inovações formais de introdução da linguagem popular na narrativa e de uma incipiente antropofagia na narrativa. É possível dizer que o tolstoísmo limabarretiano está presente na sua concepção de arte, enquanto o seu anatolismo fundamenta a sua compreensão de mundo.

A presença de Anatole France na obra limabarretiana foi apresentada aqui desde a (re)configuração do ambiente literário, passando pelos paratextos, pelo herói intelectual, pelas comparações textuais e pelas transposições de situações sociais e política, chegando às sátiras como forma de explicitação desses elementos contidos em menor grau nos romances, contos e crônicas, ou pelo esgotamento do gênero romance como forma de protesto, transformado pelo humanismo satírico em farsa e manifesto. Esse humanismo satírico de France e Barreto está presente em cada um dos procedimentos examinados, mas mais do que isso, está latente numa compreensão do poder da palavra como agente transformador da realidade. Ainda que nenhum deles

257 Esse diálogo reaparece resumido um pouco mais à frente no capítulo No Gabinete do Ministro, o que sugere que a obra, apesar de ter sido montada pelo autor, apresenta-se em esboço em várias partes. Esse capítulo mesmo não possui numeração, fazendo parte das Notas Sôltas, capítulo XXII, o último da sátira. 
tenha tido o êxito desejado, é nesse espaço de não realização que deixaram marcada uma atitude de independência crítica e lucidez intelectual transmitida por contágio ou qualquer outra marca de relação compartilhada, a despeito da distância física e da defasagem temporal.

Um último elemento que merece uma referência na constituição do humanismo satírico é a dissolução do herói intelectual que, no movimento de caricaturização do outro, acabou ele mesmo por perder sua humanidade. A farsa que se converte em manifesto não comporta mais um personagem com a visão do todo. Nem mais o narrador nos oferece essa visão, mas sim fragmentos do real só revelados na resolução do enigma satírico. A fragmentação do herói, estudada e criticada no romance realista por Lukács, é agora dissolução, mas o narrador toma as rédeas da obra, comentando e interpretando a realidade transposta. A complexidade do real reduziu os personagens a tipos que representam um "sistema filosófico" particular. O jogo do satirista é encobrir nos tipos os personagens reais, deixando o desvendamento do todo para o leitor. $\mathrm{O}$ humanismo satírico é, por fim, a forma ideológica de um desencanto que insiste no poder da palavra transformando a literatura em farsa e protesto. 


\section{Conclusões}

A resolução do caso Dreyfus não foi completa. Apesar da reintegração do capitão ao exército em 1906, da sua condecoração como membro da Légion d'Honneur, da nomeação de Georges Clemenceau, um dos mais aguerridos militantes da causa revisionista, como primeiro-ministro, e do general Picquart como seu ministro da Guerra, foram deixadas de lado as irregularidades dos dois processos que condenaram erroneamente o capitão judeu. Esta abertura deixou uma fagulha de esperança entre os grupos nacionalistas e antisemitas, uma situação em aberto que teria consequências na divisão política na França, segundo Michel Winock (2009).

Uma delas diz respeito ao socialismo francês, principalmente com a influência intelectual e moral de Jean Jaurès, recentemente homenageado na posse do presidente François Hollande (2012-). Jaurès soube, segundo Winock, assimilar a causa de Dreyfus à causa socialista: "défendre un innocent persécuté, fût-il un officier, fût-il un bourgeois, c'était viser la finalité universelle du socialisme"(Winock, 2009, p. 187). Boa parte da esquerda rejeitou esta tese de Jaurès. Este "socialismo dos intelectuais",258 se separou, desde então do "socialismo ouvrier", de forte tendência anti-intelecutal e sindicalista.

Winock insiste na preponderância moral de Jaurès e de seus partidários durante todo o processo Dreyfus, assim como na configuração do socialismo intelectual na França, inserido por este grupo no sistema republicano, tornando-se sua força de sustentação. Segundo Winock, cabia ao socialismo terminar o que havia iniciado na Revolução de 1789, porém, esta finalização se deu no seio mesmo da República. Ainda que tenha perdido sua força revolucionária, o socialismo intelectual foi parte de um processo específico francês que envolveu uma participação inaudita dos intelectuais na vida pública do país.

Um fator que contribuiu para a hegemonia desta esquerda intelectualizada foi o apoio de parte da esquerda revolucionária ao movimento boulangista, como foi o caso de Henri Rochefort, diretor do L'Intransigeant. Justiça seja feita, é necessário lembrar

${ }^{258}$ Esta esquerda intelectualizada foi responsável por ações importantes na imprensa, seja na presença maciça na redação de l'Humanité, fundada por Jaurès em 1904, na elaboração das edições da "Bibliothèque socialiste", assim como na organização das universidade populares. 
que esta esquerda logo se separou do grupo dos nacionalistas que, por sua vez, migraram para uma posição cada vez mais xenófoba e antisemita.

Todo este circunlóquio nos pareceu necessário para recompor o lugar de Anatole France no debate público da época e, de alguma maneira, fazer um pouco de justiça ao seu legado, tão negligenciado, principalmente depois da devastadora crítica dos surrealistas. Afinal, mesmo que sua obra não tenha mais o mesmo apelo junto ao público de que o escritor usufruiu em seu tempo, sua posição ideológica independente merece, sem dúvida, alguma deferência. A interpretação corrente de Anatole France no Brasil do início do século XX seguiu a lógica criticada pelos modernistas do sensualista da ironia e piedade, do "bon chic, bon genre", cuja influência só poderia recair, como no mapa de Jeffrey Needel, sobre figuras como Olavo Bilac ou Coelho Neto. Felizmente, a leitura de Lima Barreto da obra anatoliana subverte esta interpretação. Como sempre provocador, o criador de Isaías Caminha viu na obra de Anatole France as bases para a sua literatura militante.

A provocação tem dois lados. Do primeiro, a leitura de Lima Barreto parte de uma busca pelos traços distintivos e essenciais da obra literária. Para o escritor, a literatura é antes de tudo um compromisso. O seu olhar crítico busca nas obras que lê, algo como a essência da escrita, o que está por trás das afirmações do narrador ${ }^{259}$ e do autor. É com este olhar que Lima Barreto se apropria da obra de Anatole France. Vimos como a obra do escritor francês pressupõe uma abertura interpretativa e criativa e como ambos os narradores se utilizam de uma lógica enganadora, percebida no uso de conectivos imprevistos nas frases. Os dois se utilizam de uma "ironia sutil e subversiva que 'doura a pílula' sem deixar de aplicar o remédio". Nesta leitura particular, Lima Barreto dialoga com Anatole France. Foi nesta chave que examinamos as respectivas obras.

De outro lado, a matriz anatoliana também exerce, como vimos na sátira dos Bruzundangas, um papel de legitimação da crítica. Pelo fato de ser conhecido e admirado nos meios culturais brasileiros, a própria alusão a Anatole France não era desprovida de valor. Certamente, Lima Barreto estava ciente do valor cultural do aval anatoliano. Essa talvez seja a interpretação mais imediata da relação, uma apropriação utilitária de Lima Barreto. Porém, conhecendo um pouco a trajetória e a posição deste

259 Um excelente exemplo da leitura crítica de Lima Barreto está em "Anita e Plomark, Aventureiros", texto no qual o escritor observa por trás da história "o mecanismo espiritual" da submissão da meretriz (IL, 1956, pp.133-138). O texto foi originalmente publicado no A.B.C. em 16-2-1918. 
autor, cujo destino trágico comove pela sua injustiça, esta interpretação nos parece equivocada. Há ainda uma outra possibilidade crítica que recai na premissa da pouca precisão conceitual de Lima Barreto. Nesta linha, a obra de Anatole France poderia ter sido equivocadamente interpretada por Lima Barreto. É certo que, na sua apropriação, o criador de Isaías Caminha confere um entendimento particulara à obra. Porém, ele não cria a referência, ele apenas retira do que lê essa essência do escritor e de sua compreensão do mundo.

$\mathrm{Na}$ sua particular interpretação, parece-nos existir uma semelhança entre o processo errático dos narradores limabarretianos e o olhar crítico autoral. A qualidade errática das leituras de Lima Barreto, das mais diversas matizes ideológicas, nos levou a esta suspeita. Assim como Augusto Machado e Gonzaga de Sá circulam na cidade do Rio de Janeiro sem ponto fixo ou meta de chegada $^{260}$, o olhar crítico do leitor Lima Barreto percorre os livros retirando deles ou uma essência ou uma afinidade. No caso de Anatole France, é a visão crítica e o aspecto social da obra que requisitam a atenção limabarretiana, componentes fundamentais da ironia redentora que Nicolau Sevcenko atribuiu aos dois escritores.

A sua genealogia estaria, segundo o historiador, em José Veríssimo, cuja ironia "de cunho social e reforçadora da solidariedade humana" Sevcenko opõe à "ironia amarga e cética de Machado de Assis". Vimos no decorrer do trabalho várias características da ironia em Lima Barreto e Anatole France. Do sentido básico de oposição na ironia verbal, cuja intenção é de convencimento, passando pela valoração crítica e moralista, que visa corrigir um mundo injusto, e pela denúncia social, chegamos à ironia militante das sátiras. No que diz respeito a esta "ironia militante", adicionamos ainda dois elementos: a amargura contida na crítica, que acaba completando o espaço do vazio utópico, e a dissolução do herói intelectual. A ironia não se destina mais somente ao processo de caricaturização do outro ou de uma determinada situação pelo herói intelectual, mas atinge tudo que está ao redor do satirista.

Na pena do satirista, a ironia se transforma em atitude irônica. Sua militância está imbuída da visão de mundo do autor, assim como visa à correção das injustiças a partir de um universo imaginário. Neste percurso da ironia verbal para a atitude irônica, observamos, nas obras de Anatole France e Lima Barreto aqui estudadas, não somente a

260 Não pensamos aqui na figura do flâneur, pois o narrador limabarretiano tem o olhar direcionado para os excluídos da sociedade. 
dissolução do herói intelectual, como também uma visada satírica, uma orientação para o universo satírico. O modo de imaginação satírico introduz, portanto, um novo tipo de ironia que visa a corrigir a realidade deturpada, ao mesmo tempo em que ressalta uma inadequação dos narradores a um gênero que não mais comporta a virulência da crítica, um espelho do desacordo dos autores diante de suas realidades.

Nas sátiras, repete-se, de alguma forma, o discurso direto das crônicas, acrescido, porém, de alguns disfarces. O modelo estória exemplar e digressões, já ensaiado em algumas das crônicas limabarretianas, é retomado nos melhores momentos satíricos, como nos Samoiedas, revelando uma habilidade rara num escritor brasileiro: de integrar influências e amalgamar questões políticas, sociais e culturais na obra, ao mesmo tempo em que apresenta ao leitor uma visão particular de mundo. De forma semelhante, porém, as crônicas e sátiras limabarretianas reivindicam atualização do seu conteúdo pelo leitor, para que o elemento local e restrito ao universo de composição possa se generalizar e cumprir, mesmo fora de contexto, a função corretiva da sátira. A sua leitura, como a leitura de France por Barreto, reivindica a aquiescência do leitor.

$\mathrm{Na}$ introdução deste trabalho, apontamos alguns estudos críticos que já haviam sugerido a aproximação entre Lima Barreto e Anatole France. No caso dos anatolianos de Sérgio Miceli, a comparação se deu no campo das afinidades de trajetórias de autores que, por não se enquadrarem em nenhuma das categorias da época, prefiguravam um "tipo novo de intelectual profissional". Nesta categorização de percurso, talvez seja possível dizer que Lima Barreto foi anatoliano no modelo de Miceli. Porém, a perspectiva de Miceli tem um ponto de chegada, o projeto modernista. Para Miceli, Anatole France representa um modelo intelectual atrasado do qual os anatolianos ficariam sempre dependentes, diferentemente dos modernistas, cuja escolha foi a de "se tornarem os importadores do programa estético, ético e político das vanguardas europeias" (Miceli, 1977, p. 83).

A tradicional inclusão de Lima Barreto como pré-modernista também parte do mesmo pressuposto crítico que traz em si um ponto de chegada. Naquilo que o escritor antecipa do modernismo, a relevância de sua obra foi exaltada. As limitações do seu projeto estão ligadas, como no atraso anatoliano, aos modelos ultrapassados ou ao seu ecletismo teórico. Ora, neste trabalho buscamos atenuar estas duas posições. De um lado, o modelo anatoliano certamente não atende as expectativas do leitor de hoje, mas traz, na sua essência, elementos vivos, tanto do ponto de vista ideológico, na posição 
independente deste autor, como literário, nas marcas da ironia, no tipo de herói ou no jogo livre entre os gêneros literários. De outro, o mal do ecletismo, denunciado por Astrojildo Pereira ${ }^{261}$, não percebe o tipo de leitura errática e criativa que Lima Barreto conseguiu fazer com seu método nada sistemático.

O crítico Agripino Grieco foi bastante enfático em relação a Os Bruzundangas ao dizer que a obra foi arrancada de Lima Barreto por admiradores inconvenientes, "num período em que o talento do ficcionista já se achava de todo esfrangalhado" (apud Prado, 1989, p. 57). Sem dúvida, trata-se de uma obra mal acabada. Porém, nela é possível descobrir elementos que aparecem somente sugeridos na obra limabarretiana, seja nas crônicas, contos ou romances. Do ponto de vista crítico, portanto, é uma obra relevante. Mas não somente. Também do ponto de vista literário, a integração de uma visão de mundo e um modo de imaginação nos parece não somente inusitado como instigante. Foi a partir desta configuração literária provocadora que o exercício da crítica teve aqui seu percurso traçado. A imaginação e as situações que nos são apresentadas tanto em $A$ Ilha dos Pinguins como no país das Bruzundangas foram a porta de entrada da indagação das afinidades entre dois autores tão próximos e tão distantes.

Barreto foi anatoliano na forma de pensar a literatura e o estar no mundo, assim como no projeto satírico de sua obra. Barreto foi também um leitor-modelo da obra anatoliana, mas não um anatoliano nos moldes biográficos de Miceli. Sua trágica existência, na verdade, parece-nos bem distante do escritor reconhecido, a despeito mesmo das posições políticas mais à esquerda de France. Por tudo isso, a relação entre Lima Barreto e Anatole France não deve ser pensada em termos de influências, mas sim de afinidades entre um escritor que reivindica interpretações criativas e um leitor e crítico que se apropria da sua obra. Enquanto pensada sob a dupla perspectiva: Anatole France como o "bon chic, bon genre", o tradicionalista burguês marcado pela crítica surrealista, e Lima Barreto, como um pré-moderno, escritor menor na história literária brasileira, a relação não pode se completar. Talvez, desta perspectiva, eles estejam mesmo dispostos em polos opostos no mundo literário.

Ainda que as principais conclusões deste trabalho tenham já sido apontadas, gostaria, antes de finalizar, de reintroduzir a perspectiva crítica de Antonio Arnoni

\footnotetext{
${ }^{261}$ Ver Prefácio de Bagatelas (1956).
} 
Prado, com a qual vimos trabalhando em relação à obra limabarretiana. Prado inicia seu livro fazendo justiça ao escritor e intelectual Lima Barreto:

Ler os livros de Lima Barreto é de alguma forma participar do drama do intelectual sitiado. Mas talvez mais do que isso, é um exercício de consciência histórica que conta com a vantagem, como poucas vezes noutro escritor brasileiro, de um difícil testemunho: constatar como a vida, e nesta a opressão e o fracasso, se converte em literatura. (Prado, 1989, p. 03)

No início da última parte deste trabalho, duas epígrafes sobre a ironia pareceram desconectadas do objeto satírico. Para Anatole France, a ironia seria "la dernière phase de la désillusion", enquanto para Lima Barreto, "A ironia vem da dor". Prado ressalta no trecho acima o difícil exercício de leitura do escritor brasileiro pela constatação da conversão da opressão e do fracasso em literatura. Este exercício de consciência histórica do crítico foi fundamental para a complexa compreensão que Prado nos oferece da obra limabarretiana, integrando na sua literatura a dolorosa existência de Lima Barreto. A compreensão daquilo que existe de mais profundo na obra anatoliana nos parece ter sido o exercício crítico do criador de Gonzaga de Sá. A desilusão e o desconforto deste intelectual das letras diante de seus contemporâneos, da política e dos desfavorecidos foi captado pela leitura limabarretiana. Pela sua obra, lemos Anatole France de uma outra forma. Neste sentido, o crítico Lima Barreto talvez mereça um pouco mais de atenção, numa possível recuperação pelo olhar limabarretiano de obras esquecidas na nossa história literária.

Prado percorre grande parte da obra de Lima Barreto de um ponto de vista diferenciado. Ele o lê a partir do um projeto de renovação empreendido pelo escritor. Da recusa expressa da máscara do literato, passando pela refutação da linguagem acadêmica, assim como de todo o peso da tradição na literatura brasileira, Lima Barreto lança com sua obra um grande manifesto de resistência e questionamento do fazer literário. Nesta busca pela verdade literária, porém, o trajeto não cumpre necessariamente o projeto, e Prado vê no solidarismo de Lima Barreto a limitação de seus planos. Na tentativa de se ocupar dos debates de sua época, Barreto acaba enredado, segundo Prado, "num nível de solidariedade puramente ético, que para num modelo abstrato da consciência altruística pequeno-burguesa" (p. 81).

Um pouco antes desta observação, Prado faz uma breve referência à presença de Anatole France nas fontes da militância limabarretiana, como indicado pelo próprio escritor brasileiro. Afirma o crítico que, se é nas obras de Anatole France que Barreto 
vai buscar uma "confirmação abalizada", estariam nos ecos esparsos de Taine, Brunetière e Guyau a sustentação de seu esboço de projeto literário, "a conversão do escopo sociológico em programa solidarista" (Prado, 1989, p. 73-74). Já sugerimos anteriormente que as alusões a Anatole France têm um papel de legitimação, ao mesmo tempo que provocativo. Porém, o diálogo que Lima Barreto trava com a matriz abalizada de France vai muito além de uma mera confirmação. No quadro do projeto militante limabarretiano, a perspectiva ideológica do escritor francês, ligado à esquerda intelectualizada, que abdicou dos projetos revolucionários confiantes no poder da palavra, é definitiva. Esta perspectiva, como buscamos mostrar no quadro de diálogos parisienses de Anatole France, difere, certamente, dos ecos esparsos de Taine e Brunetière. O solidarismo anatoliano é também uma posição política, de engajamento pela palavra.

Do ponto de vista literário, o projeto em comum que traçamos aqui buscou dar conta da gradual perda do poder da palavra frente a uma posição política fundada nesta possibilidade. A opção satírica é, neste sentido, uma necessidade, mais do que uma opção. O humanismo satírico é assim uma resposta possível de um projeto político e social que se almeja representar na literatura. Nas suas falhas e limitações, não deixa, porém, de alcançar momentos primorosos nos quais o lirismo digressivo e a ironia das estórias exemplares ganham ares de grande literatura. 


\section{Bibliografia Específica}

\section{Obras de Lima Barreto}

BARRETO, Lima. Triste fim de Policarpo Quaresma. Introdução e notas de Lilia Moritz Schwarcz, Lucia Garcia e Pedro Galdino; prefacio de Oliveira Lima. São Paulo: Penguin Classics Companhia das Letras, 2011.

Recordações do escrivão Isaías Caminha. Introdução de Alfredo Bosi; prefácio de Francisco de Assis Barbosa; notas de Isabel Lustosa. São Paulo: Penguin Classics Companhia das Letras, 2010.

Contos completos de Lima Barreto. Organização e introdução Lilia Moritz Schwarcz. Sao Paulo: Companhia das Letras, 2010.

Diário do hospício; Cemitério dos vivos. Prefacio de Alfredo Bosi, organização e notas de Augusto Massi e Murilo Marcondes de Moura. São Paulo: Cosac Naify, 2010.

Histórias e Sonhos. Edição preparada por Antonio Arnoni Prado. São Paulo: WMF Martins Fontes, 2008.

Prosa Seleta. Rio de Janeiro: Nova Aguilar, 2006.

. Toda Crônica: Lima Barreto. Volume I. Apresentação e notas Beatriz Rezende; organização Rachel Valença. Rio de Janeiro: Agir, 2004.

Toda Crônica: Lima Barreto. Volume II. Apresentação e notas Beatriz

Rezende; organização Rachel Valença. Rio de Janeiro: Agir, 2004.

Aventuras do Dr. Bogóloff. Rio de Janeiro: Expressao e cultura, 2001.

Os Bruzundangas. Porto Alegre: L\&PM, 1998.

O Subterrâneo do Morro do Castelo: um folhetim de Lima Barreto. 
Organização, introdução e notas de Beatriz Resende. Rio de Janeiro: Dantes, 1997.

Vida e Morte de M. J. Gonzaga de Sá. Volume IV. Prefácio de Alceu

Amoroso Lima. São Paulo: Editora Brasiliense, 1956.

. Histórias e sonhos. Volume VI. Prefácio de Lúcia Miguel Pereira. São

Paulo: Editora Brasiliense, 1956.

Impressões de Leitura. Volume XIII. Prefácio de M. Cavalcanti Proença.

São Paulo: Editora Brasiliense, 1956.

. Correspondência Ativa e Passiva - Tomo I. Volume XVI. Prefácio de

Antonio Noronha Santos. São Paulo: Editora Brasiliense, 1956.

Correspondência Ativa e Passiva - Tomo II. Volume XVII. Prefácio de

B. Quadros. São Paulo: Editora Brasiliense, 1956.

Bagatelas. Volume IX. Prefácio de Astrojildo Pereira. São Paulo: Editora

Brasiliense, 1956.

$* * *$

Obras de Anatole France

FRANCE, Anatole. Monsieur Bergeret em Paris. Tradução de Joao Guilherme Linke. Rio de Janeiro: Edições BestBolso, 2010.

O Anel de Ametista. Tradução de Joao Guilherme Linke. Rio de Janeiro:

Edições BestBolso, 2010.

O Manequim de vime. Tradução de Joao Guilherme Linke. Rio de Janeiro:

Edições BestBolso, 2009.

À sombra do Olmo. Tradução de Joao Guilherme Linke. Rio de Janeiro:

Edições BestBolso, 2009.

. Os Deuses têm sede. Tradução por Daniela Jinking e Cristiano Murachco; 
prefácio por Marcelo Coelho. São Paulo: Boitempo, 2007.

. [1909] L'Île des pingouins, in Oeuvres IV. Édition établie, présenté et annotée par Marie-Claire Bancquart. Paris: Gallimard, 1994. Bibiothèque de la Pléiade.

. [1912] Les Dieux ont soif, in Oeuvres IV. Paris: Gallimard, 1994.

[1914] La Révolte des Anges, Oeuvres IV. Paris: Gallimard, 1994.

. [1899] L'Anneau d'Améthyste, in Oeuvres III. Paris: Gallimard, 1994.

. [1901] M. Bergeret à Paris, in Oeuvres III. Paris: Gallimard, 1991.

. [ 1899] Pierre Nozière, in Oeuvres III. Paris: Gallimard, 1991.

[1899] Crainquebille, Putois, Riquet, et plusieurs autres récits profitables,

in Oeuvres III. Paris: Gallimard, 1991.

. [1905] Sur la Pierre Blanche, in Oeuvres III. Paris: Gallimard, 1991.

. [1893] La Rôtisserie de la Reine Pédauque, in Oeuvres II. Paris:

Gallimard, 1987.

[1893] Les Opinions de M. Jérôme Coignard, in Oeuvres II. Paris:

Gallimard, 1987.

. [1894] Le Lys Rouge, in Oeuvres II. Paris: Gallimard, 1987.

. [1897] L'Orme du Mail, in Oeuvres II. Paris: Gallimard, 1987.

[1897] Le Manequin d'Osier, in Oeuvres II. Paris: Gallimard, 1987.

A Ilha dos Pingüins. Tradução de João Guilherme Linke. São Paulo:

Difel, 1986.

. [1881] Le Crime de Sylvestre Bonnard, in Oeuvres I. Paris: Gallimard, 1984.

[1882] Les Désirs de Jean Servien, in Oeuvres I. Paris: Gallimard, 1984.

[1885] Le Livre de mon Ami, in Oeuvres I. Paris: Gallimard, 1984. 
. [1890] Thaïs, in Oeuvres I. Paris: Gallimard, 1984.

[1892]) L'Étui de Nacre, in Oeuvres I. Paris: Gallimard, 1984.

Les Fous dans la Littérature. Édition présentée par Georges Londeix.

Paris: Le Castor Astral, 1993.

Vers les temps meilleurs: trente ans de vie

sociale (1915-1924). Volume IV. Comentés par Claude Aveline et Henriette Psichari. Paris:

Éditions Émile-Paul Frères, 1973.

. Vers les temps meilleurs: trente ans de vie sociale (1909-1914). Volume

III. Comentés par Claude Aveline et Henriette Psichari. Paris: Éditions Émile-Paul Frères, 1963.

Vers les temps meilleurs: trente ans de vie sociale (1905-1908). Volume

II. Commentés par Claude Aveline. Paris: Éditions Émile-Paul Frères, 1953.

Vers les temps meilleurs: trente ans de vie sociale $(1987$ - 1904). Volume

I. Commentés par Claude Aveline. Paris: Éditions Émile-Paul Frères, 1949.

A justiça dos homens. Tradução de Joao Guilherme Linke. Rio de Janeiro:

Civilização Brasileira, 1978.

O crime de Sylvestre Bonnard. Tradução de Álvaro Moreyra; estudo introdutivo de Jacquest Chastenet; ilustração de Claus. Rio de Janeiro: Editora Delta, 1963.

La Vie Littéraire: Première Série. Paris: Calmann-Lévy, 1925.

La Vie Littéraire: Deuxième Série. Paris: Calmann-Lévy, 1925.

[1923] Le jardin d'Épicure. Paris:Calmann-Levy. Disponível em: http://classiques.uqac.ca/classiques/france_anatole/jardin_epicure/a_france_jardin_epicure.pdf Acesso em: 22 maio 2011. 


\section{Outros Romances contemporâneos}

DU GARD, Roger Martin. [1913] Jean Barois. Paris: Gallimard, 2003.

BARRÈS, Maurice. [1897] Les déracinés. Paris: Le Livre de Poche, 1967.

BOURGET, Paul. [1889] Le disciple. Édition établie, préfacée et annotée par Antoine Compagnon. Paris: Le Livre de Poche, 2010.

BLOY, Léon. [1887] Le désesperé. Présentation, notes, documents, chronologie et bibliographie para Pierre Claudes. Paris: GF Flammarion, 2010.

NETO, Coelho. [1897] A Conquista. Porto: Lello \& Irmão editores, 1913.

[1898]. O Morto: memórias de um fuzilado. Prefácio de José Maurício

Gomes de Almeida. Rio de Janeiro: Fundação Biblioteca Nacional, 1994.

DUQUE, Gonzaga. [1899] Mocidade morta. Notas e estudo de Adriano da Gama Kury e Alexandre Eulalio. Rio de Janeiro: Fundação Casa de Rui Barbosa, 1995.

LUZ, Fábio. O ideólogo. Rio de Janeiro: Typographia Altina, 1903. Os Emancipados. Lisboa: Livraria Classica Editora, 1906.

MENDONÇA, Curvelo de. Regeneração. Rio de Janeiro: Garnier, 1904.

PEIXOTO, Afrânio. [1911] A esfinge. São Paulo: Clube do Livro, 1987.

MIRANDA, Veiga. Redempção. São Paulo: Empresa Typographica Editora O Pensamento, 1914.

$* * *$

Sobre Anatole France

AHLSTRÖM, Gunnar. "Pequena história" da atribuição do Prêmio Nobel a Anatole France, in FRANCE, A. O crime de Sylvestre Bonnard. Rio de Janeiro: Editora Delta, 1963.

AMAR, Marisol B. "L'utilisation des mots-outils dans le mécanisme de l'ironie, étudiée chez 
Anatole France”. The French Review, nº 6, may 1970, p. 885-890.

BANCQUART, Marie-Claire. "Introduction, notices, notes, variants et bibliographie", in FRANCE, Anatole. Oeuvres I. Paris: Gallimard, 1984.

"Introduction, notices, notes, variants et bibliographie", in

FRANCE, Anatole. Oeuvres II. Paris: Gallimard, 1987.

. "Introduction, notices, notes, variants et bibliographie", in

FRANCE, Anatole. Oeuvres III. Paris: Gallimard, 1991.

. "Introduction, notices, notes, variants et bibliographie", in

FRANCE, Anatole. Oeuvres IV. Paris: Gallimard, 1994.

Anatole France, un sceptique passionné. Paris: Calmann-Lèvy,

1984a.

Anatole France. Paris: Éditions Julliard, 1994a.

FRAGA, Denise. (2007) Um parágrafo de História na Literatura Francesa: a representação do caso Dreyfus em L'Île des Pingouins, de Anatole France. Dissertação (Mestrado em Letras) - Instituto de Biociências, Letras e Ciências Exatas da Universidade Estadual Paulista, São José do Rio Preto, 2007.

REW, Cecil L. "Imaginative Comparisons in the fiction of Anatole France: an attempt at classification". The French Review, vol. 18, n² 2, Dec. 1944, pp. 100-108.

TENDRON, Édith. Anatole France inconnu. Dirigée par Jean-Marie Graitson. Liège: Éditions du Céfal, 1995. Collection "Histoire et critique littéraires". 
Sobre Lima Barreto:

BARBOSA, Francisco de Assis. A vida de Lima Barreto. Rio de Janeiro: Livraria José Olympio Editora, 2012. "Lima Barreto, Precursor do Romance Moderno", in BARRETO, Alfonso Henriques de Lima. Prosa Seleta. Rio de Janeiro: Nova Aguilar, 2006.

A vida de Lima Barreto. Rio de Janeiro: Livraria José Olympio

Editora, 1959.

COUTINHO, Carlos Nelson. "O significado de Lima Barreto na literatura brasileira", in COUTINHO et.ali. Realismo e Anti-Realismo na literatura brasileira. Rio de Janeiro: Paz e Terra, 1974.

FIGUEIREDO, Carmen Lúcia Negreiros. Trincheiras de Sonho: fiç̧ão e cultura em Lima Barreto. Rio de Janeiro: Tempo Brasileiro, 1998.

Lima Barreto e o fim do sonho republicano. Rio de Janeiro: Tempo Brasileiro, 1995.

LIMA, Elizabeth Gonzaga. Avesso de utopias: Os Bruzundangas e Aventuras do doutor Bogóloff. Dissertação (Mestrado em Teoria e História Literária) - Instituto de Estudos da Linguagem, Universidade de Campinas, Campinas, 2001.

LINS, Osman. Lima Barreto e o Espaço Romanesco. São Paulo: Ática, 1976.

OAKLEY, Robert John. Lima Barreto e o destino da literatura. São Paulo: Editora Unesp, 2011.

OLIVEIRA, Irenísia Torres de. "Realismo e Sátira nas Recordações do escrivão Isaías Caminha". Literatura e Sociedade, $\mathrm{n}^{\mathrm{o}}$ 14, 2010, pp. 81-99.

ORNELLAS, Clara Ávila. João Antônio, leitor de Lima Barreto. São Paulo: Editora da Universidade de São Paulo, 2011. Ensaios de Cultura, 44.

PAZ, Ravel Giordano. “Além da Bruzundanga". Revista Cult nº 63, ano VI, 2002, pp.58-61. 
PEREIRA, Lúcia Miguel. (1988) "Lima Barreto", in História da Literatura Braslieira: prosa de ficção, de 1870 a 1920. Belo Horizonte: Itatiaia, 1988.

PRADO, Antonio Arnoni (org). Lima Barreto: uma autobiografia literária. São Paulo: Editora 34, 2012.

. "Prefácio", in BARRETO, Lima. Histórias e Sonhos. São Paulo: WMF Martins Fontes, 2008.

. Trincheiras, Palco e Letras: literatura e utopia no Brasil. São Paulo: Cosac \& Naif, 2004.

. Lima Barreto: o crítico e a crise. São Paulo: Martins Fontes, 1989.

Coleção Leituras.

Lima Barreto: o crítico e a crise. Rio de Janeiro: Livraria Editora

Cátedra, 1976.

ROSSO, Mauro. Lima Barreto e a política: os "contos argelinos" e outros textos recuperados. Rio de Janeiro: ed. PUC-Rio. São Paulo: Ed. Loyola, 2010. 


\section{Bibliografia Geral}

ALMEIDA, Milene Suzano de. Melodrama bacharelesco: um estudo estilístico da recepção do caso Dreyfus no Brasil. Dissertação (Mestrado em Teoria e História Literária) - Instituto de Estudos da Linguagem, Universidade de Campinas, Campinas, 2009.

. “Anatole France no divã". Revista Criação \& Crítica, n ${ }^{\circ} 6$,

2001, p. 84-89.

AUERBACH, Erich "La cour et la ville", AUERBACH, E. Ensaios de literatura Ocidental filologia e crítica. Tradução de Samuel Titan Jr. e José Marcos Mariani de Macedo. São Paulo: Duas Cidades; Ed. 34, 207.

BACRY, Patrick. Les figures de style et autres procédés stylistiques. Paris: Éditions Belin, 1992.

BARTHES, Roland. "O discurso da história”, in BARTHES, R. O rumor da língua. Prefácio Leyla Perrone-Moisés; tradução Mario Laranjeiras. São Paulo: Martins Fontes, 2004.

BERGSON, Henri. Le rire: essai sur la signification du comique. $13^{\text {a }}$ edição. Paris : PUF, 2010.

BERTHIER, Patrick ; JARRETY, Michel (dir.). Histoire de la France littéraire: modernités (XIXe - Xxe siècle). Paris: PUF, 2006.

BILAC, Olavo. Ironia e piedade. Rio de Janeiro: Livraria Franciso Alves, 1916.

BOSSUET, Jacques-Bénigne. Discours sur L'Histoire Universelle. Chronologie et préface par Jacques Truchet. Paris: Garnier-Flammarion, 1966.

BRITO BROCA. A vida literária no Brasil -1900. Rio de Janeiro: Livraria José Olympio Editora, 1960.

BROOKS, Peter. The Melodramatic Imagination: Balzac, Henry James, Melodrama, and 
the Mode of Excess. New Haven/London: Yale University Press, 1995.

BROMBERT, Victor. The Intellectual Hero: studies in the French Novel, 1880-1955. New York: J. B. Lippincot Company, 1961.

BUBER, Martin. O Socialismo Utópico. Tradução de Pola Civelli. São Paulo: Perspectiva, 2007. Coleção Debates, 31.

CAMPOS, Regina Salgado. “Anatole France nos anos 40”, in NITRINI, Sandra (org.). Aquém

e além mar: relações culturais: Brasil e França. São Paulo: Hucitec, 2000. Coleção Linguagem e Cultura, 33 .

CANDIDO, Antonio. O discurso e a cidade. Rio de Janeiro: Ouro sobre azul, 2010. . "A Personagem do Romance", in Candido, Antonio et.al. A Personagem de fiç̧ão. São Paulo: Perspectiva, 2009. Coleção Debates, 1.

. "Radicais de ocasião", in CANDIDO, Antonio. Teresina. Rio de Janeiro:

Ouro sobre Azul, 2007.

"A vida ao rés-do-chão", in CANDIDO, A. et.al. A Crônica: o gênero, sua fixação e suas transformações no Brasil. Campinas, SP: Editora da Unicamp, 1992.

CARELLI, Mario. Culturas cruzadas: intercâmbios culturais entre França e Brasil. São Paulo: Papirus, 1994.

CARVAlho, José Murilo. Cidadania no Brasil: o longo caminho. Rio de Janeiro: Civilização Brasileira, 2009.

Os Bestializados: o Rio de Janeiro e a República que não foi. São Paulo: Companhia das Letras, 1987.

CARONE, Edgard. República Velha II - Evolução Política (1889-1930). São Paulo: Difel, 1979.

CARPENTIER, Jean; LEBRUN, François. Histoire de France. Préface de Jacques Le Goff. Paris: Éditions du Seuil, 2000. 
COMPAGNON, Antoine. "Introduction”, In BOURGET, Paul. Le disciple. Paris: Le Livre de Poche, 2010.

CONRAD, Joseph. [1920] "Crainquebille", in CONRAD, Joseph. Notes on lifes and letters. England: General Books, 2010.

COUTINHO, Eduardo F \& CARVALHAL, Tania F (orgs.). Literatura Comparada: textos fundadores. Rio de Janeiro: Rocco, 2011.

DÉMIER, Francis. La France du XIXe siècle - 1814-1914. Paris: Éditions du Seuil, 2000.

DÉCAUDIN, Michel; LEUWERS, Daniel. Histoire de la littérature française: de Zola à Guillaume Apollinaire (1869-1920). Paris: Flammarion, 1996.

DIMAS, Antônio. Tempos eufóricos : análise da revista Kosmos, 1904-1909. São Paulo: Ática, 1983. Coleção Ensaios, 88.

DU CAMP, Maxime. Souvenirs littéraires: Flaubert, Fromentin, Gautier, Musset, Sand. Bruxèlle: Éditions Complexe, 2002.

ECO, Umberto. Seis passeios pelos bosques da ficção.Tradução Hildegard Feist. São Paulo: Companhia das Letras, 1994.

EIKHENBAUM, et. al. (1971) Teoria da literatura: textos dos formalistas russos. Tradução de Ana Mariza Ribeiro, Maria Aparecida Pereira, Regina Zilberman, Anônio Carlos Hohlfedt, prefácio de Boris Schnaiderman. Porto Alegre: Ed. Globo, 1971.

FAUSTO, Boris. História do Brasil. São Paulo: Edusp, 2003.

FRYE, Northrop. Anatomy of Criticism : four essays. Foreword by Harold Bloom. $10^{\text {th }}$ edition. New Jersey : Princeton University Press, 1990.

GENETTE, Gérad. Palimpsestes: la littérature au second degré. Paris: Éditions du Seuil, 1982.

GLEDSON, John. Influências e impasses: Drummond e alguns contemporâneos. Tradução de Frederico Dentello. São Paulo: Companhia das Letras, 2003. 
HOLANDA, Sérgio Buarque. "Em torno de Lima Barreto", in HOLANDA, Sérgio Buarque. Cobra de Vidro. São Paulo: Perspectiva, 2012. Coleção Debates, 156.

HUTCHEON, Linda. "Ironie, satire, parodie: une approche pragmatique de l'ironie". Poetique 46, 1981.

KNIGHT, Charles. "Introduction: the satiric frame of mind", in KNIGHT, C. The literature of satire. Cambridge: Cambridge University Press, 2004.

LIMA, Luiz Costa (coord.). A Literatura e o leitor: textos de estética da recepção. Rio de Janeiro: Paz e Terra, 2002.

LINS, Vera. Novos pierrôs, velhos saltimbancos: os escritos de Gonzaga Duque e o final do século XIX carioca. Curitiba: Secretaria de Estado da Cultura: Câmara Brasileira do livro: The Document Company - Xerox do Brasil, 1997.

LUKÁCS, Georg. "A questão da sátira”, in Arte e sociedade: escritos estéticos 1932-1967. Organização, apresentação e tradução Carlos Nelson Coutinho. Rio de Janeiro: Editora UFRJ, 2011. Coleção Pensamento Crítico, 13.

- A Teoria do Romance. Tradução de José Marcus Mariani de Macedo. São Paulo: Duas Cidades; Ed. 34, 2000.

The Historical Novel. Introduction by Fredric Jameson. Lincoln and London: University of Nebraska Press, 1983.

MACHADO NETO, Antonio Luis. Estrutura Social da República das Letras: Sociologia da Vida Intelectual Brasileira - 1870-1930. São Paulo: Edusp, 1973.

MEYER, Augusto. Prêto\& Branco. Rio de Janeiro: Instituto Nacional do Livro, 1956.

MICELI, Sergio. Poder, Sexo e Letras na República Velha (estudo clínico dos anatolianos). São Paulo: Editora Perspectiva, 1977. Coleção Elos

NEEDELL, Jeffrey D. Belle Époque tropical: sociedade e cultura de elite no Rio de Janeiro na virada do século. Tradução de Celso Nogueira. São Paulo: Companhia das Letras, 1993. 
NOBRE, Marcos. “Depois da “formação", in Revista Piauí 74, ano 7, novembro de 2012.

NORDMANN, Jean-Thomas. La critique littéraire françaixe au XIXe siècle (1800-1914). Paris: Libraire Générale Française, 2001.

OLIVEIRA, Diogo de Castro. Onosarquistas e patafísicos: a boemia literária no Rio de Janeiro fin-de-siècle. Rio de Janeiro: 7Letras, 2008.

PERRONE-MOISÉS, Leyla. "Galofilia e galofobia na cultura brasileira", in PERRONEMOISÉS, Leyla. Vira e mexe, nacionalismo: paradoxos no naturalismo literário. São Paulo:Companhia das Letras, 2007.

PROPP, Vladímir. Comicidade e riso. Tradução de Aurora Bernardini e Homero Freitas de Andrade. São Paulo: Editora Ática, 1992.

REIK, Theodor. The secret self: psychoanalytic experiences in life and literature. New York: Farrar, Straus and Young, 1953.

RIVAS, Pierre. Encontro entre literaturas: França-Brasil-Portugal. São Paulo: Editora Hucitec, 1995.

ROSENFELD, Anatol. "Reflexões sobre o romance moderno", in ROSENFELD, Anatol. Texto/Contexto I. São Paulo: Editora Perspectiva, 1996. Coleção Debates, 7.

SANTOS, Milton. A urbanização brasileira. São Paulo: Editora da Universidade de São Paulo, 2008.

SCHOENTJES, Pierre. Poétique de l'ironie. Paris: Éditions du Seuil, 2001.

SCHWARZ, Roberto. Ao vencedor as batatas - forma literária e processo social nos inícios do romance brasileiro. São Paulo: Ed. 34, 2000.

SEVCENKO, Nicolau. A Revolta da Vacina: mentes insanas em corpos rebeldes. São Paulo: Cosac Naify, 2010.

- Literatura como missão: tensões sociais e criação cultural na Primeira República. São Paulo: Companhia das Letras, 2003. 
SIMPSON, Paul. On the discourse of satire : toward a stylistic model of satirical humour. Philadelphia: John Benjamins, 2003.

TADIÉ, Jean-Yves. La littérature française: dynamique \& histoire II. Paris : Éditions Gallimard, 2007.

THIBAUDET, Albert. Histoire de la literature française. Paris: CNRS Éditions, 2007. Réflexions sur la littérature. Paris: Edition Gallimard, 2007a.

TOLSTOI, Comte Léon. Qu'est-ce que l'Art?. Traduit du russe et précédé d'une Introduction para Teodor Wyzewa. Paris : Librairie Académique, 1918.

TOLSTOI, Liev. Os últimos dias. São Paulo: Penguin Classics Companhia das Letras, 2011.

WILLIAMS, Raymond. O campo e a cidade: na história e na literatura. Tradução de Paulo Henriques Britto. São Paulo: Companhia das Letras, 2001.

WINOCK, Michel (org.). L'affaire Dreyfus. Paris: Ed. Seuil, 1998.

La fièvre hexagonale - les grandes crises politiques de 1871 à 1968.

Paris: Éditions du Seuil, 2009. 